ECOLOGICAL STUDIES ON MARINE ALGAL-DWELLING COPEPODA (HARPACTICOIDA) FROM WELLINGTON, NEW ZEALAND.

Geoffrey Richard Frederick

HICKS

Submitted for the degree of Doctor of Philosophy in Zoology at the Victoria University of Wellington, September 1976 . 
A quantitative seasonal study has been made on aspects of the ecology of marine algal-dwelling harpacticoid copepods at Island Bay, Wellington, New Zealand. Results are based on 154 samples collected from six species of macro-algae between April 1973 and March 1974 and is the first integrated research programme into the population dynamics of members of the phytal meiobenthos. Harpacticoid species collected are listed and brief taxonomic and zoogeographic notes on selected species is given. An analysis is made of the southern hemisphere zoogeographic relationships of the N.Z. marine harpacticoid fauna and this suggests distinct affinities with the Magellanic region of South America. The numerical contribution of harpacticoids to the total phytal meiofauna shows them to be the dominant taxon. Density comparisons are made with parallel studies on the sediment meiobenthos; in general the phytal is comparable with those from sandy bottoms. Species occurrence on each algal substrate, their specific association between each seaweed and within the rocky shore algal biotope as a whole is assessed. Seasonal periodicity in population density is variable and is dependent on the reproductive activity of individual species. Breeding data are analysed for twenty species and reveal continuous or protracted breeding seasons, providing useful comparisons with interstitial and epibenthic representatives. Substrate preference for particular algae by truly phytal-dwelling harpacticoids is demonstrated for the first time. 
TABLE OF CONTENTS

Page

GENERAL INTRODUCTION

PAPER 1

Ecological studies on marine algal-dwelling

Copepoda (Harpacticoida). 1. Species

composition and zoogeography; contribution

to total seaweed meiofauna.

ABSTRACT

INTRODUCTION

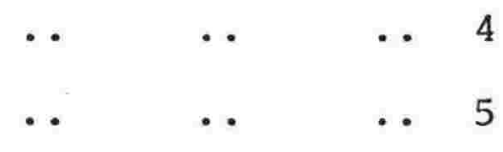

THE STUDY AREA

Climate

Hydrography

Geology

.

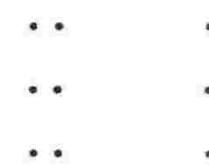

$\begin{array}{rrrr}\ldots & \ldots & \ldots & 6 \\ \ldots & \ldots & \ldots & 7 \\ \ldots & \ldots & \ldots & 10\end{array}$

Zonation of the Important Benthic Macrophytes at the Study Area

..

Seasonal Changes in Algal Growth Characteristics

SAMPLING
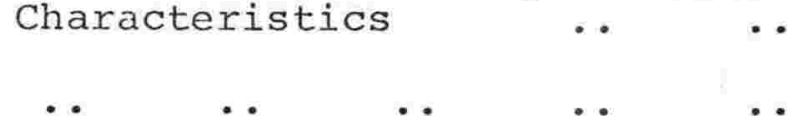

. 15

SORTING

ENVIRONMENTAL VARIABLES AT THE STUDY SITE

Tidal Range \& Water Movements ..

Temperature

.. 20

Salinity

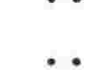

Wind \& State of Sea

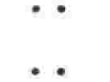

.. 22

Particle Size

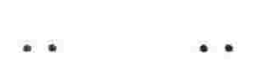

.. 24

Algal Surface-Area Determination

.. 24

.. 27

THE HARPACTICOID FAUNA

Species Composition

Systematic and Zoogeographic Notes on

Selected Species

zoogeography

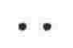

-

.
.. 32

.. 43 
DISCUSSION

Relationship of Harpacticoid Fauna to Algae .. 52

Contribution of Harpacticoids to Total Algal

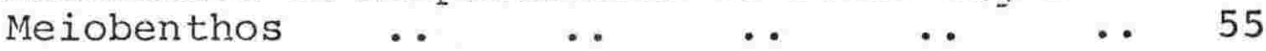

Comparison with Level-Bottom Meiobenthos .. 58

$\begin{array}{llllllllll}\text { ACKNOWLEDGEMENTS } & \ldots & \ldots & \ldots & \ldots & \ldots & \ldots & \ldots & 62\end{array}$

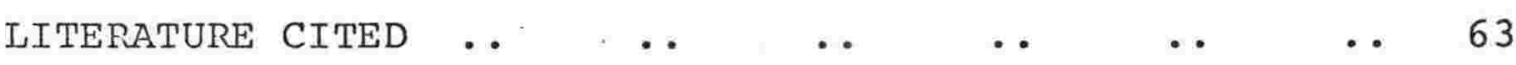

PAPER 2

Ecological studies on marine algal-dwelling Copepoda (Harpacticoida). 2. Seasonal changes in population density; species occurrence and associations.

ABSTRACT

INTRODUCrIION

METHODS

RESULTS
74

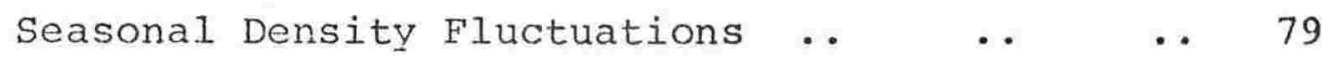

a). Enteromorpha intestinalis assemblage .. 79

b). Corallina officinalis assemblage $\quad \ldots \quad 83$

c). Zonaria turneriana assemblage .. $\quad$. 92

d). Xiphophora chondrophylla assemblage .. 95

e). Pterocladia lucida assemblage $\quad \ldots \quad$. . 999

f). Ecklonia radiata assemblage $\quad \ldots \quad \ldots 103$

$\begin{array}{lllllll}\text { Species Dominance } & \ldots & \ldots & \ldots & \ldots & & \ldots\end{array}$

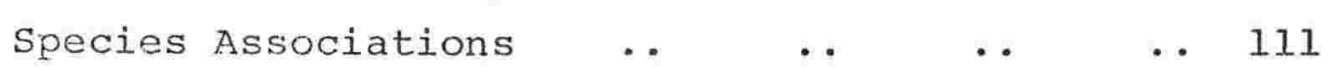

DISCUSSION

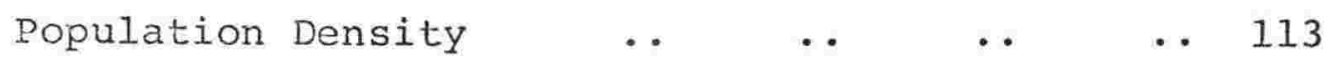

Species Association and Assemblage

$\begin{array}{llllll}\text { Characterisation } & \ldots & \ldots & \ldots & \ldots & 117\end{array}$

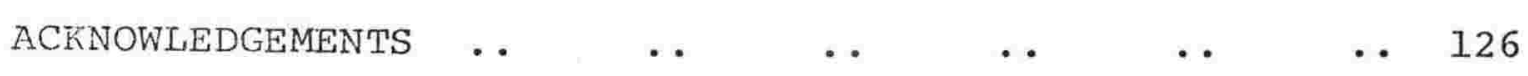

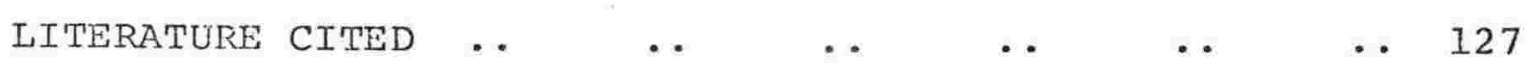


PAPER 3

Ecological studies on marine algal-dwelling

Copepoda (Harpacticoida). 3. Breeding Activity

ABSTRACT

INTRODUCTION

METHODS

RESULTS

Breeding Activity

Egg Number - Length Relationship
.. 131

. 132

. 134

. 136

.. 168

DISCUSSION

Generalized Pattern of Breeding Activity _. 170

Extrinsic Determinants $\quad \ldots \quad \ldots \quad \ldots \quad \ldots \quad \ldots \quad \ldots 176$

a). Effect of Temperature $\quad \ldots \quad \ldots \quad \ldots 176$

b). Influence of Food Supply $\quad \ldots .177$

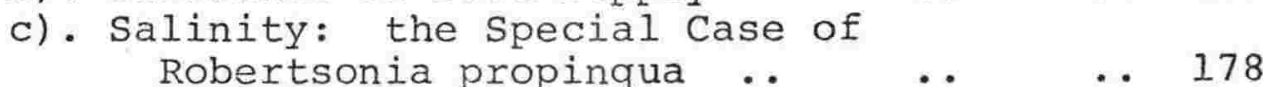

Intrinsic Determinants $\quad \ldots \quad \ldots \quad \ldots \quad \ldots \quad \ldots 180$

a). Sex Ratio \& Population Density $\quad \ldots \quad \ldots 180$

b). Interspecific Competition $\quad \ldots \quad \ldots 181$

Life Cycle of porcellidium dilatatum .. . . 182

Concluding Remarks $\quad \ldots \quad \ldots \quad \ldots \quad \ldots 183$

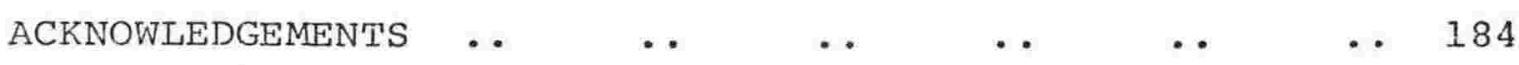

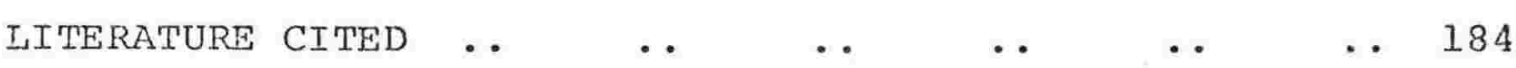

$\underline{\text { PAPER } 4}$

Substrate preference of marine algal-dwelling

Copepoda (Harpacticoida).

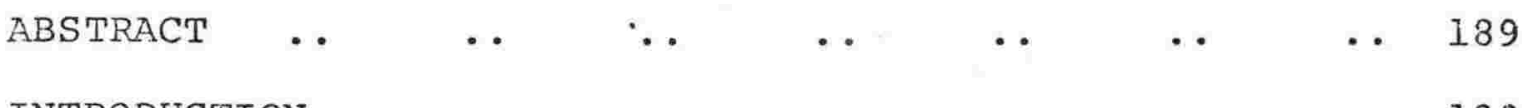

$\begin{array}{llllllll}\text { INTRODUCTION } & \ldots & \ldots & \ldots & \ldots & \ldots & \ldots & 190\end{array}$

MATERIALS AND METHODS

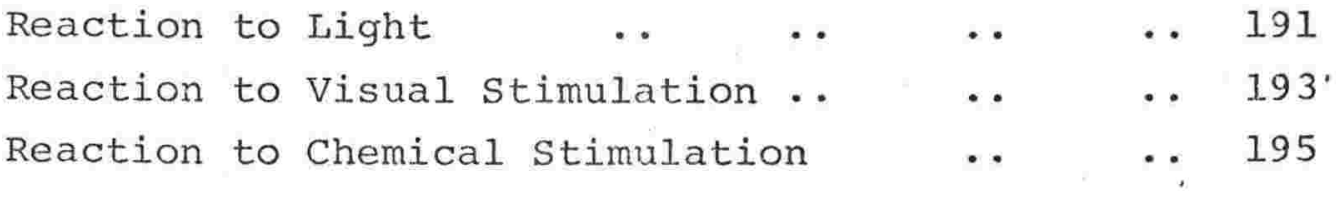


RESULTS

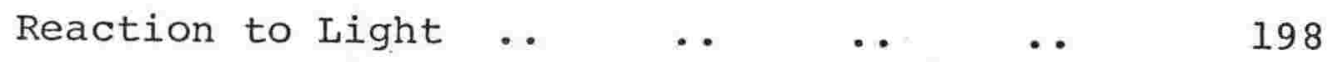

Reaction to Visual stimulation .. .. 200

Reaction to Chemical Stimulation .. ... 200

Effects of Seaweed Treatment .. ... 200

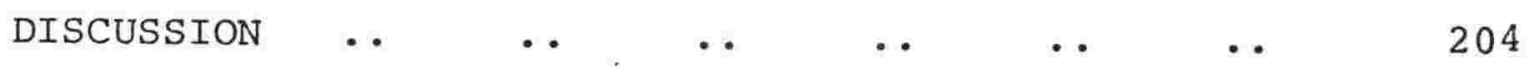

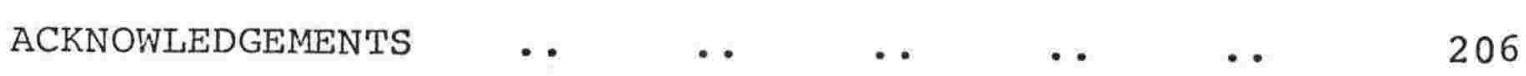

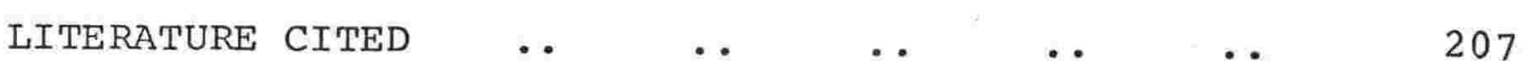

\section{APPENDIX}

Reprint: "Neopeltopsis pectinipes, a new genus and species of seaweed-dwelling copepod (Harpacticoida: Peltidiidae) from Wellington, New Zealand.: N.Z. Journal of Marine and Freshwater Research 10: 363-370 (1976).

THESIS ACKNOWLEDGEMENTS 
FIG. I - Sketch map of the study area on the south Wellington coast ... ..

FIG. 2 - Seasonal variation in air and seawater temperature during the study period

FIG. 3 - Seasonal variation in rainfall and seawater salinity during the study period .. $\quad$.. $\quad$..

FIG. 4 - Seasonal variation in wind strength and state of the sea during the study period $\quad$. $\quad \ldots \quad$..

FIG. 5 - Cumulative curve of Corallina sandy sediments .. $\ldots$.

FIG. 6 - Weight of surface film plotted against surface area of polythene standard, with fitted regression line

FIG. 7 - Southern hemisphere zoogeographic relationships of the New Zealand marine Copepoda (Harpacticoida)

FIG. 8 - Matrix of affinity of harpacticoid fauna from the six algae studied

FIG. 1 - Seasonal variation in population density of the harpacticoids associated with the alsa Enteromorpha intestinalis $\quad \ldots \quad \ldots$

FIG. 2 - Seasonal variation in population density of the harpacticoids associated with the alga Corallina officinalis $\quad \ldots \quad \ldots$

FIG. 3 - Seasonal variation in population density of the harpacticoids associated with the alga Corallina officinalis $\quad \ldots \quad \ldots$

FIG. 4 - Seasonal variation in population density of the harpacticoids associated with the alga Corallina officinalis $\quad$. $\quad \ldots \quad \ldots$ 
FIG. 5 - Seasonal variation in population density of harpacticoids associated with the alga Zonaria turneriana $\quad$.. $\quad$..

FIG. 6 - Seasonal variation in population density of the harpacticoids associated with the alga Xiphophora chondrophylla

FIG. 7 - Seasonal variation in population density of the harpacticoids associated with the alga Pterocladia lucida $\quad$.. $\quad$..

FIG. 8 - Seasonal variation in population density of the harpacticoids associated with the alga Ecklonia radiata

FIG. 9 - The association of harpacticoid species in the algal biotope at Island Bay, Wellington

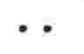

-.

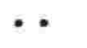

\section{PAPER 3}

FIG. 1 - Seasonal breeding pattern of Ectinosoma australe on the alga Corallina officinalis $\ldots$..

FJG. 2 - Seasonal breeding pattern of Harpacticus pulvinatus on the alga Pterocladia $\begin{array}{lllllllll}\text { lucida } & \cdots & \ldots & \ldots & \ldots & \ldots\end{array}$

FIG. 3 - Seasonal breeding pattern of Zausopsis mirabilis on the alga zonaria turneriana

FIG. 4 - Seasonal breeding pattern of Tisbe holothuriae on the alga Enteromorpha intestinalis $\ldots . \quad \ldots$.. .

FIG. 5 - Seasonal breeding pattern of Scutellidium spinatum on the alga Corallina officinalis $\quad \ldots \quad \ldots \quad \ldots \quad \ldots$

FIG. 6 - Seasonal breeding pattern of Porcellidium dilatatum on the alga Zonaria turneriana

FIG. 7 - Percentage occurrence of males in the population of $\underline{P}$. dilatatum and $\underline{A}$. cinctus

FIG. 8 - Seasonal breeding pattern of Porcellidium erythrum on the alga Xiphophora chondrophylla $\quad \ldots \quad \ldots \quad \ldots \quad \ldots$

FIG. 9 - Seasonal breeding pattern of Alteutha littoralis on the alga pterocladia lucida 
FIG. 10 - Seasonal breeding pattern of Eupelte regalis on the alga Corallina

officinalis ... ..

FIG. 11 - Seasonal breeding pattern of Neopeltopsis pectinipes on the alga Pterocladia lucida ... ..

FIG. 12 - Seasonal breeding pattern of Paradactylopodia brevicornis on the alga Corallina officinalis..

FIG. 13 - Seasonal breeding pattern of Amphiascopsis cinctus on the alga Corallina officinalis

FIG. 14 - Seasonal breeding pattern of Amonardia perturbata on the alga Corallina officinalis $\quad \ldots \quad \ldots$..

FIG. 15 - Seasonal breeding pattern of Robertsonia propinqua on the alga Enteromorpha intestinalis ..

FIG. 16 - Seasonal breeding pattern of Mesochra flava on the alga Enteromorpha intestinalis .. $\ldots$

FIG. 17 - Seasonal breeding pattern of Orthopsyllus linearis on the alga Corallina officinalis

FIG. 18 - Seasonal breeding pattern of Laophonte cornuta on the alga Zonaria turneriana

FIG. 19 - Seasonal breeding pattern of Laophonte cornuta var. nigrocincta on the alga Corallina officinalis - .

FIG. 20 - Seasonal breeding pattern of Paralaophonte meinerti on the alga Corallina officinalis

FIG. 21 - Seasonal breeding pattern of Lourinia armata on the alga Corallina officinalis ... ...

FIG. 22 - Calendar of reproductive activity of twenty algal-dwelling copepod species

FIG. 23 - Relationship of mean egg number per female to the mean percentage of ovigerous females of each species 
FIG. 1 - Light/dark tube for testing phototactic

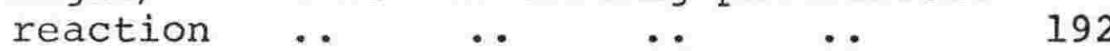

FIG. 2 - Aquarium for testing the visual reaction of copepods to seaweeds .. $\quad$.. 194

FIG. 3 - Y-maze for testing chemical attraction of copepods for seaweeds .. $\quad$.. 197

FIG. 4 - Distribution of porcellidium dilatatum in experimental arena of visual apparatus 


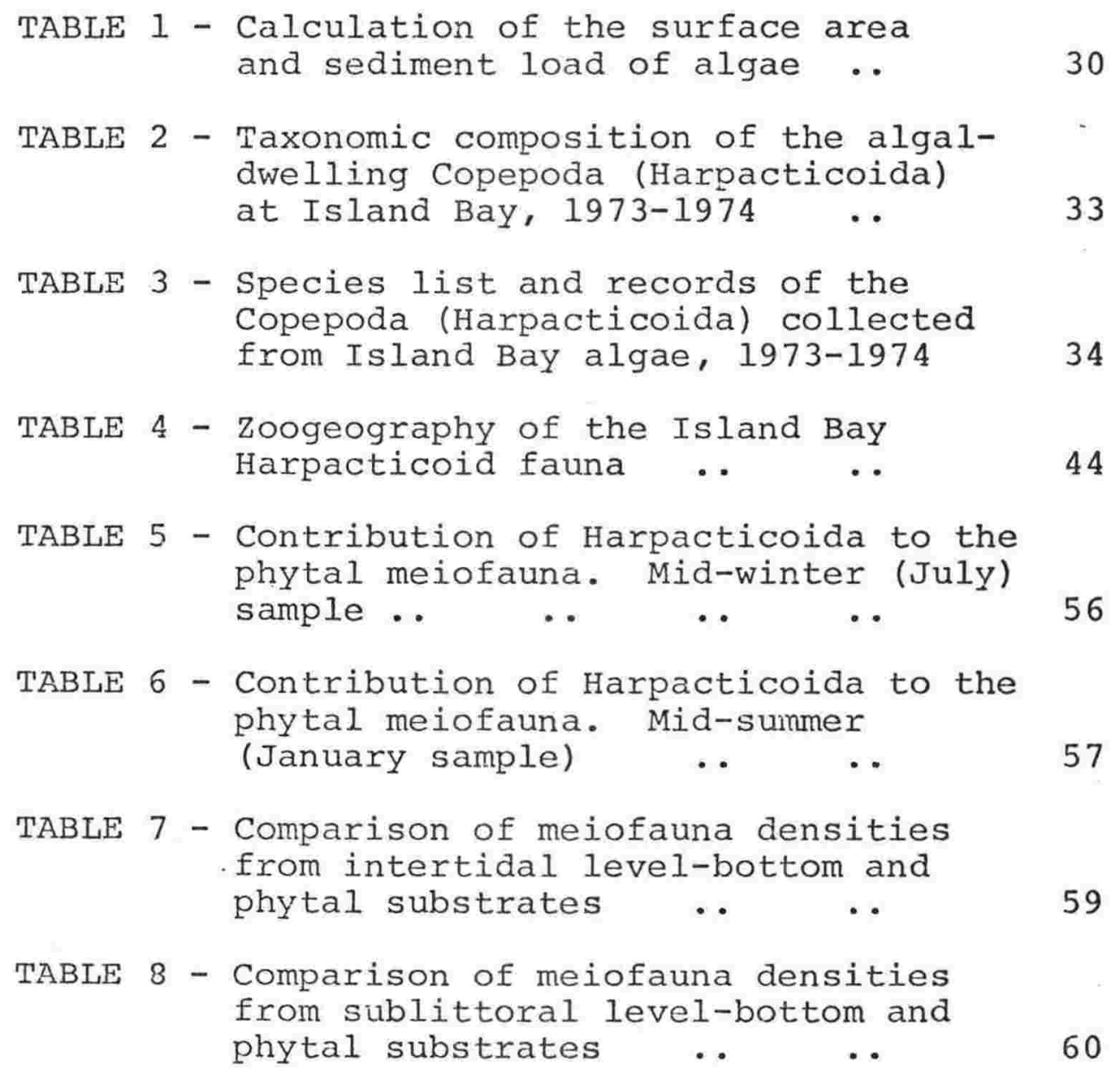

TABLE 2 - Taxonomic composition of the algaldwelling Copepoda (Harpacticoida) at Island Bay, 1973-1974 ..

TABLE 3 - Species list and records of the Copepoda (Harpacticoida) collected from Island Bay algae, 1973-1974

TABLE 4 - Zoogeography of the Island Bay Harpacticoid fauna .. ..

TABLE 5 - Contribution of Harpacticoida to the phytal meiofauna. Mid-winter (July) sample .. .. .. ..

TABLE 6 - Contribution of Harpacticoida to the phytal meiofauna. Mid-summer (January sample) . . .

TABLE 7 - Comparison of meiofauna densities from intertidal level-bottom and phytal substrates $\quad \ldots$...

TABLE 8 - Comparison of meiofauna densities from sublittoral level-bottom and phytal substrates

TABLE 1 - Seasonal percentage composition of harpacticoids on Enteromorpha

TABLE 2 - Seasonal percentage composition of harpacticoids on Corallina ..

TABLE 3 - Seasonal percentage composition of harpacticoids on Zonaria ..

TABLE 4 - Seasonal percentage composition of harpacticoids on Xiphophora ..

TABLE 5 - Seasonal percentage composition of harpacticoids on Pterocladia

TABLE 6 - Seasonal percentage composition of harpacticoids on EckIonia .. 
TABLE 7 - Species occurrence and actual numbers of the Island Bay algal-dwelling Harpacticoida

TABLE 8 - Dominance ranking and frequency of occurrence of the important species from each alga $\quad . . \quad$.. $\quad$..

TABLE 9 - Succession in peaks of maximum population density on Corallina

TABLE 10 -Comparison of phytal parallel assemblages $\quad$.. $\quad \ldots$..

TABLE 11 - Comparison of 'coralline sand' parallel assemblages .. . .

\section{$\underline{\text { PAPER } 3}$}

TABLE 1 - Annual mean percentage of ovigerous females, annual mean number of eggs carried by ovigerous females and reproductive capacities .. ..

PAPER 4

TABLE 1 -. Selection tube: choice of light or dark $\ldots$..

TABLE 2 - Choice in experimental area of optical chamber... .. ..

TABLE 3 - Chemical attraction in 'Y'-tube of Scutellidium armatum and Porcellidium dilatatum .. ..

TABLE 4 - Effect of physical and chemical treatment on weed selection .. 
In 1969 whilst a second year zoology student, I was introduced to the rich marine algal flora of Cook strait and to the potential of this biotope in providing a substrate for a large number of sessile and mobile organisms. A preliminary study of what proved to be a remarkably diverse and abundant fauna associated with littoral coralline algae ensued and revealed marine representatives of 12 different phyla (Hicks 1971a). I then developed a special interest in the microarthropods of these algae, and during summer vacation employment with the New Zealand Oceanographic Institute (D.S.I.R.), taxonomic descriptions of a number of new harpacticoid copepods were completed (Hicks 197lb). Once established, my interest to continue research on algal - dwelling harpacticoids evolved into the present thesis.

Systematic research on New Zealand non-planktonic marine Copepoda is an almost unexplored field. Since the first N.Z. recordings of these animals by George M. Thomson F.L.S in 1878, descriptions of only about 54 species have appeared in the literature. With 65 species and 1 variety dealt with in this study, knowledge of the species composition of the N.Z. harpacticoid fauna is now expanding. In the early stages of this thesis jt was intended to work toward an analysis of community structure and dynamics of phytal meiobenthos. However, faced with numerous taxonomic problems and the time involved in resolving these, a more fundamental approach to the ecology of the dominart harpacticoid species was undertaken. The aims of the thesis then became: 
1) to provide a comprehensive list of the species collected and an attempt at explaining their zoogeographic position in relation to the other southern hemisphere landmasses and

2) to outline the seasonal and successive periodicity in population density; evaluate the occurrence and associations of harpacticoids between algal substrates and within the algal biotope as a whole. Noticeable seasonal fluctuations in population density prompted an analysis of reproductive activity to heip assess its influence on observed density variations. Furthermore, apparent species localisations on particular algae led to an experimental analysis of substrate selection.

In this approach, which is probably the first such quantitative seasonal study dealing exclusively with phytal harpacticoids, one is constantly required to "bridge the information gap" with the more well researched level - bottom sediment meiofauna. In this way a rationalisation may be made of the part played by phytal dwellers, and in particular the harpacticoid component, within the coastal marine ecosystem.

With over $26 \%$ of the fauna included in this work remaining as undescribed species, future research direction is clearly one of a comprehensive taxonomic review. As noted in paper 1 (page 32) revisions are now underway in collaboration with an Australian worker.

FORMAT OF THE THESIS

This thesis is an integration of four distinct manuscripts each intended for separate publication. 
Papers one, two and three meet all publication

requirements of the N.Z. Journal of Marine and Freshwater Research, while paper four fulfills the conditions for publication in Marine Biology. Text references to Hicks (in press $a, b$, or $c$ ) is to avoid unnecessary alteration to galley proofs and serves also as reference to the appropriate section in the thesis.

\section{LITERATURE CITED}

HICKS, G.R.F. 197la: Checklist and ecological notes on the fauna associated with some littoral corallinacean algae. Bulletin of Natural Sciences Victoria University of Wellington Biological Society 2: 47-58.

1971b: Some littoral harpacticoid copepods, including five new species, from wellington, New Zealand, N.Z. Journal of Marine and Freshwater Research 5: 86-119.

THOMSON, G.M. 1878 (1879): On the New Zealand Entomostraca. Transactions and Proceedings of the New Zealand Institute 11: 251-263. 
PAPER 1

ECOLOGICAL STUDIES ON MARINE ALGAL-DWELLING COPEPODA

(Harpacticoida). 1. SPECIES COMPOSITION AND ZOOGEOGRAPHY; CONTRIBUTION TO TOTAL SEAWEED MEIOFAUNA.

pages: 4-73 
ECOLOGICAL STUDIES ON MARINE ALGAL-DWEILING COPEPODA (HARPACTICOIDA). 1. SPECIES COMPOSITION AND ZOOGEOGRAPHY; CONTPIBUTION TO TOTAL, SEAWEED HEIOFAUNA.

\section{GEOFFREY R.F. HICKS}

Zoology Department, Victoria University of Wellington, Private Bag, Wellington, New Zealana.

\section{ABSTRACT}

A quantitative seasonal investigation of the harpacticoid copepods present in the aufwuchs assemblages of six marine macrophytes was carried out at Island Bay, Wellington, New Zealand between April 1973 and March 1974. In this paper, which is the first, the characteristics of the physical environment are outlined and included is an account of the shore zonation patterns of the dominant marine vegetation. Sampling and sorting methodology is described and a method of determining the relative surface area of algae by way of surface active agents is presented.

An analysis of the harpacticoid species composition and their zoogeography is made from the 154 samples collected. Sixty-six species and one variety from 16 famjijes are identified and includes 9 new distribution records for the southern hemisphere and 30 for New Zealana. The zoogeographic relationships of the N.Z. Harpacticoica are very clearly with the Magellanic or southern South American region, while a low specific affinity exists with other southern remisphere continents. The present data support plate tectonics as the mechanism largely responsible for the present distribution of the austral harpacticoid fauna. 
Calculation of the between algae faunal association indicates a relationship between copepods and the physiognomic structure and sediment trapping potential of the algae. Harpacticoid copepods constitute the numerically dominant taxon of the phytal meiobenthos with ostracods and nematodes next in abundance. The density of midlittoral phytal-dwelling harpacticoids ranks with intertidal sandy sediments while sublittoral densities are lower, a trend consistent with that found in other sublittoral marine biotopes.

\section{INTRODUCTION}

The composition and ecology of marine algal-dwelling invertebrates has received significant although only periodic attention during the past forty years (see Moore 1973 for extensive review). Dynamics of the associated macrofauna populations have been the subject of particular investigation but in spite of Dahl's (1948) pioneering work on the smaller arthropod fauna, little has been accomplished relating specifically to meiofaunal taxa. It is only within the last decade that an increased impetus in research on sediment meiobenthos has prompted similar analyses of algal-dwelling populations (e.g. Ohm 1964, Hagerman 1966, Kikuchi 1967, Mukai 1971, Pallares \& Hall 1974a, b).

In the present study, aspects of the ecology of harpacticoid copepods present in the aufwuchs assemblages of marine macrophytes are compared with the now well-researched sediment-dwelling forms. Quantitative samples of marine algae were collected regularly throughout a 12 month period, with the object of gaining seasonal data on species composition and population dynamics of the associated harpacticoid fauna. 
In this first paper the study area, algal biotope and sampling methodology is described from which an analysis of the species composition and zoogeography of the resident harpacticoids has been made. The numerical contribution of phytal copepods to the total seaweed meiofauna is assessed and compared with parallel studies on the sediment meiobenthos. Although valuable comparative material can be extracted from the growing literature on level-bottom copepod assemblages, few direct comparisons can be made with studies dealing exclusively with the seasonal ecology of phytal harpacticoids. From the field collections data were accumulated on the species occurrence and associations, dominance and seasonal changes in population density, reproductive activity of dominant species and the substrate preference of selected copepod species. These results are presented elsewhere (Hicks in press $a, b, c)$.

\section{THE STUDY AREA}

The sampling area is located at Island Bay $\left(41^{\circ} 21.01\right.$ 's; $\left.174^{\circ} 45.88^{\prime} \mathrm{E}\right)$ on the southward facing exposed rocky coast of Cook strait, Wellington, (Fig. 1).

\section{CLIMATE}

The climate of Wellington is characterised by its windiness and lack of extreme seasonal temperatures, primarily due to its close proximity to the sea (Gabites 1960). Wellington is thus typical of a climatically equable temperate region. Kidson (1931) shows the Wellington area to be in the $12.2-12.8^{\circ} \mathrm{C}$ annual sea-level air isotherm with a low annual variability of temperature. Rainfall data indicate 
February and March as the driest months while July is normally the wettest (Seelye 1940). Prevailing wind directions are from the north-west and except for Foveaux strait the cook Strait region boasts the highest annual frequency of gales per year than any other area of New zealand (Watts 1947). High winds and frequency of gales from both the south and north-west have a profound effect on tidal height variations, exposure and turbulence, degree of siltation and on the distribution and abundance of much of the resident biota.

\section{HYDROGRAPHY}

"The land mass of New Zealand is set athwart what would otherwise be a zonal eastwards flow (with the West Wina Drift and the Trade wind Drift lying well to the south and north respectively of New Zealand)" (Bartle 1974:139), and Knox (1950) recognises a transitional overlapping fauna typical of this 'Cookian Province" with a biota showing varying degrees of northern warm water and southern cold water influence. Differences in tidal height and the interaction of derivative water bodies from these two major oceanic systems are largely responsible for the hydrographic environment of cook strait.

The study area lies in a zone of cold temperate mixed water which is variably influenced by surface water movements caused by wind, upwelling, tide, etc. Recent reviews of the area by Heath (1973) and Bartle (1974) outline the major hydrographic features of the area and only a summary is necessary here. 
FIG. 1 - Sketch map of the study area on the south Wellington coast. Inset map shows sampling positions of $A$ : Supralittoral pools; B: Midlittoral pools and C: Sublittoral stations. 


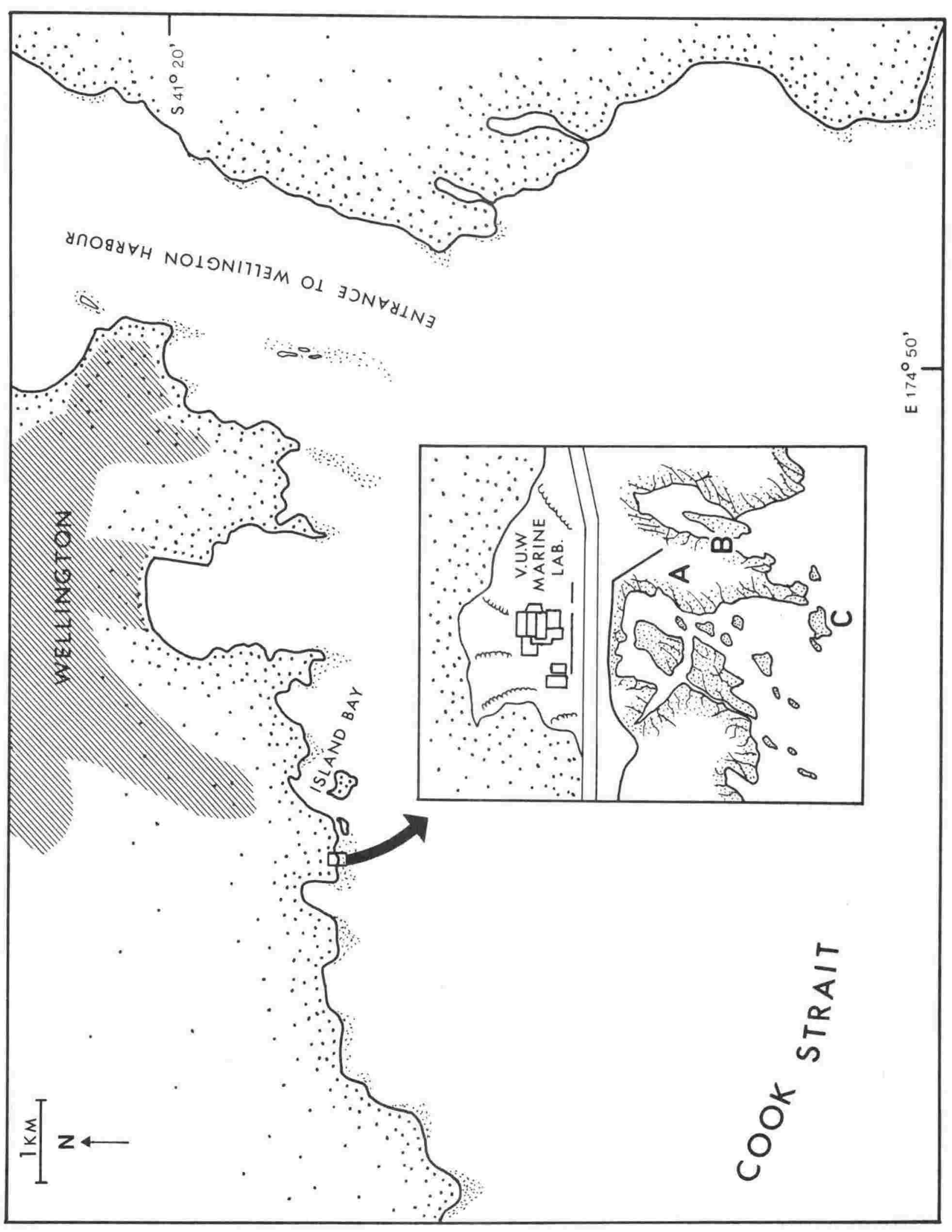


Mixed subtropical and colder subantarctic water flows through eastern cook strait as the cool Southland Current (Heath 1971, 1972) and continues northwards along the Wairarapa coast to meet the East Cape Current, a warm watermass derived from the Trade wind Drift to the north. The western end of cook strait is jnfluenced primarily by the eastward flowing D'Urville Current which is a branch of the warm, saline Westland Current derived from the eastward flowing Tasman Current. These two major current systems meet in the Cook strait Narrows and produce a recognisable convergence (Bartle 1974). Periodic warm tongues of surface and subsurface water associated with the south flowing East Cape Current extend into the deep Cook strait and Kaikoura Canyons and upwell close to the shore, influencing the composition and abundance of local phyto- and zooplankton communities (Bartle 1972, Bradford 1972).

Tidal currents are strong and variable (Olsson 1955, Gilmour 1960) and result from the difference in tidal height at either end of the strait (Heath 1973). The ranges of the neap tides between high and low water are small and vary at different points on the coast, but are between $0.6-1.2 \mathrm{~m}$.

The annual range of surface temperatures in S.E. Cook Strait is about $10.6-13.9^{\circ} \mathrm{C}$ (Gilmour 1960), while inshore temperatures at Island Bay Marine Laboratory recorded by Ritchie (1970) are within the annual range of $10.6-16.5^{\circ} \mathrm{C}$. Surface salinity recordings commonly lie within the range $34.5-35.0 \%$ (Gilnour 1960, Heath 1971). 
GEOLOGY

The rocky shore forms part of the Sinclair Formation, a $4573 \mathrm{~m}$ thick section of presumed Triassic greywackes and argillites (Brodie 1953). This mass of thick, nearly unfossiliferous, indurated sediments constitute the axial chain of New Zealand. The sediments are steeply dipping to the west and the alternating greywacke and argillite strata have become deeply weathered and discoloured due to salt and wave action. Where the rock is shattered and re-cemented with minute quartz veins it is light grey; where affected by weathering joint systems have become more prominent and colour grades to light brown. The more resistant argillite appears as dark bands which in places have the surrounding less consolidated greywackes eroded away. In such cases there exists an ideal environment for the development of the numerous splash-zone and intertidal rock-pools which abound in the area. Rocky profiles are varied, so that exposure to wave action may change considerably within small areas.

ZONATION OF THE IMPORTANT BENTHIC MACROPHYTES AT THE STUDY AREA

In this area the shore classification of Rasmussen (see Jansen 1971) corresponds to a Class II exposed shore, characterised by exposure to heavy wave action at low tidal levels during the full tidal cycle and at high levels oniy during high tide. A generalised account of the intertidal and shallow sublittoral seaweed associations in the area exists in Morton \& Miller (1968) and a detailed annotated checklist of the algal flora can be found in Adams (1972). 
The present account is not intended to be comprehensive and describes only the communities in rock pools and upward facing or slightly sloping sublittoral surfaces from which algae were collected during the sampling programme and is based on $2 \frac{1}{2}$ years of SCUBA diving cbservations.

Algae dominate both horizontal and vertical faces but are reduced or absent from overhangs and crevices, small rhodophytes and corallines being restricted to these areas. Where appropriate depth measurements are in relation to mean low water neap tides.

\section{Supralittoral Pools}

The high shore pool vegetation of the study area consists exclusively of Enteromorpha intestinalis (L.) Greville, which clogs the pools during spring periods of maximum growth. A second branched species of Enteromorpha exists as a dense mat below the level of floating $\mathrm{E}$. intestinalis and resists summer desiccation and bleaching.

\section{Midittoral Pools}

A dense carpet of coralline 'turf' consisting exclusively of Corallina officinalis L. is typical of the midlittoral at the study area. Other macrophytes often associated with Corallina are Hormosira banksii (Turner) Decsne, Ulva lactuca L., Pterocladia pinnata (Huds.) Papenfuss, Scytothamnus australis (J.Ag.) Hook.f.\& Harv., Splachnidium rugosum (L.) Grev., Chondria macrocarpa Hook.f. \& Harv. and Colpomenia sinuosa (Roth) Derb. \& Solier, the latter two of which are commonly epiphytic on Corallina. Often occurring in deep midittoral pools and frequently extending into the sublittoral fringe is Cystophora scalaris J.Ag. 
The coralline alga community continues into the sublittoral to a depth of $6-7 \mathrm{~m}$ where the common species are Corallina cuvieri Lamouroux and (Cheilosporum) Arthrocardia corymbosa (Lamk.) Dcn., together with rich covers of Lithothamnium and Lithophyllum.

3. Upper Sublittoral Zone (Infralittoral Fringe) $(0-\mathrm{Im}$ )

The first fringe weed encountered is a narrow ( $>50 \mathrm{~cm}$ wide) carpet of Champia novaezelandiae (Hook.f.\& Harv.) J.Ag. which characterises the upper reaches of the sublittoral on the exposed shores of Cook strait (Adams 1972). This is sometimes interspersed with the dense Lophurella caespitosa (Hook.f.\& Harv.) Falk. Immediately below this and often overlying it is a pronounced band of Zonaria turneriana J.Ag. which is the dominant alga at depths down to lm. Between the holdfasts spread occasional mats of Caulerpa sedoides (R.Br.) C.Ag. The Zonaria band is between $60-80 \mathrm{~cm}$ in vertical extent and is normally interspersed with clumps of Xiphophora chondrophylla (R.Br.) Harv. var. maxima (J.Ag.) Heine, and to a lesser extent Glossophora kunthii (C.Ag.) J.Ag. which is more frequent during the winter. Skirts of xiphophora dominate in areas of vigorous surge e.g. shallow horizontal benches. Patches of these latter weeds extend to $2-3 \mathrm{~m}$ depth.

\section{Sublittoral Zone}

Three horizontal belts, two of which are dominated by brown algae are conspicuous between 1 - 10m depth, although their boundaries are often indistinct. 
(a) At Im depth (i.e. immediately above the lower level of Zonaria) the beginnings of the prominent Carpophyllum maschalocarpum (Turn.) Grev. belt, which is 1 - $3 \mathrm{~m}$ in width depending on the exposure, is encountered. Abruptly beneath this is the 'oakweed' Landsburgia quercifolia (Hook.f.\& Harv.) Harv. and it is at this depth $(2-3 \mathrm{~m})$ that the first crowns of the dominant deeper water laminarian Lessonia variegata J.Ag. appear. Interspersed with this broad band of Carpophyllum is the occasional stand of Marginariella boryana (A. Rich.) Tandy. Between 4 - 5m, isolated stands of Ecklonia radiata (C.Ag.) J.Ag. occur, as do further plants of Landsburgia.

(b) At 5 - $6 \mathrm{~m}$ a very dense belt of the green 'sea-rimu' Caulerpa brownii Endl. var. selaginoides J.Ag. is the dominant vegetation which is interspersed with C. sedoides. The appearance of rhodophytes in the form of Pterocladia lucida (Turn.) J.Ag. and Melanthalia abscissa (Turn.) Hook.f.\& Harv. takes place at this level and $\underline{P}$. pinnata extends to this level from the midlittoral. Subtidal corallines still persist on rock areas uncovered by other macrophytes.

(c) At 8 - $10 \mathrm{~m}$ the vegetation is dominated by Lessonia variegata which forms large crowns, beneath the canopy of which isolated patches of Caulerpa brownii

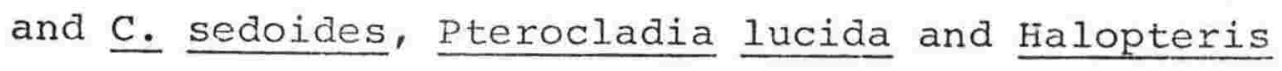


spicigera (Aresch.) Moore occur. At 10m where the cover of Lessonia and Ecklonia is broken, the long tresses of Cystophora retroflexa (Labill.) J.Ag. and Sargassum sinclairii Hook.f.\& Harv. are frequently observed. Also at $8-10 \mathrm{~m}$ are a sparsely scattered number of gigartinaceans, particularly Gigartina atropurpurea J.Ag. and clumps of the less exposed, deeper water form of Zonaria turneriana (see Dahl, 1969, for discussion on variation in growth form in Zonaria).

Below 10m at the study area the bottom grades into a gently sloping substrate composed chiefly of highly mobile, rounded pebbles. These serve as attachment for rapidly growing Ulva lactuca during periods of prolonged calm weather, particularly in summer. A large number of rocky outcrops occur at this depth which invariably are covered by Lessonia, Ecklonia, Cystophora retroflexa with understory mats of Caulerpa brownii, Halopteris and a few small pterocladia lucida.

SEASONAL CHANGES IN ALGAL GROWTH CHARACTERISTICS

The effect on faunal population fluctuations of seasonal growth and decay of the algal substrate has been emphasised previously (Mukai 1971, Norton 1971). No published data are available on seasonal variability in growth form of the algae selected for this study within New Zealand waters. 'Present observations spanning $2 \frac{1}{2}$ years suggests that little, if any, noticeable perennality occurs in the algae utilised here. 
Enteromorpha desiccates in summer but in those supralittoral pools studied the species never completely disappears. New growth takes place in early autumn. Winter erosion of frond margins can be observed in sublittoral Ecklonia and is probably related to increased turbulence at this time. However large scale changes in growth form were not evident.

\section{SAMPLING}

Preliminary investigations at Island Bay from December 1972 to March 1973 into the harpacticoid faunas of all macrophytic algae were made along a transect of increasing depth to $10 \mathrm{~m}$. This was done to determine the most profitable algal species for continuous seasonal sampling and those representing different structural types and depth zones.

Those subsequently selected fell into four physiognomic types following the classification of Dahl (1948:40).

1. Supralittoral pools

(a) fine tube-like algae - Enteromorpha intestinalis (L.) Greville

2. Midlittoral pools

(a) calcareous shrub-like algae - Corallina officinalis L. 3. Sublittoral zone

(a) 'band and thong' algae - Zonaria turneriana J.Ag.

- Xiphophora chondrophylla (R.Br.) Harv.

(b) coarser shrub-like algae - Pterocladia lucida (Turn.) J.Ag.

(c) broad leathery algae - Ecklonia radiata (C.Ag.) J.Ag. 
16 .

Quantitative sampling was conducted at monthly intervals from April 1973 - March 1974. Collections were made at high water during the last week of each month. All sublittoral samples were collected using SCUBA, with duplicate and in some cases triplicate samples taken of each seaweed, resulting in a total of 154 samples collected over the period. Due to the excessive time required for hand sorting of fauna, sampling was conducted for only one full year.

Kajak (1971) has reviewed the various apparatus for sampling aquatic macrophytes. However, none of the methods quoted had the combined advantages of small size, portability and efficiency when used with SCUBA. A modified Larkum (Larkum et al. 1967) seaweed sample cutter was thus constructed and consisted of a wooden frame with dimensions of $10 \mathrm{~cm} \times 10 \mathrm{~cm}$. A plankton mesh bag $(0.1 \mathrm{~mm}$ mesh diam.) was attached posterior to a sliding door with a sharpened falling edge which acted as a blade. The frame was placed firmly against the sublittoral rock surface and by slicing off the algae at the holdfast/rock interface the entire weed sample was isolated. The algal sample was carried into the plankton bag by rapidly drawing the bag through the water, tied, then detached and another sample bag fastened. A number of samples could be collected on a single dive since the sample bags were readily interchangeable underwater. For use in supralittoral and midlittoral samples, deep pools with abundant algal coverage were selected which facilitated easier handing of the sampler on sloping and vertical surfaces. 
To determine the variability of the sampling method, 5 replicate samples were collected from each of Zonaria and Pterocladia, analysed, and the mean, variance and standard deviation calculated. The data were consistent with the expectation that the variance is proportional to the mean with a Poisson type model. Thus Zonaria $V=0.93 \%$ of $\bar{x}$; Pterocladia $V=0.50 \%$ of $\bar{x}$. Previous authors (e.g. McIntyre \& Murison 1973) indicate that the standard deviations of respective samples were proportional to the mean, which is again acceptable from the above data since zonaria S.D. $=5.2 \%$ of $\bar{x} ;$ Pterocladia S.D. $=5.0 \%$ of $\bar{x}$.

These would suggest that a count such as $86.10 \mathrm{~cm}^{-2}$ for the summer population peak on Zonaria is within an accuracy range of \pm 9 individuals. These results, of course, correspond to approximate 95\% confidence intervals. Numerical differences of this order were considered acceptable for detecting month to month changes in population density of copepods.

\section{SORTING}

Sample bags were returned to the laboratory and placed in a large tray containing a solution of magnesium chloride isotonic to seawater of $35 \%$. $\mathrm{MgCl}$ is well known as a narcotizing agent (Hulings \& Gray 1971:27) and was used to overcome the initial 'clinging reaction' which characterizes much of the phytal fauna on direct application of preservative. Algal samples were then shaken vigorously in $10 \%$ formalin to remove any clinging specimens. Examination under a binocular microscope indicated that this method was successful and an estimate of over $90 \%$ efficiency was calculated. 
Samples at this point contained large quantities of seaweed fragments and mucilaginous residue plus members of many other meiofaunal and macrofaunal groups. It was thus necessary to separate the meiofauna from the residues and larger organisms. Various flotation techniques were investigated including 1,2 - Dibromoethane (Mol. Wgt. 187.87 Wgt. $/ \mathrm{ml}=$ between 2.17 and $2.18 \mathrm{~g} / 20^{\circ} \mathrm{C}$ ). Theoretically animals should float at the seawater reagent interface but in practice many animals become trapped in the water adhering to large plant particles. Also the fact that toxic vapour is given off during the flotation procedure caused this method to be discarded.

Sugar solutions have been used by a number of workers (e.g. Fast 1970, Lackey \& May 1971) and centrifugation of sucrose solution has been effectively applied to the meiobenthos of mud and detritus by Heip et al. (1974). These methods invariably suffered from adherence of organisms to detritus and made all instruments unpleasantly sticky. The elutriation technique described by Boisseau (1957) and used extensively by meiobenthic ecologists was attempted, but again it was not possible to separate plant residues and some of the larger crustacean fauna. It was eventually decided to hand sort the samples in seawater after removing larger material on a $2 \mathrm{~mm}$ sieve. Hulings \& Gray (1971) recommend sieving and hand sorting samples which contain large fractions of organic detritus, although this is known to be tedious and time consuming. 


\section{9.}

A shallow graduated petri dish ( $9 \mathrm{~cm}$ diam.) was used for sorting and the harpacticoids and their copepodite stages were individually picked out with a Pasteur capillary pipette. The specimens were then identified, separated and transferred to corked vials containing a $2: 1$ mixture of $5 \%$ formalin in seawater and $50 \%$ monoethylene glycol. The number of each species was recorded. Counting efficiency was estimated at almost $100 \%$.

For the midlittoral pool samples of Corallina officinalis which contained a high silt fraction, a 'swirling-decantation' method was used. This has been ranked as the most effective quantitative method of separation of both hard and soft bodied meiofauna (Uhlig et al. 1973). The formalin-fixed sample was placed in a beaker of sea water and stirred vigorously. While the heavier particles sank the water was decanted off through a sieve of $0.1 \mathrm{~mm}$ plankton gauze. The netting was then inverted and the organisms washed into a petri dish to be examined under a low power stereomicroscope. Each sample received three such decantations. Inevitably a few animals were lost in this process, but by comparison with some small samples in which the total population was counted by careful sorting of the sediment under low magnification, the total recovery was tested and estimated to be better than $95 \%$.

\section{ENVIRONMENTAL VARIABLES AT THE STUDY SITE}

\section{TIDAL RANGE \& WATER MOVEMENTS}

Strong irregular tidal streams arise as a result of the difference in tidal height from the western to the eastern end of Cook Strait (Heath 1973). Tides are semi-diurnal and tidal 
range is between $1.40 \mathrm{~m}$ at mean high water springs and $0.40 \mathrm{~m}$ at mean low water springs. Mean sea level is $0.88 \mathrm{~m}$ (N.Z. Nautical Almanac and Tide Tables 1975).

In this exposed area subtidal water movement is vigorous and during the frequent storms inundation of many of the higher supralittoral rock pools takes place.

\section{TEMPERATURE}

Seawater temperatures were measured with a mercury thermometer read to $0.1^{\circ} \mathrm{C}$ between 0900 and $0930 \mathrm{hrs}$ every other day from April 1973 to March 1974. The three zonal levels were monitored by placing a thermometer into a bucket of freshly collected seawater.

The annual cycle of seawater temperature at Island Bay is shown in Fig. 2. Mean annual seawater temperature was $14.3^{\circ} \mathrm{C}$ for the supralittoral pool environment, $13.7^{\circ} \mathrm{C}$ for the midittoral and $13.6^{\circ} \mathrm{C}$ for the sublittoral. Maximum monthly temperatures were $19.7^{\circ} \mathrm{C}, 16.7^{\circ} \mathrm{C}, 16.2^{\circ} \mathrm{C}$ in the supralittoral, midlittoral and sublittoral respectively. February was the warmest month at all levels. Minimum temperatures of $8.3^{\circ} \mathrm{C}$ in the supralittoral, $10.1^{\circ} \mathrm{C}$ in the midlittoral and $10.9^{\circ} \mathrm{C}$ in the sublittoral were recorded.

The coolest month for the supralittoral and midlittoral was July while sublittoral temperatures were coldest in August.

Summer temperature depressions noted at the same site by Ritchie (1970) in February were evident two months earlier in 1.973. These apparently result from cold water pulses into the Cook Strait area (Garner 1961). Sharp temperature depressions as a result of increased onshore transport of cool 
FIG. 2 - Seasonal variation in a: air and b: seawater temperature during the study period. Air temperature data obtained from N.Z. Meteorological Service. Triangles indicate supralittoral pool, open circles indicate midlittoral pool and closed circles indicate sublittoral temperatures. 


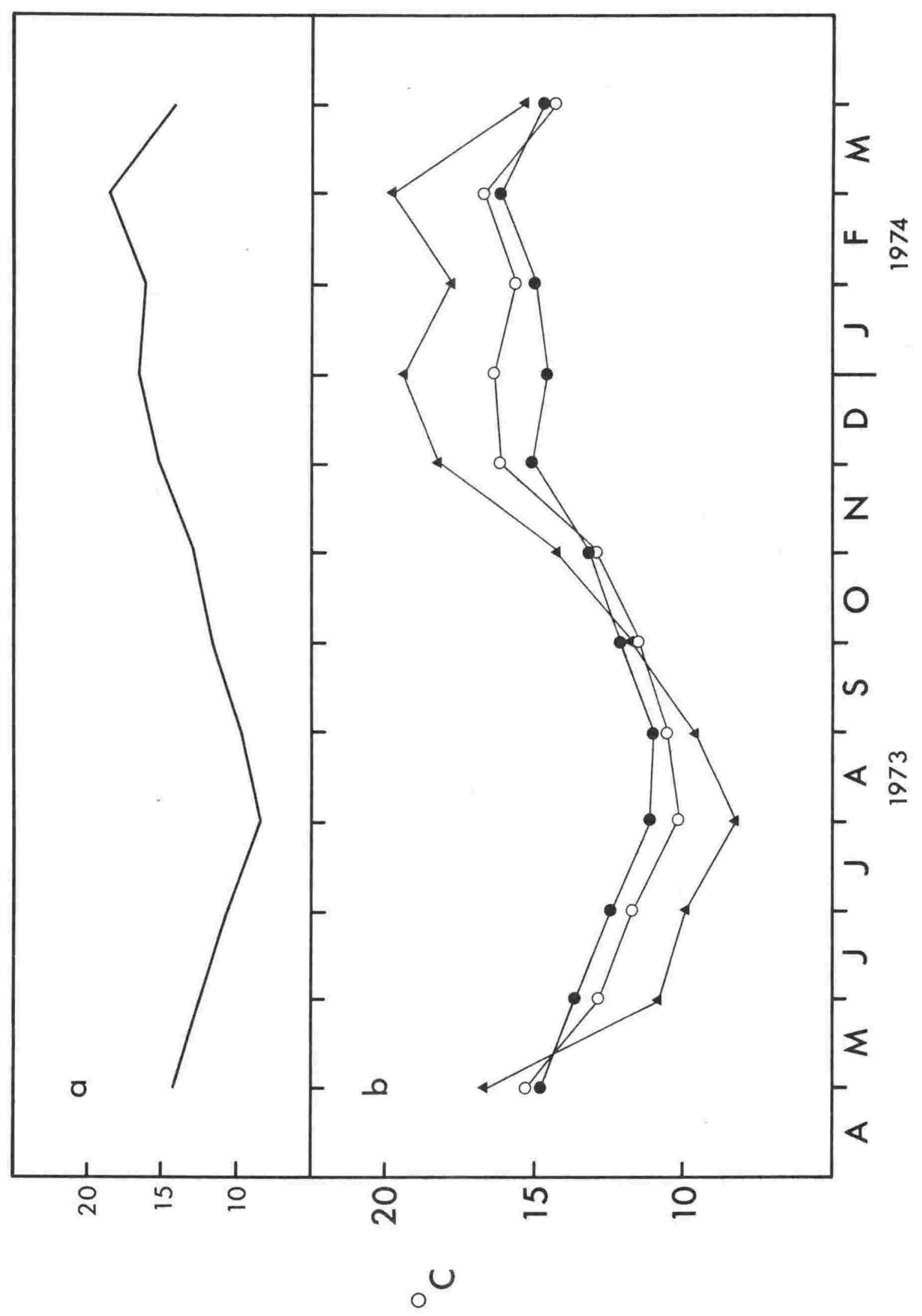


subantarctic surface water may also occur during periods of strong southerly wind (Heath 1970) and temporarily affect the local thermal characteristics. The months July, August and December 1973 and March 1974 were noted for their high frequency of southerlies. (N.Z. Meteorological office Records). Minimum temperatures and temperature depressions in the sublittoral correlate with these months (Fig. 2). Temperature depressions in January 1974 in the supralittoral and midlittoral pools are expressions of the air temperature (Fig. 2). Positive and negative anomalies of supralittoral and midtidal temperatures in summer and winter reflect the more rapid heating and cooling of the surrounding rock platform.

\section{SALINITY}

Surface salinity measurements were taken concurrently with temperatures. Field measurements were made with a hydrometer and determined to the nearest $0.5 \%$ from Knudsen Tables. Further samples were returned in glass stoppered bottles to the laboratory for determination on an inductively coupled salinometer.

There was no freshwater influence on the sublittoral zone and little intertidally (Fig. 3). Mean annual salinity for both zones lies within the 34.5 - 35.0\% range observed for more offshore waters (Gilmour 1960, Heath 1971). Supralittoral salinities were extremely variable. Mean annual salinity was $31.3 \%$ while the lowest single recording was $6.6^{\circ} / 00$ on 7 November 1973 following heavy rain. The single highest salinity recorded was $53.8 \%$ on 31 January 1974 . High mean salinities during the summer result from the increased rate of evaporation. 
23.

FIG. 3 - Seasonal variation in a: rainfall and b: seawater salinity during the study period. Rainfall data obtained from N.Z. Meteorological Service. Triangles indicate supralittoral pool, open circles indicate midittoral pool and closed circles indicate sublittoral salinities. 


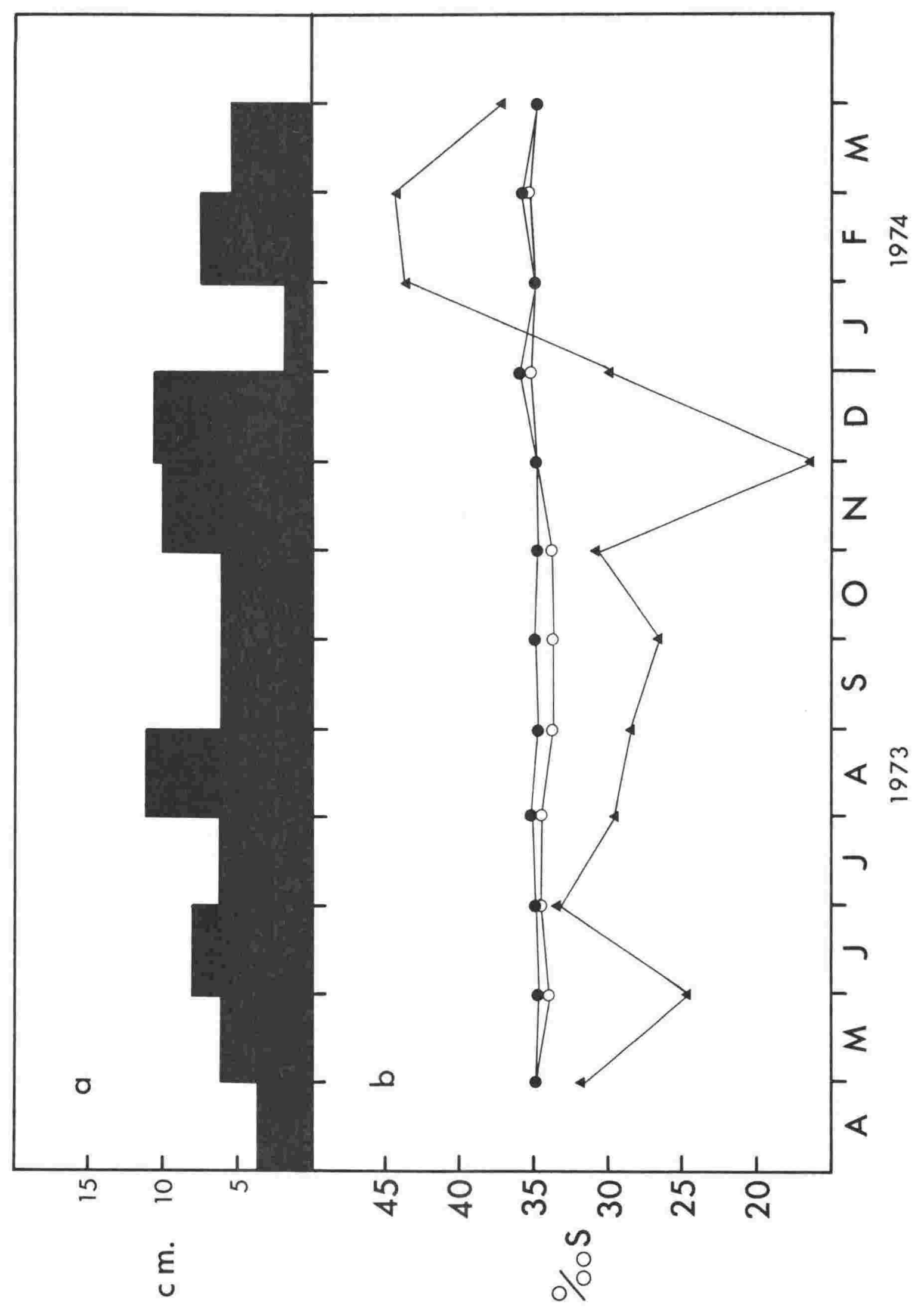


WIND \& STATE OF SEA

Observations on wind and state of sea were made simultaneously with temperature and salinity determinations. Wind characteristics were ranked using the Mariners Beaufort Scale and in Fig. 4 represent total wind activity based on the monthly mean wind strengths. State of the sea was based on an arbitrary 1 - 10 scale and is summarized accordingly in Fig. 4. Both parameters show maximal activity around mid-late autumn and spring.

From Fig. 4 it is evident that the state of the sea does not always reflect the influence of local wind patterns. This suggests that the prevailing sea conditions are initiated and influenced by climatic disturbances distant from the immediate cook strait area. In this case low pressure centres moving over the south of the South Island from the west give rise to heavy ground swells which enter eastern Cook strait from their point of generation to the south.

\section{PARTICLE SIZE}

The compact, bushy growth form of Corallina officinalis serves as an effective trap for suspended sediments and detritus in the sheltered midlittoral pools. Within the region of the holdfast a thick compact sediment develops providing a suitable habitat for a large number of harpacticoid species.

A cumulative curve was constructed from an analysis of these sediments (Fig. 5), utilizing the method described by Morgans (1956). Median diameter expressed in Phi ( $\phi$ ) units, $\varnothing$ quartile deviation and $\varnothing$ quartile skewness were calculated. A Phi scale utilizes logarithmic values for particle diameter and so transforms the arithmetically inequal class intervals 
25.

FIG. 4 - Seasonal variation in a: wind strength and $\mathrm{b}$ : state of the sea during the study period. 


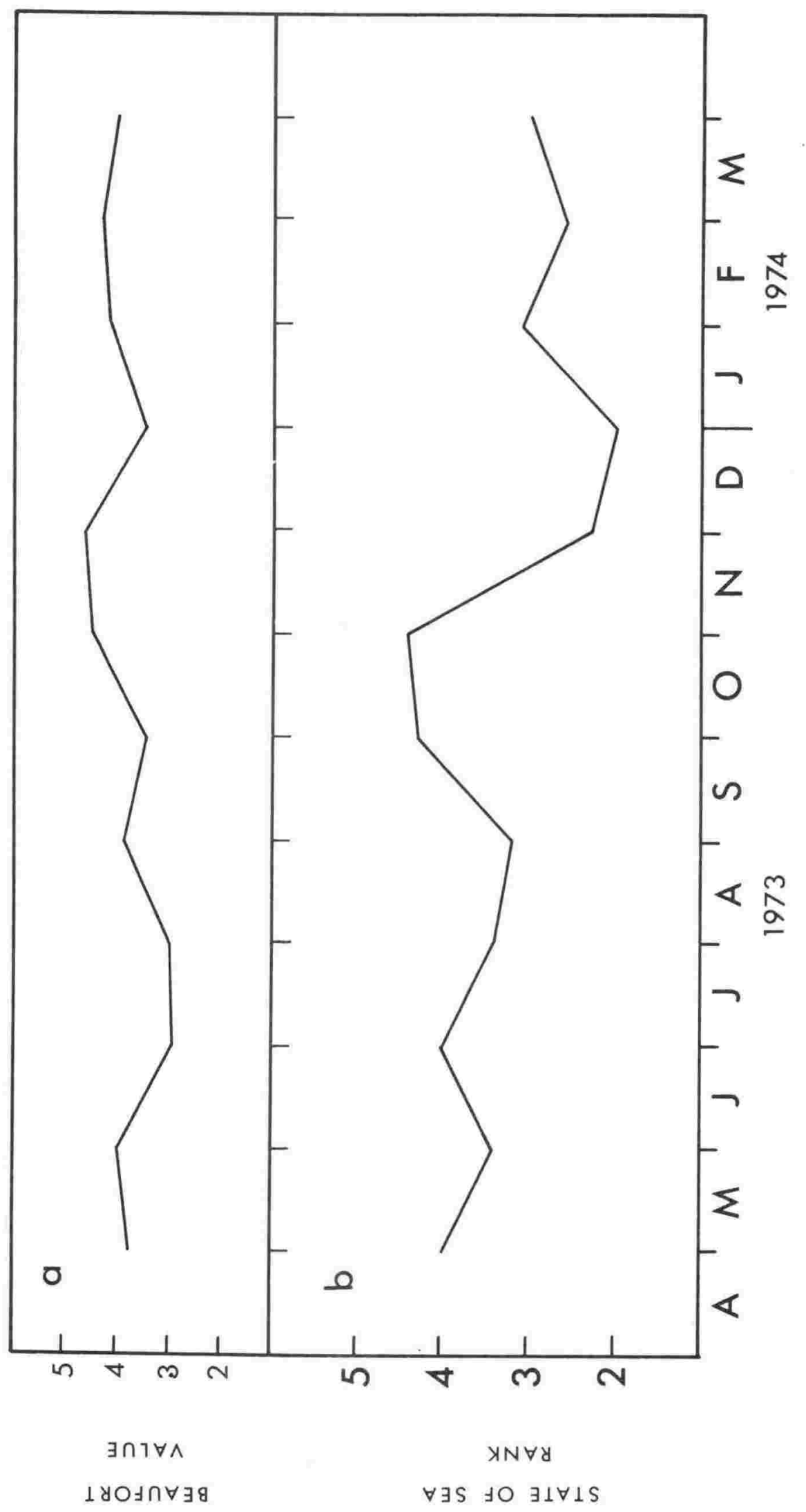


26.

FIG. 5 - Cumulative curve constructed from sand particle analysis of midlittoral

Corallina sediments. 


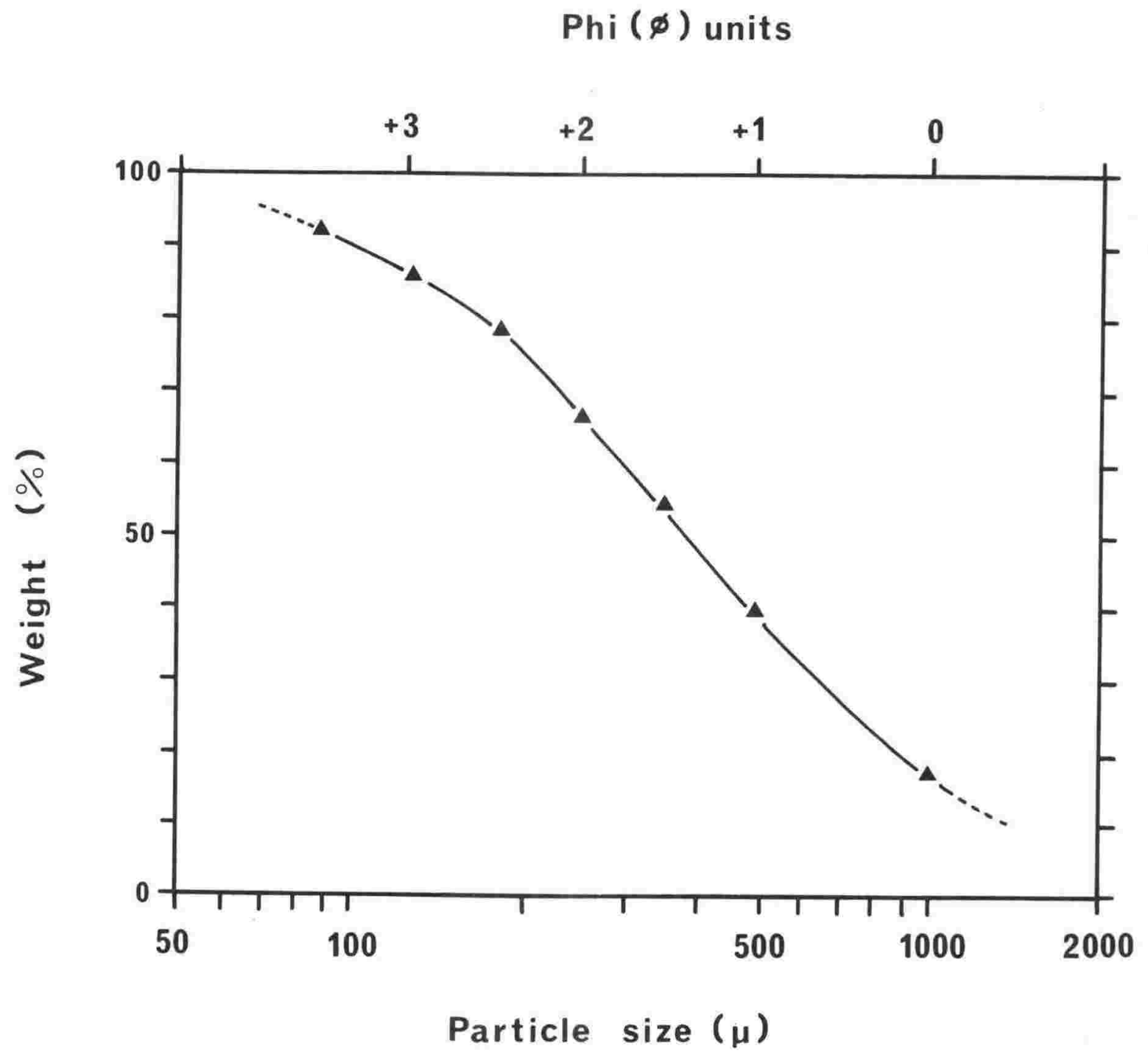


of the Wentworth scale into equal intervals.

The sediment has a median diameter of $1.41 \varnothing$ (medium sand on the Wentworth grade scale), but has a high level of fine material indicated by the slope of the curve. It is a poorly sorted sediment with a Phi quartile deviation (QD $\varnothing$ ) of 1.00, and the Phi quartile skewness (SKQ $\phi$ ) is low $(-0.09 \phi)$ suggesting that the larger particles are less well sorted than the smaller ones. Once the sediment becomes lodged between the fronds of the seaweed, it is probably not then worked on by the sea to cause attrition of the particles. This accounts for poor sorting of these sediments.

Calcium carbonate analysis (acid dissolution technique) revealed a low percentage composition in the sediments (12.5\%). The relative quantity of accumulated sediments was assessed from all algae as grams dry weight per $10 \mathrm{~cm} \times 10 \mathrm{~cm}$ algal sample (Table 1 ).

\section{ALGAL SURFACE-AREA DETERMINATION}

The sampling method allows for expression of the number of individuals $10 \mathrm{~cm}^{-2}$ of algal covered rock surface and is an expression consistent with level-bottom meiofaunal studies. Many workers in the past have related the numerical abundance of algal faunas to weight of the algal sample. This procedure ignored the difference in weight proportional to sample size of such 'heavier' algae as corallines or laminarians as opposed to lighter filamentous species, and also the available surface areas of finely branched versus flat thalloid forms. Anyquantitative comparisons of faunas between seaweed species must acknowledge that the surface area of such algae is highly variable and differences in the 
copepod species composition and density are likely to be similarly affected. Although algae were collected with a $100 \mathrm{~cm}^{2}$ sampler and copepod densities were expressed as No. $10 \mathrm{~cm}^{-2}$ of rock face, the actual habitable surface within $100 \mathrm{~cm}^{2}$ is dependent upon the species of algae and its relative surface area.

Westlake (1971) has reviewed the methods whereby a meaningful index to the surface area of macrophytes can be obtained. An improved modification of Wieser's (1951) 'Adsorption Koeffizient' has been devised by Harrod \& Hall (1962) and is utilized here.

To standardize the measuring procedures, sheet polythene was cut into sections of known surface area and weighed on a Mettler P1200 balance. After weighing each section was immersed in a solution of commercial detergent which by reducing surface tension produced a thin film over the entire surface. This is then re-weighed and the difference recorded. Up to five replicate measurements were made for each section. The procedure was repeated for polythene sections of differing surface areas.

The method is based on the assumption that the increase in weight due to the addition of detergentfilm, is directly proportional to the surface area of the structure. There is thus a significant linear relationship ( $r=0.99, \mathrm{P}>0.005)$ between the computed surface area with that of the surface film (Fig. 6).

Calculations of surface area of algae are obtained by repeating the above procedures. A sample of alga of known weight (Igm) was externally dried with acetone, immersed in the detergent solution and reweighed. The surface area of 
the sample was then read from the calibration curve (Fig. 6). Surface area of the total $10 \mathrm{~cm} \times 10 \mathrm{~cm}$ sample is calculated as the product of the weight of the sample and the surface area of lgm of algae.

Results are presented in Table 1, and it is evident that surface area is clearly unrelated to weight of algae. For example the heaviest algae sampled (Xiphophora, Ecklonia) exhibit the lowest available surface areas for faunal utilization. The large discrepancy observed between the estimated surface areas of Enteromorpha with that by direct measurement (using standard mathematical techniques, i.e. area of cylinder etc.) is explained by the morphology of the plant. Enteromorpha is an open-ended tubular algae, so when immersed in detergent a covering of both inner and outer surfaces occurred, effectively doubling an increase in weight. Halving the figures provides a more appropriate result which is close to the figures obtained by direct measurement (see Table 1).

Enteromorpha and Corallina have the highest surface area available within a sample. This accords with the copepod population density figures from each of these algae, which support higher maximum densities than the remaining four species. Lower available surface area in the sublittoral seaweeds results in reduced sublittoral population densities (Hicks in press a). 


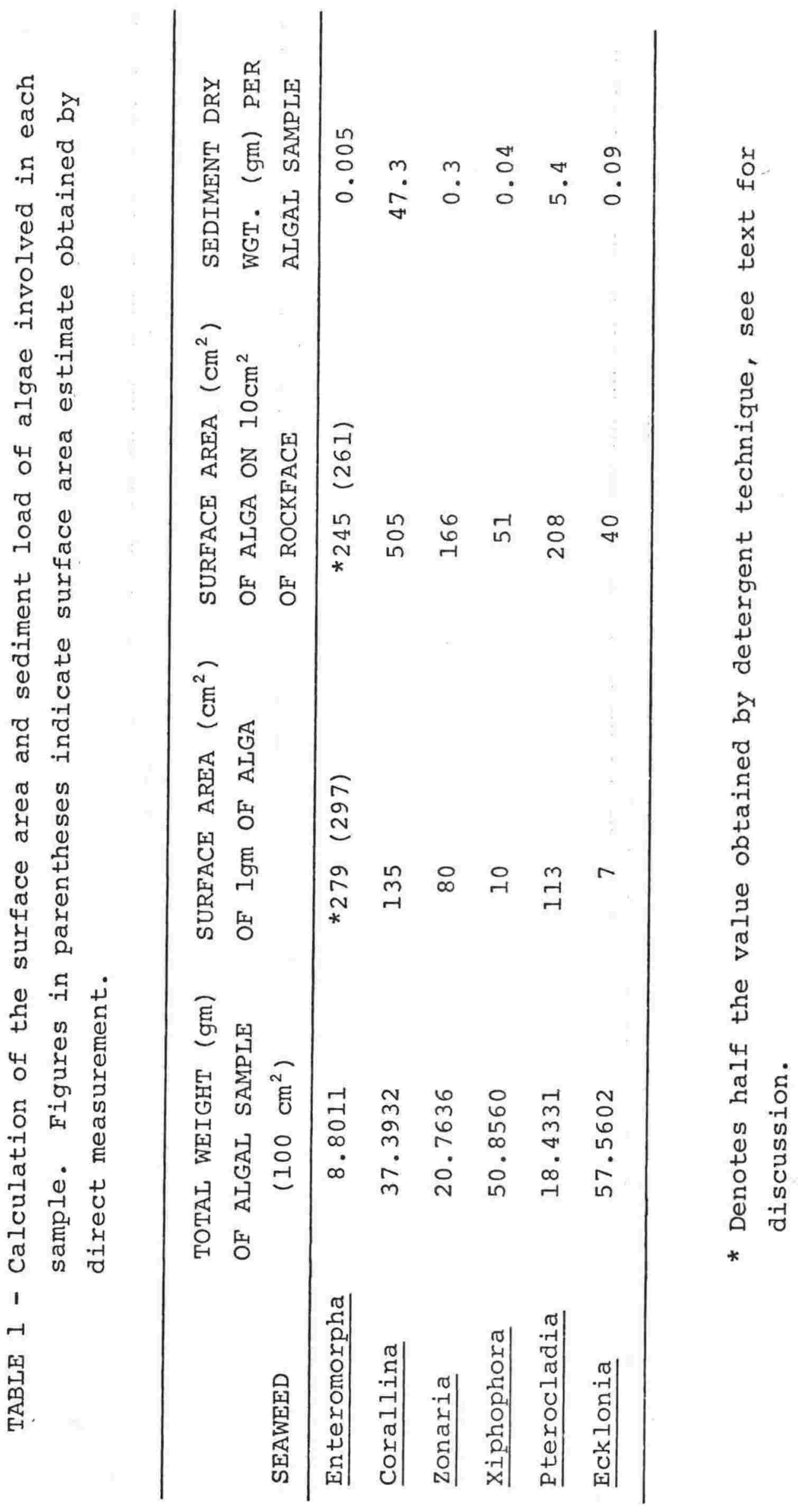


31.

FIG. 6 - Weight of surface film (gm) plotted against surface area (sq. $\mathrm{cm}$ ) of polythene standard, with fitted regression line. 


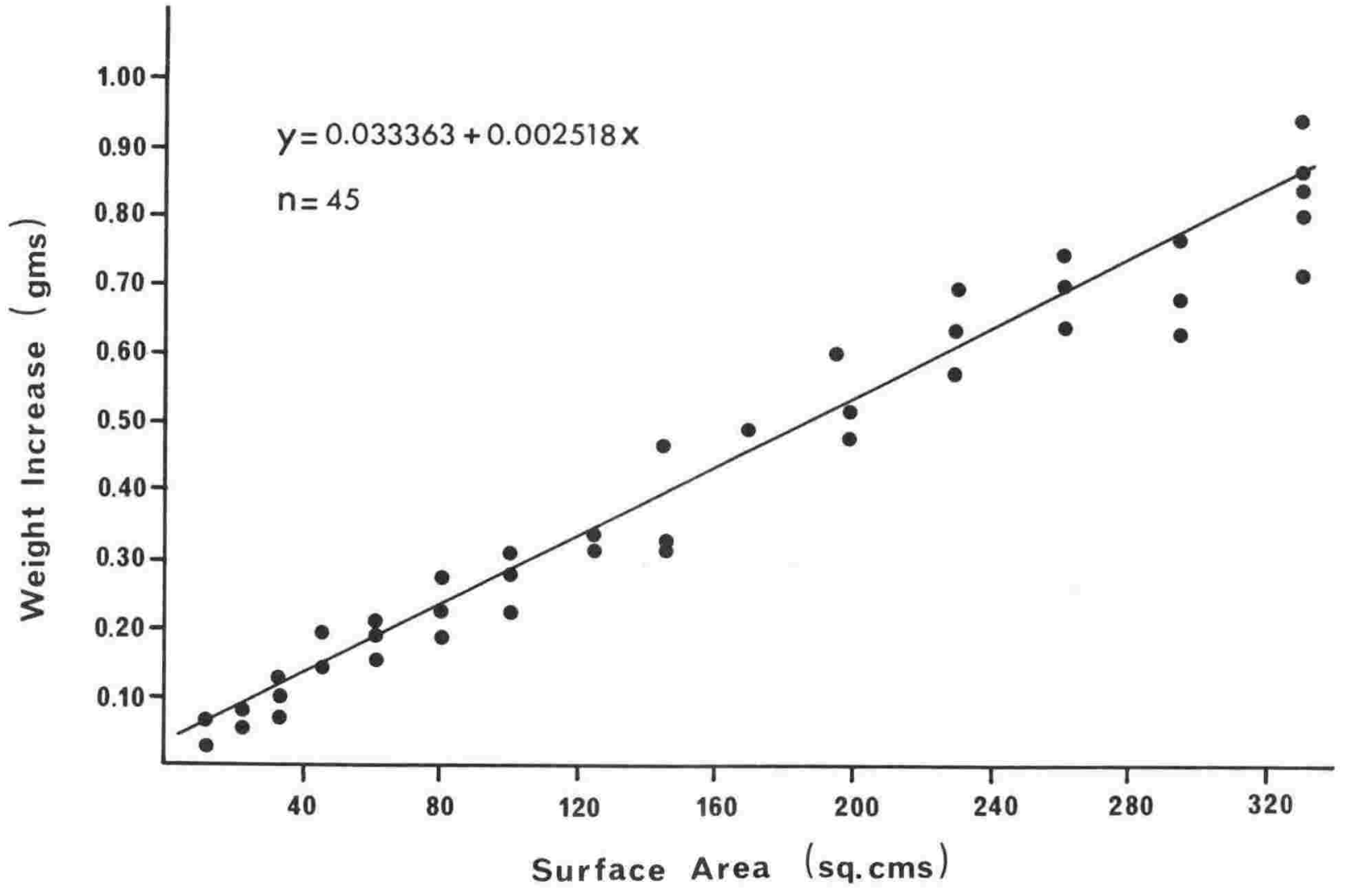




\section{SPECIES COMPOSITION}

Over 59000 individual harpacticoids have been collected from all algae during this study. A total of 66 species and 1 variety are recognized and fall into 39 genera and 16 families (Table 3). Numerically the most important family is the Diosaccidae, the species of which contribute $18.8 \%$ of the total fauna (Table 2). This is also the most diverse family, with 12 species. Subdominance is shared between the Laophontidae (17.4\%), Tisbidae (17.1\%) and the Porcellidiidae (13.0\%). These four families together constitute two-thirds of the total fauna represented. Only six families have an average dominance less than $1 \%$ (Table 2).

SYSTEMATIC AND ZOOGEOGRAPHIC NOTES ON SELECTED SPECIES

Many of the species recorded are, or may be, new to science. Definitive descriptions are being prepared and will appear as part of a major revision of the Australasian Harpacticoida which is being undertaken in collaboration with Dr Richard Hamond of Melbourne University. However in order to facilitate accurate sorting for the collection of raw ecological data, it was necessary to elucidate and clarify the taxonomic position of a number of the species discussed below. The taxonomy follows Lang (1948, 1965) and Bodin (1967, 1971). 
TABLE 2 - Taxonomic composition of the algal-dwelling Copepoda (Harpacticoida) at Island Bay, 1973-74

\begin{tabular}{|c|c|c|c|}
\hline $\begin{array}{l}\text { Family } \\
\text { (Taxonomic order } \\
\text { follows Lang 1948) }\end{array}$ & $\begin{array}{l}\text { Number of } \\
\text { Species and } \\
\text { Variety }\end{array}$ & $\begin{array}{l}\text { Total Number } \\
\text { of Individuals } \\
\text { of All Species }\end{array}$ & $\begin{array}{l}\text { Percentage } \\
\text { No. of } \\
\text { Individuals }\end{array}$ \\
\hline Ectinosomidae & 2 & 2101 & 3.55 \\
\hline Harpacticidae & 7 & 2328 & 3.94 \\
\hline Tisbidae & 5 & 10117 & 17.12 \\
\hline Porcellidiidae & 6 & 7674 & 12.99 \\
\hline Peltidiidae & 4 & 4406 & 7.46 \\
\hline Tegastidae & 2 & 51 & 0.09 \\
\hline Thalestridae & 7 & 3409 & 5.77 \\
\hline Diosaccidae & 12 & 11089 & 18.76 \\
\hline Metidae & 1 & 14 & 0.02 \\
\hline Ameiridae & 3 & 1071 & 1.81 \\
\hline Tetragonicipitidae & 1 & 264 & 0.45 \\
\hline Canthocamptidae & 2 & 5861 & 9.92 \\
\hline Cletodidae & 2 & 48 & 0.08 \\
\hline Laophontidae & 10 & 10263 & 17.37 \\
\hline Ancorabolidae & 2 & 25 & 0.04 \\
\hline Louriniidae & 1 & 372 & 0.63 \\
\hline Total & 67 & 59093 & 100.00 \\
\hline
\end{tabular}


TABLE 3 - Species list and records of the Copepoda Harpacticoida collected from Island Bay algae, 1973-74. Note: species occurring within the "New Species" column are to be included in later taxonomic work in preparation; species marked "cf." indicates those which resemble others closely related to them - their identity must remain uncertain until larger numbers of specimens can be examined or type material studied; otherwise the remaining species conform to previously published descriptions.

Species

$\begin{array}{ccl}\text { New Record New } & \begin{array}{l}\text { Pecord } \\ \text { for }\end{array} & \text { New } \\ \text { Southern New Zealand } & \\ \text { Hemisphere } & & \end{array}$

\section{ECTINOSOMIDAE \\ Ectinosoma melaniceps Boeck \\ $\underline{\text { Ectinosoma australe }}$ Brady}

$+$

HARPACTICIDAE

Harpacticus pulvinatus Brady

Harpacticus furcatus Lang

Tigriopus angulatus

Lang (Thomson)

Zausopsis mirabilis Lang

Harpacticus sp. G

Harpacticus sp. L.

TISBIDAE

Tisbe holothuriae Humes

Scutellidium plumosum Brady

Scutellidium armatum (Wiborg)

Scutellidium spinatum Hicks

Scutellidium macrosetum Branch

PORCELLIDIIDAE

Porcellidium dilatatum Hicks

Porcellidium erythrum Hicks 
Porcellidium sp. A

35.

Porcellidium sp. B

Porcellidium sp. C

porcellidium sp. D

PELTIDIIDAE

Alteutha littoralis

Pallares

Alteutha sp.

Eupelte regalis Hicks

Neopeltopsis pectinipes Hicks

TEGASTIDAE

Tegastes sp. A

Tegastes sp. B

THALESTRIDAE

Parathalestris sp.

Diarthrodes cf. imbricatus (Brady)

Dactylopodia tisboides

(claus)

Dactylopodia cf. frigida (T. Scott)

Paramenophia sp.

Paradactylopodia brevicornis (Claus)

Idomene novae-zealandiae (Thomson)

DIOSACCIDAE

Robertsonia propinqua

(T. Scott)

Amphiascus hirtus

Gurney

Amphiascus lobatus

Hicks

Amphiascopsis cinctus (Claus)

Amphiascopsis southgeorgiensis (Lang)

Amonardia perturbata

Lang

Bulbamphiascus imus (Brady)

Bulbamphiascus sp.

Typhlamphiascus unisetosus Lang

Amphiascoides nichollsi Lang

Amphiascoides sp.

Paramphiascella sp. 
AMEIRIDAE

36 .

Amejra minuta Boeck

Ameira parvula (Claus)

Psyllocamptus sp.

TETRAGONICIPITIDAE

Phyllopodopsyllus cf.

minor (Thompson \& A. Scott)

?

CANTHOCAMPTIDAE

Mesochra flava Lang

Orthopsylius cf. Iinearis

$+$ (Claus)

CLETODIDAE

Stylicletodes longicaudatus (Brady \& Robertson)

Enhydrosomella sp.

\section{LAOPHONTIDAE}

Laophonte cornuta

Philippi ('normal' form)

Laophonte cornuta Philippi var. nigrocincta Nicholls

Laophonte cf. inornata A. Scott

Laophonte cf. sima Gurney

Heterolaophonte cf. longifurcata lang

Heterolaophonte sp.

Paralaophonte meinerti (Brady)

Paralaophonte sp.

Coullia sp. A

Coullia sp. B

$\begin{array}{ll}+ & + \\ ? & ? \\ ? & ? \\ ? & ?\end{array}$

ANCORABOLIDAE

Laophontodes hamatus

(Thomson)

Laophontodes sp.

?

?

?

LOURINI IDAE

Lourinia armata (Claus) 
Fam. Ectinosomidae

Ectinosoma melaniceps Boeck; E. australe Brady

E. australe Brady, originally described from otago Harbour was considered by Lang (1948) to be synonymous with E. melaniceps Boeck. Apart from being slightly smaller, E. australe consistently possesses a reddish-black band around the genital double segment (see also Pallares 1970) which is lacking in E. melaniceps. E. melaniceps has a black prosome and the rest of the body is pale. Since both forms occur in my samplesand appear distinct, and as colour pattern is a distinguishing feature in this genus (see Lang 1965, p.18), I favour the reinstatement of $\underline{E}$ australe as a valid species.

E. melaniceps is cosmopolitan in distribution, with New Zealand records in Sars (1905 - Chatham Islands) and Lang (1934) from both Campbell and stewart Islands.

The species occupies a wide range of biotopes, from the deep sea $(350-400 \mathrm{~m})$ to the psammic and phytal (Lang 1948, Wells 1970). Revision of this genus including analysis of the constancy of colour patterns within each population is required.

Fam. Tisbidae

Tisbe holothuriae Humes

Dr B. Volkmann (Instituto di Biologia del Mare, Venice) has identified my specimens as $T$. holothuriae which she now considers cosmopolitan, since her collections have shown it to occur also in U.S.A., Europe and Africa. The first published southern hemisphere record of $\mathrm{T}$. holothuriae is by Kunz \& Kunz (1973) collected from hyperhaline basins of South-West Africa. 
Fam. Peltidiidae

\section{Alteutha littoralis Pallares}

My specimens differ only slightly in the female by the two setae on the internal border of P5 which here are rather shorter and more robust than those figured by Pallares (1968). The baseoendopod has one internal seta and one external. In all other characters my specimens agree well with those presented by Pallares (1968) except for the rather more squared outline of the female P5 exopod.

Fam. Diosaccidae

Robertsonia propinqua (T. Scott)

This species, commonly found in brackish coastal lagoons, tide pools and other shallow marine waters (Lang 1948) has recently been recorded from saline lakes in Australia (Hamond 1973c, d). It had been recorded earlier from the same locality by Bayly \& Williams (1966) and Bayly (1970) as Robertsonia sp. nov. Hamond based his redescription on this material.

My specimens conform more closely to Hamond's redescription than to the original of scott (1893); however the distinct hyaline field on the P5 exopod figured by Hamond (1973d) does not appear to occur in my material.

R. propinqua was first recorded in the southern hemisphere by Pallares (1970) from Argentina. Its former distribution (see Lang 1948; Pallares 1970) together with the more recent records from the Indian Ocean (Wells \& McKenzie 1973) and South west Pacific indicates that $\underline{R}$. propinqua is a circumtropical/cool temperate species. 
Fam. Diosaccidae

Amphiascus hirtus Gurney

This species was first described from the suez Canal zone by Gurney (1927). Lang (1934) records it from Campbell Island which is hitherto the only southern hemisphere record for the species. The Wellington specimens show closer affinities to the Campbell Is. specimens than the Caroline Is. material of . Vervoort (1964). The Wellington and Campbell Is. animals both have the very short outermost seta on the female P5 baseoendopod (see Lang 1948, fig. 264/2a, p.654) which is absent in the Suez specimen. This may have been broken or overlooked in the original or it could genuinely have been absent (Lang. fig. 264/2). The abdominal spinulation of the Wellington specimens also varies somewhat from that of the Ifaluk Atoll material (Vervoort 1964).

Fam. Diosaccidae

Amonardia perturbata Lang

This species has been described by Lang (1965) from Tomales Bay, California but is very similar to $\underline{A}$. tristanense Wiborg described as a new species from Tristan de Cunha (Wiborg 1964). It appears that both descriptions were in press simultaneously and that Lang was ignorant of Wiborg's description. Although Wiborg has precedence, his figures make it difficult to compare accurately his species with the Pacific material. I use Lang's name pending examination of Wiborg's type material. 
My specimens agree almost exactly with Lang's, although the characteristic tenon-like process on the basis of P1 in the male of my specimens is rather larger and 'wart-like'; the exopod of the maxillula has two plumose distal setae (unlike the single seta in the Californian specimens) and small variations occur in the abdominal spinulation of the female.

Fam. Diosaccidae

Bulbamphiascus imus (Brady)

This species is broadly distributed throughout Europe and the Mediterranean (Lang 1948) and Coull \& Herman (1970) consider it cosmopolitan. B. imus has been recorded from the Pacific region by Chappuis (1958 - see Lang 1965 p.6) and the first southern hemisphere record is by Hamond (1973a) from the Yorke Peninsula, Australia.

I have examined specimens from Norfolk, U.K. (R. Hamond collection) which are very similar to my material. The exopod segment 3 of P3, however, has an additional small distally placed seta in my specimens and the two larger normal setae are set rather more closely together. Endopod segment 1 of Pl is slightly shorter than that observed in Norfolk specimens. In the specimens figured by Dinet (1971) the exopod P5 does not have the outer but 2 seta with as bulbous a base as the Island Bay or Norfolk material.

Bulbamphiascus sp. (Table 3) lacks the bulbsetae on P5 and the baseoendopod of P5 has a distinct auricular hyaline zone. 
Fam. Ameiridae

Ameira minuta Boeck

This species is widely distributed throughout the North Atlantic and has been recorded in the Pacific by Vervoort (1964). The present record is the first positive one from the southern hemisphere although Wiborg (1964) is uncertain about the validity of his $A_{-}$minuta from the South Atlantic.

The present material agrees well with that of Sars (1911) and Lang (1948).

Fam. Canthocamptidae

Orthopsyllus linearis (Claus)

I have tentatively identified this species as 0 . Iinearis, although the variability and confusion existing within this 'species group' is as yet unresolved (Wells 1968, Lang 1965, Hamond 1970 etc.). This species has recently been recorded in the southern hemisphere (Pallares 1968) and from the subantarctic (Lang 1934, 1936, Bovée et al. 1973). The identification of this species must remain in question until O. Iinearis topotypic material has been adequately described and the entire genus revised.

Fam. Cletodidae

Stylicletodes longicaudatus (Brady \& Robertson)

Determination of this species is based on a single undissected female which agrees well with Lang's (1965) figures regarding general appearance, structure of A2, P5 and caudal rami. This record of the species in New Zealand must remain tentative until further specimens are collected and examined. 
Fam. Laophontidae

Laophonte cornuta Philippi var. nigrocincta Nicholls

Most New Zealand specimens of Laophonte cornuta appear to belong to the variety nigrocincta first proposed by Nicholls (1944) based on material from the Red sea, in constantly having the three black thoracic segments, but otherwise indistinguishable from 'normal' L. cornuta from Europe (Lang 1948).

Laophonte cornuta is a cosmopolitan species (see Coull \& Herman 1970) and was first recorded from the New zealand region by Brady (1899) (as L. serrata) and by Lang (1934).

Fam. Laophontidae

Paralaophonte meinerti (Brady)

Originally described from Lyttleton Harbour (Brady 1899) and recorded by Lang (1934) at Campbell Island, this species has since been located in the South Atlantic (Pallares 1968; Wiborg 1964) and Dr R. Hamond informs me of its occurrence in the Chatham Islands. The distribution can therefore be considered circumsubantarctic to cool temperate.

P. meinerti appears to have two distinct geographic forms. The southern form (Chatham Is., Campbell Is., Patagonia, Lyttleton on the South Island N.Z. mainland) averages $0.75 \mathrm{~mm}$ in length; while populations of the northern form (Island Bay, Wellington) consist of both this sized form and another which is identical, but only about $2 / 3$ the length of the former. A review of these forms and the closely related $\underline{\mathrm{P}}$. pacifica Lang and $\underline{\mathrm{P} .}$ obscura Vervoort is underway by Dr Hamond. 
ZOOGEOGRAPHY

Compared with the northern hemisphere, the southern hemisphere has received less attention taxonomically, and it is thus difficult to present an accurate assessment of the zoogeography of many of the species involved. However, bearing in mind the tentative nature of such an exercise, there is sufficient present data to divide the fauna into four broad categories (Table 4): (1) cosmopolitan - which are those species previously recorded from quite widely separated world regions, (2) warm temperate and tropical (circumtropical) those species recorded mainly from the mid-latitudes, i.e., Mediterranean, coasts of mid-Atlantic, Pacific and Indian Oceans, (3) antiboreal and antarctic (the term antiboreal of Kunz (1963) is here considered synonymous with southern cool temperate) - species collected from the coasts of cool temperate land masses, e.g. South-west Africa (extending to the cape of Good Hope), southern South America (including the TristanGough Island group), South Australia and Tasmania, central and southern New Zealand; the numerous subantarctic islands of the Pacific, Atlantic and Indian Oceans; the coast of Antarctica. (4) Endemic to New Zealand.

The southern zoogeographic realms may require redefinition with future widespread collecting.

As a result of such collections some species may prove to exhibit more widespread distribution patterns while others may show a quite localised range and therefore a further regional subdivision would become necessary. 
TABLE 4 - Zoogeography of the Island Bay harpacticoid fauna.

1. COSMOPOLITAN SPECIES:

Ectinosoma melaniceps

Dactylopodia tisboides

Paradactylopodia brevicornis

Amphiascopsis cinctus

Tisbe holothuriae
Bulbamphiascus imus

Ameira parvula

Orthopsyllus cf. linearis

Stylicletodes longicaudatus

Laophonte cornuta

Laophonte cf. inornata

2. WARM TEMPERATE \& TROPICAL (CIRCUMTROPICAL):

Amphiascus hirtus

Robertsonia propinqua

Amonardia perturbata

Typhlamphiascus unisetosus

Amphiascoides nichollsi

Ameira minuta

3. ANTIBOREAL \& ANTARCTIC

Ectinosoma australe

Harpacticus pulvinatus

Harpacticus furcatus

Tigriopus angulatus

Zausopsis contractus

Zausopsis mirabilis

Scutellidium plumosum

$\underline{\text { Scutellidium armatum }}$

4. ENDEMIC

Scutellidium spinatum

Porcellidium dilatatum

Porcellidium erythrum

Porcellidium sp. nov.

Porcellidium sp. nov.

Porcellidium sp. nov.

Porcellidium sp. nov.
Phyllopodopsyllus cf. minor

Laophonte cornuta nigrocincta

Laophonte cf. sima

Heterolaophonte cf. longifurcata Lourinia armata

Scutellidium macrosetum Alteutha littoralis Diarthrodes cf. imbricatus Dactylopodia cf. frigida Amphiascopsis south-georgiensis Mesochra flava

Paralaophonte meinerti

Idomene novae-zealandiae Amphiascus lobatus Bulbamphiascus sp. nov. Amphiascoides sp. nov. Paramphiascella sp. nov. Enhydrosomella sp. nov. Heterolaophonte sp. nov. 
45.

TABLE 4 - Cont'd.

4. ENDEMIC CONT'D.

Alteutha sp. nov.

Eupelte regalis

Neopeltopsis pectinipes

Parathalestris sp. nov.

Paralaophonte sp. nov.

Harpacticus sp. nov.

Coullia sp. nov.

Coullia sp. nov.

Laophontodes hamatus

Harpacticus sp. nov.

Laophontodes sp. nov. 
Large gaps still exist within our knowledge of the world-wide distribution of meiobenthic organisms. Attempts must be made, however, to broaden and coordinate distribution data before a rationalization of the zoogeography of this group can be made (see Wells 1967; Coull \& Herman 1970). Logical frameworks of zoogeographic information may thus evolve.

Of the 66 species and 1 variety of harpacticoids collected during the present study (Table 3), there are 9 new records for the southern hemisphere and 30 species are new records for the New Zealand region. Twenty-five species (38\%) have not yet been recorded elsewhere and at this stage are considered to be endemic to New Zealand (Table 4). The remaining 26 non-endemic elements excluding the 11 cosmopolitan species, are almost equally divided into Warm Temperate - Tropical (this region accounts for 11 species) and the cooler Southern Temperate and Antarctic forms (15 species) and is further evidence for the rather transitional nature of the central New Zealand marine biota (Knox 1960). Disjunct distribution patterns appear in the present fauna and fall into two groups: a). species which are otherwise so far known to occur only in Europe (Stylicletodes longicaudatus, Paradactylopodia brevicornis, Ameira minuta) and b). species otherwise found only in California (Amonardia perturbata, Typhlamphiascus unisetosus, Heterolaophonte cf. longifurcata). As more work in this field is completed it is possible that such records will in time be considered cosmopolitan.

A literature survey has revealed that of the 96 species of Harpacticoida recorded from the South Atlantic (i.e. Patagonia, Islands of the South Atlantic, East Antarctica - 
Lang 1948, Wiborg 1964, Pallares 1966, 1968, 1969, 1970, 1973a, b), 23 are also found in New Zealand. Omitting the cosmopolitan and circumtropical species, 14 species (17\%) occur in the Magellanic region and New Zealand. A similar analysis of the south-eastern Australian (Nicholls 194la, b, Hamond 1971, 1973a, b, c, d, e) and southern African fauna (Lang 1948, Kunz 1963,'Branch 1974, 1975) reveals 4 species (6\%) from Australia and 5 species (7\%) from southern Africa (Fig. 7). The affinities of the New Zealand littoral harpacticoids so far defined are therefore clearly with the South American region. Added to this are the apparent relationships between many of the endemic New Zealand species and South American forms e.g. Scutellidium spinatum, Porcellidium dilatatum, $\underline{P}$. erythrum and Eupelte regalis show close affinities with $\underline{S}$. ringueleti Pallares, $\underline{\text { P. tristanense }}$ Wiborg, P. rubrum Pallares, and E. tristanensis Wiborg respectively (Hicks 1971). Branch (1975) has found $\underline{\mathrm{s}}$. ringueleti near Cape Town, and also describes a new species S. macrosetum which is closely allied to the South Atlantic S. armatum (Wiborg). The contemporary faunal relationships of India are largely with Africa, as would be expected from the adjacent position of these two land masses. The Chatham Island species onychocamptus chathamensis (Sars) is shared with the Cape of Good Hope and Calcutta (Lang 1948:1419) and has recently been located in Sydney and Melbourne (Hamond pers. comm.). It is probable that this species will ultimately be collected from the N.Z. mainland. The congeneric Indian species O. bengalensis (Sewell) has now also been located in Australia (Bayly 1970, Hamond 1973c). An Indian affinity with Mesochra meridionalis is also evident but Hamond (1971) is doubtful of the status of this species. 
48.

6

FIG. 7 - Southern hemisphere zoogeographic relationships of the New Zealand marine Copepoda (Harpacticoida). 


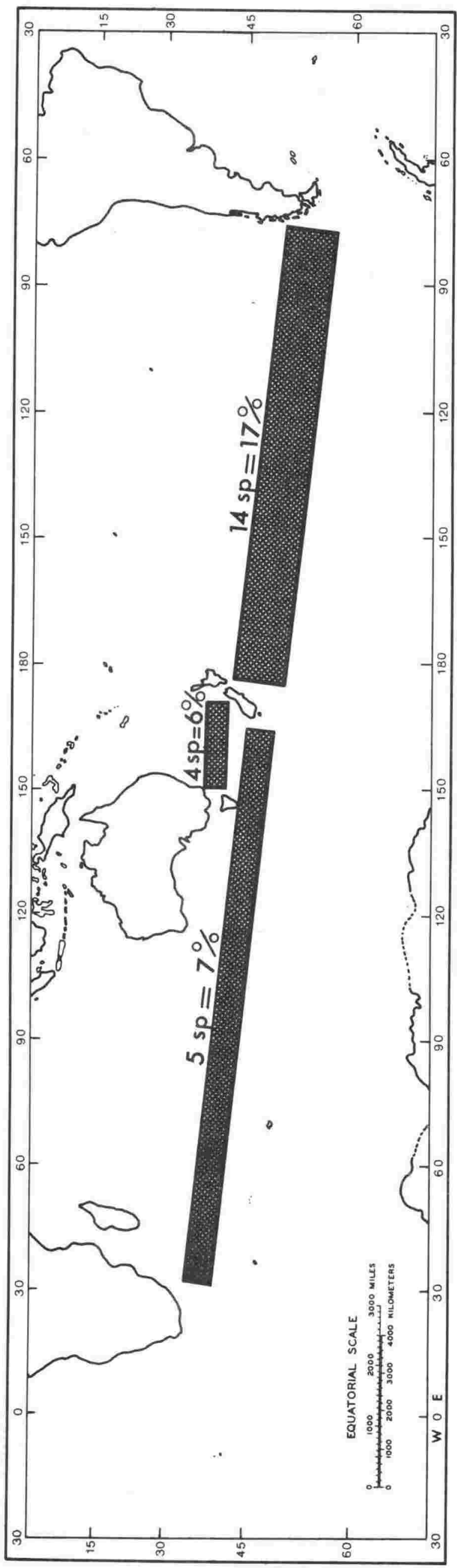


In view of the close relationship between the South Australian and New Zealand seaweed flora (Knox 1963) and the apparent preference of some harpacticoid copepods for particular seaweeds (Hicks in press a, Table 7; c), the discontinuous distribution of seaweed dwelling harpacticoids appears in the first instance to be best explained by the theory of knox \& Lowry (in press). This suggests that longterm circumpolar epipelagic drift (in the West Wind Drift) is the means of contemporary dispersal of gammaridean amphipods. These authors note an exponential decrease in the number of species occurring at each location as the circumpolar distance eastward from the Magellanic area of maximum speciation increases. The source of colonizing species appears to be the nearest neighbour to the west, thus Australia is an important donor to New Zealand by dispersal of fauna on floating algae or by larval drift (Finlay, Fell, in Knox 1963, Knox \& Lowry in press).

In order for this dispersal mechanism to be primarily responsible for present faunal patterns one would therefore expect the harpacticoid fauna of South Australia and New Zealand to be closely related. However, this present analysis reveals a rather low degree of affinity (6\%) between the New Zealand and South Australian Harpacticoida (Fig. 7). Ecologically specialized seaweed dwelling copepods are probably poorly adapted to cross large ocean barriers by rafting on drifting objects. This is also the case with the interstitial meiofauna (Sterrer 1973). The harpacticoids associated with characteristically widely distributed floating algae such as Sargassum (e.g. Scutellidium longicauda (Philippi), Dactylopodia tisboides (Claus), Paralaophonte congenera (Sars) - see Yeatran 
1962), are largely eurytopic cosmopolitan species capable of withstanding wide fluctuations in environmental variables and are thus eminently suitable as trans-oceanic migrants. Most other littoral seaweeds, however, do not float when detached from rocky substrates, but quickly sink to form 'benthic drift weed'. Such detached algae begin to autolyse as they sink and hence become unattractive to the fauna normally associated with attached healthy plants (Hicks in press c). Therefore, the likelihood of such seaweeds being widely transported and carrying a diverse associated fauna is slight. It is suggested that fortuitous dispersal of small numbers of species, such as those on Sargassum or Macrocystis, plays little part in the establishment of large diverse copepod assemblages of the disjunctive nature seen in the contemporary fauna of the southern continents.

The present data (p. 47) show that the harpacticoid faunas of New Zealand and South America are closely related but affinities between New Zealand and Australia and New Zealand and Southern Africa are far less distinct (Fig. 7). This pattern exhibits similar correlations with those found by Brundin (1965, 1966, i975) for the southern continental relationships of chironomid midges, and is also consistent with sterrer's (1973) suggestion that plate tectonics is the mechanism responsible for the present day distribution of much of the interstitial fauna.

It therefore seems likely that these 'transantarctic relationships' of harpacticoids developed while the southern landmasses were directly connected along the circum-Pacific orogenic belt. This region has possibly acted as an important area of evolution and diversification for the early non-pelagic 
Copepoda, from which considerable initial dispersal took place. The ancestral stock of the southern hemisphere Harpacticoida possibly could have migrated along the seaward side of the 'Gondwanide anticline' (see Sewell 1956: figs 2 and 10), and subsequently carried to their present locations by postCretaceous drifting of the various landmasses. New Zealand probably received its fauna via the coastlines of South America and Western Antarctica, while S. Africa and S. Australia received their members via East Antarctica (see Brundin 1975). Furthermore the Tasman sea has consequently acted as an effective contemporary barrier to migrations of harpacticoids from Australia to New Zealand.

The relatively high affinities at the specific level could indicate slow rates of evolution and allopatric speciation after separation of the original stock. Similar tendencies are noted by Frost \& Fleminger (1968:87) in the calanoid copepod genus Clausocalanus where relative differences are stronger between pairs of extensively sympatric species than between species that occur together in only a small part of their ranges.

Future additions to faunal lists will undoubtedly make a vast difference to the above pattern. Such studies also may help to clarify the concept of plate tectonics as the main mechanism responsible for contemporary copepod distribution. There is a need for a new look at many of the southern hemisphere and tropical disjuncts that some authorities (e.g. Sewell 1956) have used as 'proofs' of former continental connections. These analyses should take into account, in addition to taxonomic and phylogenetic relationships, dispersal capacities, and ecological tolerances of this group. 


\section{POSTSCRIPT}

Recent papers by Pallares (1975: Physis 34: 67-83; 213-227) include new records and descriptions of 14 harpacticoids from the Ria Deseado, Argentina. Seven species are new, while the other seven may be considered cosmopolitan in their distribution. Although they contain the first authenticated southern hemisphere record of Stylicletodes longicaudatus (Brady \& Robertson) (p.223), these recent contributions do not justify any modification to the levels of affinity noted above (p.47).

\section{DISCUSSION}

RELATIONSHIP OF HARPACTICOID FAUNA TO ALGAE

To determine the degree of relationship between the harpacticoid fauna of the six algae, a matrix of affinity was constructed. The similarity matrix makes use of all data based on the percentage of co-occurrence, namely:

\section{$\frac{\text { Actual co-occurrence }}{\text { Possible co-occurrence }} \times 100$}

Faunal associations are thus calculated from every possible combination of faunal pairs with a total occurrence of over 5 individuals (see Hicks in press a, Table 7 ). Overvaluing of rare species relative to dominant species is therefore restricted.

This analysis has been used in preference to other indices of similarity for the following reasons. In view of the fact that algal surface areas differ, total sample sizes must vary between respective algae. Analyses such as Jaccard's (1902) Coefficient of Similarity and the Quotient of similarity technique of Sorenson (1948) were therefore disregarded because of their dependence on constant sample size. The Index of 
Similarity method of Mountford (1962) while being relatively independent of sample size was also discarded due to the nature of the present samples. All algae have relatively few species but usually 2 or 3 dominants in terms of numbers of individuals. Use of such an index can be misleading in cases where two very similar samples consist predominantly of the same dominant species but have minor species not in common. Two such samples would show little similarity.

Midtidal Corallina and subtidal Pterocladia show the highest degree of faunal association (44\%) than combinations of other species (Fig. 8). The importance and effect of deposited sediments on the diversity and abundance of algal fauna has been discussed previously (Dahl 1948, Wieser 1959, Hagerman 1966, Moore 1972). Sheltered conditions and finely branched algae appear as necessary prerequisites for the entrapment and deposition of suspended organic and terrigenous material.

In this case both algae have a branching structure of high surface area and in being subject to tidal influence, have a greater potential for accumulating and retaining sediments (Table 1). Deposited material is not retained on other subtidal algae (Table 1) which are less foliaceous (represented by lower surface areas) but which are nevertheless subjected to wave turbulence and strong tidal currents. Thus algae of higher surface area increase the propensity and rate of sediment accumulation irrespective of tidal level. However, since accumulation of sediments is an expression of the average water movement (Enequist 1950), extremes of deposition are more clearly observed in sheltered conditions. In this case sheltered midlittoral pool Corallina retains high levels of sediment and 
54.

FIG. 8 - Matrix of affinity based on percentage co-occurrence of the total annual harpacticoid fauna from the six algae studied. Species with an annual occurrence of less than 5 individuals have been omitted. 


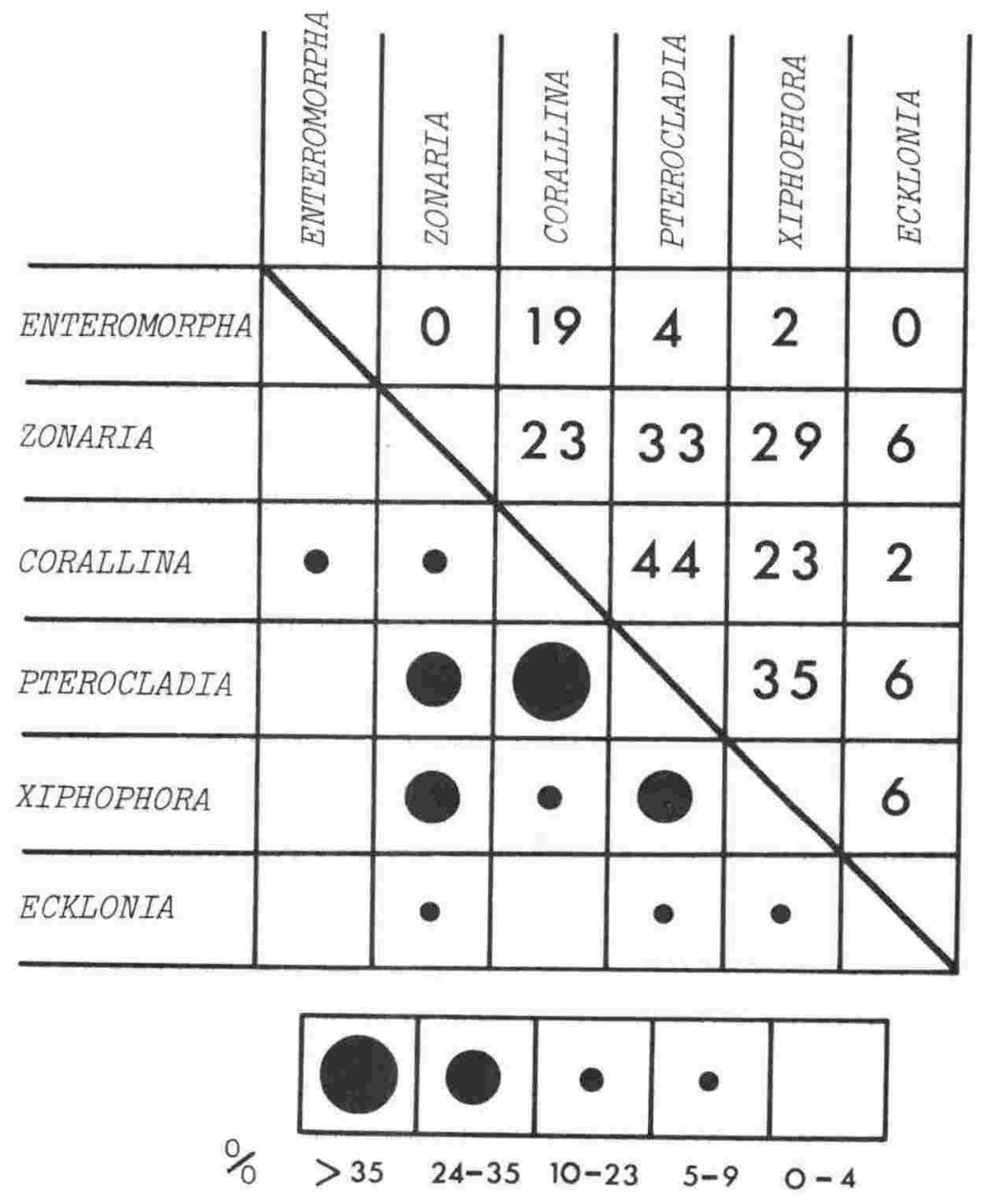


consequent faunal diversification is evident (Hicks in press a, Table 7). Sediment levels on Pterocladia, although noticeably lower than Corallina due to greater subtidal turbulence, allow a foothold for a number of species preferring a certain amount of sediment. Such species are therefore common to both algae and increase the between algae faunal affinity.

\section{CONTRIBUTION OF HARPACTICOIDS TO TOTAL ALGAL MEIOBENTHOS}

To evaluate the contribution and relative importance of harpacticoids to the entire algal meiobenthos, complete enumeration of the meiofauna was made from samples taken in midwinter (July 1973, Table 5) and midsummer (January 1974, Table 6). It should be noted that although these samples were taken at the above times, the figures do not necessarily reflect the annual minimum and maximum densities for respective algae (see Hicks in press a). These results merely serve to indicate the degree of relativity between the constituent meiofaunal groups.

With the exception of Pterocladia and Ecklonia harpacticoids constituted the dominant taxon on all algae (Tables $5 \& 6$ ). Numerically, harpacticoids account for over $37 \%$ of the cumulative meiofauna from all six algae. Ostracods were dominant over harpacticoids on Pterocladia in the summer (Table 6) with the converse in winter (Table 5). Gastropods, nematodes and ostracods were more important components on Ecklonia in both samples. Summer analysis of Zonaria showed the highest relative proportion of copepods $(67 \%)$ to other groups, and this is composed mainly of a single species (Porcellidium dilatatum, see Hicks in press a). In general, harpacticoid copepods were the most abundant meiofaunal organisms followed by ostracods and nematodes. 
56.

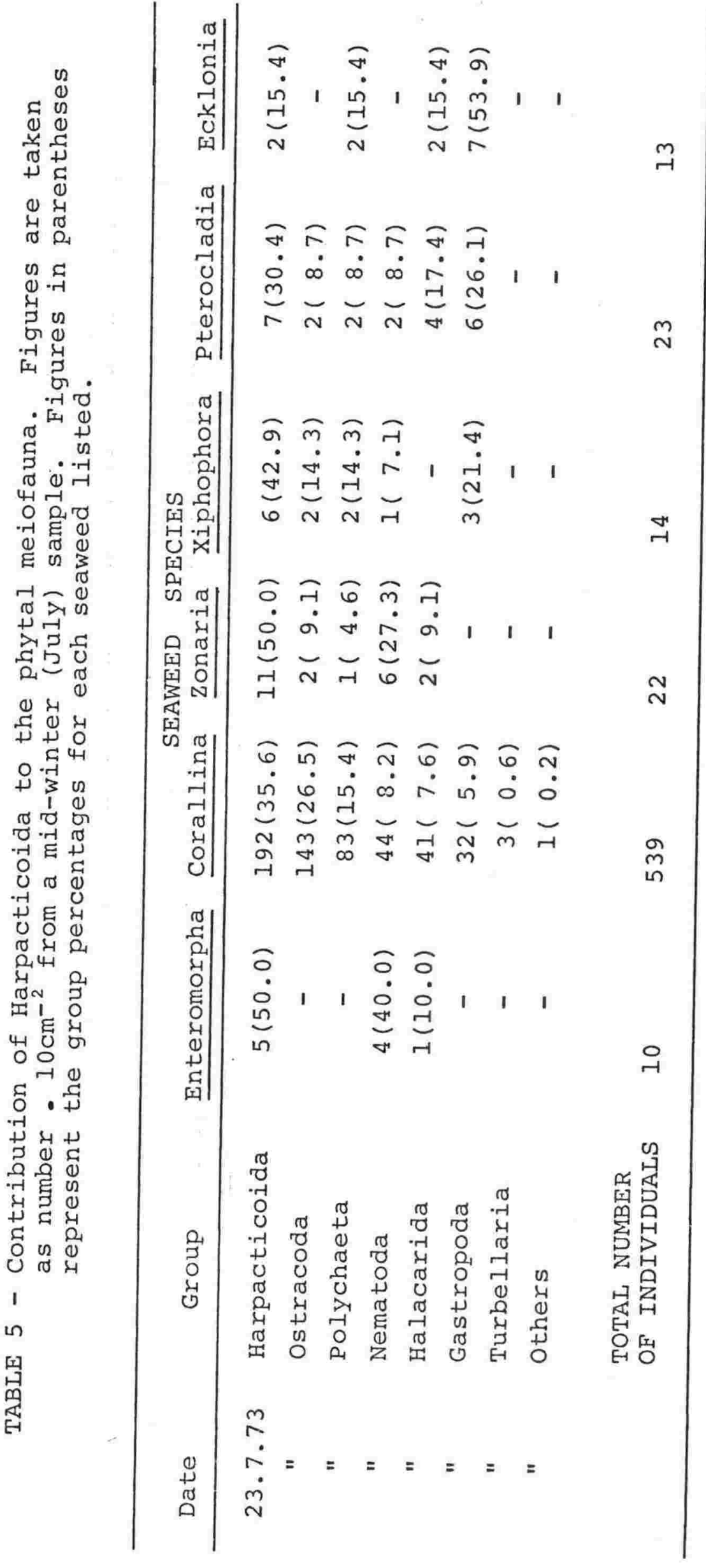


0

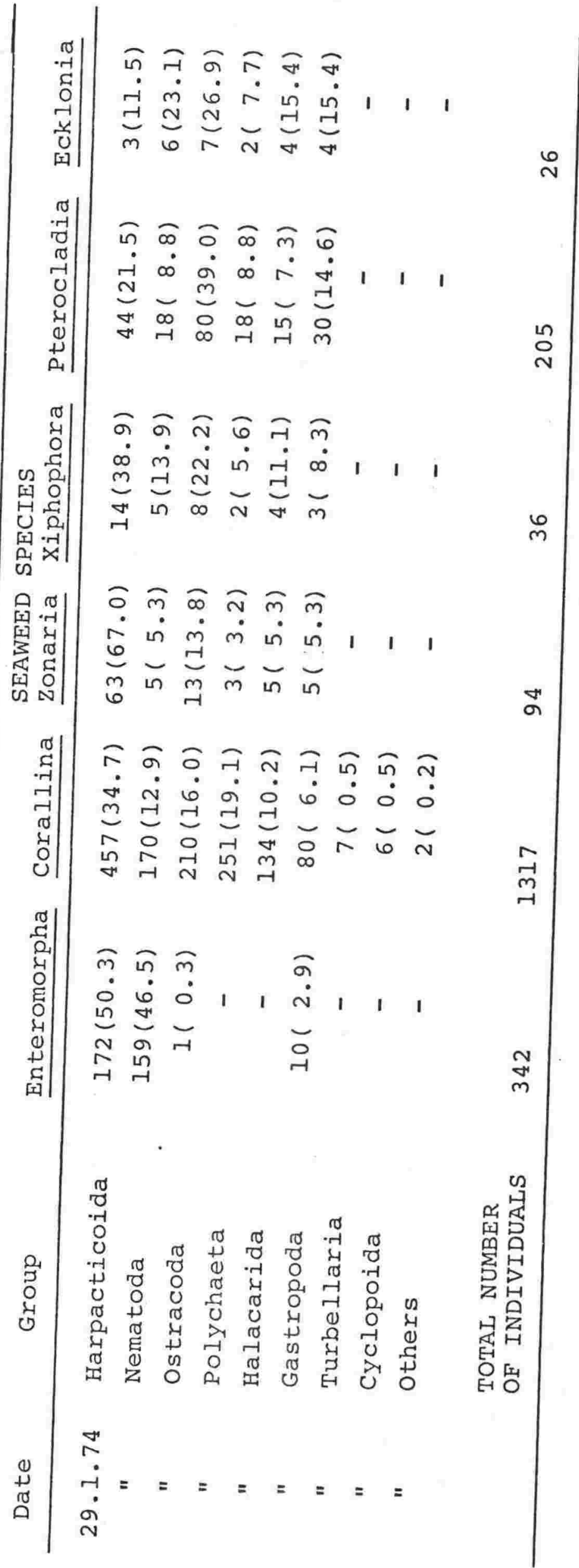


58.

While nematodes remain numerically the most significant group in semi-estuarine sea-grasses with high levels of deposited muddy sediments and detritus (Kikuchi 1967), cleaner macrophytes in more saline regions tend to be dominated by rather more mobile taxa such as copepods, ostracods and mites. Hagerman (1966) reported a mean annual ostracod composition of over $37 \%$ on $\varnothing$ resund Fucus while benthonic copepods only comprised $28 \%$ at their maximum abundance. Ohm's (1964) account of the meiofauna on Fucus in the Bay of Kiel indicates a eulittoral fauna chiefly composed of halacarids. On the other hand sublittoral Fucus supported mostly nematodes, but in winter harpacticoids contributed to $60 \%$ of the fauna. Mukai (1971) found the copepods on Sargassum to be the most important constituent of the phytal meiofauna, comprising over $50 \%$ throughout the year. Indeed the greater abundance of clinging, crawling copepods and ostracods compared with nematodes on algae is in marked contrast to the meiofaunal composition of sandy and muddy shores where, in general, nematodes predominate.

COMPARISON WITH LEVEL-BOTTOM MEIOBENTHOS

Comparison of the mid-winter and mid-summer total phytal meiobenthos densities (Tables $5 \& 6$ ) with those of inorganic level-bottom sediments is presented in Tables 7 \& 8 . References included in these tables largely postdate McIntyre's (1969) review and should be considered along with his comprehensive listings.

In the intertidal zone (Table 7) the sand and phytal biotopes are comparable not only in terms of copepod density, but also with regard to the density of the total meiobenthos. Accumulated medium grade sandy sediments in corallina undoubtedly influences faunal composition and density in a way similar to 


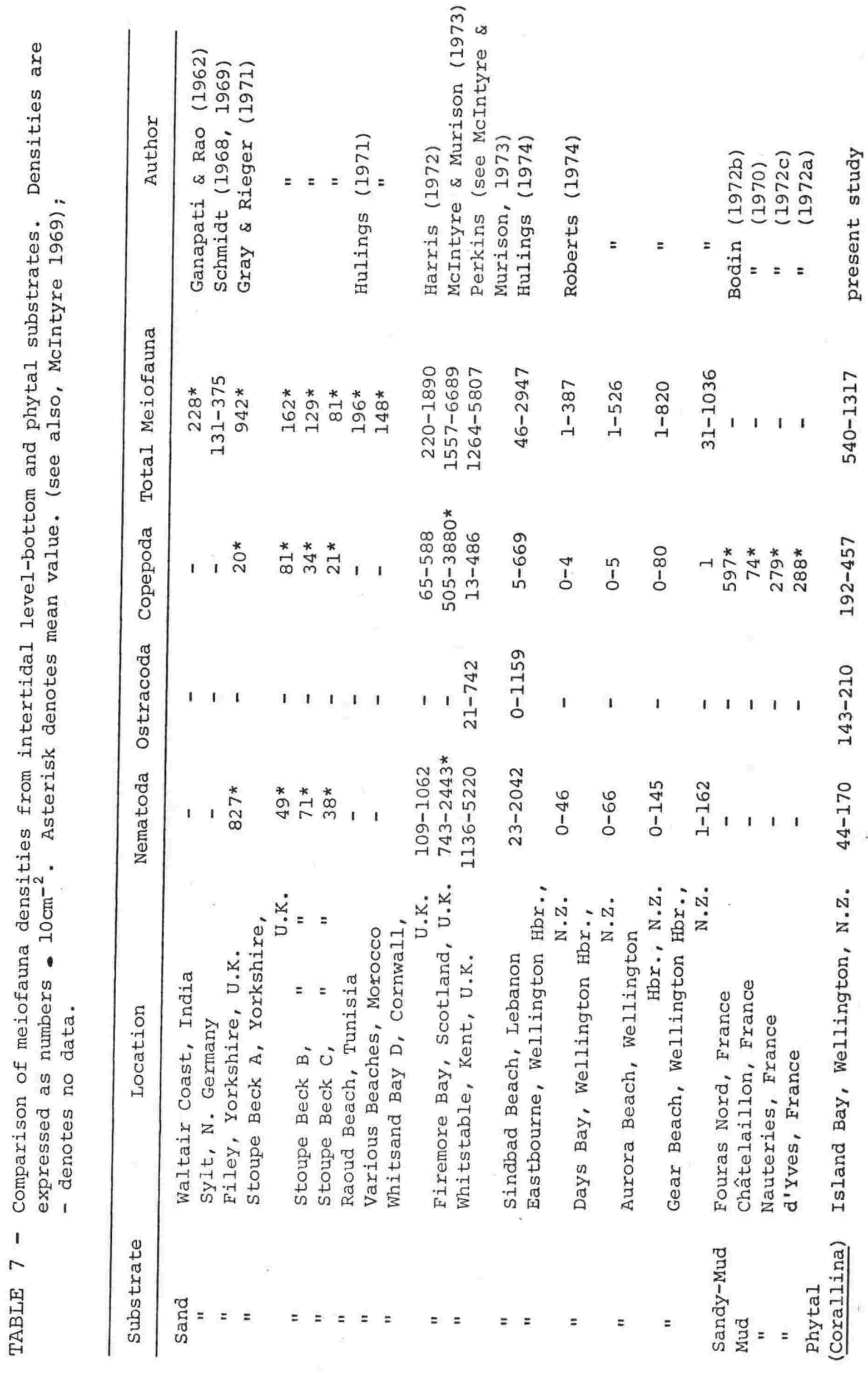


60.

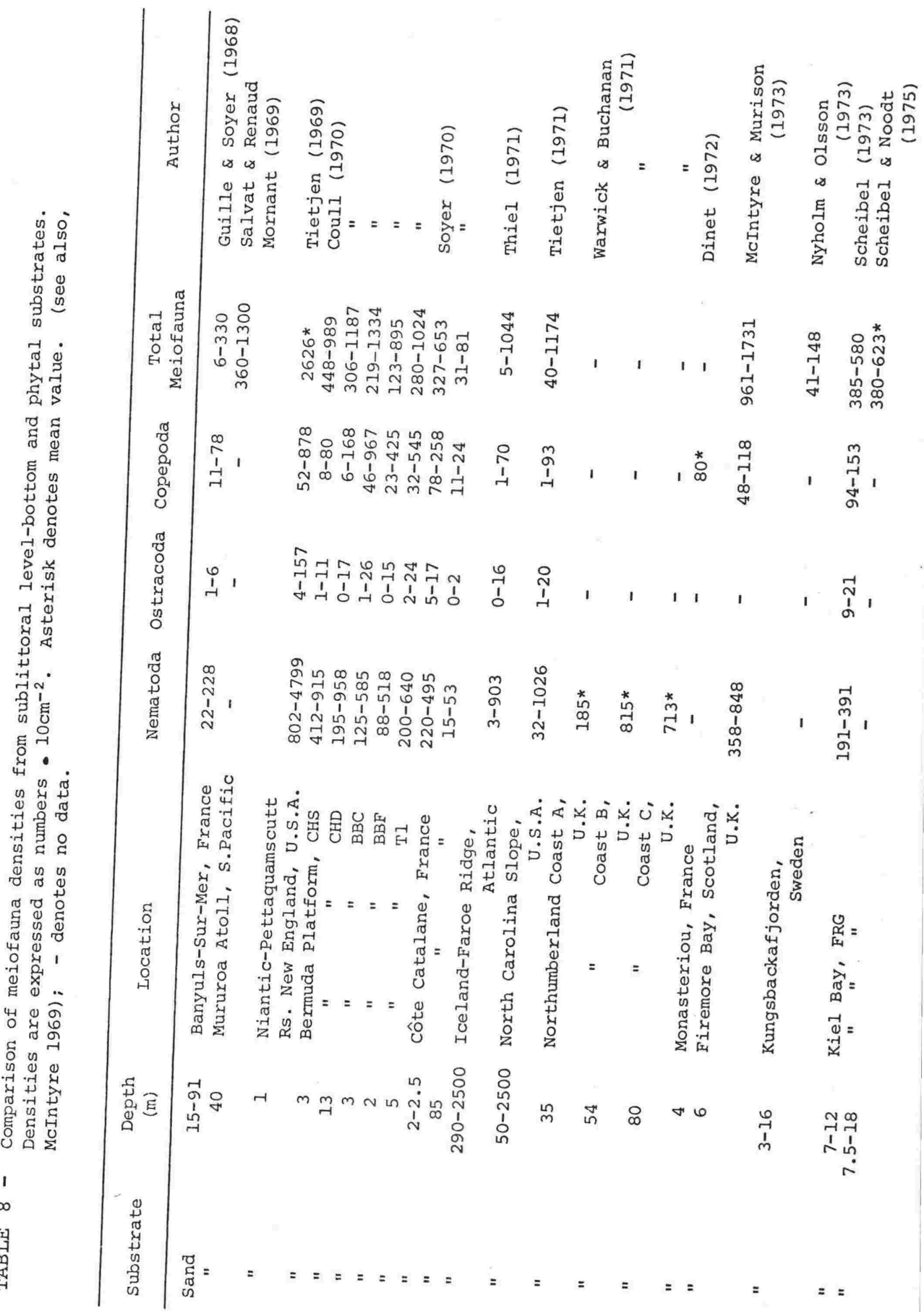




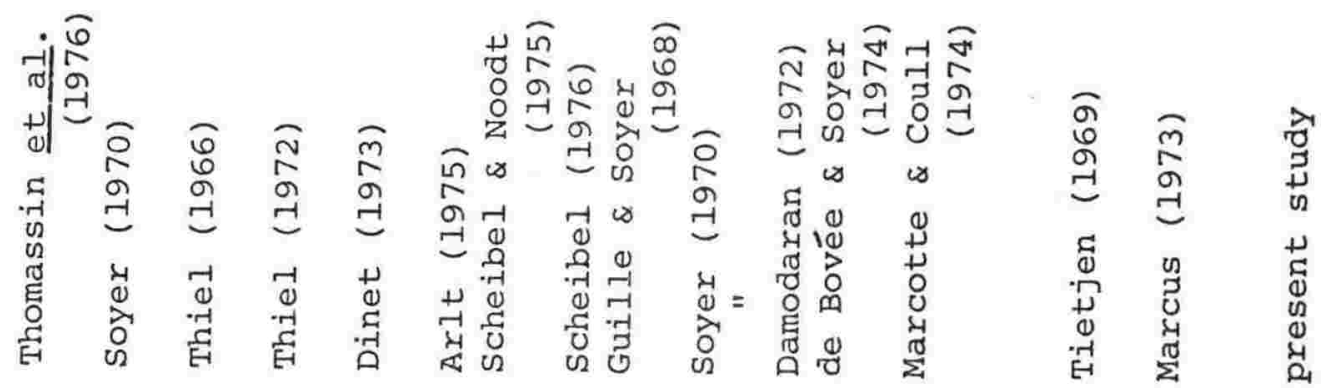

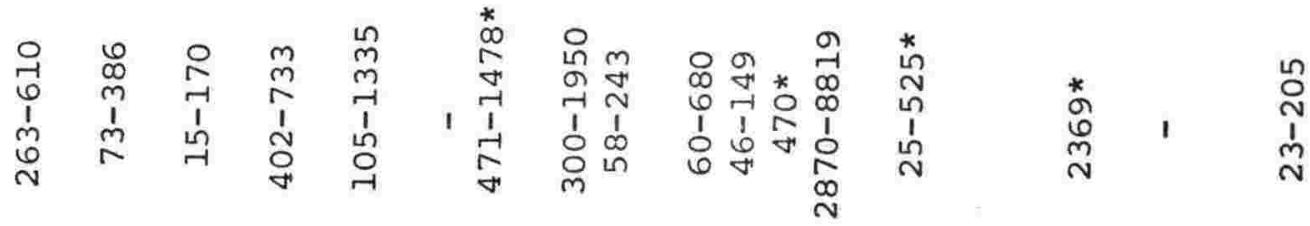

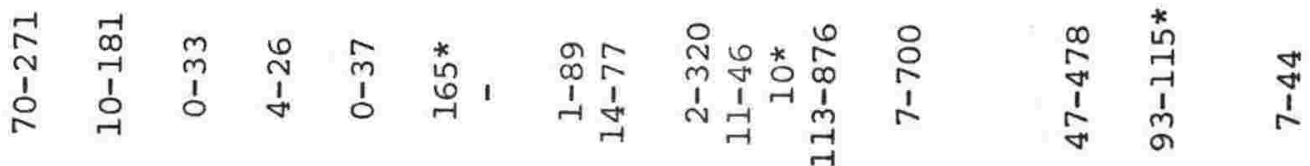

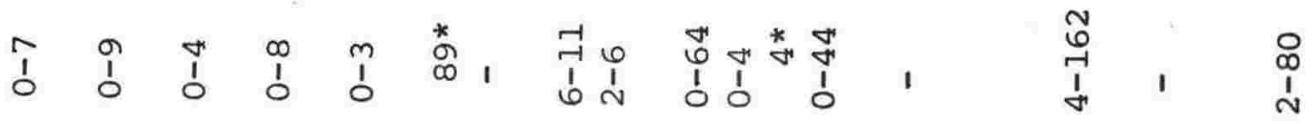

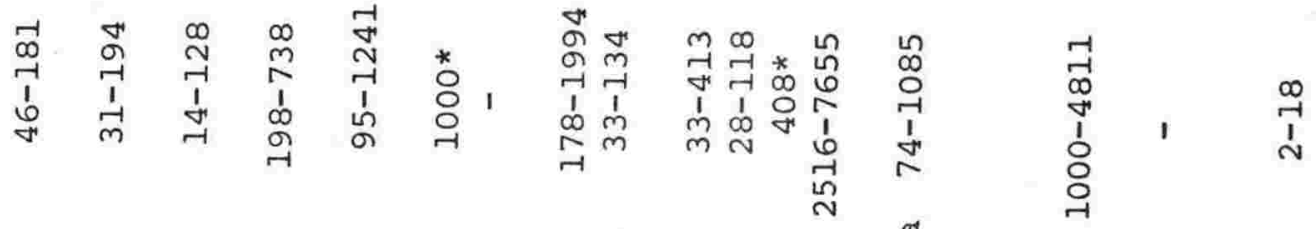

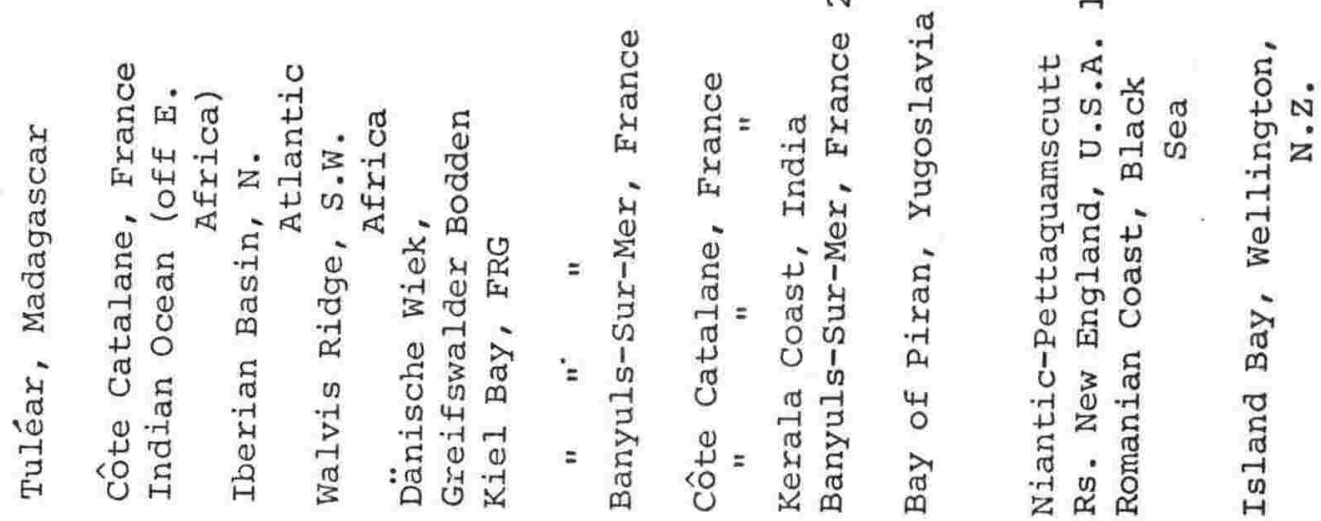

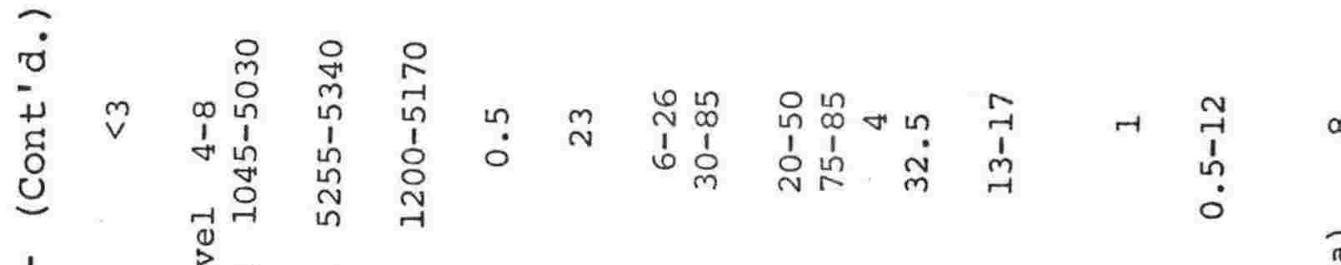

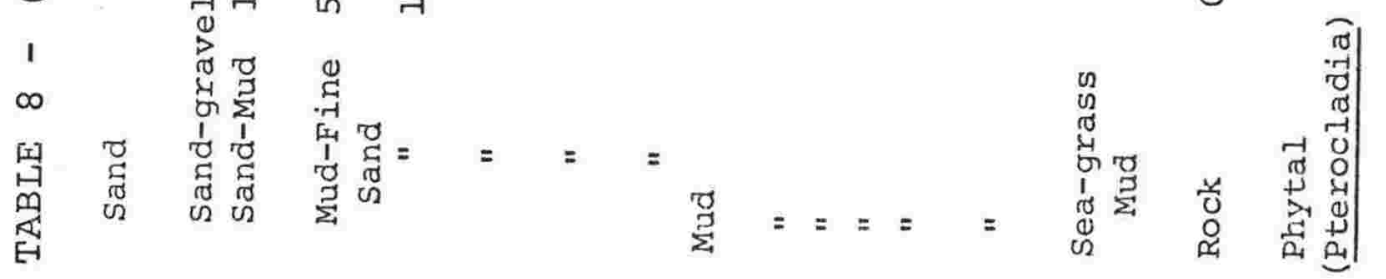


pure sandy substrates elsewhere. Intertidal muddy bottoms tend to be richer in both total meiofauna and copepod density. This is because most intertidal muddy bottoms are located in estuaries which, in general, have a higher productivity than fully marine localities.

Although there is some variation in meiofauna densities reported from shallow marine bottoms (due partially to variations in sampling and extraction techniques of different authors), the evidence to date suggests that meiofauna densities decrease significantly with increasing depth (see however, de Bovée \& Soyer 1974 - Table 8). Algal-dwelling meiofauna are consistent with this trend, total population density being up to six and a half times lower than in the intertidal. Generally lower surface areas of these subtidal algae which influences directly the available space utilized by meiofauna, results in depressed population densities. Sublittoral sands, in general, contain higher densities of copepods than both the phytal and muddy bottoms, but in terms of total population density muddy substrates harbour the greatest overall abundance of meiofauna.

\section{ACKNOWLEDGEMENTS}

The first year of this investigation was supported by a U.G.C. Postgraduate Scholarship and forms part of a Ph.D. thesis presented at Victoria University of Wellington. I wish to extend my gratitude to Dr R.G. Wear, Professor J.B.J. Wells (Zoology Dept. Victoria University) and Dr J.M. Bradford (N.Z. Oceanographic Institute) for their constructive comments on the text. I thank Dr R. Hamond (Zoology Dept. Melbourne 
University) who via much correspondence has assisted greatly in the confirmation of many of my species identifications. I am grateful to the N.Z. Meteorological Service for provision of their climatological data. The help given by Miss N.M. Adams (National Museum) in algal identifications and $\mathrm{Mr} \mathrm{W}$. Armstrong (Mathematics Dept., Victoria University) with my statistical problems, is much appreciated.

\section{LITERATURE CITED}

ADAMS, N.M. 1972: The marine algae of the Wellington area. A list of species. Records of the Dominion Museum

ARLT, G. 1975: Remarks on indicator organisms (meiofauna) in the coastal waters of the GDR. Merentutkimuslaitos Julkaisuja/Havsforskningsinstitutets 239: 272-279.

BARTLE, J.A. 1972: The distribution and abundance of Euphausiids in Cook Strait. Unpublished M.Sc. thesis, Zoology Department, Victoria University of Wellington: $169 \mathrm{pp}$.

1974: Seabirds of eastern Cook Strait, New Zealand, in autumn. Notornis 21: 135-166.

BAYLY, I.A.E. 1970: Further studies on some saline lakes of south-east Australia. Australian Journal of Marine and Freshwater Research 21: 117-129.

BAYLY, I.A.E. \& WILLIAMS, W.D. 1966: Chemical and biological studies on some saline lakes of south-east Australia. Australian Journal of Marine and Freshwater Research

BODIN, P. 1967: Catalogue des nouveaux Copépodes Harpacticoides marins. Mémoires du Muséum National D'Histoire Naturelle (Sér. A) 50: 1-76.

1970: Copépodes Harpacticoïdes marins des environs de la Rochelle. 1-Espèces de la vase intertidale de Châtelailion. Tethys 2: 385-436.

1971: Catalogue des nouveaux Copépodes Harpacticoides marins. Additif No. 1. Tethys 2: 881-907.

1972a: Copépodes Harpacticoïdes marins des environs de la Rochelle. 2-Espèces de la zone intertidale d'Yves. Tethys 3: 411-433. 
1972b: Copépodes Harpacticoïdes marins des environs de la Rochelle. 3-Espèces de la zone intertidale de Fouras-Nord. Tethys 3: 841-864.

1972c: Copépodes Harpacticoǐdes marins des environs de la Rochelle. 4-Espèces de la zone intertidale des Nauteries. Tethys 4: 651-682.

BOISSEAU, J -P. 1957: Technique pour l'étude quantitative de la faune interstitielles des sables. Congrès national des sociétés savantes de Paris et des départements. Section des sciences. Compte rendu: 117-119.

BOVEE, F. de, COINEAU, N., SOYER, J. \& TRAVÉ, J. 1973: Sur l'existence d'une faunule interstitielle littorale dans l'Archipel de Kerguelen (Terres Australes et Antarctiques françaises). Académie des sciences. Paris. Compte ren̉du hebdomadaire des sciences 276: 1041-1044.

BOVÉE, F. de \& SOYER, J. 1974: Cycle annuel quantitatif du méiobenthos des vases terrigènes côtières.

Distribution verticale. Vie et Milieu 24: 141-157.

BRADFORD, J.M. 1972: Systematics and ecology of New Zealand Central East Coast plankton sampled at Kaikoura. N.Z. Oceanographic Institute Memoir No. 54: 89pp.

BRADY, G.S. 1899: On the marine Copepoda of New Zealand. Transactions of the Zoological Society of London 15:

BRANCH, G.M. 1974: Scutellidium patellarum n.sp., a harpacticoid copepod associated with Patella spp. in South Africa, and a description of its larval development. Crustaceana 26: 179-200.

1975: A new species and records of Scutellidium (Copepoda Harpacticoidea) from South Africa, and a world key to the genus. Annals of the South African Museum 66: 221-232.

BRODIE, J.W. 1953: Stratigraphy and structure of the greywackes and argillites on the south coast of Wellington Peninsula. N.Z. Journal of Science and Technology 34: 205-226.

BRUNDIN, L. 1965: On the real nature of Transantarctic relationships. Evolution 19: 496-505.

1966: Transantarctic relationships and their significance, as evidenced by chironomid midges with a monograph of the subfamilies Podonominae and Aphroteniinae and the austral Heptagyiae. Kungl. Svenska Vetenskapsakademiens Handiingar il: $\frac{1-472}{1-}$

1975: Circum-Antarctic distribution patterns and continental drift. Mémoires du Muséum National D'Histoire Naturelle (Sér. A) 88: 19-28. 
COULL, B.C. 1970: Shallow water meiobenthos of the Bermuda Platform. Oecologia (Berl.) 4: 325-357.

COULL, B.C. \& HERMAN, S.S. 1970: Zoogeography and parallel level-bottom communities of the meiobenthic Harpacticoida (Crustacea, Copepoda) of Bermuda. Decologia (Berl.) 5: 392-399.

DAHL, A.L. 1969: The effect of environment on growth and development of Zonaria farlowii. Proceedings of the International seaweed symposium 6: $123-132$.

DAHL, E. 1948: On the smaller Arthropoda of marine algae, especially in the polyhaline waters off the Swedish west coast. Dissertation, Lund. Undersökningar över Öresund 35: 1-193.

DAMODARAN, R. 1972: Meiobenthos of the mudbanks of Kerala Coast. Proceedings of the Indian National Science Academy 38: 288-297.

DINET, A. 1971: Copepodes Harpacticoides d'un sable fin organogène des environs de Marseille. Tethys 2: 747-726.

1972: Étude écologique des variations quantitatives annuelles d'un peuplement de Copepodes Harpacticoides psammiques. Tethys 4: 95-112.

1973: Distribution quantitative du méiobenthos profond dans la région de la dorsale de walvis (SudOuest Africain). Marine Biology 20: 20-26.

ENEQUIST, P. 1950: Studies on the soft-bottom amphipods of the Skaggerak. Zoologiska bidrag från Uppsala 28: 299-492.

FAST, A.W. 1970: An evaluation of the efficiency of zoobenthos separation by sugar flotation. Progressive Fish Culturist 32: 212-216.

FROST, B. \& FLEMINGER, A. 1968: A revision of the genus Clausocalanus (Copepoda:Calanoida) with remarks on distributional patterns in diagnostic characters. Bulletin. Scripps Institution of Oceanography 12: $1-235$.

GABITES, J.F. 1960: Climate of Wellington. In "Science in Wellington," O'CONNOR, M. (ed). Royal Society of New Zealand: 33-35.

GANAPATI, P.N. \& RAO, G.C. 1962: Ecology of the interstitial fauna inhabiting the sandy beaches of Waltair coast. Journal of the Marine Biological Association of India 4: 44-57.

GARNER, D.M. 1961: Hydrology of New Zealand coastal waters, 1955. N.Z. Oceanographic Institute Memoir No. 8: $85 \mathrm{pp}$. 
GILMOUR, A.E. 1960: The hydrology of Cook strait and Wellington Harbour. In "Science in Wellington," O'CONNOR, M. (ed). Royal Society of New Zealand: 30-32.

GRAY, J.S. \& RIEGER, R.M. 1971: A quantitative study of the meiofauna of an exposed sandy beach, at Robin Hood's Bay, Yorkshire. Journal of the Marine Biological Association of the United Kingdom 51: 1-19.

GUILLE, A. \& SOYER, J. 1968: La faune benthique des substrats meubles de Banyuls-Sur-Mer. Premières données quantitatives et qualitatives. Vie et Milieu 19: 323-359.

GURNEY, R. 1927: Zoological results of the Cambridge expedition to the Suez Canal, 1924. 33. Report on the Crustacea: Copepoda (littoral and semi-parasitic). Transactions of the Zoological Society of London 22: 4 51-578.

HAGERMAN, L. 1966: The macro- and microfauna associated with Fucus serratus L., with some ecological remarks. Ophelia 3: 1-43.

HAMOND, R. 1970: On a harpacticoid copepod of the genus Orthopsyllus Brady \& Robertson from west Runton, Norfolk, England. Crustaceana 18: 209-217.

1971: The Australian species of Mesochra (Crustacea: Harpacticoida), with a comprehensive key to the genus. Australian Journal of Zoology Supplement No. 7: 1-32.

1973a: Robertgurneya smithi nov. sp. (Crustacea; Harpacticoida), with notes on other species of the genus. Journal of Natural History 7: 65-76.

1973b: Four new copepods (Crustacea: Harpacticoida, Canuellidae) simultaneously occurring with Diogenes senex (Crustacea: Paguridea) near Sydney. proceedings of the Linnean Society of New South Wales 97: 165-201.

1973c: The harpacticoid copepods (Crustacea) of the saline lakes in southeast Australia, with special reference to the Laophontidae. Records of the Australian Museum 28: 393-420.

1973d: The Australian species of Robertsonia (Crustacea, Harpacticoida), with a $\overline{\text { revised key }}$ to the genus. Records of the Australian Museum 28: $421-435$.

1973e: Australonannopus aestuarinus gen. nov., sp. nov. (Crustacea, Harpacticoida), an aberrant cletodid from Australian brackish waters. The Papers and Proceedings of the Royal Society of Tasmania 107: 239-245.

HARRIS, R.P. 1972: The distribution and ecology of the interstitial meiofauna of a sandy beach at whitsand Bay, East Cornwall. Journal of the Marine Biological Association of the United Kingdom 52: 1-18. 
HARROD, J.J. \& HALL, R.E. 1962: A method for determining the surface areas of various aquatic plants. Hydrobiologia 20: 173-178.

HEATH, R.A. 1970: An occurrence of low water temperatures on the north Canterbury coast (note). N.Z. Journal of Marine and Freshwater Research 4: 22 $3-226$.

1971: Hydrology and circulation in central and southern Cook Strait, New Zealand. N.Z. Journal of Marine and Freshwater Research 5: 17 $\overline{8-199 .}$

1972: The Southland Current. N.Z. Journal of Marine and Freshwater Research 6: 497-533.

1973: Present knowledge of the oceanic circulation and hydrology around New Zealand - 1971. Tuatara 20: $125-140$.

HEIP, C., SMOL, N. \& HAUTEKIET, W. 1974: A rapid method of extracting meiobenthic nematodes and copepods from mud and detritus. Marine Biology 28: 79-81.

HICKS, G.R.F. 1971: Some littoral harpacticoid copepods, including five new species, from Wellington, New Zealand. N.Z. Journal of Marine and Freshwater Research 5: 86-119.

(in press a): Ecological studies on marine algal-dwelling Copepoda (Harpacticoida). 2. Seasonal changes in population density; species occurrence and associations. N.Z. Journal of Marine and Freshwater Research.

(in press b): Ecological studies on marine algal-dwelling Copepoda (Harpacticoida). 3. Breeding activity. N.Z. Journal of Marine and Freshwater Research.

(in press c): Substrate preference of marine algal-dwelling Copepoda (Harpacticoida). Marine Biology.

HULINGS, N.C. 1971: A comparative study of the sand beach meiofauna of Lebanon, Tunisia and Morocco. Thalassia Jugoslavia 7: 117-122.

1974: A temporal study of Lebanese sand beach meiofauna. Cahiers de Biologie Marine 15: 319-335.

HULINGS, N.C. \& GRAY, J.S. (Eds.) 1971: A manual for the study of meiofauna. Smithsonian Contributions to Zoology 78: 1-83.

JACCARD, P. 1902: Lois de distribution florale dans la zone alpine. Société vaudoise des sciences naturelles. Bulletin 38: 69-130.

JANSEN, K.P. 1971: Ecological studies on intertidal New Zealand Sphaeromatidae (Isopoda: Flabellifera). Marine Biology 11: 262-285. 
KAJAK, Z. 1971: Benthos of standing water. IBP Handbook No. 17 - "A Manual on Methods for the assessment of Secondary Productivity in Freshwaters." EDMONDSON, W.T. \& WINBERG, G.G. (eds). Chap. 1: 25-65.

KIDSON, E. 1931: Mean temperatures in New Zealand. N.Z. Journal of Science and Technology 13: 140-153.

KIKUCHI, T. 1967: An ecological study on animal communities of the Zostera marina belt in Tomioka Bay, Amakusa, Kyushu. Amakusa Marine Biological Laboratory. Publications 1: 1-106.

KNOX, G.A. 1960: Littoral ecology and biogeography of the southern oceans. Proceedings of the Royal society of New Zealand B 152: 577-624.

1963: The biogeography and intertidal ecology of the Australasian coasts. Oceanography and Marine Biology Annual Review 1: $3 \overline{41-404 .}$

KNOX, G.A. \& LOWRY, J.K. (in press): A comparison between the benthos of the Southern Ocean and the North Polar Ocean with special reference to the Amphipoda and the Polychaeta. Proceedings SCOR/SCAR Polar Oceans Conference, Montreal, 1974.

KUNZ, H. 1963: Weitere Harpacticoiden (Crustacea Copepoda) von der südwestafrikanischen Küste. Zoologischer Anzeiger 171: 33-51.

KUNZ, H. \& KUNZ, G. 1973: Okologische untersuchungen an strandgewässern Südwestafrikas. Namib und Meer 4: 41-64.

LACKEY, R.T. \& MAY, B.E. 1971: Use of sugar flotation and dye to sort benthic samples. Transactions of the American Fisheries Society 100: 794-797.

LANG, K. 1934: Marine Harpacticoiden von der Campbell-Insel und einigen anderen südlichen Inseln. Acta Universitatis Lundensis. N.F. avd 2 Bd 30: 1-56.

1936: Copepodà Harpacticoida. Further Zoological Results of the Swedish Antarctic Expedition, 1901$19033: 1-68$.

1948: "Monographie der Harpacticiden." Hakan Ohlsson, Lund, 1683pp.

1965: Copepoda Harpacticoidea from the Californian Pacific Coast. Kungl. Svenska Vetenskapsakademiens Handlingar 10: 1-560.

LARKUM, A.W.D., DREW, E.A. \& CROSSETT, R.N. 1967: The vertical distribution of attached marine algae in Malta. Journal of Ecology 55: 361-371.

MARCOTTE, B.M. \& COULL, B.C. 1974: Pollution, diversity and meiobenthic communities in the North Adriatic (Bay of Piran, Yugoslavia). Vie et Milieu 24: 281-300. 
MARCUS, A. 1973: L'écologie des Copépodes du substrat rocheux. Travaux de la Muséum national d'histoire naturale "Grigore Antipa" 13: 89-100.

MCINTYRE, A.D. 1969: Ecology of marine meiobenthos. Biological Review 44: 245-290.

MCINTYRE, A.D. \& MURISON, D.J. 1973: The meiofauna of a flatfish nursery ground. Journal of the Marine Biological Association of the United Kingdom 53: 93-118.

MOORE, P.G. 1972: Particulate matter in the sublittoral zone of an exposed coast and its ecological significance with special reference to the fauna inhabiting kelp holdfasts. Journal of Experimental Marine Biology and Ecology 10: 59-80.

1973: The larger Crustacea associated with holdfasts of kelp (Laminaria hyperborea) in North-East Britain. Cahiers de Biologie Marine 14: 493-518.

MORGANS, J.F.C. 1956: Notes on the analysis of shallow-water soft substrata. Journal of Animal Ecology 25: 367-387.

MORTON, J.E. \& MILLER, M. 1968: "The New Zealand Seashore." Collins, London. 638pp.

MOUNTFORD, M.D. 1962: An index of similarity and its application to classificatory problems. In "Progress in Soil Science," MURPHY, P.W. (ed) . Butterworths, London: 43-50.

MUKAI, H. 1971: The phytal animals on the thalli of Sargassum serratifolium in the Sargassum region, with reference to their seasonal fluctuations. Marine Biology 8: 170-182.

NICHOLLS, A.G. 194 la: Littoral Copepoda from South Australia (1) Harpacticoida. Records of the South Australian Museum 6: 381-427.

1941b: A revision of the families Diosaccidae Sars, 1906 and Laophontidae T. Scott, 1905 (Copepoda, Harpacticoida). Records of the South Australian Museum 7: 65-110.

1944: Littoral Copepoda from the Red Sea. Annals and Magazine of Natural History 11: 487-503.

NORTON, T.A. 1971: An ecological study of the fauna inhabiting the sublittoral marine alga Saccorhiza polyschides (Lightf.) Batt. Hydrobiologia 37: 215- 231 .

NYHOLM, K-G. \& OLSSON, I. 1973: Seasonal fluctuations of the meiobenthos in an estuary on the Swedish west coast. Zoon 1: 69-76.

OHM, G. 1964: Die Besiedlung der Fucus - Zone der Kieler Bucht und der westlichen ostsee unter besenderer Berücksichtigung der Mikrofauna. Kieler Meeresforschungen 20: 30-64. 
OLSSON, B.H. 1955: Electrical effects of tidal streams in Cook Strait, New Zealand. Deep Sea Research 2: 204-212.

PALLARES, R.E. 1966: Sobre una nueve especie de Porcellidium (Copepoda, Harpacticoida). Physis (Bueños Aires) 26: 113-120.

1968: Copepodos marinos de la Ria Deseado (Santa Cruz, Argentina). Contribucion sistematico - ecologica. II. Physis (Buenos Aires) 27: 245-262.

1969: El genero Scutellidium en la Ria Deseado (Crustacea, Copepoda). Physis (Buenos Aires) 29: 51-72.

1970: Copepodos marinos de la Ria Deseado (Santa Cruz, Argentina). Contribucion sistematico - ecologica. III. Physis (Buenos Aires) 30: 255-282.

1973a: El genero Harpacticus en la Ria Deseado (Crustacea, Copepoda). Physis (Buenos Aires) 32:

275-288.

1973b: Sobre la presencia de Paramenophia platysoma en la Ria Deseado (Copepoda, Harpacticoida). Physis (Buenos Aires) 32: 289-293.

PALLARES, R.E. \& HALL, M.A. 1974a: Analisis bioestadistico ecologico de la fauna de copepodos asociados a los bosques de Macrocystis pyrifera. Physis (Buenos Aires) 33: $275-319$.

1974b: Analisis bioestadistico ecologico de la fauna de copepodos asociados a los bosques de Macrocystis pyrifera (Conclusion). Physis (Buenos Aires) 33: 409-432.

RITCHIE, L.D. 1970: Notes on sea surface temperatures at the Victoria University Marine Laboratory, Island Bay, Cook Strait. Bulletin of Natural Sciences Victoria University of Wellington Biological Society 1: 1-4.

ROBERTS, L.I.N. 1974: A preliminary analysis of the meiofauna of three sandy beaches in Wellington Harbour. Unpublished B.Sc.(Hons.) dissertation, Zoology Department, Victoria University of Wellington: 6lpp.

SALVAT, B. \& RENAUD-MORNANT, J. 1969: Etudes ecologique du macrobenthos et du méiobenthos d'un fond sableux du lagon de Mururoa (Tuamotu-Polynesie). Cahiers du Pacifique 13: 159-179.

SARS, G.O. 1905: Pacifische Plankton-Crustaceen. II. Brackwasser - Crustaceen von den Chatham-Inseln.

Zoologische Jahrbücher 21: 371-414.

1911: "An Account of the Crustacea of Norway. Vol. $\underline{5}$. Copepoda, Harpacticoida." Albert Cammermeyer's Forlag, Bergen: 449pp. 
SCHEIBEL, W. 1973: Quantitative-ökologische Untersuchungen am uferfernen Mesopsammon in der Kieler Bucht. Kieler Meeresforschungen 29: 58-68.

1976: Quantitative Untersuchungen am Meiobenthos eines Profils unterschiedlicher sedimente in der westlichen Ostsee. Helgoländer wissenschaftliche Meeresuntersuchungen 28: $31-42$.

SCHEIBEL, W. \& NOODT, W. 1975: Population densities and characteristics of meiobenthos in different substrates in the Kiel Bay. Merentutkimuslaitos Julkaisuja/ Havsforskningsinstitutets 239: 173-178.

SCHMIDT, P. 1968: Die quantitative Verteilung und Populationsdynamik des Mesopsammons am Gezeiten-Sandstrand der Nordsee-Insel sylt. I. Faktorengefüge und biologische Gliederung des Lebensraumes. Internationale Revue der gesamten Hydrobiologie und Hydrographie 53: 723-779.

1969: Die quantitative Verteilung und Populationsdynamik des Mesopsammons am Gezeiten-Sandstrand der Nordsee-Insel Sylt. II. Quantitative Verteilung und Populationsdynamik einzelner Arten. Internationale Revue der gesamten Hydrobiologie und Hydrographie 54: 95-174.

SCOTT, T. 1893: Report on the Entomostraca from the Gulf of Guinea collected by John Rattray, B.Sc. Transactions of the Linnean Society of London (Zool.) Ser.2 6: 1-161.

SEELYE, C.J. 1940: Variability of annual rainfall in New Zealand. N.z. Journal of Science and Technology 26: 18-21.

SEWELL, R.B.S. 1956: The continental drift theory and the distribution of the Copepoda. Proceedings of the Linnean Society of London 166: 149-177.

SORENSON, T. 1948: A method of establishing groups of equal amplitude in plant sociology based on similarity of species content and its application to analyses of the vegetation on Danish commons. K. Danske videnskabernes selskab. Skrifter 5: 1-34.

SOYER, J. 1970: Bionomie benthique du plateau continental de la Côte Catalane Française. III. Les peuplements de Copépodes Harpacticoides (Crustacea). Vie et Milieu 21: $337-511$.

STERRER, W. 1973: Plate tectonics as a mechanism for dispersal and speciation in interstitial sand fauna. Netherlands Journal of Sea Research 7: 200-222.

THIEL, H. 1966: Quantitative Untersuchungen über die Meiofauna des Tiefseebodens. Veröffentlichungen des Instituts fur Meeresforschung in Bremerhaven 2: 131-148.

1971: Häufigkeit und Verteilung der Meiofauna im Bereich des Island-Färöer-Rückens. Berichte der Deutschen Wissenschaftlichen Kommission fur Meeresforschungen 22: 99-128. 
1972: Meiofauna und Struktur der benthischen Lebensgemeinschaft des Iberischen Tiefseebeckens. "Meteor" Forschungsergebnisse (Ser. D) 12: 36-51.

THOMASSIN, B.A., VIVIER, M-H. \& VITIELLO, P. 1976: Distribution de la méiofaune et de la macrofaune des sables coralliens de la retenue d'eau épirécifale du Grand Récif de Tuléar (Madagascar). Journal of Experimental Marine Biology and Ecology 22: $31-53$.

TIETJEN, J.H. 1969: The ecology of shallow water meiofauna in two New England estuaries. Oecologia (Berl.) 2 : 251-291.

1971: Ecology and distribution of deep-sea meiobenthos off North Carolina. Deep-Sea Research 18: 941-957.

UHLIG, G., THIEL, H. \& GRAY, J.S. 1973: The quantitative separation of meiofauna: A comparison of methods. Helgoländer wissenschaftliche Meeresuntersuchungen 25: 173-195.

VERVOORT, W. 1964: Free living Copepoda from Ifaluk Atoll in the Caroline Islands. Bulletin of the United States National Museum 236: 1-431.

WARWICK, R.M. \& BUCHANAN, J.B. 1971: The meiofauna off the coast of Northumberland. II. Seasonal stability of the nematode population. Journal of the Marine Biological Association of the United Kingdom 51: 355-362.

WATTS, I.E.M. 1947: The relation of New Zealand weather and climate: an analysis of the westerlies. N.Z. Geographer 3: 115-129.

WIBORG, K.F. 1964: Marine copepods of Tristan da Cunha. Results of the Norwegian Scientific Expedition to Tristan da Cunha, 1937-38 (51): 1-44.

WIESER, W. 1951: Über die quantitative Bestimmung der algenbewohnenden Mikrofauna felsiger Meeresküsten. Oikos 3: 124-131.

1959: Zur Ökologie der Fauna mariner Algen mit besonderer Berucksichtigung des Mittelmeeres. Internationale Revue der gesamten Hydrobiologie und Hydrographie 44: 137-180.

WELLS, J.B.J. 1967: The littoral Copepoda (Crustacea) of Inhaca Island, Mozambique. Transactions of the Royal Society of Edinburgh 67: 189-358.

1968: New and rare Copepoda Harpacticoida from the Isles of Scilly. Journal of Natural History 2: 397-424.

1970: The marine flora and fauna of the Isles of Scilly Crustacea: Copepoda: Harpacticoida. Journal of Natural History 4: 255-268. 
WELLS, J.B.J. \& MCKENZIE, K.G. 1973: Report on a small collection of benthic copepods from marine and brackish waters of Aldabra, Indian Ocean. Crustaceana 25: 133-146.

WESTLAKE, D.F. 1971: Macrophytes. IBP Handbook No. 12. - "A Manual on Methods for Measuring Primary Production in Aquatic Environments." VOLLENWEIDER, R.A. (ed) Section 2.2: 25-32.

YEATMAN, H.C. 1962: The problem of dispersal of marine littoral copepods in the Atlantic Ocean, including some redescriptions of species. Crustaceana 4: 253-272. 
PAPER 2

ECOLOGICAL STUDIES ON MARINE ALGAL-DWELLING COPEPODA (Harpacticoida). 2. SEASONAL CHANGES IN POPULATION DENSITY; SPECIES OCCURRENCE AND ASSOCIATIONS.

pages: $74-130$ 


\section{ECOLOGICAL STUDIES ON MARINE ALGAL-DWELLING COPEPODA (HARPACTICOIDA). 2. SEASONAL CHANGES IN POPULATION DENSITY; SPECIES OCCURRENCE AND ASSOCIATIONS.}

\section{GEOFFREY R.F. HICKS}

Zoology Department, Victoria University of Wellington, Private Bag, Wellington, New Zealand.

\section{ABSTRACT}

A quantitative study was made on the species occurrence, density, seasonal periodicity and associations of the harpacticoids collected from six species of marine algae at Island Bay, Wellington, New Zealand. Seasonal changes for twenty-seven species are described over a period from April 1973 to March 1974. Total population densities from each algal assemblage were some of the highest yet recorded from marine algae; the midlittoral pool Corallina having up to 578 individuals $.10 \mathrm{~cm}^{-2}$. Such densities are equivalent to those recorded from level-bottom sandy sediments.

The pattern of population density for each assemblage was characterised by seasonal fluctuations in abundance of the dominant species on each alga; the timing of population maxima differing noticeably between species. Total population values were highest in the spring for Corallina and Ecklonia, in summer for Enteromorpha, Zonaria and Pterocladia and in autumn for Xiphophora. Fluctuations in abundance are largely attributable to the seasonal breeding activity of individual species which in most cases was unrelated to environmental temperature. Paralaophonte meinerti was the overall dominant species, constituting $14.5 \%$ of the total. Six indicator species 

$(1974 \mathrm{a}, \mathrm{b})$, little data exists on the seasonal status and associations of algal-dwelling harpacticoid populations.

Detailed accounts so far published show distinct cycles of population density with many species attaining maxima at different times, but in general they occur in greatest numbers during the summer months. Seawater temperature has been regarded as the primary controlling environmental factor in these studies, apparently influencing the population density directly via its action on the reproductive activity of the selected species. Maximum abundance may vary from year to year and the population may be dominated by different species at different times in one year.

A study was undertaken to determine population structure, density and seasonal periodicity of algal-dwelling harpacticoids and to compare them with their sediment-dwelling counterparts. This account investigates the species occurrence, seasonal changes in abundance, species dominance and affinities of the harpacticoids associated with six species of marine algae at. Island Bay, Wellington, New Zealand. It is stressed that the present results are from only one site and one year, but serves to illustrate the order of magnitude to be expected in population densities.

The algal-dwelling harpacticoid fauna and its zoogeography, habitat interrelationships and the contribution of these copepods to the total phytal meiobenthos have been described in a separate paper (Hicks in press a). The influence of reproductive activity of selected species on population structure and density is discussed elsewhere (Hicks in press b). 
METHODS

A full account of the study area, variation in environmental parameters and the sampling techniques has been given in a previous paper (Hicks in press a). Seaweed samples were collected within the last week of each month (April 1973-March 1974). Duplicate, and in some cases triplicate samples were taken resulting in a total of 154 samples collected. Sublittoral samples were collected by SCUBA - diving with a portable sampler cutter measuring $10 \mathrm{~cm} \times 10 \mathrm{~cm}$. All copepod densities are therefore expressed as numbers $.10 \mathrm{~cm}^{-2}$ of algal-covered rock surface. Copepods were removed from the algae after narcotization with isotonic $\mathrm{MgCl}$, followed by fixation in $10 \%$ formalin. Copepods from sublittoral algae were hand sorted while those from Corallina officinalis in intertidal pools were collected by the swirling-decantation method (see Uhlig et al. 1973). Final hand sorting, identification and counting was done in graduated petri dishes beneath a stereoscopic microscope. The extracted samples were stored in a $2: 1$ mixture of $5 \%$ formalin and $50 \%$ mono-ethylene glycol.

The mean, variance and standard deviation were each calculated from pooled șample data to indicate the degree of sampling error for quantitative values. In the tested data a S.D. of about 5\% was attained and is considered acceptable in detecting successive changes in population levels. The collection efficiency was estimated at over $90 \%$ after periodic checks on the procedure were conducted (Hicks in press a). Copepods on seaweeds were enumerated in relation to $10 \mathrm{~cm}^{2}$ of rock surface, as the differences in absolute surface area of the algae studied varied noticeably (see Hicks in press a). Population densities, although comparable within each seaweed 
from season to season, are comparable between seaweeds only when it is remembered that each alga represents a distinctly different substrate. Thus the differences in population density of animals living on one alga is not directly comparable to the others, but month to month changes within each algal assemblage are considered significant.

In studying the fluctuations in population density and species composition from month to month only the numerically commonest species, or those readily comparable with previously published work, have been considered from each alga. The monthly mean fluctuations in population density and percentage composition are given in Figs. $1-8$ and Tables $1-6$ respectively. In no month was there a statistically significant difference in population density between the two duplicate sets of samples, and the values from both have been combined to give a monthly mean. Temporal changes in the total population of each species is based on the numerical combination of adults and copepodites, nauplii being omitted.

A summary of species occurrence on each seaweed and actual numbers collected from all samples over twelve months is given in Table 7. The taxonomic status of the species included here is in many cases tentative, but is discussed more fully by Hicks (in press a).

In all algal-dwelling copepod assemblages distinct seasonal periodicity in population density was observed. Such variability results mainly from the fluctuations of the dominant species while fluctuations in the rarer species had little effect on the density variability within each algal assemblage. The contribution to the seasonal pattern of total copepods by most of the more important population constituents on each alga is analysed separately for each assemblage. 


\section{RESULTS}

SEASONAL DENSITY FLUCTUATIONS

\section{$\frac{\text { Enteromorpha }}{\text { assemblage }} \frac{\text { intestinalis }}{\text { (Fig. 1). }}$}

Total population density of the copepods associated with Enteromorpha showed a marked increase in numbers during the summer, culminating in a maximum of $366.10 \mathrm{~cm}^{-2}$ in February. This summer maximum was due to the combined population levels of Tisbe holothuriae and Robertsonia propingua, with Mesochra flava contributing mainly to the fluctuating density throughout the rest of the year. By March the total population had declined to below the annual mean level of $75.10 \mathrm{~cm}^{-2}$. Unfortunately November samples were lost.

The species from Enteromorpha pools are largely controlled by physico-chemical parameters. Tolerances to extremes of temperature and salinity in $\mathrm{R}$. propinqua and $\underline{T}$. holothuriae have been recognized earlier (Bayly 1970, Fava \& Volkmann 1975). The isolated supralittoral environment is influenced by wave splash which periodically introduces species from the nearby Corallina assemblage. The month of september was noted for its high incidence of rough weather (Hicks in press a, Fig. 4) and complete tidal inundation of the supralittoral pools was observed two days before sampling. Amonardia perturbata, Ectinosoma australe, Bulbamphiascus imus, Ameira minuta, Orthopsyllus linearis and Paralaophonte meinerti were subsequently collected and these had a noticeable effect on percentage composition of the assemblage (Table 1). The near absence of these species the following month (0.4\%) suggests that their longevity in this environment was limited, due to either the violent short term fluctuations in the physico-chemical 
regime or to the competitive interactions of the better adapted permanent residents.

Tisbe holothuriae Humes (Fig. 1).

T. holothuriae was the dominant species found on Enteromorpha (53.3\%) and was the most obvious constituent throughout the year (Table 1). From the minimum density of $2.10 \mathrm{~cm}^{-2}$ in september the population increased sharply to reach a maximum of $153.10 \mathrm{~cm}^{-2}$ in February. Numbers declined after this peak to remain below $25.10 \mathrm{~cm}^{-2}$ for the remainder of the year. The mean annual density, based on eleven monthly samples was $39.8 \cdot 10 \mathrm{~cm}^{-2}$.

Robertsonia propinqua (T. Scott) (Fig. 1).

The occurrence of $\underline{R}$. propinqua proved to be strictly seasonal and was not observed in the samples until October. Large numbers were found in summer, culminating in the February peak of $187.10 \mathrm{~cm}^{-2}$. This was followed by a pronounced decline in the population in March leading to the disappearance of the species by April. It was only in February that $\underline{R}$. propinqua had a proportional contribution to the population of over $50 \%$ (Table 1). The contribution of this species to the total annual population was therefore low (Table 1). Mean annual population density was $25.9 \cdot 10 \mathrm{~cm}^{-2}$.

Mesochra flava Lang (Fig. 1).

Densities fluctuated between 2 and $18.10 \mathrm{~cm}^{-2}$ over the study period. Numbers increased in late winter-early spring $\left(11.10 \mathrm{~cm}^{-2}\right)$ when the species was at its greatest proportion (Table 1). This was followed in January-February by a sustained $18.10 \mathrm{~cm}^{-2}$ over both months. Average number over the year was $8.10 \mathrm{~cm}^{-2}$. 
81.

FIG. 1 - Seasonal variation in population density of the harpacticoids associated with the alga Enteromorpha intestinalis. Monthly values represent the mean of duplicate samples taken from April 1973-March 1974. Broken lines indicate no data. 


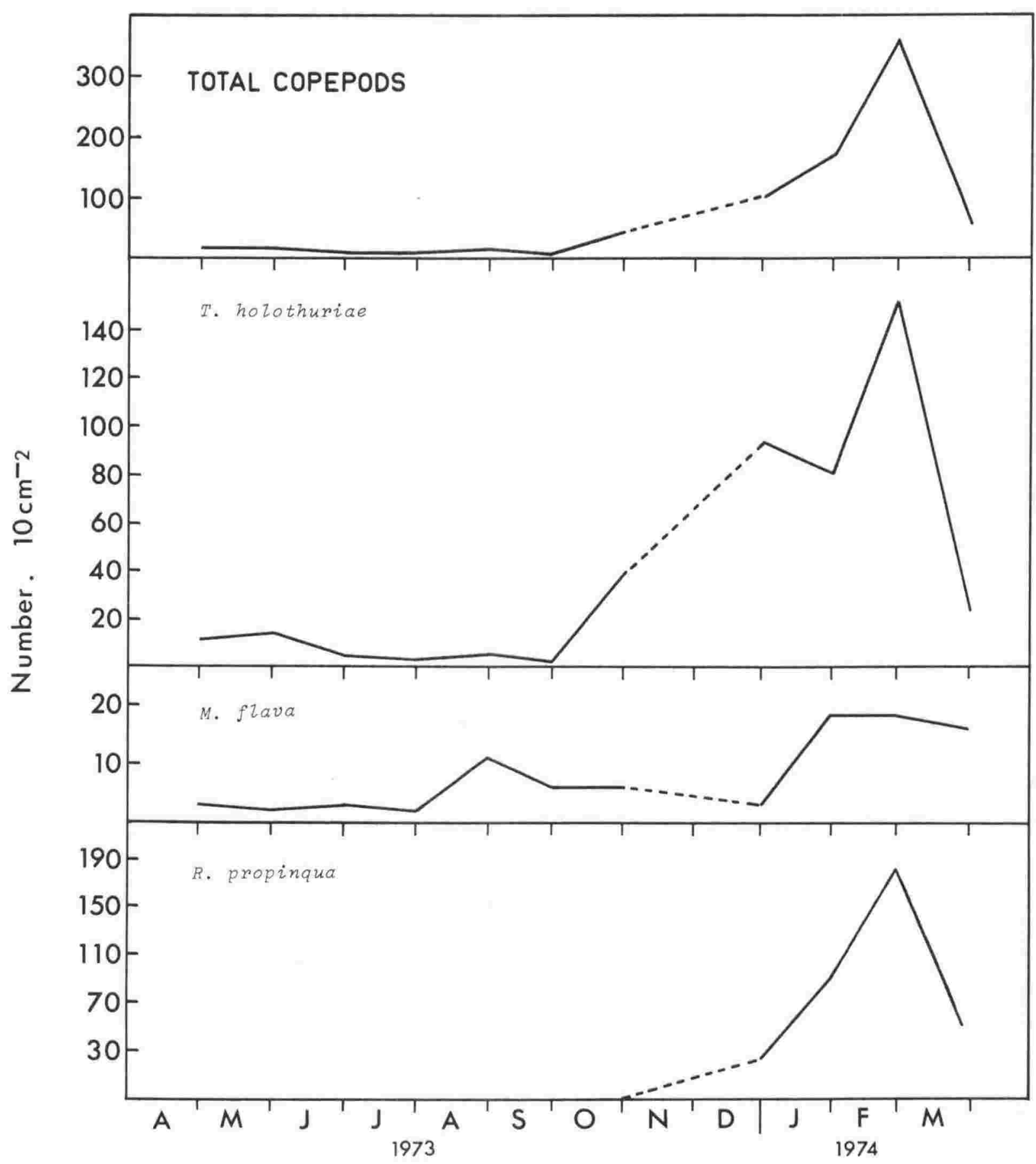




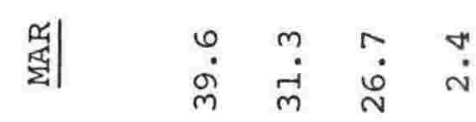

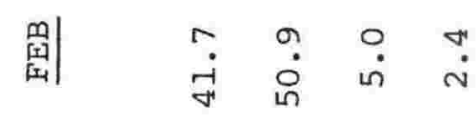

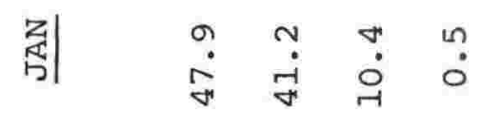

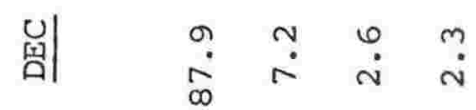

\begin{tabular}{lllll}
\hline & & & & \\
$z$ & 1 & 1 & 1
\end{tabular}

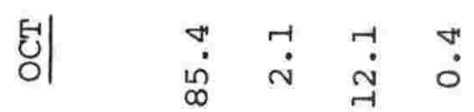

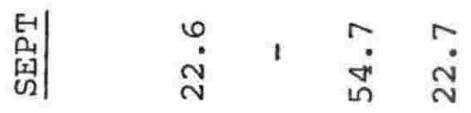

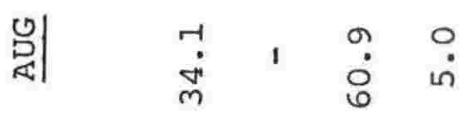

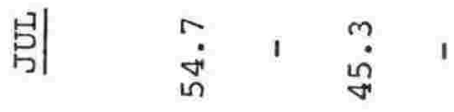

$\begin{array}{lllll}3 & 0 & & \infty & \sim \\ h^{\prime} & 0 & 1 & \infty & -\dot{m}\end{array}$

$\begin{array}{lllll}3 & 0 & & 0 & \\ & 0 & 1 & \dot{n} & 1\end{array}$

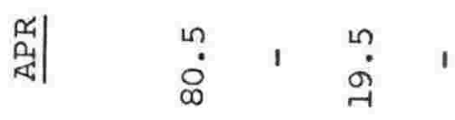

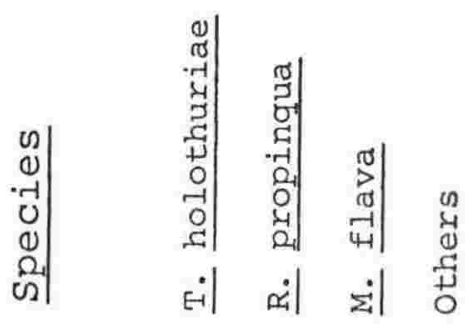




$$
\text { Corallina officinalis }
$$

As can be seen from Fig. 2 there was essentially two peaks of abundance of the total harpacticoid fauna associated with Corallina. The first occurred in early spring (September) and was the largest, reaching a total cumulative population density of $578.10 \mathrm{~cm}^{-2}$. After a decline during October and November the population increased to a secondary maximum in January of $457.10 \mathrm{~cm}^{-2}$. Mean annual population density for the Corallina assemblage was $294.2 \cdot 10 \mathrm{~cm}^{-2}$.

Species composition and density within the Corallina assemblage appears related to both the high level of deposited sediments and to surface area of the alga. Expansion of niche number and consequent increase in available biotic space distinguishes this assemblage from all others. In September, tidal invasion of supralittoral rockpools resulted in the translocation of large numbers of Tisbe holothuriae into the coralline zone where the species there contributed nearly $10 \%$ of the faunal composition for this month (Table 2).

Ectinosoma australe Brady (Fig. 2)

No E. australe were collected in May but numbers increased from July reaching a small peak in August. In this species increase in numbers during the summer was very marked. Density rose to the late summer maximum of $59.10 \mathrm{~cm}^{-2}$ in February. The mean annual population density was $17.4 .10 \mathrm{~cm}^{-2}$ and represented $6.1 \%$ of the copepods in the Corallina assemblage (Table 8). 
84.

FIG. 2 - Seasonal variation in population density of the harpacticoids associated with the alga Corallina officinalis. Monthly values represent the mean of two and sometimes three replicate samples taken from April 1973-March 1974 . 


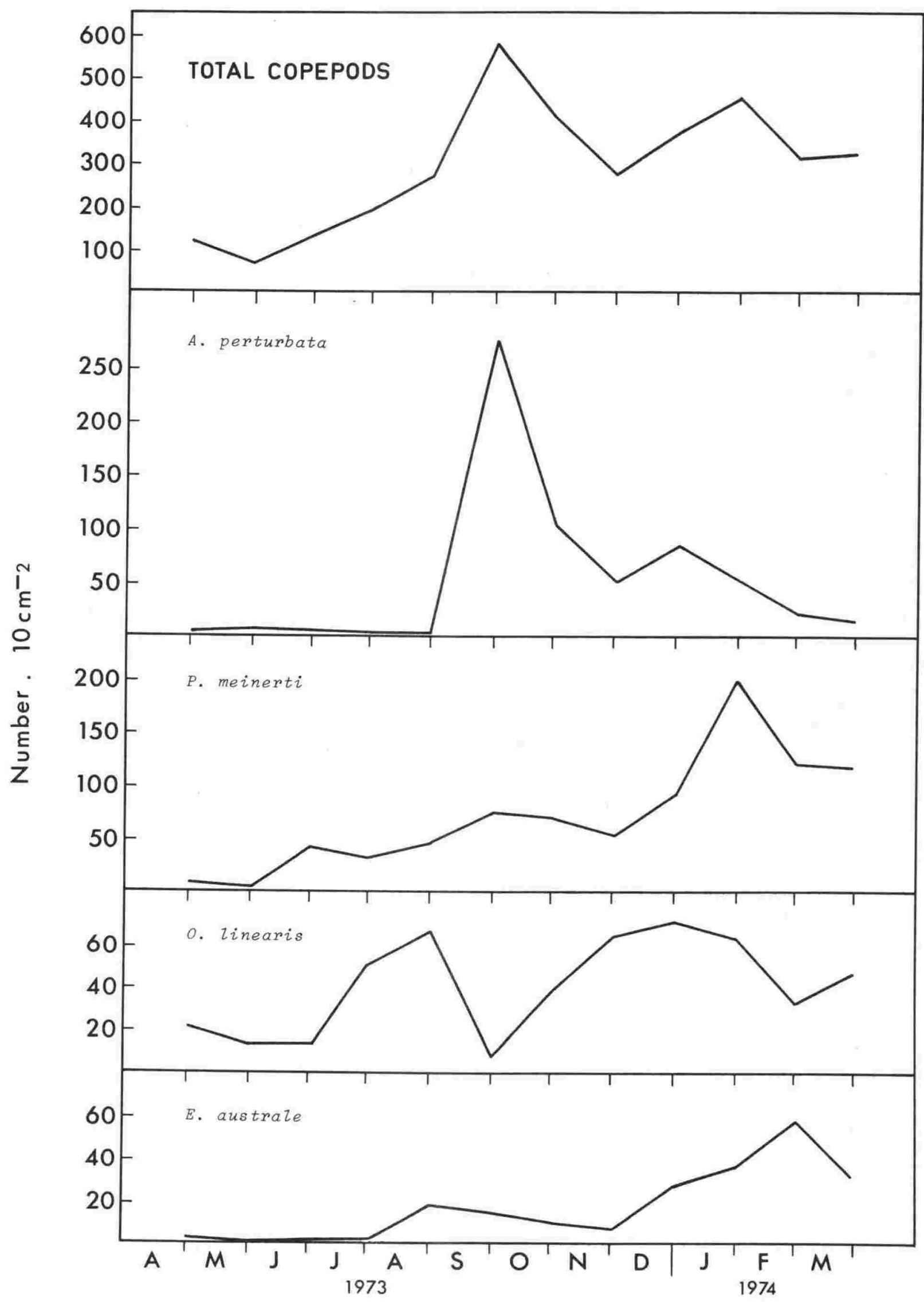


85.

FIG. 3 - Seasonal variation in population density of the harpacticoids associated with the alga Corallina officinalis. Monthly values represent the mean of two and sometimes three replicate samples taken from April 1973-March 1974. 


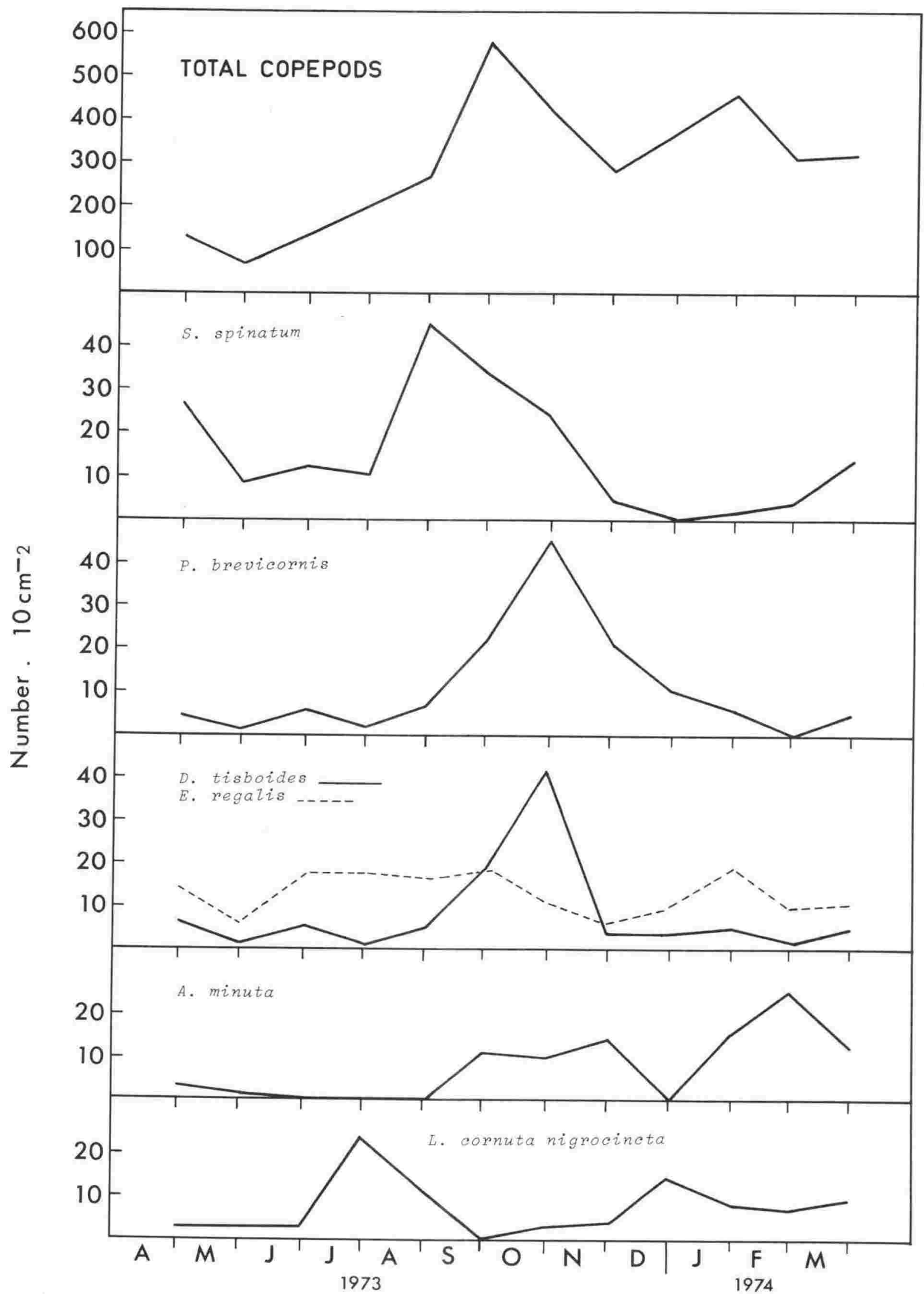


86.

FIG. 4 - Seasonal variation in population density of the harpacticoids associated with the alga Corallina officinalis. Monthly values represent the mean of two and sometimes three replicate samples taken from April 1973-March 1974. 


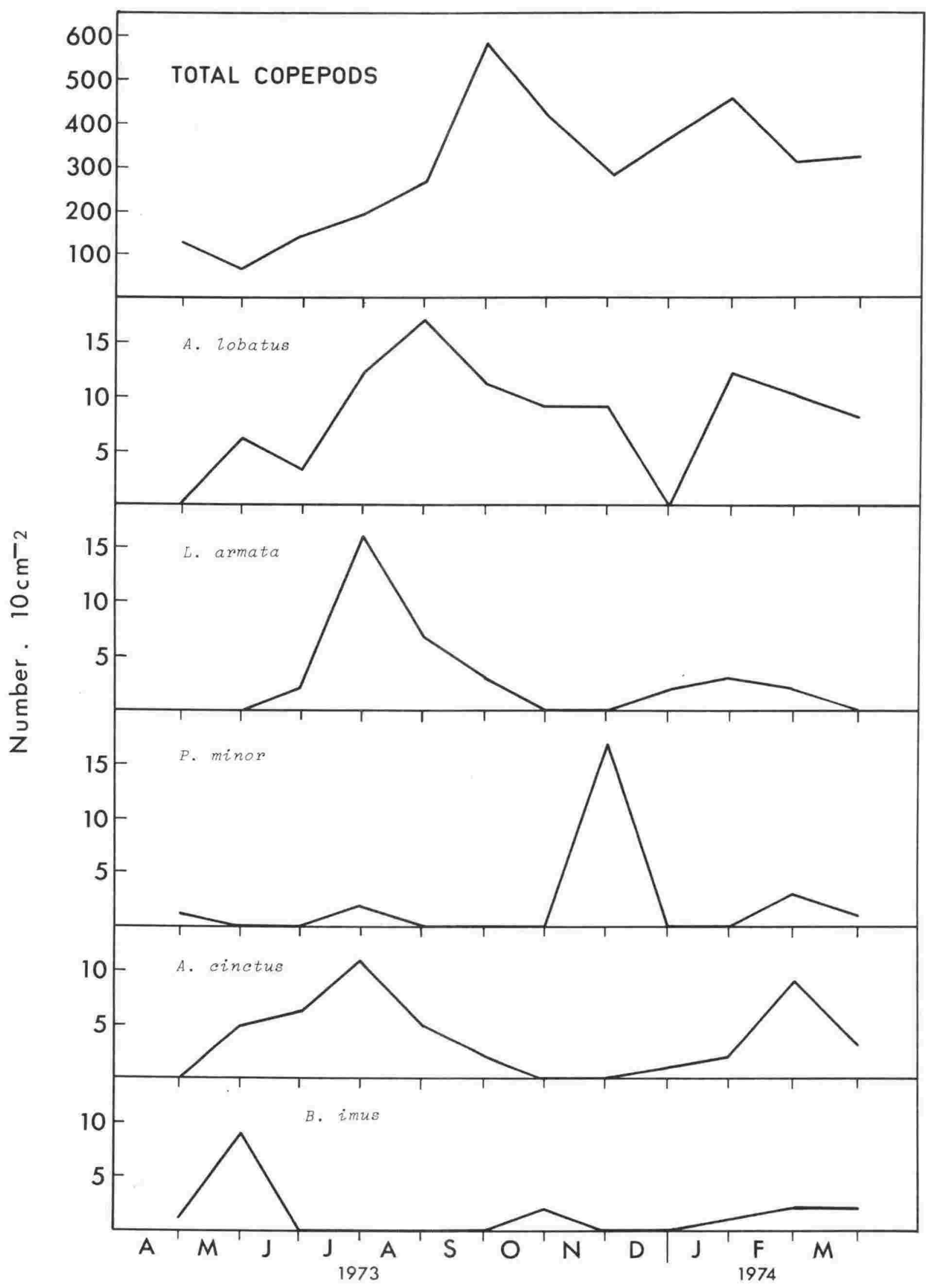




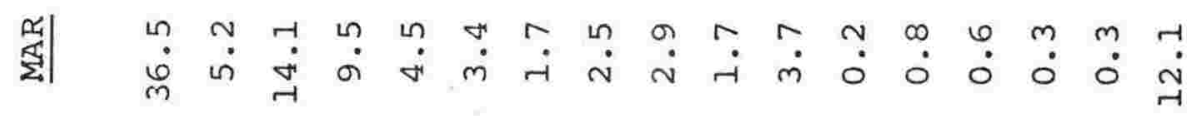

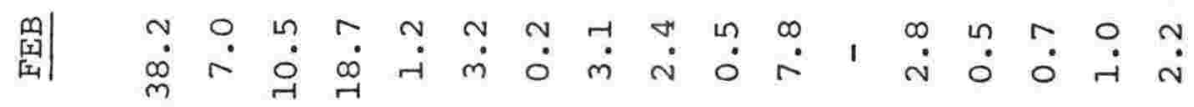

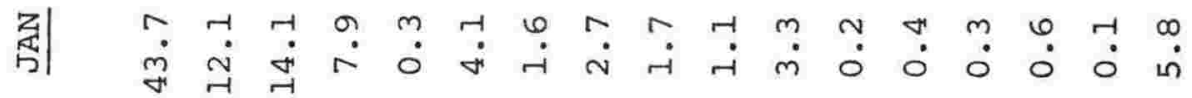

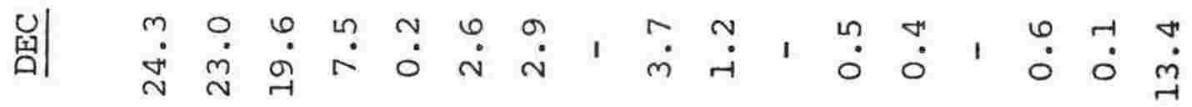

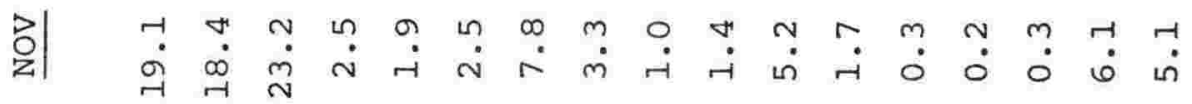

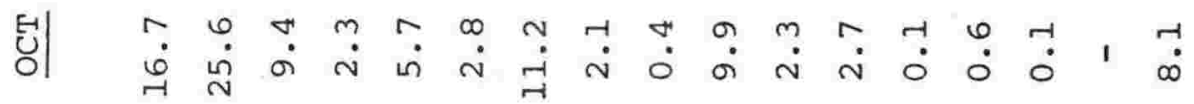

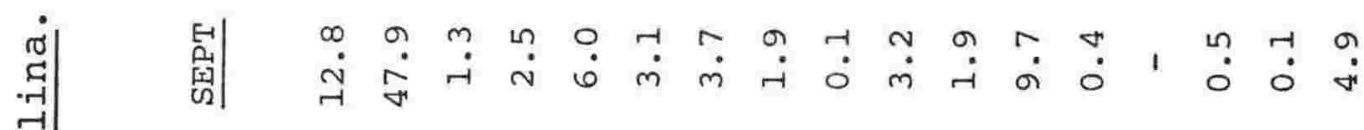

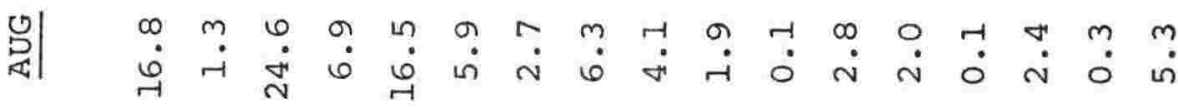

도

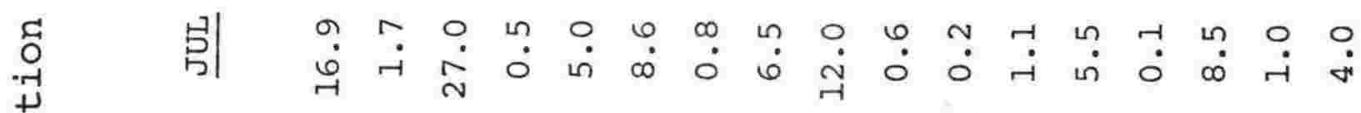

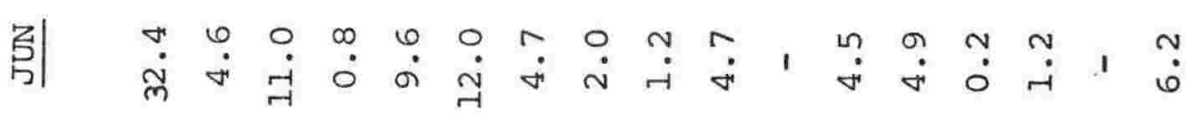

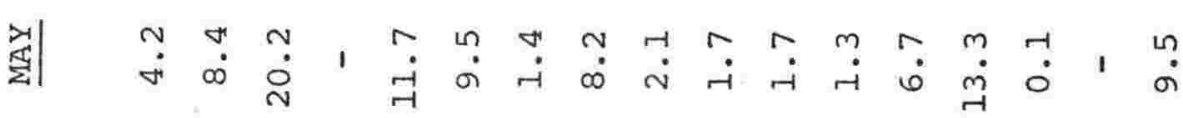

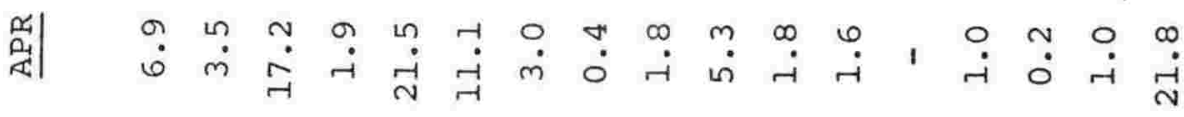

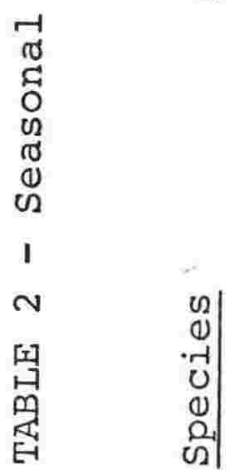

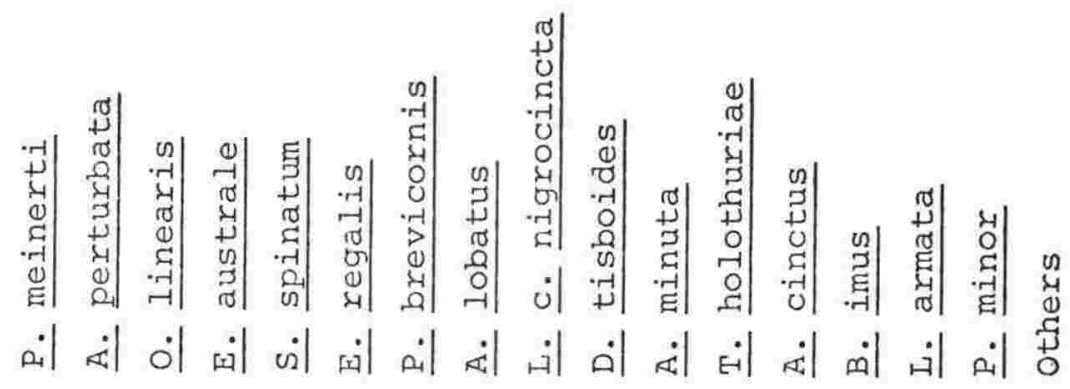


Scutellidium spinatum Hicks (Fig. 3).

This species occurred in low numbers in December and maximum densities occurred in April $\left(27.10 \mathrm{~cm}^{-2}\right)$ and August $\left(45.10 \mathrm{~cm}^{-2}\right)$. The autumn peak represents $21.5 \%$ (Table 2) of the copepod population on Corallina and occurred when the abundance of many other species had declined. The mean annual population density was $15.4 .10 \mathrm{~cm}^{-2}$ representing $5.5 \%$ of the species associated with Corallina (Table 8).

Eupelte regalis Hicks (Fig. 3).

In this species densities remained quite stable between $7.10 \mathrm{~cm}^{-2}$ in May and November to $19.10 \mathrm{~cm}^{-2}$ in January. E. regalis was proportionally at its greatest in autumn and early winter (April-July, Table 2) and accounted for $4.5 \%$ of the copepods occurring on Corallina (Table 8). The mean annual population density was $13.1 \cdot 10 \mathrm{~cm}^{-2}$.

Dactylopodia tisboides (Claus) (Fig. 3).

There was a distinct spring maximum population density in this species which reached $42.10 \mathrm{~cm}^{-2}$. Numbers declined sharply during November, to a low level which never rose above $7.10 \mathrm{~cm}^{-2}$ throughout the rest of the year. D. tisboides never exceeded $10 \%$ of the total fauna (Table 2), and comprised a mean annual $3 \%$ of the fauna on Corallina. Average yearly population density was $8 \cdot 3 \cdot 10 \mathrm{~cm}^{-2}$.

Paradactylopodia brevicornis (Claus) (Fig. 3).

Seasonal changes in population density resembled $\underline{\mathrm{D}}$. tisboides with a single maximum in october $\left(47.10 \mathrm{~cm}^{-2}\right)$. The population never fell below $22.10 \mathrm{~cm}^{-2}$ during the spring but throughout the rest of the year the density was always less than 
$11.10 \mathrm{~cm}^{-2}$. P. brevicornis represented only $0.2 \%$ in February but during the spring maximum accounted for $11.2 \%$ (Table 2). Average annual population density was $11.2 .10 \mathrm{~cm}^{-2}$.

Amphiascus lobatus Hicks (Fig. 4).

This species had a winter maximum of $17.10 \mathrm{~cm}^{-2}$. It was absent in December and represented a low proportion of the fauna in April. Mean annual population density for $\underline{A}$. lobatus was $8.1 \cdot 10 \mathrm{~cm}^{-2}$.

Amphiascopsis cinctus (Claus) (Fig. 4).

Abundance of this species attained two peaks with a maximum of $11.10 \mathrm{~cm}^{-2}$ in July, followed by another peak in February $\left(9.10 \mathrm{~cm}^{-2}\right)$. No A. cinctus were found in April and during late spring the species fell to its lowest proportion in the population (Table 2). The average density of the population throughout the year was $3,7 \cdot 10 \mathrm{~cm}^{-2}$.

Amonardia perturbata Lang (Fig. 2).

An early spring maximum in the total population density of all harpacticoids occurring on Corallina (Fig. 2) is largely due to the influence of $\underline{A}$. perturbata. This was the subdominant species on Corallina accounting for $18.7 \%$ of the total fauna (Table 8). From April to August the density was always below $6.10 \mathrm{~cm}^{-2}$. Numbers increased from $4.10 \mathrm{~cm}^{-2}$ in August to the seasonal maximum of $277.10 \mathrm{~cm}^{-2}$ in september. Abundance periodicity is related to the breeding pattern of the species (see Hicks in press b). This was the highest recorded density of any species during the entire study and represented $47.9 \%$ of all species collected in september (Table 2). During October and November the population underwent a precipitous decline but in 
90.

December another peak $\left(85.10 \mathrm{~cm}^{-2}\right)$ was evident. The mean annual population density was $53 \cdot 1.10 \mathrm{~cm}^{-2}$.

Bulbamphiascus imus (Brady) (Fig. 4).

B. imus is a minor constituent of the fauna but has been analysed to enable comparison with Dinet (1972). Annual mean population densities were the lowest of those species analysed $\left(1.4 .10 \mathrm{~cm}^{-2}\right)$ with a maximum of $9.10 \mathrm{~cm}^{-2}$ occurring in May, followed by a smaller increase in October. Since overall density is low, successive changes in population density may be insignificant. However, the maxima observed here correlate exactly with those of Dinet (1972). He found similar maxima in the late boreal autumn (November) and mid-spring (April) but in his study B. imus was the most unbiquitous and abundant species recorded.

Ameira minuta Boeck (Fig. 3).

Maximum density occurred in February $\left(25.10 \mathrm{~cm}^{-2}\right)$, followed by a decline during autumn until June when no specimens were collected. A. minuta was absent again in December. During the spring the density averaged $11.7 .10 \mathrm{~cm}^{-2}$ and the mean annual abundance amounted to $7.5 .10 \mathrm{~cm}^{-2}$.

\section{Phyllopodopsyllus minor (Thompson \& A. Scott) (Fig. 4).}

This species did not occur in the samples in May, June and October, and for most of the year represented a low proportion of the total population ( $0.8 \%$, Table 7). Maximum densities occurred in November $\left(17.10 \mathrm{~cm}^{-2}\right)$, but throughout the rest of the year the density only averaged about $1.8 .10 \mathrm{~cm}^{-2}$. Average yearly abundance was $2.10 \mathrm{~cm}^{-2}$. 
Orthopsyllus linearis (Claus) (Fig. 2).

Maximum densities were recorded in August $\left(68.10 \mathrm{~cm}^{-2}\right)$ and December $\left(72.10 \mathrm{~cm}^{-2}\right)$ and formed the highest proportion of the copepod population in late winter. 0 . linearis also had the highest percentage composition in November. This species, like Amonardia perturbata, may be considered a subdominant member of the Corallina assemblage and is a characteristic species of that habitat (Table 8). Mean annual population densities rank third behind Paralaophonte meinerti and $\underline{A}$. perturbata with $41.3 .10 \mathrm{~cm}^{-2}$. O. Iinearis reported by Coull (1970) from the coarse level-bottom sediments of Baileys Bay, Bermuda, exhibits a similar seasonal pattern of population density with maxima in the early boreal summer and late winter. Maximum densities in Bermuda, however, are about $35 \%$ lower than those recorded here.

Laophonte cornuta Philippi var. nigrocincta Nicholls (Fig. 3). This species similarly has winter and summer peaks of abundance. Maximum densities occurred in July $\left(23.10 \mathrm{~cm}^{-2}\right)$ and December $\left(14.10 \mathrm{~cm}^{-2}\right)$, but on average the population fluctuated between $2-11.10 \mathrm{~cm}^{-2}$ for the remainder of the year. The average density of the population throughout the year was $6.9 .10 \mathrm{~cm}^{-2}$.

Paralaophonte meinerti (Brady) (Fig. 2).

This was the dominant species in the Corallina assemblage, comprising $25.2 \%$ of the total harpacticoids (Table 8). Densities increased progressively from the minimum in May of $3.10 \mathrm{~cm}^{-2}$ to the mid-summer maximum of $200.10 \mathrm{~cm}^{-2}$. Numbers remained above $30.10 \mathrm{~cm}^{-2}$ for all months except April and May. It was by far the most abundant species over the summer, early autumn and also June. A mean percentage composition from December to March put $\underline{\mathrm{P}}$. meinerti at $35.7 \%$ of the total population over this period. 
P. meinerti achieved the highest mean annual population density of the entire study with $71.4 .10 \mathrm{~cm}^{-2}$.

Lourinia armata (Claus) (Fig. 4).

L. armata reached its maximum density in July $\left(16.10 \mathrm{~cm}^{-2}\right)$ but showed a further rise over the summer months. Overall population density was low $\left(2.9 .10 \mathrm{~cm}^{-2}\right)$ and of the species analysed, with the exception of Bulbamphiascus imus and Phyllopodopsyllus minor, had the lowest total annual contribution to the faunal density on Corallina.

\section{$\frac{\text { Zonaria }}{\text { assemblage (Fig. 5) }}$}

Two peaks in copepod population density were found on Zonaria; one in late summer and the other in late autumn (Fig. 5). The latter increase resulted in a density of $41.10 \mathrm{~cm}^{-2}$ in May after which the numbers declined to a mid-winter low of $11.10 \mathrm{~cm}^{-2}$. A rise in density occurred between August and February resulting in the seasonal maximum of $86.10 \mathrm{~cm}^{-2}$. Mean annual abundance in the Zonaria assemblage was $36.9 .10 \mathrm{~cm}^{-2}$.

While the composition of Enteromorpha and Corallina populations seem to be influenced primarily by physico-chemical features, the sublittoral algae appear to be controlled more by biological factors. The state of the algal surface, viz. available surface, biochemical and trophic condition, apparently dictate species occurrence and density.

\section{Zausopsis mirabilis Lang (Fig. 5).}

Densities fluctuated between 1 and $6.10 \mathrm{~cm}^{-2}$ during much of the study period. Maximum density occurred in October with $11.10 \mathrm{~cm}^{-2}$ followed by a further slight increase $\left(7.10 \mathrm{~cm}^{-2}\right)$ in 
FIG. 5 - Seasonal variation in population density of harpacticoids associated with the alga Zonaria turneriana. Monthly values represent the mean of two and sometimes three replicate samples taken from April 1973-March 1974. 


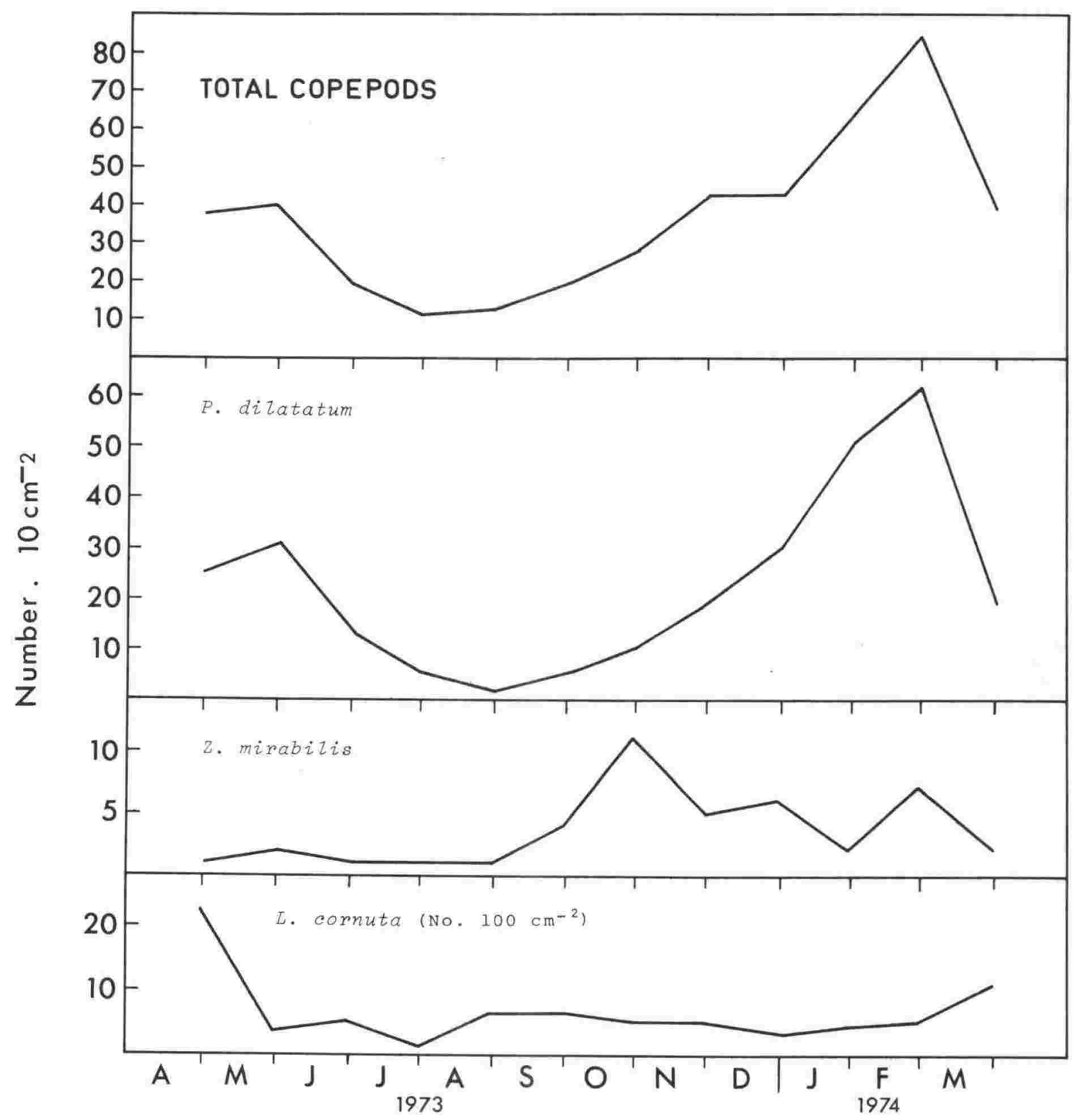




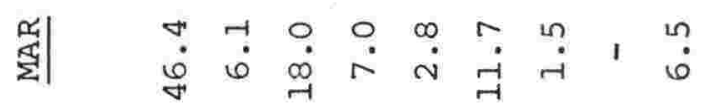

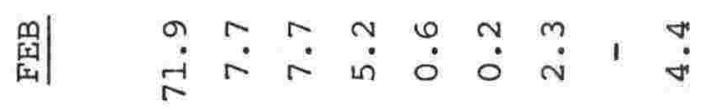

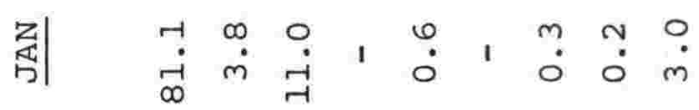

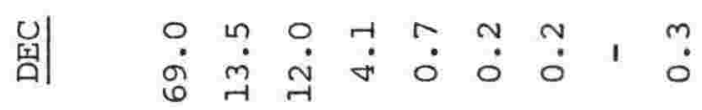

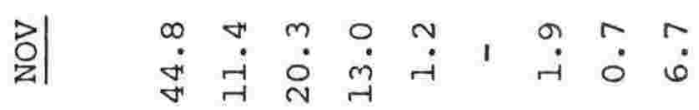

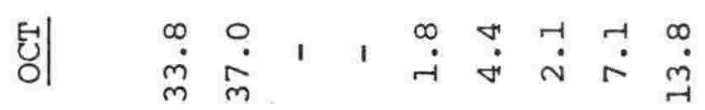

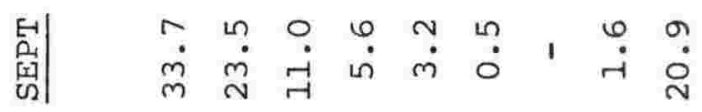

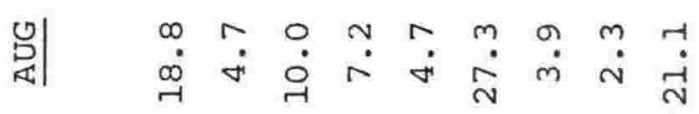

¿

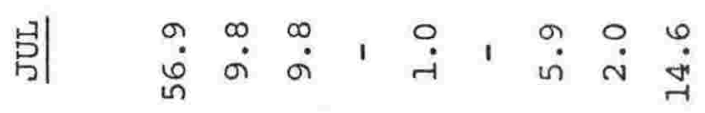

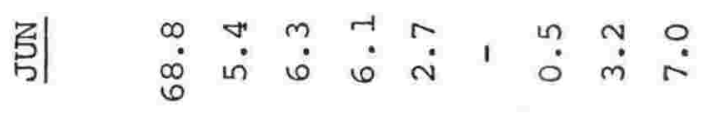

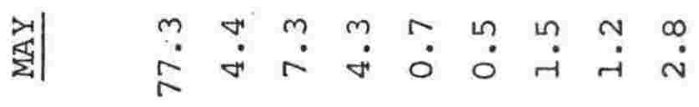

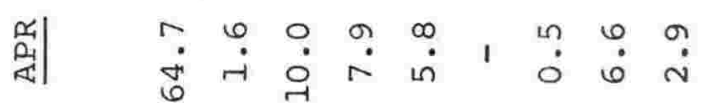

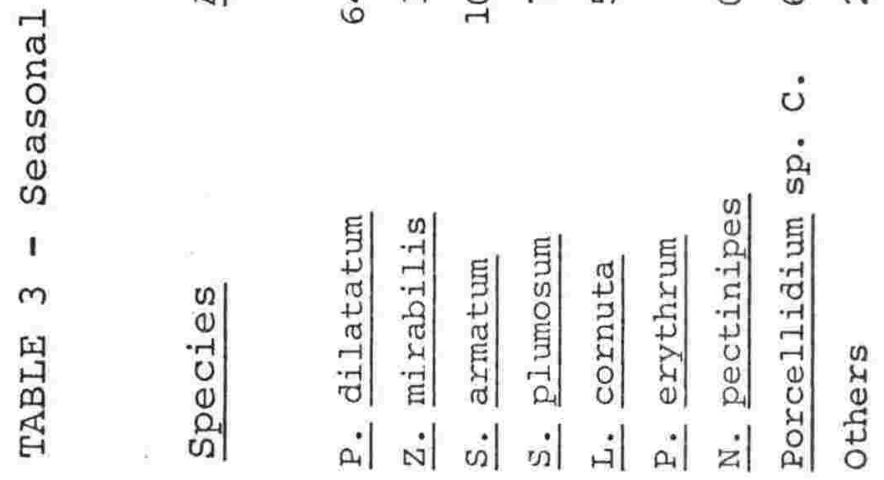


February. It was the most abundant species on Zonaria in October (Table 3). Annual density amounted to only $10.8 \%$ of the total fauna (Table 8), and the mean annual population density of Z. mirabilis was $3.4 .10 \mathrm{~cm}^{-2}$.

Porcellidium dilatatum Hicks (Fig. 5).

This was the dominant species on Zonaria and represented the highest number of specimens collected relative to the total fauna of all algae studied (Table 8). Seasonal fluctuations in abundance of $\underline{\mathrm{P}}$. dilatatum characterized the pattern of population density of the entire Zonaria assemblage (Fig. 5). Maximum numbers occurred in February with $62.10 \mathrm{~cm}^{-2}$, which was followed by a decline during March. In May the weaker rise was only half that of the summer peak and resulted in a density of $31.10 \mathrm{~cm}^{-2}$. October was the only month this species failed to dominate the population (Table 3). Mean annual population density was $22.8 .10 \mathrm{~cm}^{-2}$.

\section{Laophonte cornuta Philippi (Fig. 5).}

Numbers of this species throughout the year were low and consequently density figures are expressed in terms of number. $100 \mathrm{~cm}^{-2}$. The annual maximum was in autumn $\left(22.100 \mathrm{~cm}^{-2}\right)$ and throughout the rest of the year the population fluctuated between 1 and $6.100 \mathrm{~cm}^{-2}$; the majority of the changes in numbers between successive sampling dates were not significant. Mean annual population density was $6.3 .100 \mathrm{~cm}^{-2}$.

\section{$\frac{\text { Xiphophora }}{\text { assemblage (Fig. 6) }}$}

Maximum population densities occurred in mid-autumn $\left(39.10 \mathrm{~cm}^{-2}\right)$ and late spring $\left(38.10 \mathrm{~cm}^{-2}\right)$. Total mean population density for the Xiphophora association was low during the year 
with only $13.4 .10 \mathrm{~cm}^{-2}$ recorded. The fauna, like that on Ecklonia, is comprised mainly of 'allochthonous' (see Perkins 1974:235-6) eurytopic elements which occur periodically and in large numbers on other algae.

Scutellidium armatum (Wiborg) (Fig. 6).

This species is absent from Xiphophora in August, september and December, but peaks in population density were recognized in November, February and April. There was thus little detectable seasonal periodicity in abundance and the mean annual population density only amounted to $3.0 .10 \mathrm{~cm}^{-2}$. However, S. armatum dominated the population in May-July and February comprising $21.7 \%$ of the annual total individuals occurring on Xiphophora (Table 8). S. armatum is a eurytopic species, occurring as an important component also on Ecklonia, Pterocladia, and Zonaria (Table 8). An occurrence in such quantities on all these algae indicates its low degree of specific habitat selection (see Hicks in press c). However, analysis of the densities of populations found on algae other than Xiphophora (primarily Pterocladia) indicated the same seasonality with spring and late summer-autumn maxima.

Porcellidium erythrum Hicks (Fig. 6).

Population density was extremely variable in P. erythrum with the seasonal maximum occurring in April $\left(18.10 \mathrm{~cm}^{-2}\right)$, although it was the dominant species on Xiphophora. It is unknown whether such an irregular occurrence is the result of a sampling problem or represents some form of specific seasonal behaviour (e.g. migration). From May until the start of the autumnal increase numbers fluctuated between 1 and $7.10 \mathrm{~cm}^{-2}$. The species 
FIG. 6 - Seasonal variation in population density of the harpacticoids associated with the alga Xiphophora chondrophylla. Monthly values represent the mean of duplicate samples taken from April 1973-March 1974. 


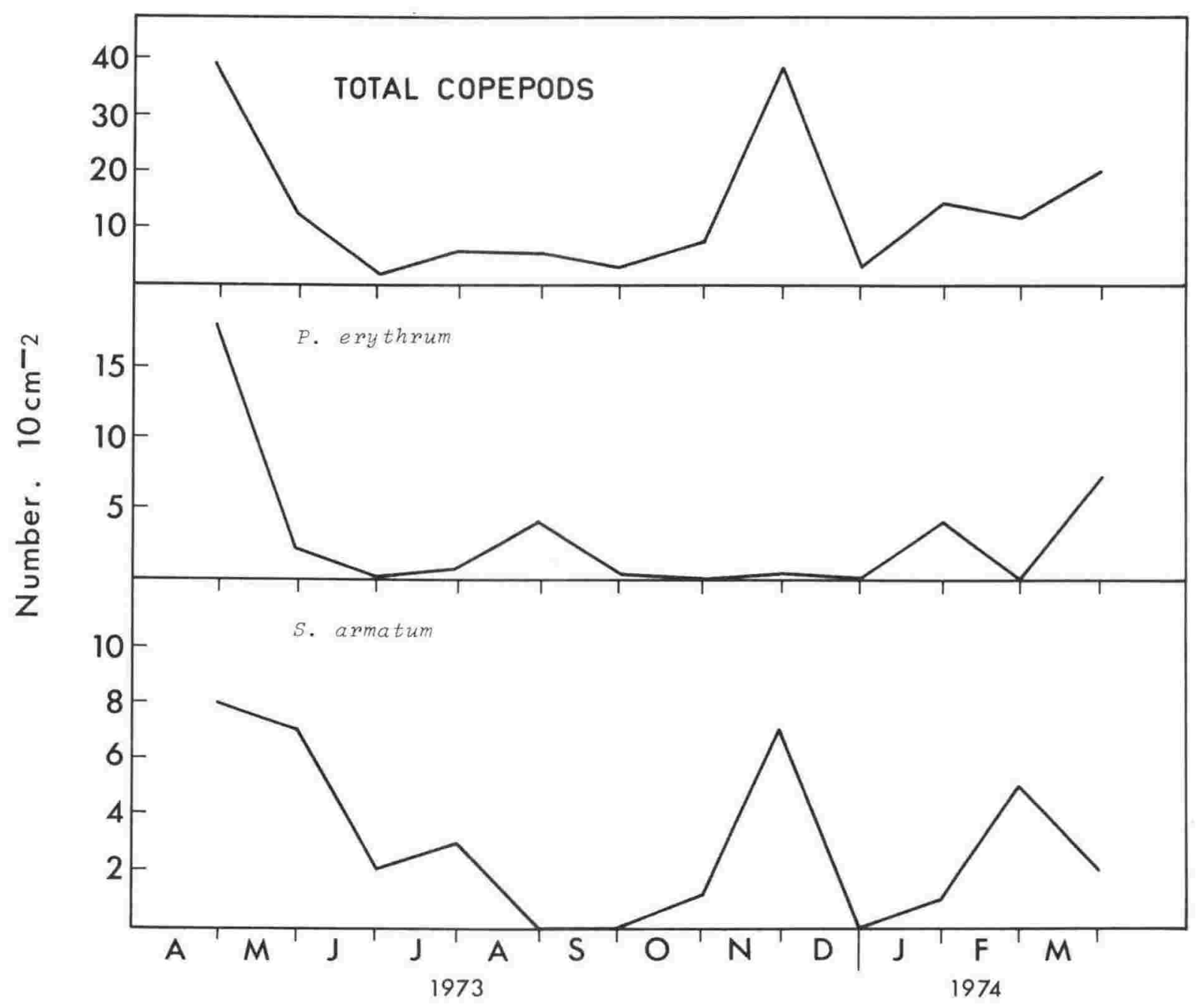




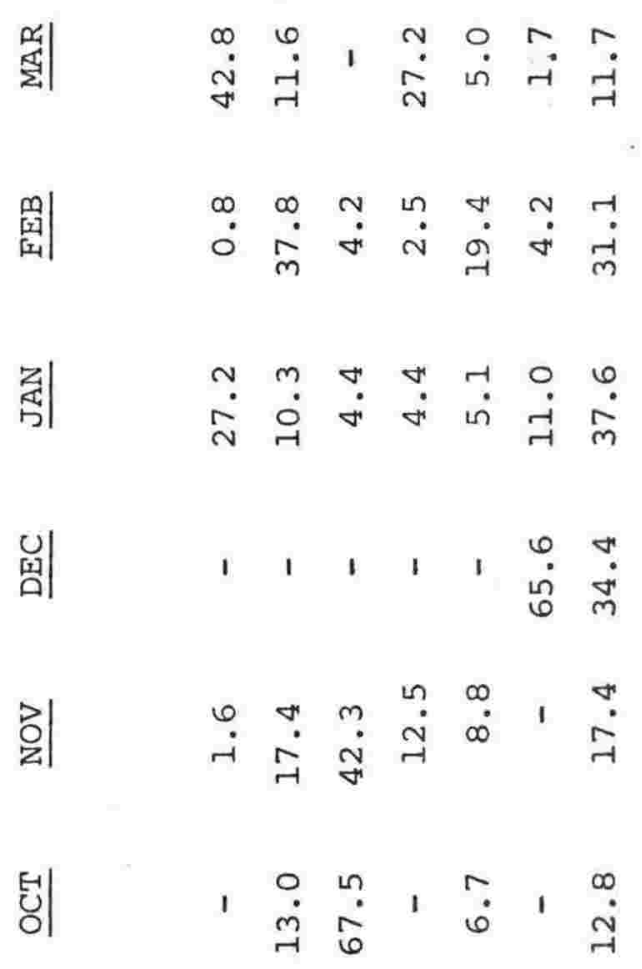

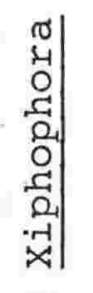

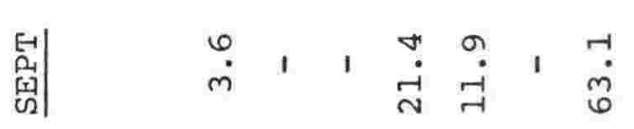

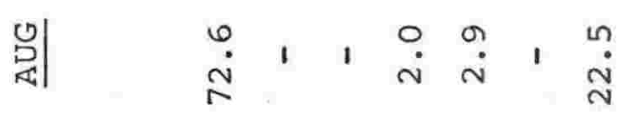

द્1

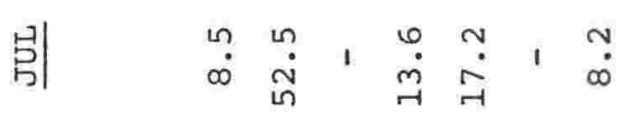

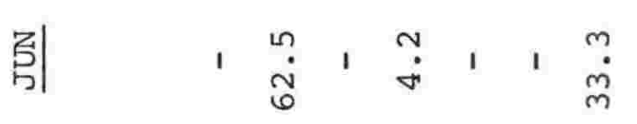

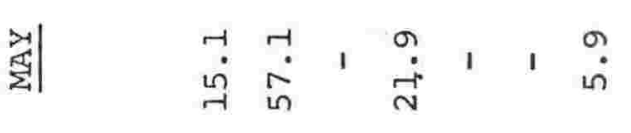

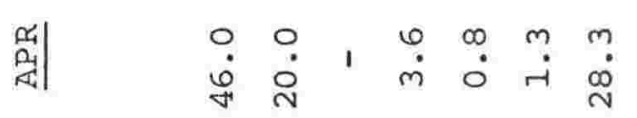

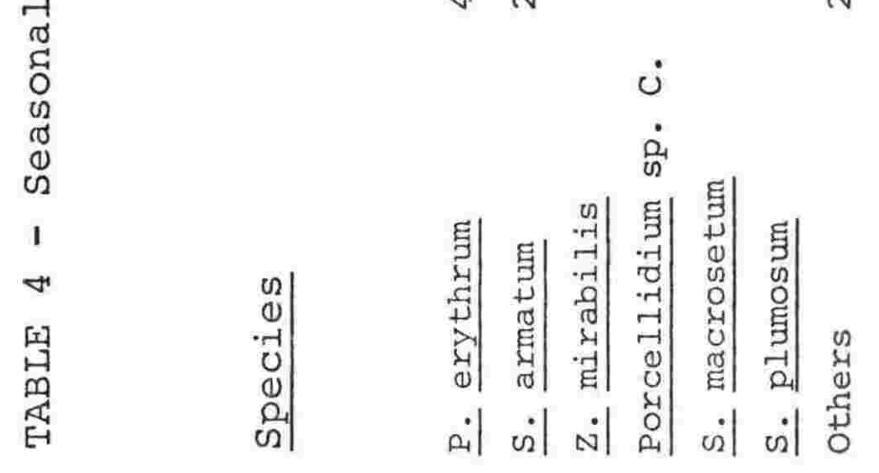


represented $72.6 \%$ of the harpacticoids associated with Xiphophora in August (Table 4). Average population density over the year was $3.1 .10 \mathrm{~cm}^{-2}$.

\section{$\frac{\text { Pterocladia }}{\text { assemblage }} \frac{\text { Iucida }}{(\text { Fig. } 7)}$}

A distinct summer maximum occurs in the harpacticoid population density on pterocladia (Fig. 7). This peak reached $66.10 \mathrm{~cm}^{-2}$ in February and proceeded to decline in March. A further increase in May $\left(14.10 \mathrm{~cm}^{-2}\right)$ occurred prior to the winter decline when the lowest overall densities were observed $\left(7.10 \mathrm{~cm}^{-2}\right)$. Two peaks in total numbers of about $40.10 \mathrm{~cm}^{-2}$ occurred before the summer maximum. Annual mean population density for the Pterocladia assemblage was $29.8 .10 \mathrm{~cm}^{-2}$.

The presence of small levels of deposited sediments influences the species composition in a way similar to the Corallina assemblage.

\section{Harpacticus pulvinatus Brady (Fig. 7).}

Fluctuations in the seasonal population density were, like Zausopsis mirabilis, between 1 and $6.10 \mathrm{~cm}^{-2}$ with the annual maximum occurring in November $\left(11.10 \mathrm{~cm}^{-2}\right)$. At this time it comprised $25.2 \%$ of the population (Table 5). Two further smaller peaks were observed in May and September, both with densities of $6.10 \mathrm{~cm}^{-2}$. H. pulvinatus accounted for $13.2 \%$ of the total population on pterocladia (Table 8). The mean annual population density was the same as $\underline{\text { Z. mirabilis }}\left(3.4 .10 \mathrm{~cm}^{-2}\right)$. 
100.

FIG. 7 - Seasonal variation in population density of the harpacticoids associated with the alga Pterocladia lucida. Monthly values represent the mean of two and sometimes three replicate samples taken from April 1973-March 1974. 


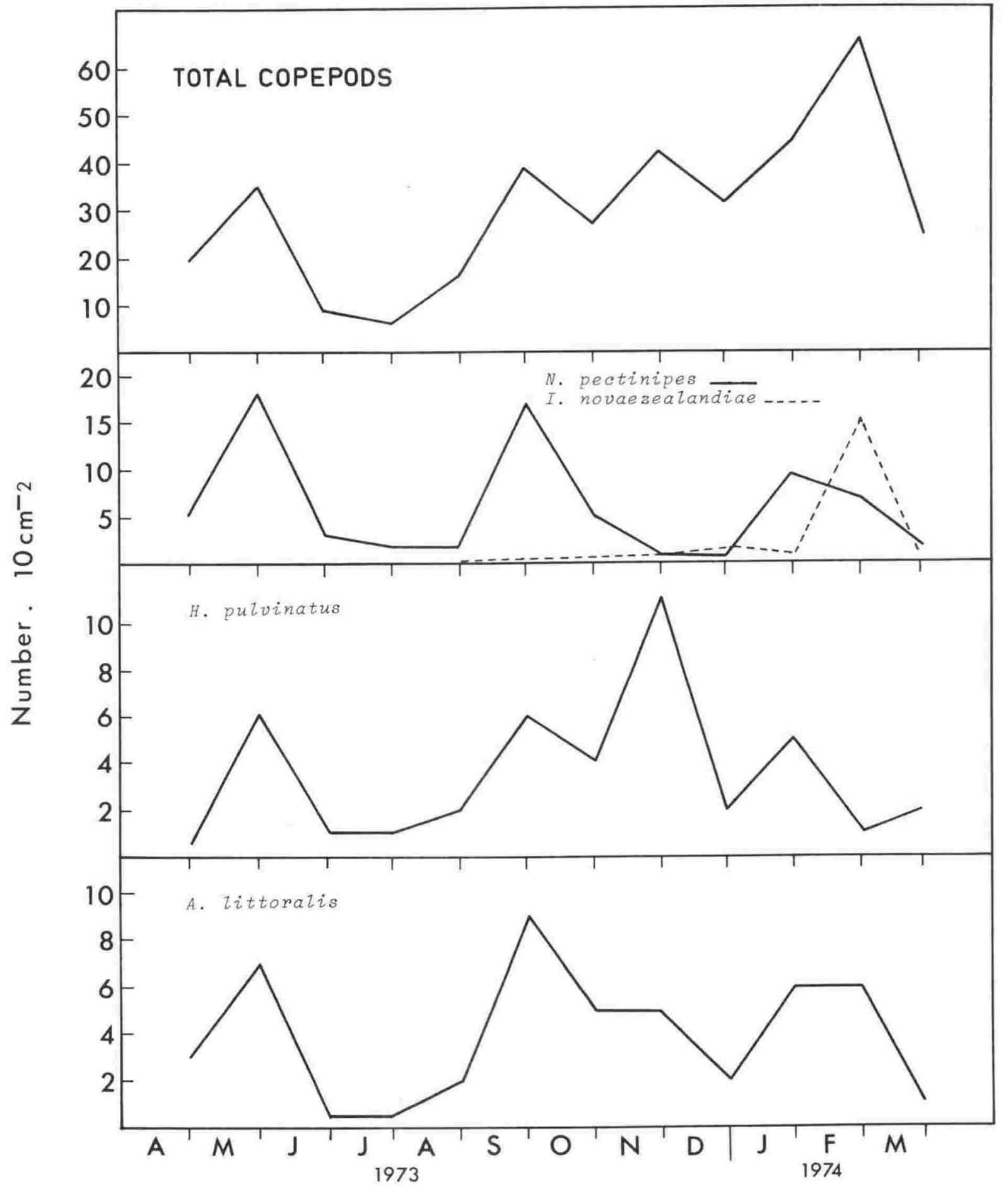




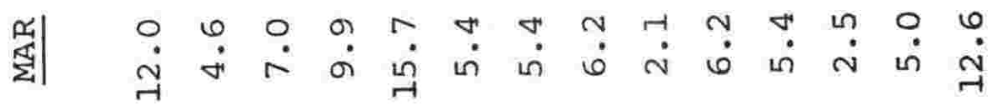

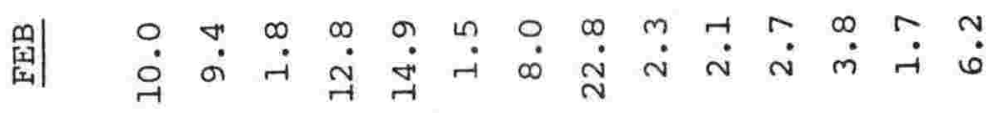

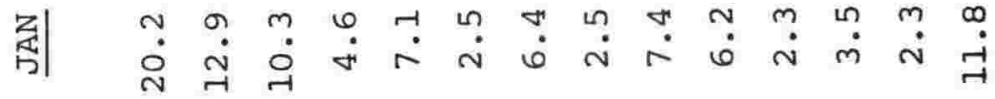

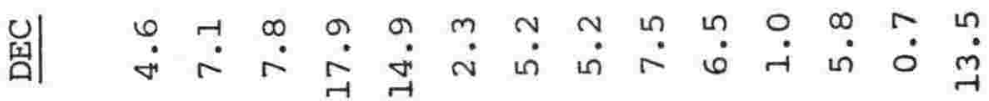

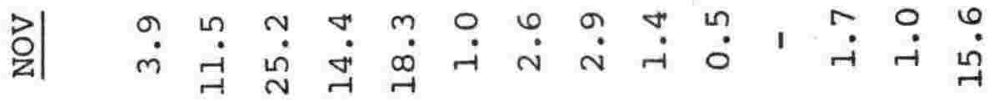

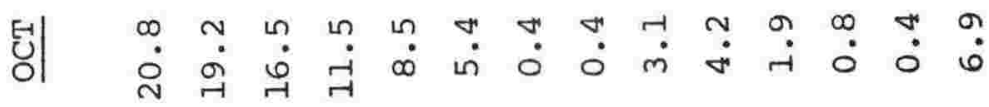

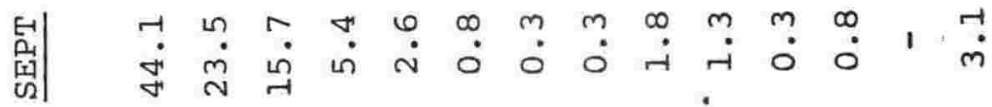

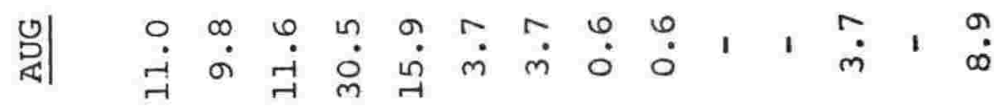

ธ

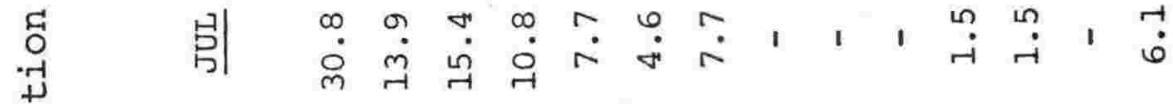

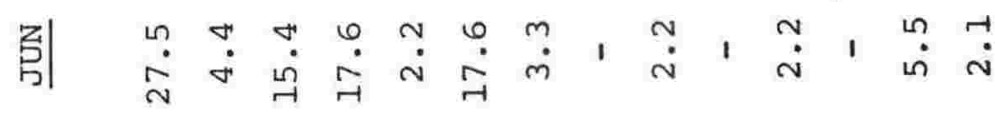

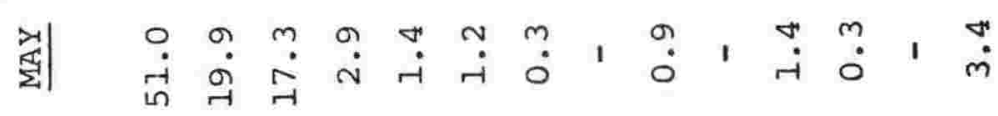

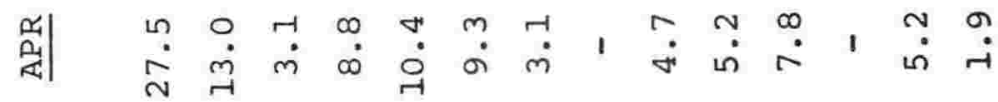

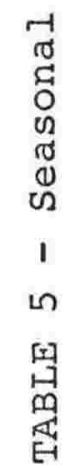

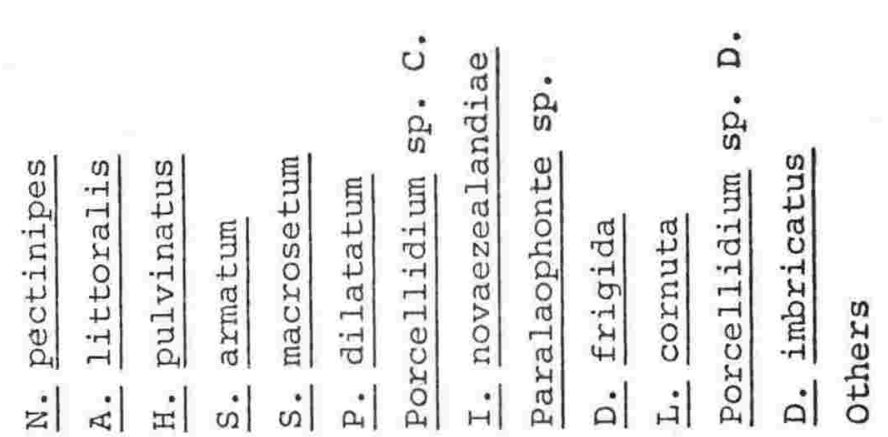


Alteutha littoralis Pallares (Fig. 7).

Like $\underline{H}$. pulvinatus, the numbers of $\underline{A}$. littoralis fluctuated little during the year. The apparent maximum density was in September $\left(9.10 \mathrm{~cm}^{-2}\right)$ and the mean annual abundance was $3.8 .10 \mathrm{~cm}^{-2}$. Lack of any sizeable peaks, like Eupelte regalis, is probably related to the continuous high level of reproductive activity observed in these species (Hicks in press b). Although $\underline{\text { A. }}$ littoralis was the second most abundant species on Pterocladia, at no time did it proportionately outnumber other associated species (Table 5).

Neopeltopsis pectinipes Hicks (Fig. 7).

A distinct polymodal distribution was evident in the population density of $\mathrm{N}$. pectinipes. Three peaks occurred, the first in May and the second in september $\left(18\right.$ and $17.10 \mathrm{~cm}^{-2}$ respectively). A decline followed the latter peak but a further increase in numbers took place in January $\left(9.10 \mathrm{~cm}^{-2}\right)$. N. pectinipes was the seasonal dominant and the most important constituent of the Pterocladia assemblage for 7 months of the year. It comprised $51 \%$ of the total population in late autumn (Table 5). An average population density over the year of $6.2 .10 \mathrm{~cm}^{-2}$ was recorded.

Idomene novaezealandiae Thomson (Fig. 7).

I. novaezealandiae made its appearance in the population in August but did not begin to increase in abundance until the summer. Maximum density was in February $\left(15.10 \mathrm{~cm}^{-2}\right)$ when it was the most conspicuous member of the harpacticoids on Pterocladia (Table 5). In April the species disappears. Mean annual abundance was only $1.8 .10 \mathrm{~cm}^{-2}$. 


\section{$\frac{\text { Ecklonia }}{\text { assemblage }} \frac{\text { (Fig. } 8)}{(\text { igta }}$}

Total population densities of the copepods on Ecklonia were so low that figures have been expressed in numbers $.100 \mathrm{~cm}^{-2}$. From April to October the mean population density was $17.4 .100 \mathrm{~cm}^{-2}$, rising to the seasonal maximum of $60.100 \mathrm{~cm}^{-2}$ in November. The most important components of this late autumn peak were Paramphiascella sp., Z. mirabilis, and parathalestris sp. (Table 6). Numbers declined during December but rose to a subsidiary peak of $31.100 \mathrm{~cm}^{-2}$ in January. The mean annual population number was $22.100 \mathrm{~cm}^{-2}$. No species encountered on Ecklonia could be considered distinctive elements of the Ecklonia assemblage and they have therefore been omitted from individual analysis. Their population densities were very low at all times and variability between individual species was of little consequence. Species occurring on Ecklonia appear periodically during the year and may usually be considered vagrants, probably being swept there from another algal substrate. Any analysis based on such occurrences and their variations would thus be misleading.

\section{SPECIES DOMINANCE}

The total abundance (total number of individuals of each species collected from respective algae), the percentage frequency and the percentage dominance for the 'important' species of each alga are given in Table 8. 'Important' species in this context are those representing an annual percentage species composition of over 5\%, calculated from Tables 1-6. Percentage occurrence of rarer species may be calculated from Table 7. Dominance and frequency indices are derived from each species as: 
FIG. 8 - Seasonal variation in population density of the harpacticoids associated with the alga Ecklonia radiata. Monthly values represent the mean of duplicate samples taken from April 1973-March 1974. 


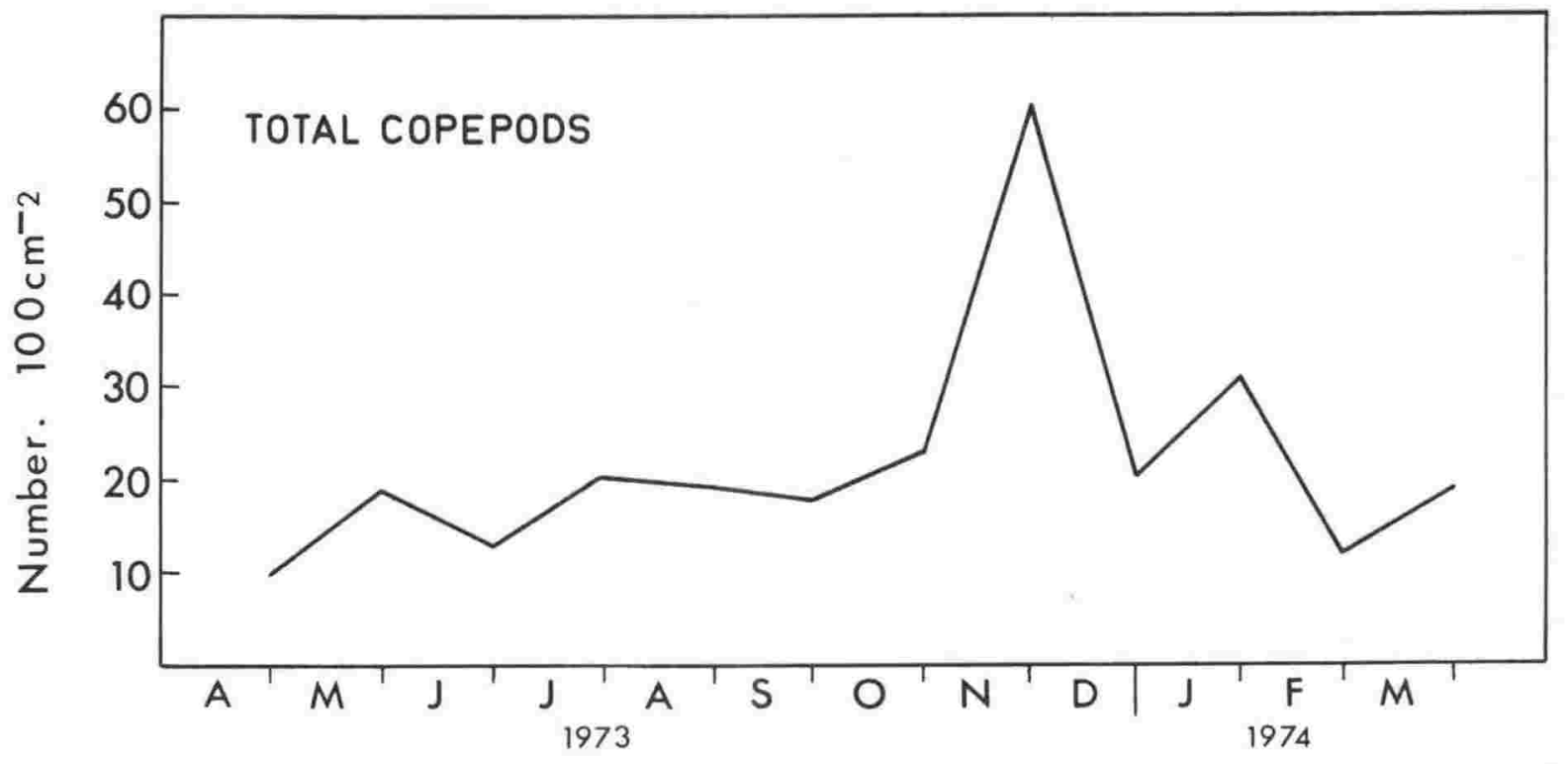




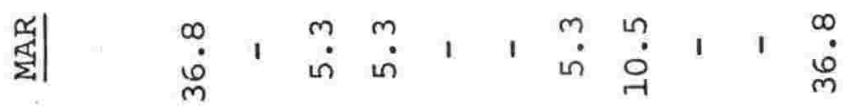

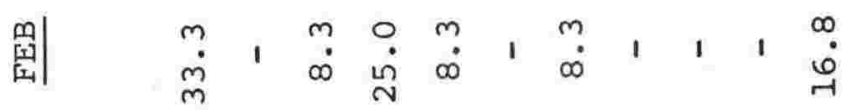

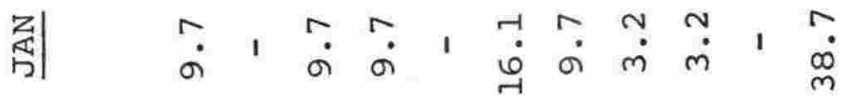

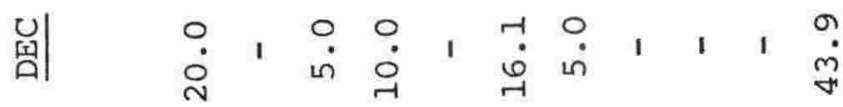

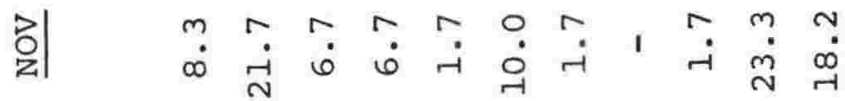

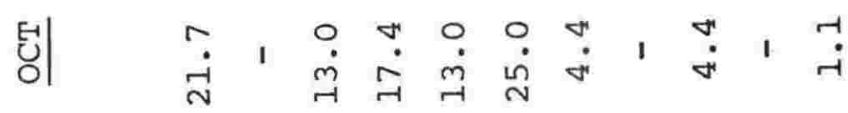

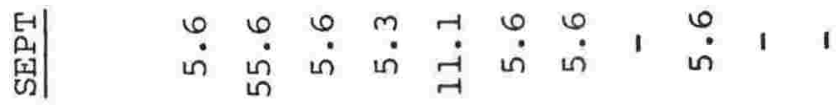

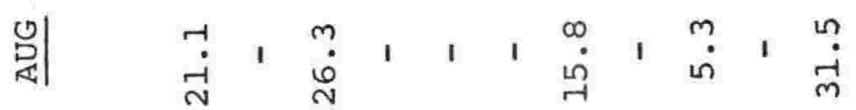

ธี

7
0
-71
-1
-1
02
0
0
0
0
0
0

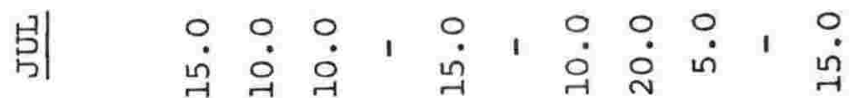

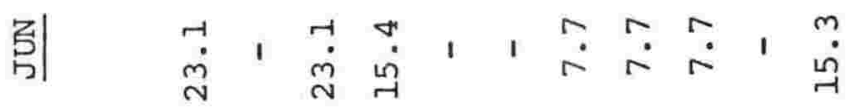

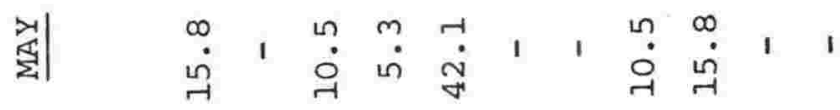

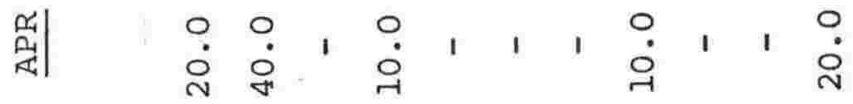

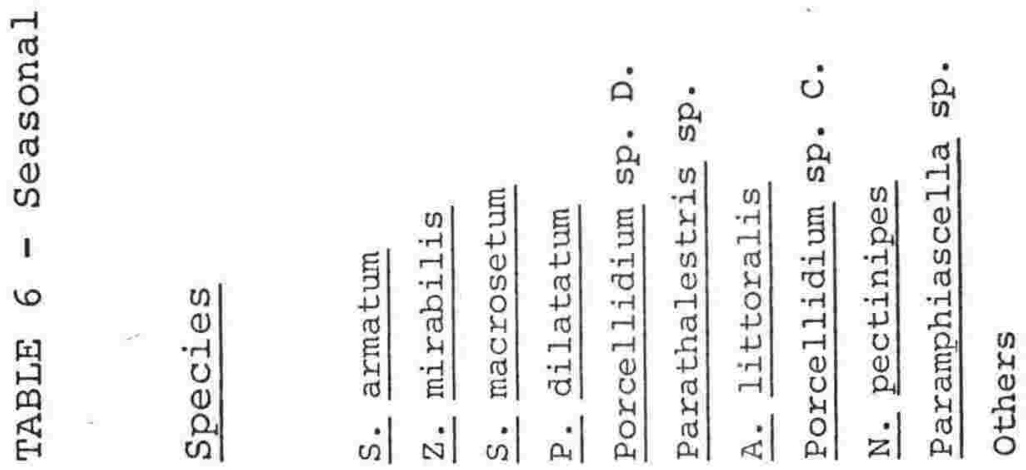


व்

- 010

00

茾

U U

त)

Q 0

\%

政

岳昰

न्न

त्- 4

范

U

त्र

or

त $~$

0

가담

ल

○

政

न +

남

(1) 计

党

4 is

0 党

थ

(4) 음

()

萼 N

द

म 4

r

70

U

(1)

त्व

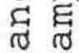

0 $\backsim$.

U)

(1)

4 U

पद ¿

บ 0 मू

0 , 0

O

a $\pi 0$

(1) 0

- 0 ,

(1)

$\Omega, 0 \cdot r$

红冮

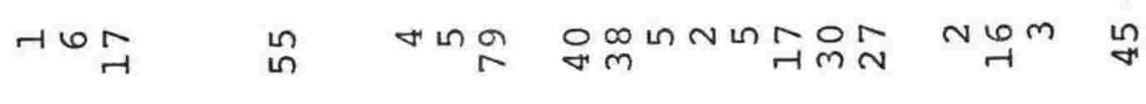

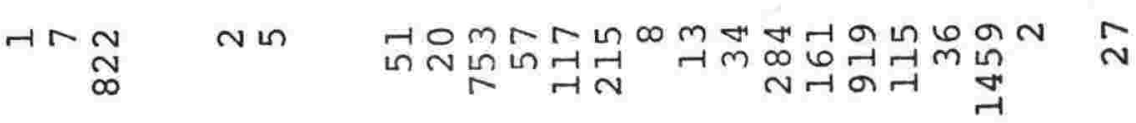

riv

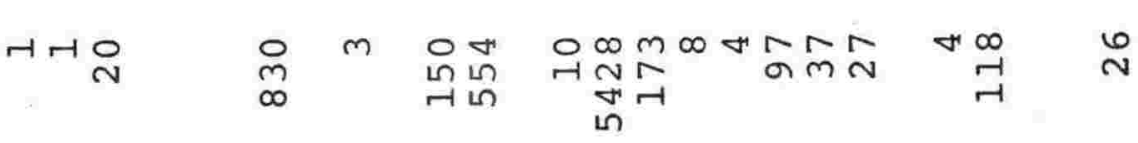

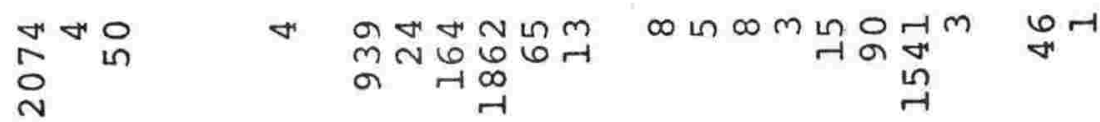

a $\rightarrow m \sim m$

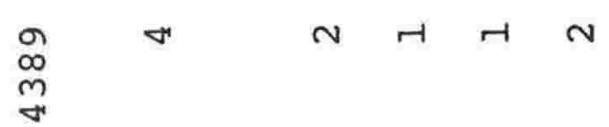

N

蚂

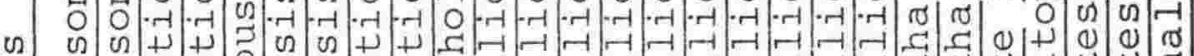

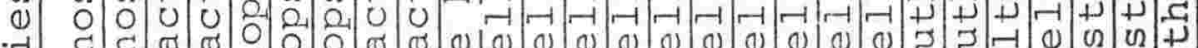

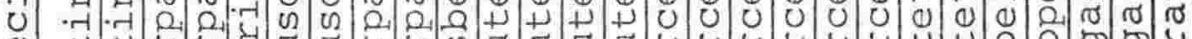

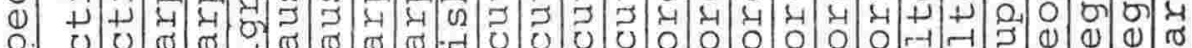

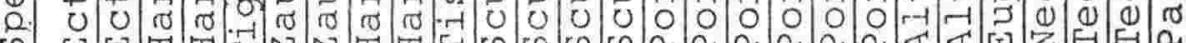

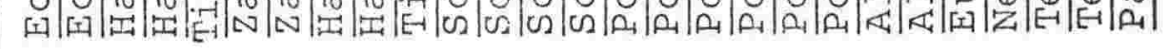




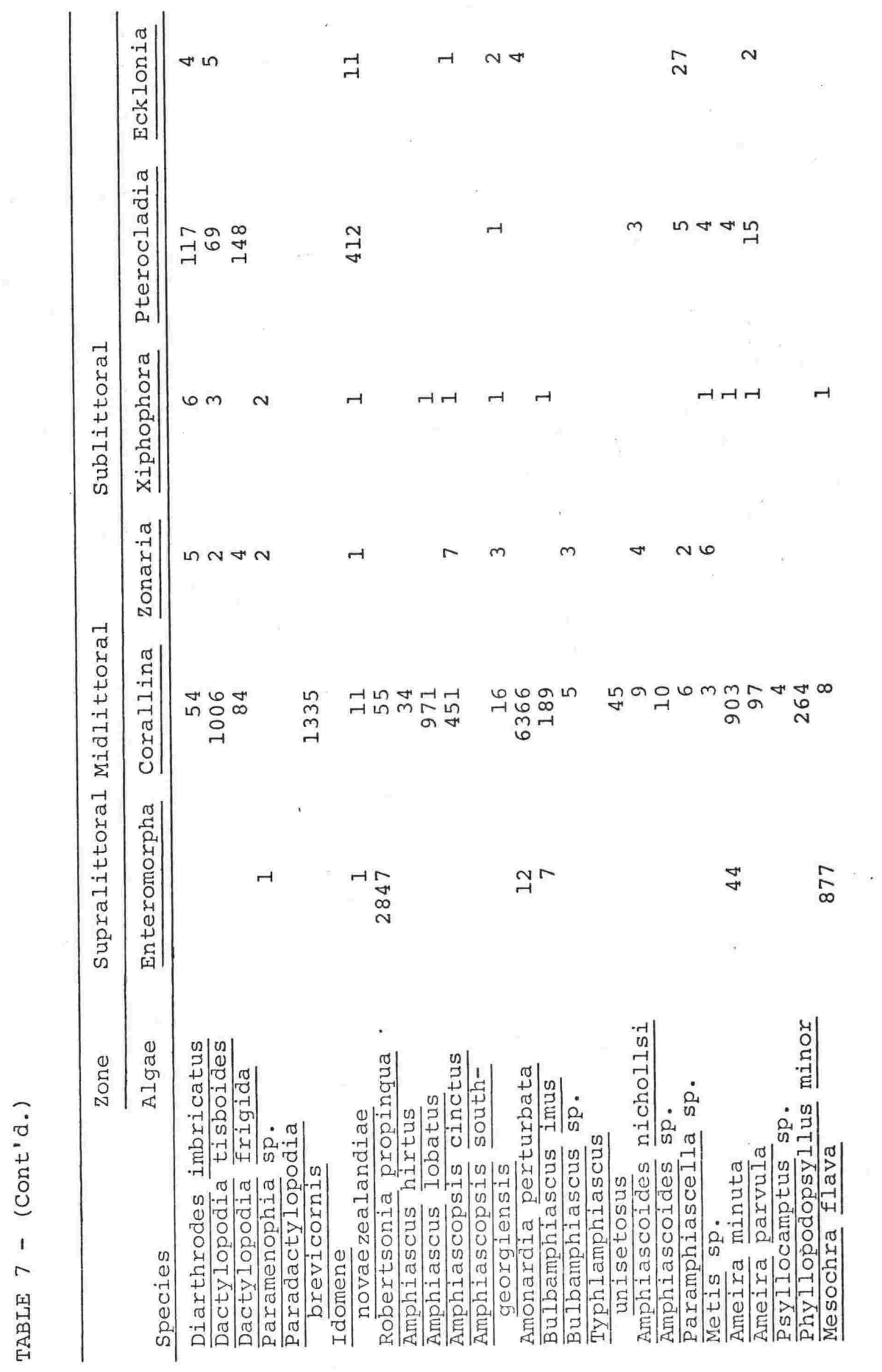




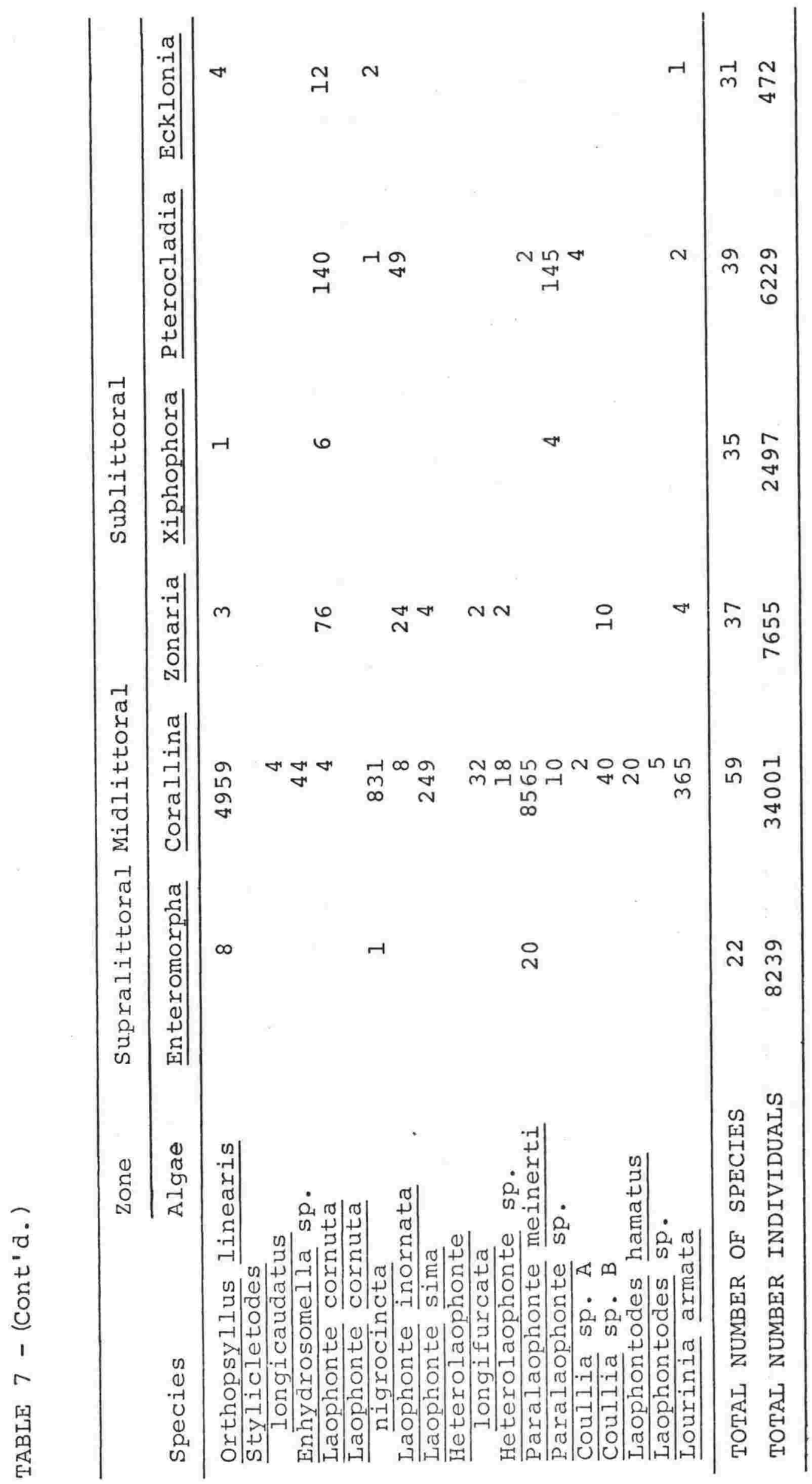


TABLE 8 - Dominance ranking and frequency of occurrence of the important species from each alga. Based on species representing more than $5 \%$ of the mean annual percentage composition. Figures in parentheses represent the number of samples taken of each alga.

SPECIES

TOTAL NUMBER COLLECTED
$\%$ FREQUENCY DOMINANCE

ENTEROMORPHA (22)

$$
\begin{aligned}
& \frac{\text { T. }}{\text { R. holothuriae }} \\
& \frac{\text { M. }}{\text { flavinqua }}
\end{aligned}
$$

4389

2847

877

CORALLINA (27)

$$
\begin{aligned}
& \text { P. meinerti } \\
& \text { A. perturbata } \\
& \text { O. } \frac{\text { linearis }}{\text { Eustrale }} \\
& \text { E. } \frac{\text { susinatum }}{\text { S. }} \\
& \text { E. } \frac{\text { regalis }}{}
\end{aligned}
$$

ZONARIA (29)

$$
\frac{\text { P. }}{\text { Z. }} \frac{\text { dilatatum }}{\text { Sirabilis }}
$$

XIPHOPHORA (24)

$$
\begin{aligned}
& \frac{\text { P. erythrum }}{\text { S. } \frac{\text { armatum }}{\text { Zirabilis }}} \\
& \frac{\text { Por. }}{\text { cellidium }} \mathrm{sp} \cdot \mathrm{C} \\
& \frac{\text { S. macrosetum }}{\text { S. }}
\end{aligned}
$$

PTEROCLADIA

\section{(28)}

$$
\begin{aligned}
& \frac{\text { N. }}{\text { A. }} \frac{\text { pectinipes }}{\text { littoralis }} \\
& \text { H. } \frac{\text { pulvinatus }}{\text { S. }} \\
& \text { S. }
\end{aligned}
$$

8565

6366

4959

2074

1862

1541

5428

830

554

705

542

449

315

98

40

1459

919

822

753

117
100

100

100

89

93

100

100

86

90

70.9

10.8

7.2

ECKLONIA (24)

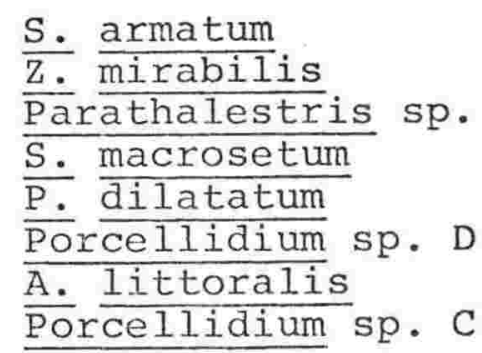

$50 \quad 3.6$




$$
\begin{aligned}
& \text { DOMINANCE }=\frac{\text { total no. specimens of a species }}{\text { total no. specimens in collection }} \times 100 \\
& \text { FREQUENCY }=\frac{\text { no. of samples in which species occurred }}{\text { total no. of samples }} \times 100
\end{aligned}
$$

In each of the six algal habitats there are dominants, both in abundance and frequency of occurrence (Table 8). The overall dominant species was paralaophonte meinerti, which accounted for $14.5 \%$ of the total harpacticoids collected in this study, in spite of occurring on only three algae. A preference for sediments restricts the species primarily to Corallina where it forms a quarter of the total annual fauna (Table 8). Subdominants Amonardia perturbata and Orthopsyllus linearis together form a third of the Corallina harpacticoids. These species similarly are common inhabitants of algae and sediments in the southern hemisphere (de Bovée et al. 1973, Pallares \& Hall $1974 \mathrm{a}$, personal observations).

Porcellidium dilatatum comprised $70.9 \%$ of the copepods on zonaria and is the highest relative percentage abundance of any species studied. An indication of the importance of Robertsonia propinqua to the Enteromorpha assemblage can be gained by the total annual abundance which spanned only 6 months, resulting in the species comprising $35.6 \%$ of the fauna.

The majority of Ecklonia and Xiphophora dominants are also shared by other algae. Similarities in the species composition between these algae and others can be largely attributed to the commoner eurytopic species e.g. Scutellidiumarmatum, s.

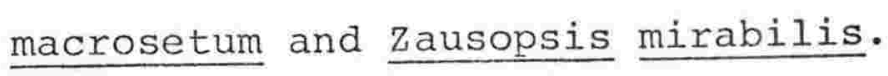




\section{SPECIES ASSOCIATIONS}

For determination of the species which are closely associated a matrix of affinity was derived (Fig. 9). This procedure is a semi-quantitative expression of the percentage relationship of the species between samples. Trellis diagrams or matrices of affinity have been used extensively by other workers on meiofauna (Wieser 1960, Hopper \& Meyers 1967, Soyer 1970, Warwick \& Buchanan 1970, Coul1 1972, Marcotte \& Coull 1974). A description of the method is given in sanders (1960) and Stephenson (1972). Hicks (in press a) comments on the method as it applies to this study.

The similarity matrix has made use, in this case, of all data based on the percentage of co-occurrence of species with a total sampled number of 200 or more individuals. Disregarding species below this figure clarifies the matrix and eliminates the problem of overvaluing rare or uncommon species.

A high degree of association is observed between Porcellidium dilatatum, Scutellidium armatum, S. macrosetum, S. plumosum, Porcellidium sp. C. and Alteutha littoralis, (Fig. 9). These species are associated over $40 \%$ of the time with the latter five species co-occurring in upwards of $50 \%$ of the samples. These harpacticoids may therefore be termed characteristic of the marine algal biotope at Island Bay, their regular occurrence forming a homogeneous group of species indicative of that biotope. The high degree of association exhibited by P. dilatatum requires further comment. 'Although this species occurs frequently with others in the above group the actual total numbers encountered on algae other than Zonaria is not high. Their presence in great numbers on Zonaria (Tables $7 \& 8$ ), however, suggests some form of active 
112 .

FIG. 9 - The association of harpacticoid species in the supralittoral, midlittoral and shallow sublittoral algal biotope at Island Bay, wellington. Affinity indices are based on co-occurrences expressed as a percentage of possible co-occurrences. 


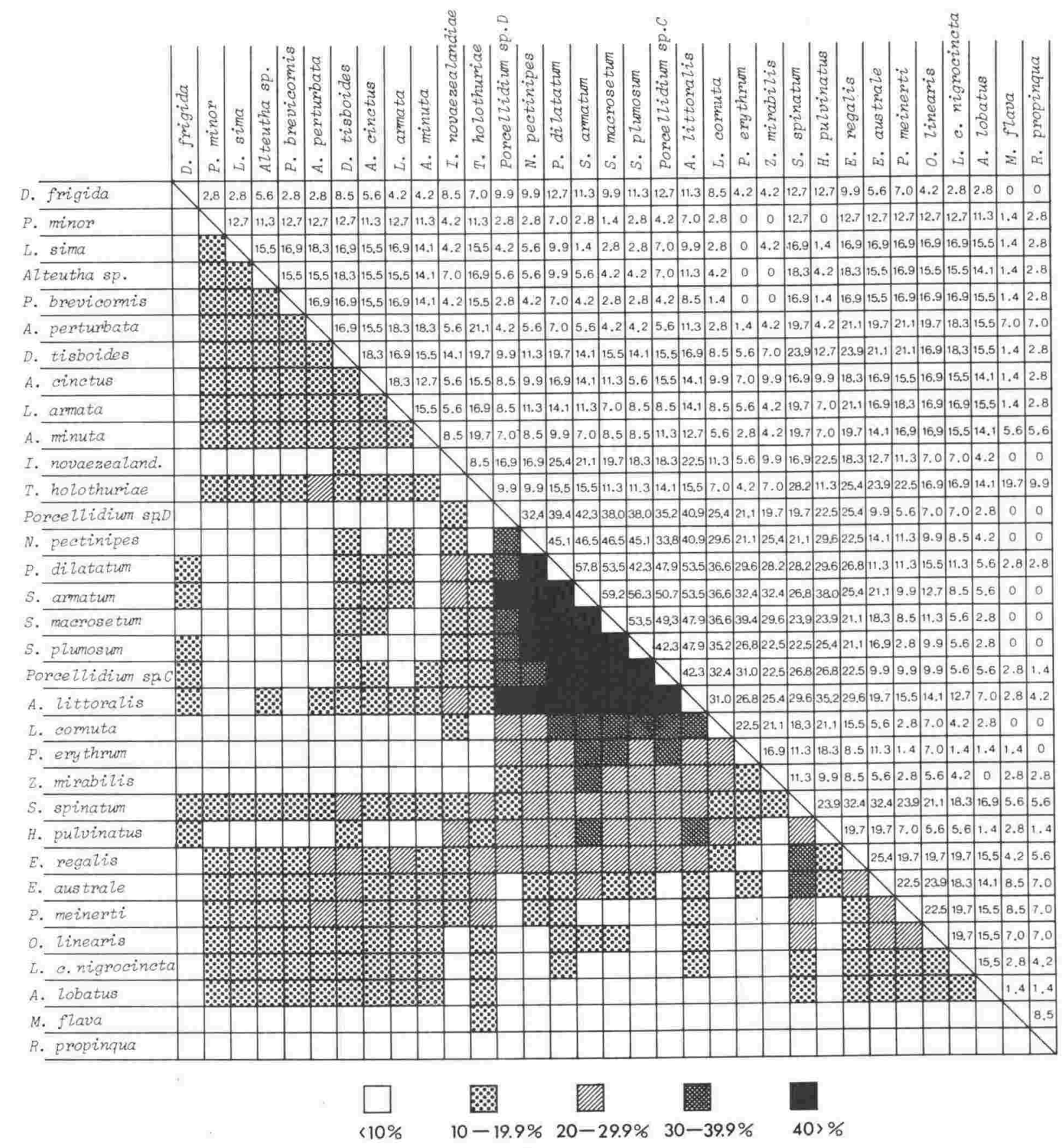


substrate selection. This observation is dealt with in detail elsewhere (Hicks in press c).

A second group of species associated with these indicators, but less consistently, are Neopeltopsis pectinipes,

Laophonte cornuta, Porcellidium erythrum, Zausopsis mirabilis, Scutellidium spinatum, Harpacticus pulvinatus and Eupelte regalis which co-occur in 20-40\% of the samples. Most of the remaining species associated at between 10 and $20 \%$ are those characteristic of the sediment-laden Corallina assemblage. The degree of affinity of component species is assumed to reflect their preferred habitat.

Habitat specialization and isolation of Mesochra flava and Robertsonia propinqua is evidenced by their low affinity indices. Co-occurrence takes place rarely by wave splash which introduces primarily adventitious species from the coralline zone into the supralittoral rockpools.

\section{DISCUSSION}

POPULATION DENSITY

From the quantitative point of view the mean harpacticoid densities recorded in this study are in general comparable with their counterparts in other biotopes, particularly that of fully marine level-bottom sands (see Hicks in press a, Tables $7 \& 8)$.

In the upper shore algal assemblages population densities ranged from 5 to 366 individuals $.10 \mathrm{~cm}^{-2}$ on Enteromorpha, while those from the heavily sediment laden Corallina assemblage were within $70-578.10 \mathrm{~cm}^{-2}$. These associations supported the highest densities of harpacticoids recorded in the present work. Studies which compare most favourably with 
the present numerical data are those of the sandy beach intertidal. Harris (1972a) recorded densities of $65-588.10 \mathrm{~cm}^{-2}$ at Whitsand Bay, Cornwall; Perkins (in McIntyre \& Murison 1973) noted $13-486.10 \mathrm{~cm}^{-2}$ at Whitstable, Kent; and Hulings' (1974) study of the Lebanese beach meiofauna revealed densities of $5-699.10 \mathrm{~cm}^{-2}$.

Although there are many exceptions, sublittoral environments tend to support lower densities of copepods than the same substrates intertidally (see McIntyre 1969, Hicks in press a, Tables $7 \& 8)$. It is to be anticipated, therefore, that shallow sublittoral algae have lower population densities. Zonaria, for example, which supports the highest mean annual copepod abundance of the sublittoral, has a range of only 11 to $86.10 \mathrm{~cm}^{-2}$. Copepod densities in excess of $150.10 \mathrm{~cm}^{-2}$ in fully marine sediments from comparable shallow depths have occasionally been reported (e.g. Coull 1970, Soyer 1970, Dinet 1972), but maximum densities are usually of a similar order to those of the phytal (e.g. Guille \& Soyer 1968, McIntyre \& Murison 1973). Widely differing sampling techniques make direct quantitative comparison of population densities with other studies on marine algae difficult. The results of two investigations which provide density data based on numbers $.10 \mathrm{~cm}^{-2}$ rock surface can be noted, but both suffer from a lack of seasonal data. Chapman (1955) estimated a density of 36 copepods $.10 \mathrm{~cm}^{-2}$ from the exposed coastal Corallina granifera while the results of Sarma \& Ganapati (1972) provide the highest recorded densities up until the time of this paper. Their analysis of the macrofauna and meiofauna inhabiting thirteen species of marine algae revealed copepod densities of up to $265.10 \mathrm{~cm}^{-2}$ on the protected bushy Dictyota dichotoma. 
The majority of the copepod species at Island Bay showed apparent seasonal changes in population density with maxima occurring at different times. There is little directly comparable quantitative information available on the seasonal changes in other algal dwelling harpacticoids. Accordingly, most comparisons will be made with the more extensively researched interstitial and epibenthic species.

Observed fluctuations in population density are largely attributable to reproductive activity of individual species (Hicks in press b). Little positive correlation between seawater temperature and copepod reproduction, with its consequent effects on population density, was observed, unlike the observations of Smidt (1951), Harris (1972a, b) and McIntyre \& Murison (1973). Harris (1972b) found a close relationship between high seawater temperatures in the summer and peaks of ovigerous females and copepodites. He also noted that offspring largely augmented numbers of adults resulting in higher summer population densities.

In this study the proportions of ovigerous females in each species was highly variable throughout a year but $40 \%$ of the species reached a maximum level in autumn (see Hicks in press b). In these species summer warming may stimulate females to produce eggs, but in general little direct correlation with temperature can be detected. Among species analysed for reproductive patterns, however, $80 \%$ showed maximum levels of copepodites and maximum numbers of eggs carried by each female during the spring and summer (Hicks in press b. Fig. 22). Of these, about $68 \%$ reached population density maxima during this period. High numbers of copepodites in each species often accounted for coincident or subsequent maxima in the density of such species 
populations. For example, in Robertsonia propinqua, Amonardia perturbata, Paralaophonte meinerti and Harpacticus pulvinatus copepodites contributed directly to high population density; while in others e.g. Porcellidium dilatatum, orthopsyllus linearis, Ectinosoma australe maximum densities were recorded shortly after copepodite peaks. In cases of asynchronous population density maxima, that is, those which do not closely follow the reproductive peaks (e.g. Tisbe holothuriae) a number of factors could be responsible. Among those suggested are failure of the previous years spawning, interspecific competition or mortality caused by some other agency, or an extended development period of the young. Regular sampling over two or more years may well provide more direct evidence. Production of the majority of young during the spring and summer could coincide with a greater abundance of food which advantageously affects the rates of maturation, egg production, egg-laying and naupliar development (see Hicks in press b). In combination with higher temperatures adequate food may lead to more rapid growth. Differing physiological responses to food and temperature result in the reproductive activity of some species occurring during the coldest part of the year (Autumn to spring), leading to population density peaks around this time e.g. A. perturbata and paradactylopodia brevicornis. These and other species (Scutellidium spinatum, O. linearis, Laophonte cornuta nigrocincta, Amphiascus lobatus, Lourinia armata and Amphiascopsis cinctus) are in great abundance during the winter. Unlike the direct high temperature/high population density correlations exhibited by most of the interstitial copepods of Harris (1972a), other authors have recognized pronounced increases in population densities in winter, spring and autumn 
for sediment-dwelling harpacticoids (e.g. Muus 1967, Barnett 1970, Coull 1970, Lasker et al. 1970, McIntyre \& Murison 1973 and de Bovée \& Soyer 1974). Furthermore, algal-dwelling copepod populations have exhibited similar variability in the period of maximum abundance (e.g. Ohm 1964, Hagerman 1966 , Mukai 1971, Pallares \& Hall 1974a).

\section{SPECIES ASSOCIATION AND ASSEMBLAGE CHARACTERISATION}

The species associations provide evidence of distinct taxo-ecologic 'types' of harpacticoids which characterize the marine algal biotope. All species with affinity indices above $30 \%$, with the exceptions of Ectinosoma australe and Laophonte cornuta, belong to either the Harpacticidae, Tisbidae, Porcellidiidae or Peltidiidae, (Fig. 9) which represent 25\% of all the families and $18 \%$ of all the genera collected (see Hicks in press a). These families fall within the distinctively phytal-dwelling forms of Remane (1952) and Noodt (1957, 1971): Thalestridae, Harpacticidae, Diosaccidae, Tisbidae, Porcellididae, Peltidiidae and Tegastidae. Of these the most conspicuous and specialized members (Porcellidiidae, Peltidiidae and Tisbidae) are ovoid to sub-ovoid in shape and show varying degrees of dorso-ventral flattening.

Each algal habitat is characterized by species morphologically and physiologically adapted to preferred substrates. The algae Zonaria, Xiphophora, Pterocladia, Ecklonia and Enteromorpha are all dominated by species belonging to one of four typical phytal families. Whereas Corallina is dominated by families more characteristic of the sediment meiobenthos (e.g. Laophontidae, Canthocamptidae, Ectinosomidae and Diosaccidae) (Table 8) probably because of high levels of sediment in the holdfasts. 
The Corallina association may be considered compartmented or stratified into two apparently distinct 'microhabitats'. A thick layer of detritic sandy sediment is trapped and bound at the bases of Corallina and supports a distinctive fauna of epistrate and burrowing species. The nature and species composition of this stratum is more reminiscent of the levelbottom sediment meiobenthos yet it is devoid of the truly interstitial component. This may well be due to the reduced pore space owing to the poorly sorted nature of the sediment (see Hulings \& Gray 1976), which has a high level of fine material (see Hicks in press a, Fig. 5).

Assemblage dominants such as $\underline{P}$. meinerti, A. perturbata, O. linearis and $\underline{E}$. australe as well as many other forms characteristic of marine sediments e.g. Phyllopodopsyllus, Laophontodes, Stylicletodes, Enhydrosomella and members of the Ameiridae, Diosaccidae and Laophontidae constitute the majority of the species which dwell there. The short tufted algal fronds represent the second stratum where the fauna is comprised mainly of S. spinatum, E. regalis some thalestrids, diosaccids and some laophontids. Itinerant species such as $\underline{L}$. armata and A. cinctus, although mainly found inhabiting the holdfast sediments also frequently occur amongst the fronds. Spatial separation of this kind could ensure a reduction in crowding and competition between associated species during periods of high population density. A consequence would be a more efficient use of the available habitat resources. Furthermore, a striking seasonal partitioning of population density maxima for the major species occurs within the Corallina assemblage. (Table 9). The timing of reproductive maxima varies amongst these species (Hicks in press b) and results in a succession of 

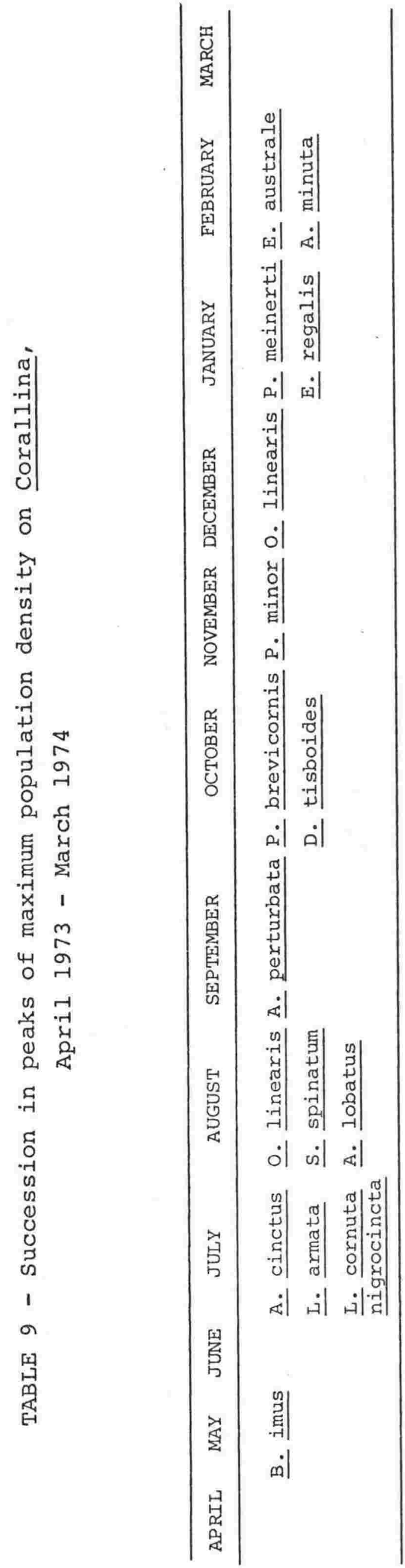
maxima of abundance. Two frond-dwelling species have been superimposed (Fig. 3) to show density relationships. Competition between the abundant $\underline{P}$. meinerti and $\underline{E}$. regalis (Table 9) may be avoided by spatial separation, and competition with another frond-dweller (Dactylopodia tisboides) during periods of high abundance may be avoided temporally. Similar observations have been made by Heip (1971, 1973) and Coull \& Vernberg (1975). The concept of parallel assemblages or 'isocommunities' proposed by Thorson (1957) to explain spatial similarities in the macrobenthos merits further discussion. This has recently received support with respect to the meiofauna from Por (1964), Coull \& Herman (1970) and Soyer (1970). 'Iso-communities' are recognisable when a series of sometimes geographically separate taxo-ecological homologues evolve in the presence of the same or very similar bottom types. In other words similar substrates are likely to be inhabited by animal associations consisting of different species of the same genus which may replace each other as the characterizing species.

An analysis of Island Bay faunal assemblages on sublittoral algae revealed, on Zonaria, an association dominated by Porcellidium dilatatum and Scutellidium armatum together forming over $78 \%$ of the fauna on this weed. Faunal assemblages on the fronds of Macrocystis from Santa Cruz, Argentina (Pallares \& Hall 1974b) are dominated by porcellidium rubrum and Scutellidium deseadensis, which constitute over $90 \%$ of the fauna at each of their two stations. The Island Bay sublittoral algae considered here all show parallel dominant species composition. In these terms the phaeophytes zonaria and Xiphophora may be considered close equivalents of the Argentina Macrocystis (Table 10). The dominant species on Xiphophora 
(Porcellidium erythrum) is closely related taxonomically to P. rubrum from Santa Cruz Macrocystis (Hicks 1971).

Harpacticus pulvinatus is one of the most important species inhabiting Pterocladia and Scutellidium armatum may correspond to the European parallel S. longicauda (Table 10, see Por 1964). The presence of the two important members of the Peltidiidae on Pterocladia agrees with the typically phytal characteristic of this alga, but the regular occurrence of thalestrids and laophontids suggests a notable level of sedimentation (see Table 7). Thus Por's (1964) phytal 'isocommunity' is based on species more characteristic of silted algae from more sheltered localities unlike the cleaner weeds of exposed coasts such as those found on Zonaria and Xiphophora.

Distinctive faunal assemblages of carbonate sediments or "coralline sands" have been recognized by Por (1964) and Coull \& Herman (1970) to include the diosaccid genera Rhyncholagena, Robertgurneya and some tetragonicipitids. Furthermore, the species Amphiascopsis cinctus, Orthopsyllus linearis, Robertgurneya rostrata, Paralaophonte brevirostris and Laophonte cornuta are important specific elements. The medium grade $(1.41 \varnothing)$ sandy sediments associated with the coralline algae at Island Bay have only a moderate carbonate fraction (12.5\%) and therefore differ from those found by coull. However, the coralline algal sediments contained all of the above genera, and some of the species, with the exception of Rhyncholagena (Table 11). Paralaophonte meinerti and $\underline{0 .}$ linearis are two of the predominant species comprising the Corallina assemblage. The reason the Tetragonicipitidae are not dominant elements in this fauna, unlike that found by Coull \& Herman (1970), is most probably related to the rather low carbonate level and 
TABLE 10 - Comparison of phytal parallel assemblages.

\begin{tabular}{|c|c|c|}
\hline $\begin{array}{l}\text { European algae } \\
\quad \text { (Por 1964) }\end{array}$ & $\begin{array}{l}\text { Argentina, fronds of } \\
\text { Macrocystis (Pallares } \\
\text { \& Hall 1974b) }\end{array}$ & $\begin{array}{l}\text { Island Bay, } \\
\text { Sublittoral algae }\end{array}$ \\
\hline
\end{tabular}

Harpacticus gracilis
Phyllothalestris mysis
Scutellidium longicaud
Parastenhelia spinosa

Amphiascopsis cinctus

Ectinosoma melaniceps

Alteutha

Peltidium

Porcellidium

$\underline{\text { Diarthrodes }}$

Heterolaophonte

Tegastes
Amphiascoides subdebilis Paramphiascella sp.

Ectinosoma melaniceps

Alteutha austrina

Porcellidium rubrum

Heterolaophonte tenuispina Laophonte cornuta
Tegastes sp. A

Harpacticus pulvinatus

Parathalestris sp.

Scutellidium armatum

Ectinosoma australe

Alteutha littoralis

Neopeltopsis pectinipes

Porcellidium dilatatum

Diarthrodes imbricatus 
TABLE 11 - Comparison of 'coralline sand' parallel assemblages.

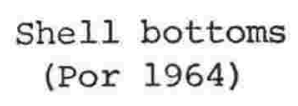

Shell bottoms

(Por 1964)

\author{
Carbonate sand \\ (Coul1 \& Herman 1970)
}

Island Bay,

Corallina algal sediments

\section{Rhyncholagena Robertgurneya rostrata}

Bulbamphiascus imus

Tetragonicipitidae

Amphiascopsis cinctus

Orthopsyllus linearis

Paralaophonte brevirostris

Laophonte cornuta

\section{$\left.\frac{\text { Rhyncholagena }}{\text { Robertgurneya }} \frac{\text { pestai }}{\text { rostrata }}\right\}$ Amonardia perturbata}

Bulbamphiascus imus

Phyllopodopsyllus hermani Phyllopodopsyllus minor

Amphiascopsis cinctus

Orthopsyllus linearis

Orthopsyllus linearis

Paralaophonte brevirostris
Paralaophonte meinerti

Laophonte cornuta nigrocincta 
slightly finer grain size of coralline algal sediments. Nevertheless, Corallina sediments are faunistically in close parallel to shell bottoms but differ in terms of the relative importance of generic forms and the absence of apparent indicators such as Rhyncholagena and Robertgurneya. Despite this the Diosaccidae remain the subdominant family.

Although two apparent parallel assemblages are observed in the present study (that of the sublittoral phytal and of coralline algal sediments) it is important to recognize the presence of transitional environments. In the case of the sublittoral algae these transitions may be detected by the regular presence of genera or species more typical of sediments. A moderate degree of faunal similarity ( $44 \%$ ) is seen, for example, between Corallina and Pterocladia which differ not only in their position on the shore and hence degree of exposure to wave action, but also in their growth form characteristics (see Hicks in press a). The shrubby form of pterocladia results in an increased surface area and consequently a greater propensity for trapping and binding sediments than is the case with Zonaria, Xiphophora or Ecklonia. Strictly phytal copepods do not appear to be greatly influenced by the amount of sediment in the algae, but other species more commonly found in sedimentary environments are normally only found in association with those algae which contain quantities of sediment (see Table 7). Hence pterocladia offers a sedimented habitat which is a necessary requirement to support faunal elements found predominantly on Corallina e.g Diarthrodes imbricatus, Dactylopodia tisboides, Dactylopodia frigida, Alteutha sp. 
The very nature of transitional environments may be responsible for observed changes in dominant genera. For example, Por (1964) regarded Rhyncholagena as the characteristic genus of shell and gravel bottoms while Coull (see Coull \& Herman 1970) found carbonated sediments to be dominated by phyllopodopsyllus. In the present study Paralaophonte is the predominant member of coralline algal sediments. Nevertheless, all of these genera are considered typical of the 'coralline sand' isocommunity. In this case Amonardia has replaced Rhyncholagena and Robertgurneya as the characteristic diosaccid. Such variation in the assemblage dominant relates to the different habitat requirements reflecting small changes within the environment. Finer grain size and lower carbonate levels in coralline algal sediments probably selects for species more adapted to these conditions than they are to larger grain size and higher carbonate levels (see Coull \& Herman 1970).

population density maxima occur at different times throughout the year and relate to differing physiological responses to food and temperature which may influence reproductive activity of constituent species. Moreover high densities associated with the present Corallina appear to be the result of increased biotic space provided by the stratified condition of the assemblage. High algal surface areas plus high levels of bound sediments, which is related to the sheltered position on the shore, has increased the number of niches and their total area to allow the assemblage to carry an overall greater number of animals. Density figures therefore closely approximate those from level-bottom sediments. Greater exposure to wave action, lower habitable surface areas and lack of any effective sedimentation (except on Pterocladia) probably contributes to the lower densities on sublittoral algae. 
The similarity observed in the harpacticoid faunas of algal sediments and fronds between areas with similar substrates elsewhere further supports the evidence of Por (1964) and Coull \& Herman (1970) on the existence of parallel faunal assemblages. Since most species can tolerate a certain degree of substrate variability one should be cautious of classifying parallel assemblages as distinct faunal entities as has occurred with many 'classical communities'. Such classification should necessarily take into account the existence of transitional faunal zones.

In consequence the term "communities" has been avoided in this study in preference for more biologically meaningful terms such as species 'associations' or 'assemblages'. Such aggregations of species that occur on each alga have been analysed as independent associations related to the variable substrate of each alga. Boundaries of these associations are obscure and therefore defy placement within distinct algaldwelling copepod 'communities'.

\section{ACKNOWLEDGEMENTS}

This paper formed part of a Ph.D. thesis presented at Victoria University of Wellington under the supervision of Dr Robert G. Wear (Zoology Department). Dr Janet M. Bradford (N.Z. Oceanographic Institute) has provided valuable advice and encouragement during the course of this study and with Professor John B.J. Wells has constructively reviewed the manuscript. The first year of the study was carried out under the tenure of a N.Z. University postgraduate Research Scholarship from the University Grants Committee. 


\section{LITERATURE CITED}

BARNETT, P.R.O. 1968: Distribution and ecology of harpacticoid copepods of an intertidal mudflat. Internationale Revue der gesamten Hydrobiologie und Hydrographie 53: 177-209.

1970: The life cycles of two species of Platychelipus Brady (Harpacticoida) on an intertidal mudflat. Internationale Revue der gesamten Hydrobiologie und Hydrographie 55: 169-195.

BAYLY, I.A.E. 1970: Further studies on some saline lakes of south-east Australia. Australian Journal of Marine and Freshwater Research 21: 117-130.

BODIN, P. 1972a: Copépodes Harpacticoides marins des environs de La Rochelle. 3. Espèces de la zone intertidale de Fouras-Nord. Tethys 3: 841-863.

1972b: Copépodes Harpacticoides marins des environs de La Rochelle. 4. Espèces de la zone intertidale des Nauteries. Tethys 4: 651-682.

BOVÉE, F. de, COINEAU, N., SOYER, J. \& TRAVÉ, J. 1973: Sur l'existence d'une faunule interstitielle littorale dans 1'Archipel de Kerguelen (Terres Australes et Antarctiques françaises). Académie des sciences. Paris. Compte rendu hebdomadaire des sciences 276 : 1041-1044.

BOVÉE, F. de \& SOYER, J. 1974: Cycle annuel quantitatif du méiobenthos des vases terrigènes côtières. Distribution verticale. Vie et Milieu 24: 141-157.

CHAPMAN, G. 1955: Aspects of the fauna and flora of the Azores, 6 , The density of animal life in the coralline alga zone. Annals and Magazine of Natural History 12: $801-805$.

COULL, B.C. 1970: Shallow water meiobenthos of the Bermuda Platform. Oecologia (Berl.) 4: 325-357.

1972: Species diversity and faunal affinities of meiobenthic Copepoda in the deep sea. Marine Biology 14: $48-51$.

COULL, B.C. \& HERMAN, S.S. 1970: Zoogeography and parallel level-bottom communities of the meiobenthic Harpacticoida (Crustacea, Copepoda) of Bermuda. Oecologia (Berl.) 5: 392-399.

COULL, B.C. \& VERNBERG, W.B. 1975: Reproductive periodicity of meiobenthic copepods: Seasonal or continuous? Marine Biology 32: 289-293.

DINET, A. 1972: Étude écologique des variations quantitatives annuelles d'un peuplement de copepodes harpacticoides psammiques. Tethys 4: 95-112. 
FAVA, G. \& VOLKMANN, B. 1975: Tisbe (Copepoda: Harpacticoida) species from the Lagoon of Venice. 1. Seasonal

fluctuations and ecology. Marine Biology 30: 151-165.

GUILLE, A. \& SOYER, J. 1968: La faune benthique des substrats meubles de Banyuls-sur-Mer. Premières données qualitatives et quantitatives. Vie et Milieu 19: 323-360.

HAGERMAN, L. 1966: The macro- and microfauna associated with Fucus serratus $L$., with some ecological remarks. Ophelia $3: 1-43$.

HARRIS, R.P. 1972a: Seasonal changes in population density and vertical distribution of harpacticoid copepods on an intertidal sand beach. Journal of the Marine Biological Association of the United Kingdom 52: 493-505.

1972b: Reproductive activity of the interstitial copepods of a sandy beach. Journal of the Marine Biological Association of the United Kingdom 52: 507-524.

HEIP, C. 1971: The succession of benthic micrometazoans in a brackish water habitat. Biologisch Jaarboek Dodonaea 39: 191-196.

1973: Partitioning of a brackish water habitat by copepod species. Hydrobiologia 41: 189-198.

HICKS, G.R.F. 1971: Some littoral harpacticoid copepods including five new species, from Wellington, New Zealand. N.Z. Journal of Marine and Freshwater Research 5: 86-119.

(in press a): Ecological studies on marine algal-dwelling Copepoda (Harpacticoida). 1. Species composition and zoogeography; contribution to total seaweed meiofauna. N.Z. Journal of Marine and Freshwater Research.

(in press b): Ecological studies on marine algal-dwelling Copepoda (Harpacticoida). 3. Breeding activity. N.Z. Journal of Marine and Freshwater Research.

(in press c): Substrate preference of marine algal-dwelling Copepoda (Harpacticoida). Marine Biology.

HOPPER, B.E. \& MEYERS, S.P. 1967: Foliicolous marine nematodes on turtle grass Thalassia testudinum König, in Biscayne Bay, Florida. Bulletin of Marine science 17: 471-517.

HULINGS, N.C. 1974: A temporal study of Lebanese sand beach meiofauna. Cahiers de Biologie Marine 15: 319-335. 
HULINGS, N.C. \& GRAY, J.S. 1976: Physical factors controlling abundance of meiofauna on tidal and atidal beaches. Marine Biology 34: 77-83.

LASKER, R. , WELLS, J.B.J. \& MCINTYRE, A.D. 1970: Growth, reproduction, respiration and carbon utilization of the sand-dwelling harpacticoid copepod, Asellopsis intermedia. Journal of the Marine Biological Association of the United Kingdom 50 : 147-160.

MARCOTTE, B.M. \& COULL, B.C. 1974: Pollution, diversity and meiobenthic communities in the North Adriatic (Bay of Piran, Yugoslavia). Vie et Milieu 24: 281-300.

MCINTYRE, A.D. 1969: The ecology of marine meiobenthos. Biological Review 44: 245-290.

MCINTYRE, A.D. \& MURISON, D.J. 1973: The meiofauna of a flatfish nursery ground. Journal of the Marine Biological Association of the United Kingdom 53: 93-118.

MUKAI, H. 1971: The phytal animals on the thalli of Sargassum serratifolium in the Sargassum region, with reference to their seasonal fluctuations. Marine Biology 8: 170-182.

MUUS, B.J. 1967: The fauna of Danish estuaries and lagoons. Distribution and ecology of dominating species in the shallow reaches of the mesohaline zone. Meddelelser fra Danmarks Fiskeri-og Havundersogelser 5: $1-316$.

NOODT, W. 1957: Zur Ökologie der Harpacticoida (Crust. Cop.) des Eulitorals der deutschen Meeresküste und der angrenzenden Braçkgewässer. Zeitschrift für Morphologie und Ökologie der Tiere 46: 149-2 42 .

1971: Ecology of the Copepoda. In: "Proceedings of the First International Conference on Meiofauna," HULINGS, N.C. (Ed.). Smithsonian Contributions to Zoology, No. 76: 97-102.

OHM, G. 1964: Die Besiedlung der Fucus-zone der Kieler Bucht und der westlichen ostsee unter besonderer Berücksichtigung der Mikrofauna. Kieler Meeresforschungen 20: 30-64.

PALLARES, R.E. \& HALL, M.A. 1974a: Analisis bioestadisticoecologico de la fauna de copepodos asociados a los bosques de Macrocystis pyrifera. Physis (Buenos Aires) 33: 275-319.

1974b: Analisis bioestadisticoecologico de la fauna de copepodos asociados a los bosques de Macrocystis pyrifera. (Conclusion). Physis (Bueños Aires) 33: 409-432. 
PERKINS, E.J. 1974: "The Biology of Estuaries and Coastal Waters". Academic Press, London. 678pp.

POR, F.D. 1964: A study of the Levantine and Pontic Harpacticoida (Crustacea, Copepoda). Zoologische Verhandelingen 64: 1-128.

REMANE, A. 1952: Die Besiedelung des Sandbodens im Mẹere und die Bedeutung der Lebensformtypen fur die ökologie. Zoologischer Anzeiger 16: 327-359.

SANDERS, H.L. 1960: Benthic studies in Buzzards Bay. 3. The structure of the soft-bottom community. Limnology and Oceanography 5: 138-153.

SARMA, A.L.N. \& GANAPATI, P.N. 1972: Faunal associations of algae in the intertidal region of Visakhapatnam. Proceedings of the Indian National Science Academy 38: $380-396$.

SMIDT, E.L.B. 1951: Animal production in the Danish Waddensea. Meddelelser fra Danmarks Fiskeri-Og Havundersogelser 11: $1-151$.

SOYER, J. 1970: Bionomie benthique de plateau continental de la côte Catalane Française 3. Les peuplements de copépodes harpacticoides (Crustacea). Vie et Milieu 21: $337-511$.

1971: Bionomie benthique due plateau continental de la côte Catalane Française 5. Densités et biomasses du méiobenthos. Vie ẻt Milieu 22: 351-424.

STEPHENSON, W. 1972: The use of computers in classifying marine bottom communities. In: "Oceanography of the South Pacific," FRASER, R. (comp.). New Zealand National Commission for UNESCO: 463-473.

THORSON, G. 1957: Bottom communities (sublittoral or shallow shelf). In: "Treatise on Marine Ecology and Paleoecology," Vol. 1. HEDGPETH, J.W. (ed.). Memoir Geological Society of America 67: 461-534.

UHLIG, G., THIEL, H. \& GRAY, J.S. 1973: The quantitative separation of meiofauna: A comparison of methods. Helgoländer wissenschaftliche Meeresuntersuchungen 25: 173-195.

WARWICK, R.M. \& BUCHANAN, J.B. 1970: The meiofauna off the coast of Northumberland. 1. The structure of the nematode population. Journal of the Marine Biological Association of the United Kingdom 50: 129-146.

WIESER, W. 1960: Benthic studies in Buzzards Bay. 2. The meiofauna. Limnology and Oceanography 5: 121-137. 
PAPER 3

ECOLOGICAL STUDIES ON MARINE ALGAL-DWELLING COPEPODA (Fiarpacticoida). 3. BREEDING ACTIVITY.

pages: $131-188$ 
ECOLOGICAI, GTUDTES ON MARINE ALGA-DWELIING COPEPODA (HARPACMTCOIDA) 3. BREEDTMG ACTIVITY.

\section{GEOFEREY R.F. HICKS}

Zoology Department, Victoria University of Wellingion, Private Bag, Wellington, New Zealand.

\section{ABSTRACT}

The reproductive status of twenty algal-dwelling harpacticojd copepods at Island Bay, wellington, New Zealand was investigated from April 1973 to March 1974. These data are the First published account of the breeding regime in natural populations of truly phytal species.

In most species the breeding season, as defined by the presence of ovigerous fenales in the population, was eithex continuous or protracted. Distinct maxima occurred at different: times in different species but a large number (40\%) reached maximum breeding activity in autumn. The number of copepodites in the population rather than the proportion of ovigerous females is suggested as a more important criterion with regard to the effects that reproductive activity has on population structure and density. The relationship between the number of eggs per female and the proportion of ovigerous females in the population is discussed as it relates to the reproductive capacity and the timing of maximum breeding activity. There was little apparent correlation with environmental temperature and food supply and continuous breeding is perhaps related to the small sumex-vinter seawater temperature differential experienced in the cook strait region, and the suspected 
unlimited avajlability of food. Sex ratios varied noticeably interspecifically and intraspecifically from season to season. Tt is suggested that in most species such variations are the result of a homeostatic mechanism operating relative to the population density. Females preoominate during periods of low pooulation density while males predominate during periods of high abundance.

A temporal separation with regard to the maximum reproductive activity is indicated for the most abundant species occurring on Coraliina. Such reproductive succession may reduce competition between coexisting species.

Data are presented on the life history of the strictly phytal species porcellidium dilatatum (Porcellidiidae). Longevity and egg maturation rates compare favourably with those of level-bottom meiobenthic species. In general, total reproductive capacity is higher in algal-dwelling harpacticoids than in the more extensively researched interstitial benthic species.

\section{INTRODUCTION}

Iiterature on the reproduction of harpacticoid copepods has until recently been concerned mainly with the experimental approach to rearing and Jarval development (Nicholis 1935, Frazer 1936, Johnson \& Olson 1948, Bozic 1960, Bresciani 1960, Barnett 1966, Vilela 1969, Itô 1970, 1971, Huizinga 197.̌, Takano 1971a, b, Betouhim-El \& Kahan 1972, Rosenfield \& Coul1 1974, Smol \& Heip 1974), and to genetical experimentation with their offspring (Volkmann-Rocco \& Fava 1969, Volkmann-Rocco is Battaglia 1972, and Battaglia \& Volkmann-Rocco 1973), whie 
Weip (1972) has criculated the therthote rate of natural increase (reproductive potontio) from field data of tie sand.. dwelling species Camue la derplexa r. \& A. Scott, Tachidns discipes Giesbrecht and Paronychocamotus nanus (Sers).

Few fielä studies have been carried out on the seasonal pattern of reproductive activity. Barnett (1970) presented a detailed account of the life cycles of two mud-flat drelling species of Platychelipus (Laophontidae) and Lasker et al. (1970) analysed the growth, reproduction and metabolism of the meioepibenthic sand-dwelling species Asellopsis intermedia (T. Scott). The reproduction and growth of Bulbamphiascus imus (Brady) and the seasonal reproductive cycle of Halectinosoma herdmani (T. \& A. Scott) have been described from the fine sand biotope of Marseille by Dinet (1972), while Heip (1973) and Coull \& Vemberg (1975) have noted the successional effects of breeding in some brackish water and estuarine species. Harris (1972) has presented what is probably the most comprehensive analysis of the seasonal changes in reproductive activity based on ten interstitial species from a sandy beach in cornwall. In a long term study of the meiofauna of Firemore Bay (Loch Ewe, Scotland), McIntyre \& Murison (1973) briefly redescribe the breeding cycles of four of the species inciuded by Harris, and only minor differences in breeding maxima between the two sites are indicated.

In all these studies distinct periods of reproductive activity were observed, with nost species bxeeding at their maxinum in the late borcal spring and summer, while rnany of the semi-estuarine species observed by Bodin (1972a, b, c) were believed to breed eithex throughout the year, as did Paxonychocamptus narus (Sars) (tefp 1973), or have breeding maxima in the whing and ande. 
In the courso of m erologtod study on the harpacticota copepods of the nawne algai biotope at Island Bay, wellington, pronounced censona. changes in population density were observea on all ot the aedreeds studied. In order to help explain such variability. Guantitative data on the reproductive state of the mosi: aburdant spectes were obtained. Infornation on the population stzucture was collected and analysed for seasonal. breeding activity of twenty species.

This therefore is the first study to be published on the reproductive activity of truly algal-dwelling harpacticoids and is the first of its type in the southern hemisphere. It must be stressed that the present data cover twelve months only and are applicable only to the site studied and to the year of the study. The composition of the present fauna, its occurrence, spedies associations and seasonal variability in population density has been described elsewhere (Hicks in press a, b) .

\section{METHODS}

Hicks (in press a) has given a detailed account of the study area, physical variation in the environment, seaweed habitats and the sampling methods used. Seaweed samples were collectea within the last week of each month from April 1973 to March 1974. Sublitioral samples were obtained by SCUBA-diving with a portable samplermcutter measuring $10 \mathrm{~cm} \times 10 \mathrm{~cm}$.

Copepods were narcotized in the laboratory with an isotonic solution of MgCl and then fixed in 10\% formalin. Those from sublittoral algae vere hand sorted while specimens from intertidal pool Corallina officinalis were collected by the swirlingdecantation method see milig et al. 1973). Hand sorting was compleced under a binocular nicroscope and the extracted samples 
were stored in a $2: 1$ mixture of $5 \%$ fomalin and $50 \%$ mono-etyyem glycol. Mean number of copepods extracted from tho sedved.. were normally calculated from two samples, but sonetimed thous were used.

The mean, variance and standard deviation were sach calculated from pooled sample data to indicate the degroe of sampling error for quantitative values. Analyses rovealed a S.D. of about $5 \%$ and most changes in data presented in the results are therefore considered meaningful. The collection efficiency of the sorting procedures was tested and estimated at over 90\% (Hicks in press a). Open circles occurring on accompanying figures symbolize data based on less than ten individuals.

Adults and copepodites were collected but many of the nauplii were not retained on the $0.1 \mathrm{~mm}$ sieve used. Furthermore, their identification is difficult and for these reasons navi i were not included in the analysis. Copepodites were comined as a group, without separation into stages; adults were easily sexed in the present species, the males being distingujshed by their modified haplocer or sub-chirocerate antennules and for by the reduced fifth leg. The number of females carrying ovisacs and the number of eggs in each sac were counted. It was possible to assess the number of mating pairs (males grasping females) in five species. The extraction technique however, especially from the Corallina samples, probably reduced estimates of numbers of mating pairs because of the vigorous swirling and decantation process. Individualss previously cbserved to be coupled often disengaged on the adation of preservative and only those species with tenacious coupling remained intact; therefore the copular data are minimum values. 
To gain a representatiro col section ot data on the mean number of eggs per female a subsurplag tochnigue was employed (Motoda - see Wiborg 1961). In most wases the estimation was based on over 30 individuals. Hotal length measurements have been made from the antertior edge of the rostrun to the posterior border of the caudal rami.

\section{RESUTIS}

Most species studied apparentiy breed continuously throughout the year, with distinct maxima of breeding activity occurring at different times (Table $1 ;$ Figs $1-5,8-21$ ). The following results describe the proportion of females carrying ovisacs expressed as the percentage of the total female population; number of eggs pex female; percentage of copepodites per total population; sex ratio as well as total population density. Where applicable the pexcentage of mating couples is also included. Reproductive capacities are derived by multiplying the mean number of eggs per female by the mean annual percentage of ovigerous females. In order to allow comparative statistical estimates of breeding potential between species, it has been necessary to assume that the females produce one brood annualy, although evidence does suggest that this may not always be the case.

\section{BREEDING ACTIVITY}

Ectinosoma australe Brady (Fig. i) .

Adult females carrying eggs were present in all months except May 1973 when no $\mathbb{E}$. austrele were present in the samples. A peak of ovigerous females was observed in April with a further 
FIG. 1 - Seasonal breeding pattern of Ectinosoma austraje on the alga Corallina officinalis. Open circles represent data from less than ten individuals, while broken lines indicate zero presence in the population. 


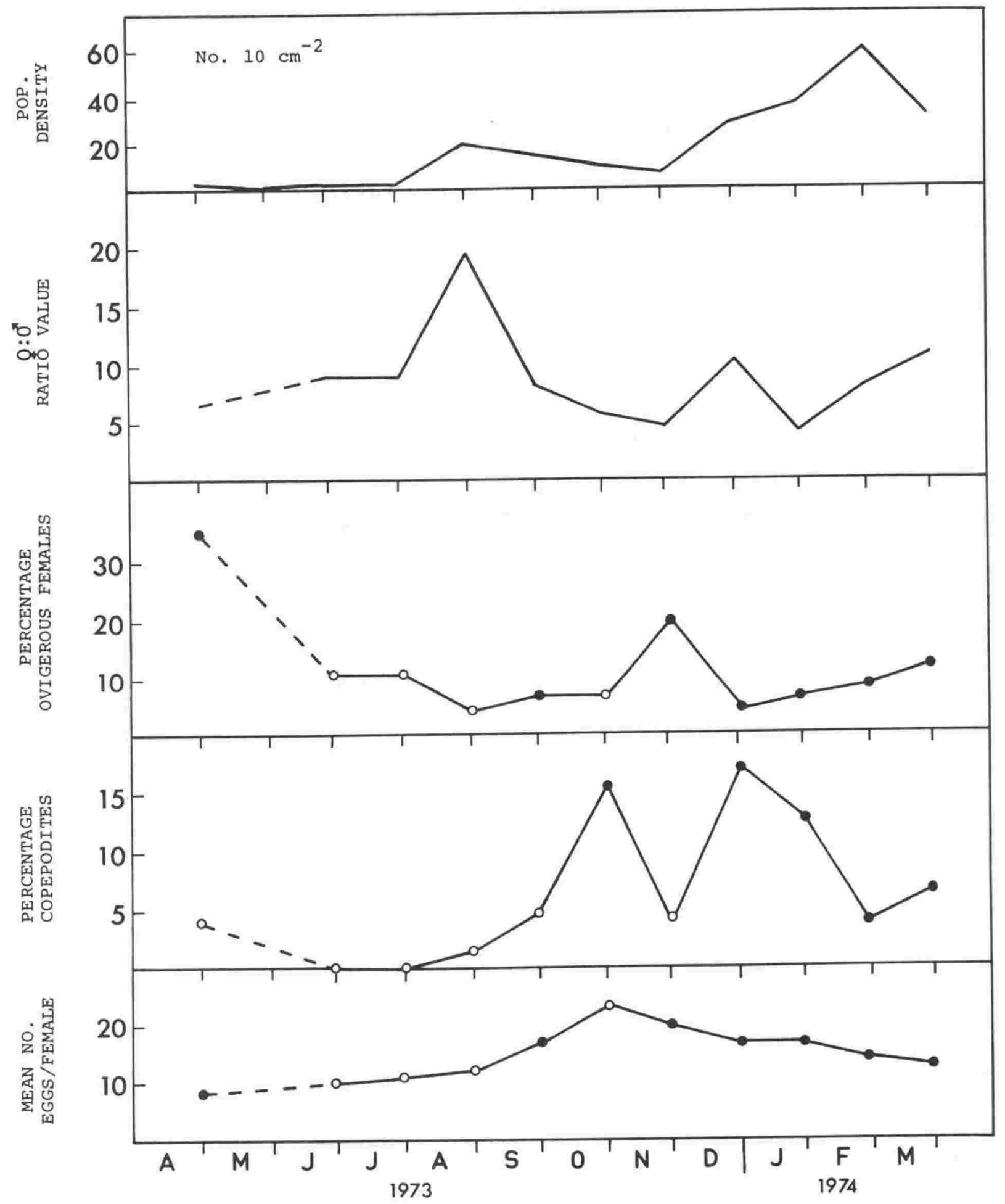


TABIE 1 - Annual mean ercontage of ovigerous females, annual mean number ot egss carried by ovigerous fenales and reproductive capacities. Figures are calculated for a 11 copepods exarnined between April 1973 and March 137\%. Eigures in parentheses indicate the sample size (n).

Species

Mean : Mean No. Reproductive Ovigerous of Eggs/o Capacity

\begin{tabular}{|c|c|c|c|c|c|}
\hline$\underline{\text { E. australe }}$ & 11.93 & (151) & 15.12 & (98) & 180.4 \\
\hline H. pulvinatus & 24.61 & $(68)$ & 24.69 & $(48)$ & 607.6 \\
\hline Z. mirabilis & 19.47 & $(140)$ & 22.86 & $(48)$ & 445.1 \\
\hline T. holothuriae & 14.27 & $(124)$ & 18.89 & $(104)$ & 269.6 \\
\hline s. spinatum & 30.48 & $(218)$ & 37.56 & $(67)$ & 1144.8 \\
\hline P. dilatatum & 66.45 & $(1312)$ & 13.25 & $(276)$ & 880.5 \\
\hline P. erythrum & 57.03 & $(201)$ & 6.86 & $(48)$ & 391.2 \\
\hline A. littoralis & 78.01 & $(625)$ & 7.80 & $(191)$ & 608.5 \\
\hline E. regalis & 73.84 & $(632)$ & 8.02 & $(275)$ & 592.2 \\
\hline N. pectinipes & 60.26 & $(254)$ & 50.09 & $(109)$ & 3018.4 \\
\hline P. brevicornis & 12.20 & $(50)$ & 25.32 & (33) & 308.9 \\
\hline A. cinctus & 39.04 & $(56)$ & 18.91 & $(45)$ & 738.2 \\
\hline A. perturbata & 31.83 & $(739)$ & 45.35 & $(140)$ & 1443.5 \\
\hline R. propinqua & 31.94 & $(120)$ & 16.62 & (63) & 530.8 \\
\hline M. flava & 32.63 & (195) & 10.13 & $(1.41)$ & 330.5 \\
\hline O. Iinearis & 28.22 & $(365)$ & 22.15 & $(187)$ & 625.1 \\
\hline I. cornuta & 35.54 & $(16)$ & 15.45 & (14) & 549.1 \\
\hline L. c. nigrocincta & 36.31 & $(140)$ & 14.89 & $(86)$ & 540.7 \\
\hline P. Ineinerti & 29.70 & $(475)$ & 23.51 & $(127)$ & 698.2 \\
\hline L. armata & 42.06 & $(40)$ & 15.58 & $(35)$ & 655.3 \\
\hline
\end{tabular}


smaller peak in vovomos. The mean annual percentage of ovigerous females, horever, was the lovest of any species with only $11.93 \%$, with the April maximum reaching $35.0 \%$. The number of eggs carried by females in the single ovisac rangea from 9 to $32(\bar{x}=15.12, n=98 ;$ Table 1$)$. In October the mean number of eggs per female increased to a maximum of $23.67(n=3)$. Copepodites were found in peak numbers in October and Decerber. Adult females greatly outnumber adult males, the overall ratio for adult females:adult males being 7.74:1. Females are proportionally at their greatest numbers in August, December and March.

Harpacticus pulvinatus Brady (Fig. 2).

Breeding in this species takes place during the whole year and reaches an apparent maximum in July. Since the actual numbers of ovigerous females present in the samples was small, little significance can be attached to the observed nonth to month variability. In $\mathrm{H}$. pulvinatus the number of eggs carried in the single egg sac varied from 16 to $46(\bar{x}=24.69, \mathrm{n}=48)$, with a peak in November, but sample numbers were small. Copepodites also occurred throughout the year with three distinct peaks evident.

Mating pairs were found in May, August and from october to March, with most occurring in November. The number of mating pairs found was never great and the number of individuals mating did not exceed $9.30 \%$ of the total population in November.

The sex ratio showed an anmual predominance of females $(1.83: 1)$, with a revexsal occurring in June and November. 
340

FIG. 2 - Seasonal breeding pattern of Harpacticus pulvinatus on the alga Pterocladia lucida. open circles represent data from less than ten individuals, while broken lines indicate zero presence in the population. 


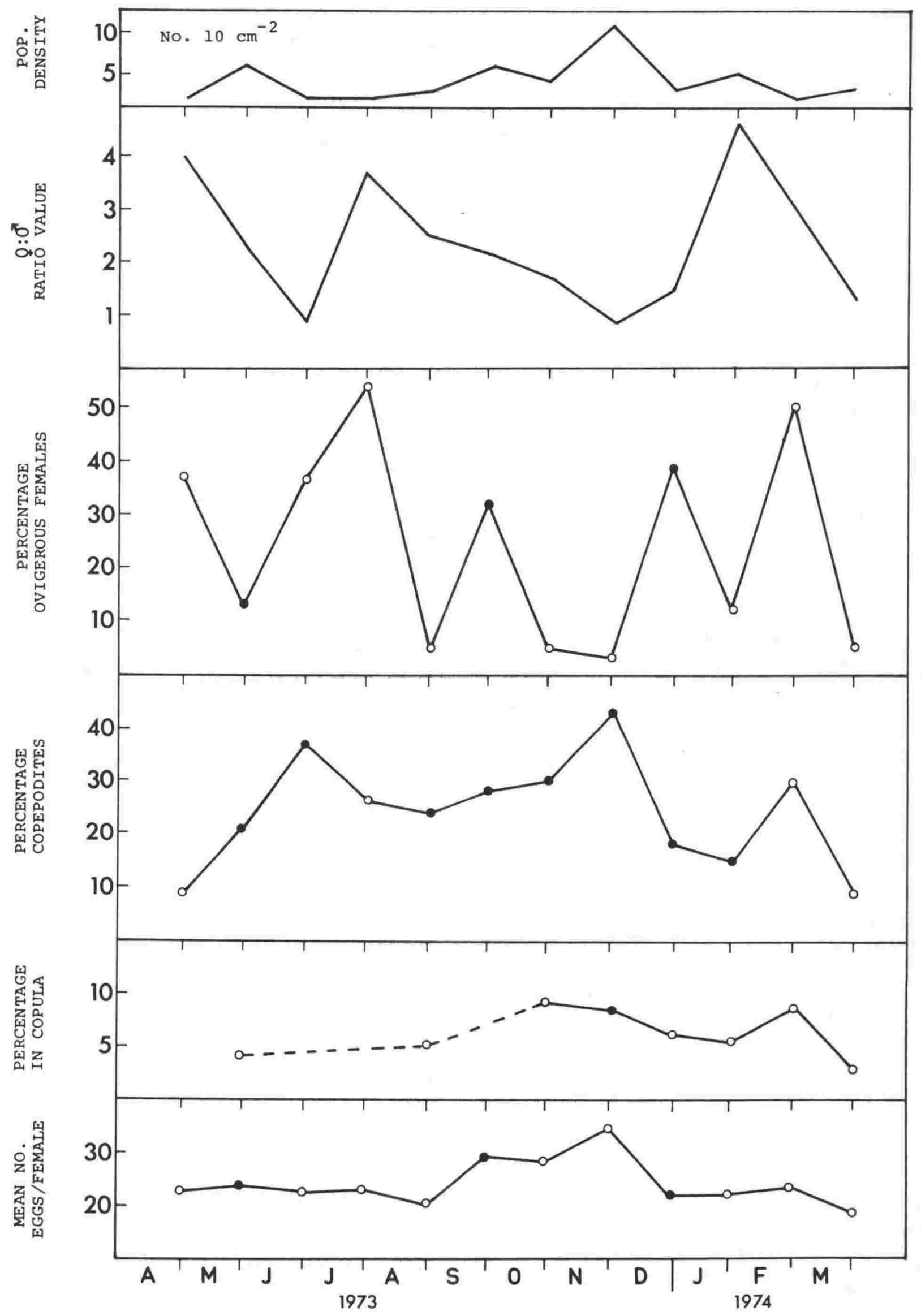


Zausopsis mirabilis Lang (Tig. 3) .

Breeding females were present in ali nonths except. June, with three periods of peak activity in April, July and December. Ovigerous females were at their most numerous in December (68.89\%) but throughout the rest of the year they represent less than $50 \%$ of the adult female population. There is a single egg sac which contained between 9 and 36 eggs with an annual mean of $22.86(n=43)$. Copepodite maxima occurred in May, July, October and February.

Mating couples reached their highest level (7.26\%) in November, shortly after the spring peak of copepodites. Females greatly outnumbered males in the population (5.94:1) over the entire year.

Tisbe holothuriae Hures (Fig. 4).

Ovigerous females were found in alternate months until December when a rise to an autumnal. (March) maximum of egg production is observed (33.33\%). The mean annual percentage of females carrying eggs was low $(14.27 \%, n=124)$. The mean number of eggs in the single egg sac was 18.89 ( $\mathrm{n}=104)$ with a range from 5 to 48 . Insufficient numbers of ovigerous females throughout the winter and spring did not allow trends in egg numbers to be detected. Copepodite numbers rose to their maximum (51.72\%) in July with a further rise (data incomplete through loss of Novemier sample) apparent from the October samples.

T. holothuriae males dominated the population and amounted to $46.97 \%$ of the total in all samples. The mean annual sex ratio of females:males is $0.66: 1$ with females dominating only in September $(41.67 \%)$. 
142.

PIG. 3 - Seasonal breeding pattern of Zausopsis Inixabilis on the alga Zonaria turneriana. Open circles represent data frrom less than ten individuals, while broken lines indicate zero presence in the population. 


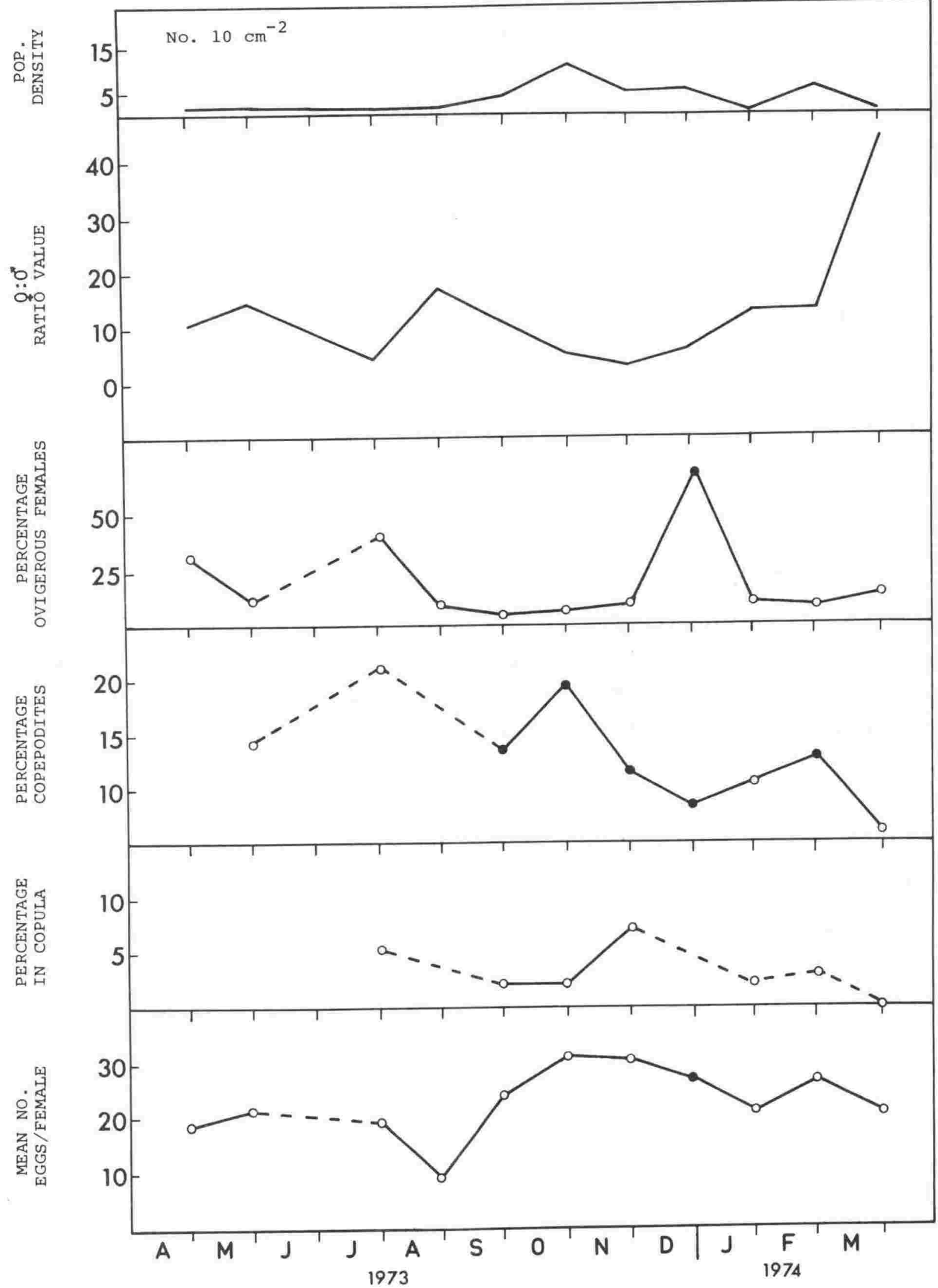


FIG. 4 - Seasonal breeding pattern of Tisbe holothuriae on the alga Enteromorpha intestinalis. Open circles represent data from less than ten individuals, while broken lines indicate zero presence in the population. The November sample is not represented. 


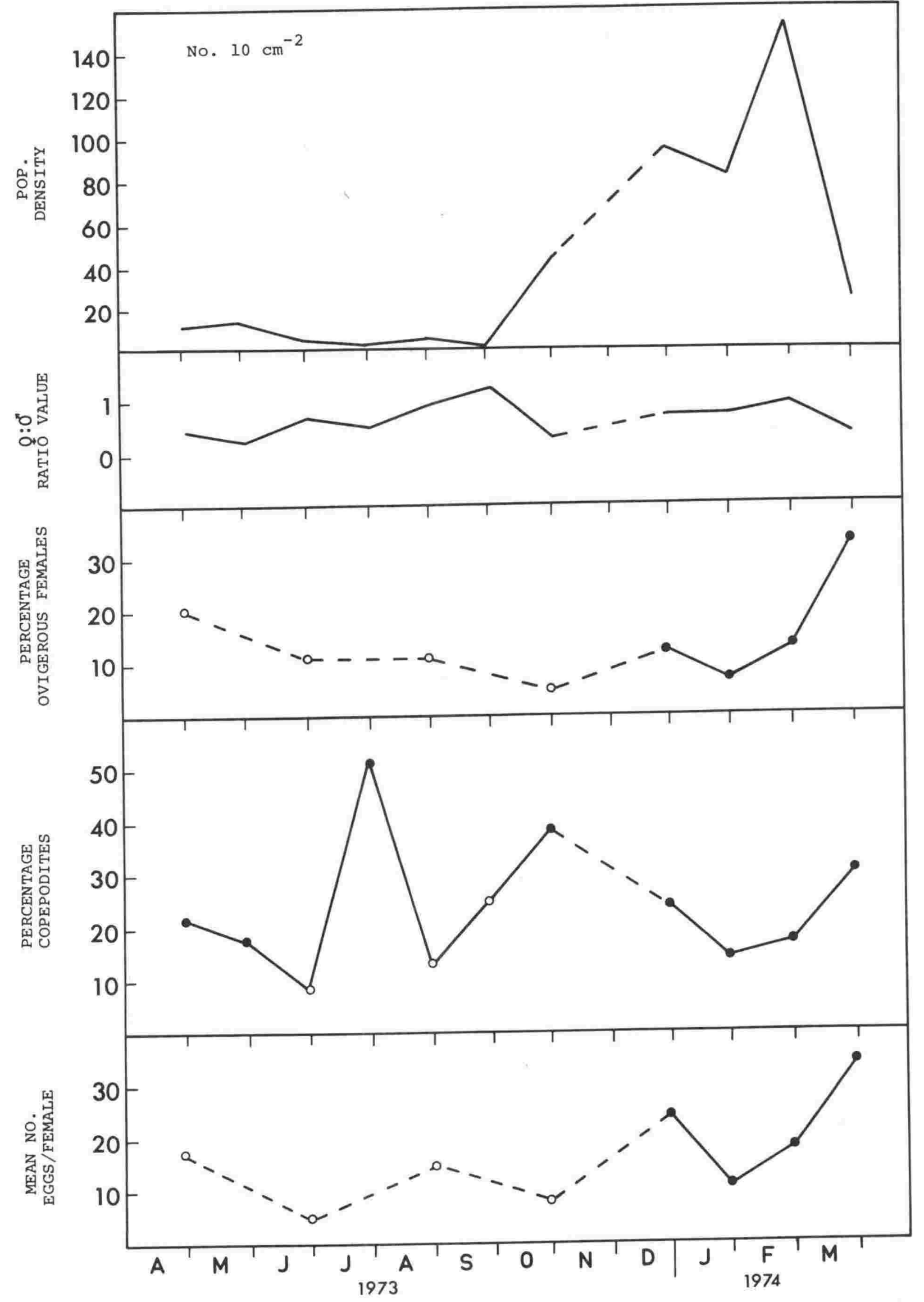


Scutellidium spinatum Hicks (Fig. 5).

There was no clear period of maximum breeding in $\underline{\mathrm{s}}$ spinatum as there are winter, summer and autumnal rises in numbers of ovigerous females. No females were found carrying egg sacs during May, November and January. The mean annual percentage of egg bearing females was $30.48 \%(n=218)$. The number of eggs in the single ovisac ranged from 25 to 51 $(\bar{x}=37.56, n=67$, Table 1$)$, with the greatest number in August. Copepodites rose to a summer maximum of $76.92 \%$. Females were just over twice as numerous as males (2.03:1), and were predominant in all months except January. Porcellidium dilatatum Hicks (Fig. 6).

Continuous breeding was clearly evident in this species, with three distinct peaks of breeding activity superimposed on this pattern. The percentage of females carrying eggs never fell below $43 \%$, while there appeared to be three peaks of production in september, December and April. This species had the highest mean percentage of ovigerous females, other than Alteutha littoralis and Eupelte regalis, with a mean annual 65. 45\% (Table 1). A seasonal trend is observed in the number of eggs in the single egg sac of $\underline{P}$. dilatatum, with a maximum of $18.43(n=40)$ occurring in December, decreasing to 9.71 $(n=38)$ in July. The range in numbers of eggs per sac is from 6 to $23(\ddot{x}=13.25, n=276$, Table 1). The september and December breeding maxima contributed to the peak of copepodites found in December $(52.62 \%)$.

P. Ailatatum revealed a mean annual percentage in copula of $i 6.17 \%(n=966)$ and is the highest for any species studied, and probably relates to the rather tenacious coupling behaviour of this species. Most mating couples were found in May, 
FIG. 5 - Seasonal breeding pattern of Scutellidium spinatum on the alga Corallina officinalis. Open circles represent data from less than ten individuals, while broken lines indicate zero presence in the population. 


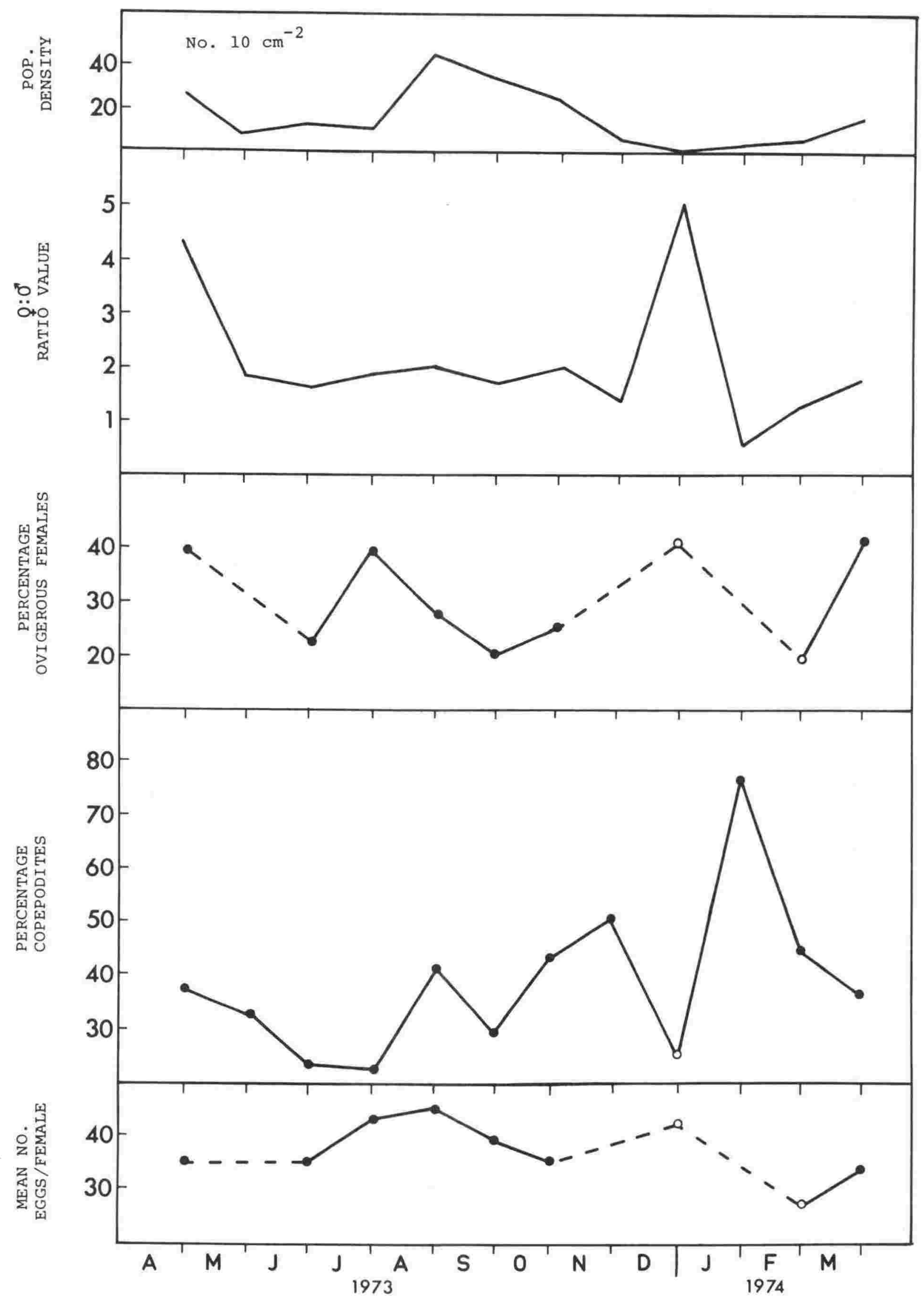


146.

FIG. 6 - Seasonal breeding pattern of Porcellidium dilatatum on the alga Zonaria turneriana. Open circle represents data from less than ten individuals. 


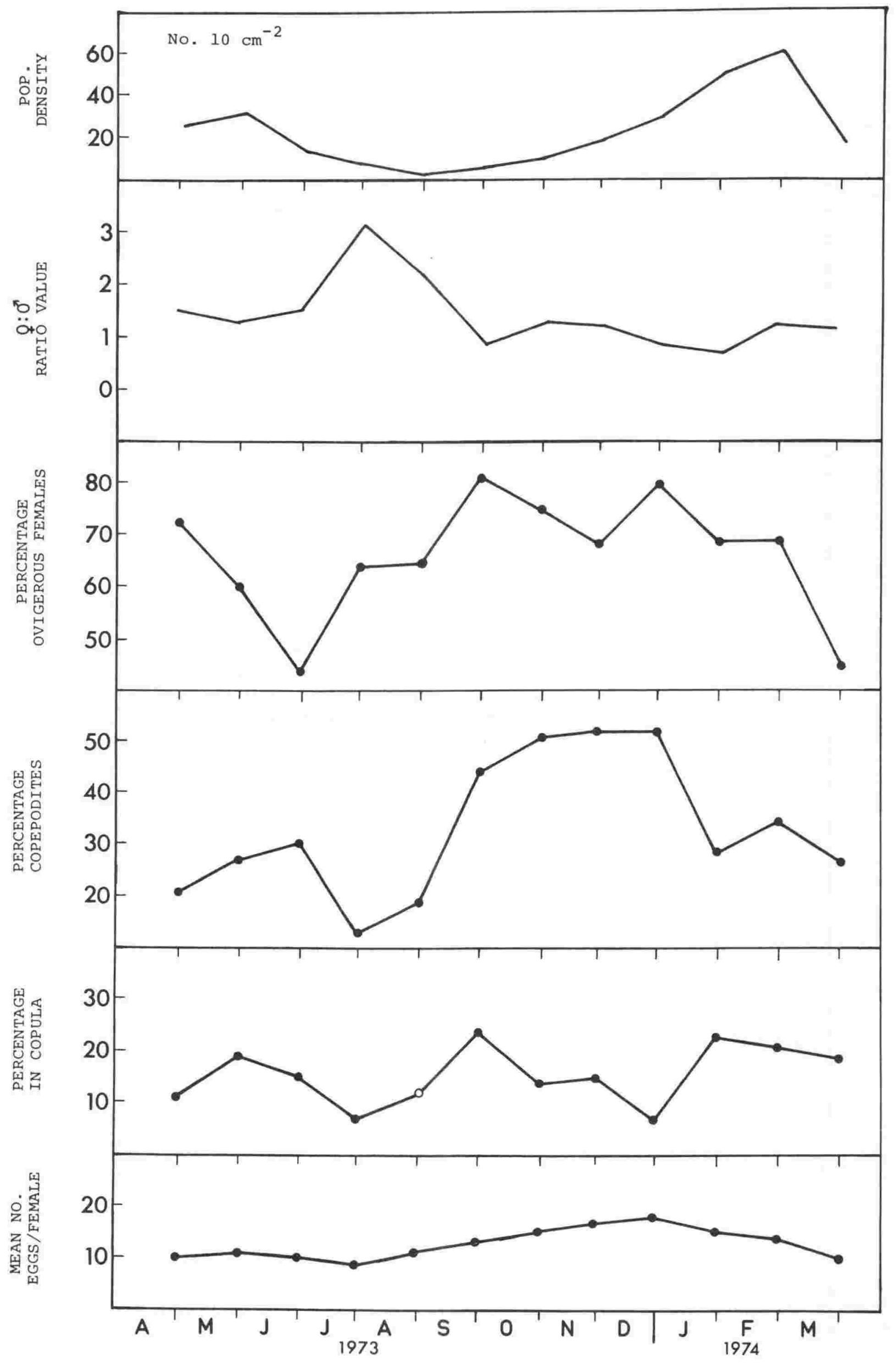


147 .

FIG. 7 - Percentage occurrence of males in the population of a). P. dilatatum and b). A. cinctus from the algae zonaria and Corallina respectively. Open symbols represent the maximum period of ovigerous females in the population, whils the solid symbols represent the period of maximum occurrence of copepodites in the population. 

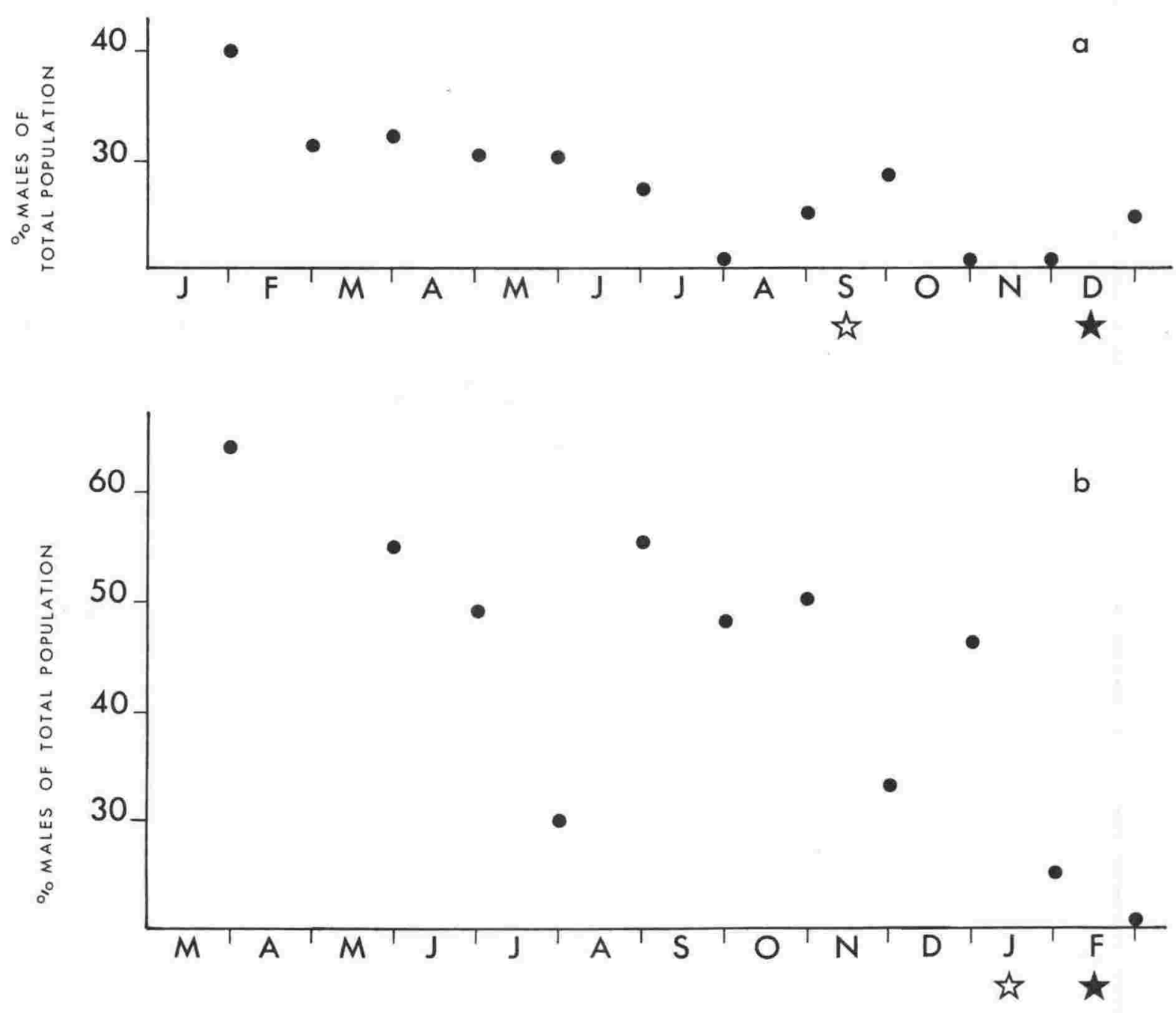
September and January.

Throughout the year there was a higher number of females than males (1.19:I). Reversals of this ratio occurred in September, December and January. Males were at their minimum in November and rose to their greatest abundance in January, after which they gradually declined at a nearly constant rate (Fig. 7). The greatest percentage of males was recorded during periods of high population density (April, May, January, March). Porcellidium erythrum Hicks (Fig. 8).

The complex nature of the seasonal population density of

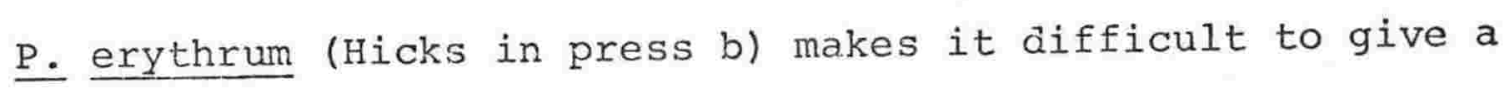
detailed account of the reproductive cycle. Ovigerous females appear in the population irregularly. Mean annual percentage of females carrying eggs was $57.03 \%(n=201)$.

rhe annual sex ratio was 1.26:1 in favour of the females, with males preotominating in July and January, while the range of eggs per egg sac was 3 to $11(\bar{x}=6.86, n=48)$, the lowest of all the species studied (Table 1 ).

\section{Alteutha littoralis Pallares (Fig. 9).}

This species had the highest mean percentage of ovigerous females in the population of any other species in this study. The mean annul percentage of females carrying eggs was $78.01 \%$ $(n=625)$ and it reached a maximum in september where $88.55 \%$ of all adult females were carrying eggs. The minimal level was in May where still $69.35 \%$ of the females were ovigerous. No clear peak of spawning was evident, but rather a high level of continuous egg production throughout the year. Number of eggs pex ovisac suggested a seasonal trend with a range from 6.08 in Nay to 9.37 in September $(\bar{x}=7.80, n=191$, Table 1$)$ and the numbers nere low compared to other species. Copepodites reached a maximum in February (14.638). 
FIG. 8 - Seasonal breeding pattern of porcellidium erythrum on the alga Xiphophora chondrophylla. Open circles represent data from less than ten individuals, while broken lines indicate zero presence in the population. 


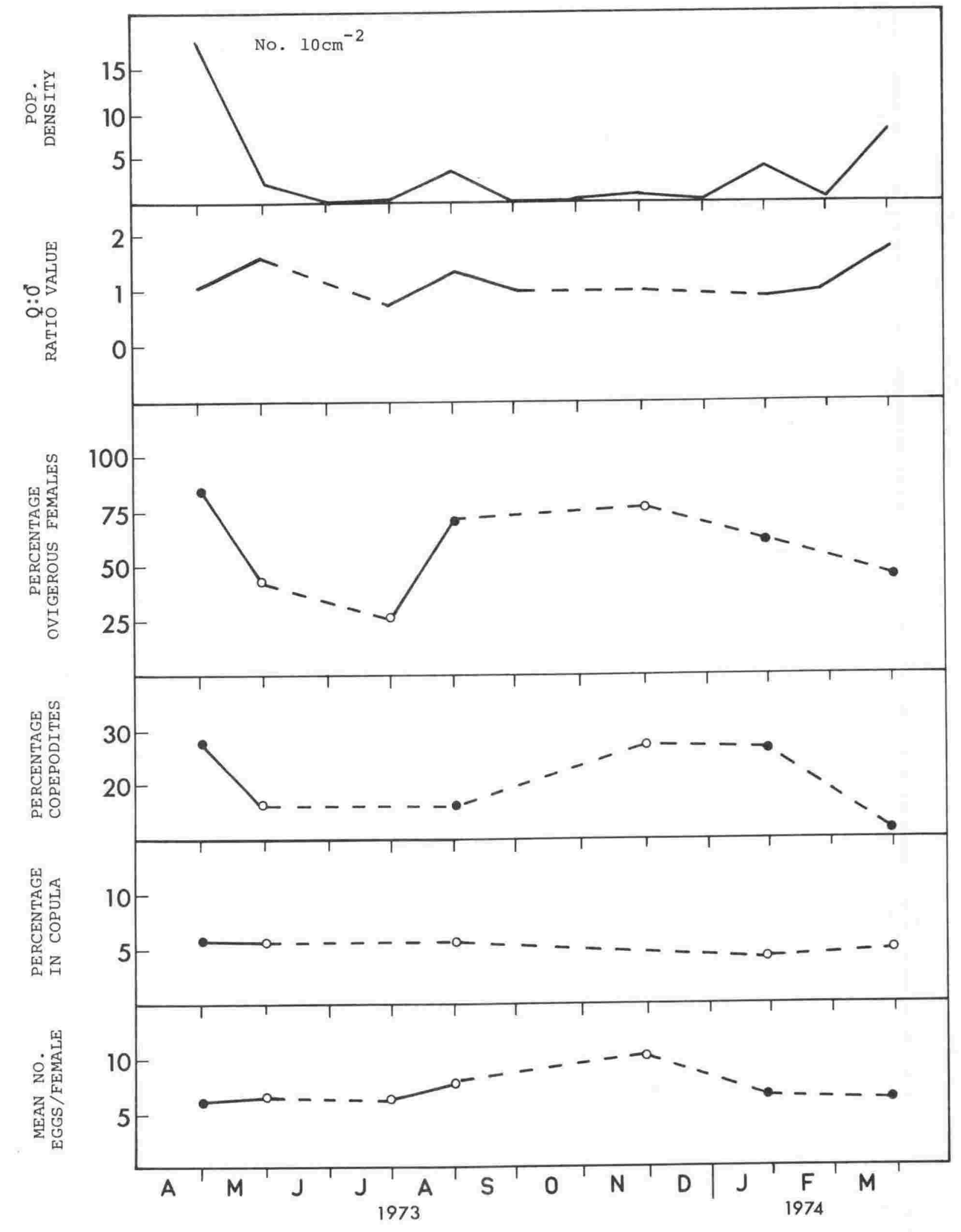


150.

FIG. 9 - Seasonal breeding pattern of Alteutha littoralis on the alga pterocladia lucida. Open circles represent data from less than ten individuals. 


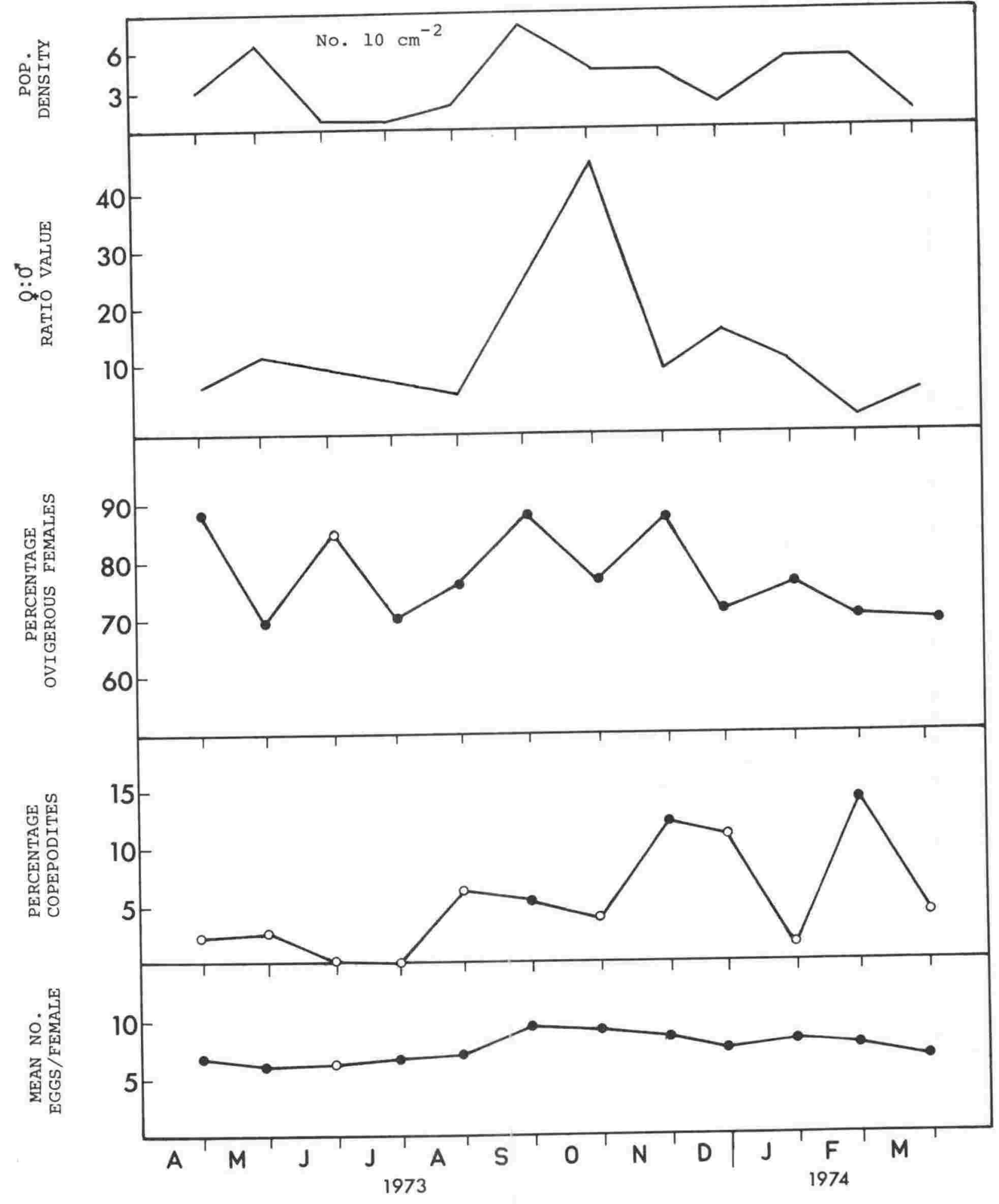


The male population was highest in February (19.51\%), but the distribution of sexes was greatly in favour of the females with a ratio of $11.46: 1$ and represented the species with the highest female complement $(91.98 \%)$ in the total population.

Eupelte regalis Hicks (Fig. 10).

Egg production in E. regalis was continuous. In autumn the percentage of ovigerous females was at its highest with $90.00 \%$ in April, after which it declined to its lowest level of $50.00 \%$ in october. Females with eggs increased progressively during the summer while the mean annual percentage females with eggs amounted to $73.84 \%(n=632)$. In this respect $\underline{E}$. regalis ranks second to A. littoralis in level cf ovigerous females in the population. The single egg sac carried by this species contained from 4 to 15 eggs $(\bar{x}=8.02, n=275$, Table 1$)$ which is low compared to many other species. There was little seasonal variation in the mean numbers of eggs per female which ranged from 6.31 in November to $9.32 \mathrm{in}$ January, indicating a slight increase over the summer months. The percentage abundance of copepodites increased to reach their maximum level in september $(51.70 \%)$.

The adult male population declined progressively after the April maximum of ovigerous females. Females outnumbered males with an annual mean sex ratio of $3.30: 1$.

Neopeltopsis pectinipes Hicks (Fig. 11).

N. pectinipes reached its maximum level of breeding in autumn, although the percentage of ovigerous females in the population at no time fell below 25\%. More eggs were carried in their single egg sac than in any other species $(\bar{x}=50.09$, $\mathrm{n}=109$, Table 1). The individual range was between 21 and 92 per ovisac. A seasonal pattern in eggs per female was indicated 
FIG. 10 - Seasonal breeding pattern of Eupelte regalis on the alga Corallina officinalis. Open circle represents data from less than ten inđividuals. 


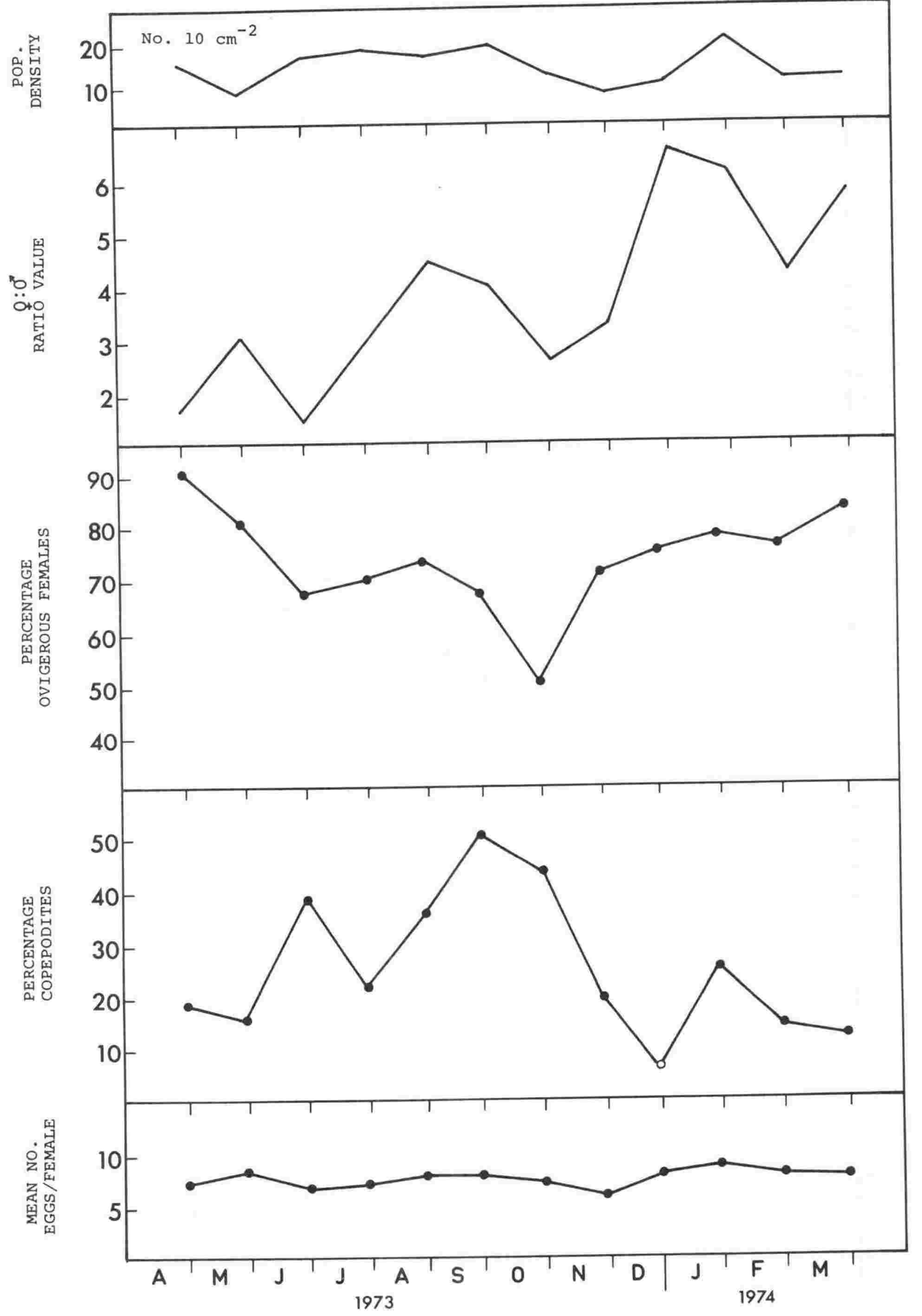


153,

FIG. Il - Seasonal breeding pattern of Neopeltopsis pectinipes on the alga pterocladia lucida. Open circles represent data from less than ten individuals. 


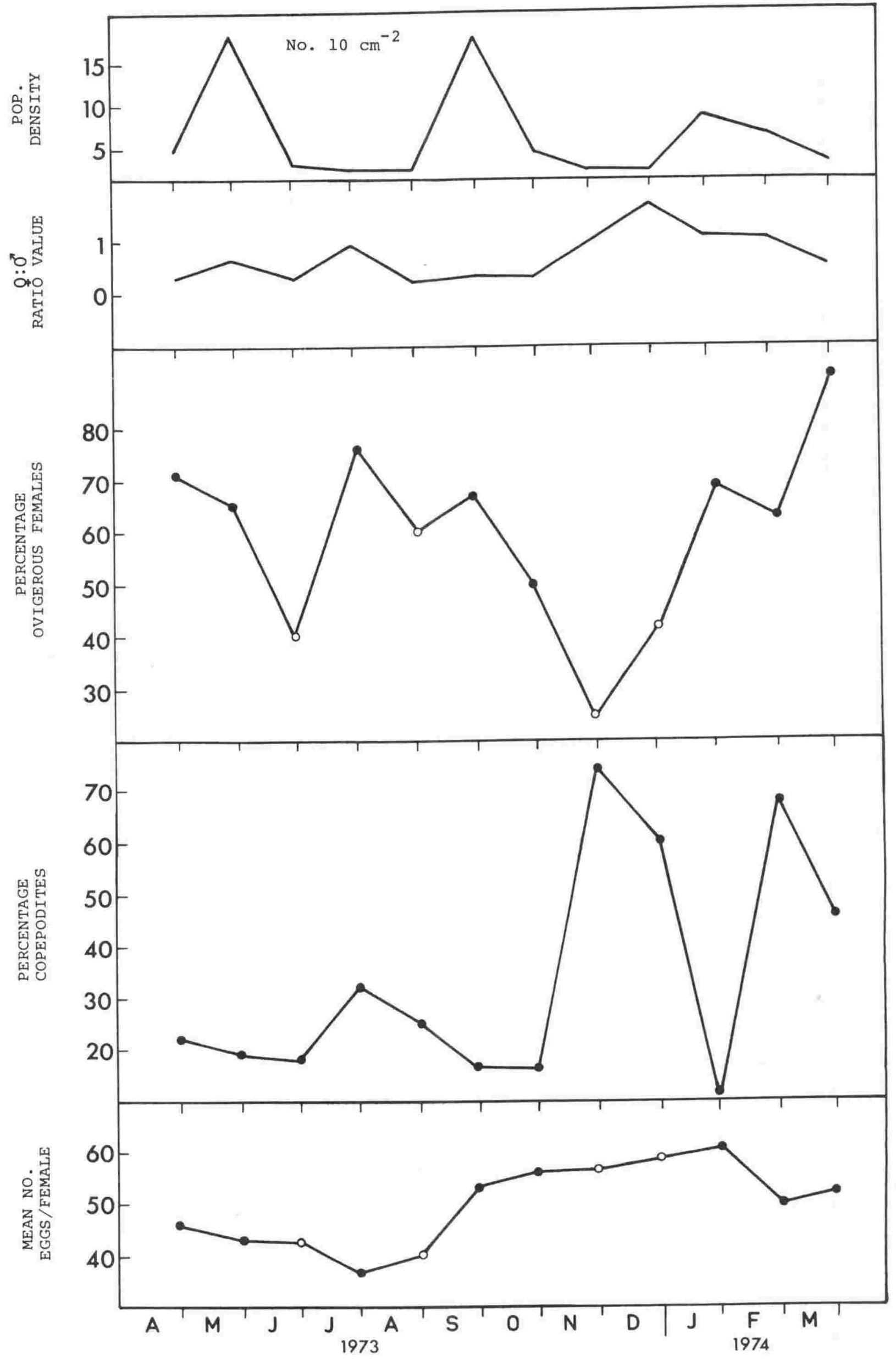


by an increase from the winter low of $37.20(n=10)$ through spring to the summer maximum of $61.78(\mathrm{n}=32)$ in January. Copepodites reached peak numbers in July, November and February. The November maximum was $74.19 \%$

Males outnumbered females; the overall ratio of adult females to adult males was $0.55: 1$, but during the summer (December, January, February) the females predominate. The onset of this change was observed by way of a $1: 1$ ratio which existed in November.

Paradactylopodia brevicornis (Claus) (Fig. 12).

p. brevicornis reached its maximum spawning period in autumn ( $41.18 \%$ ), and females with egg sacs were absent from the population in May and February. Other than E. australe, this species had the lowest annual mean level of ovigerous females of all species included in this study $(\bar{x}=12.20 \%, \mathrm{n}=50)$. The number of eggs per female showed a high point in late winter (33.0), but is based on a single ovigerous female. Little can be deduced from these data as the sample sizes were too small. Copepodites reached four peaks, but the maximum of $34.25 \%$ of the total population was observed in August.

The sex ratio favoured the females by an annual mean of $1.94: 1$.

Amphiascopsis cinctus (Claus) (Fig. 13).

The reproductive season of $\underline{A}$. cinctus lasted 10 months with a maximum percentage of ovigerous females (83.00\%) in January. This peak was followed by a rapid decline in March to zero in April. Ovigerous females reappeared in June and the proportion rose sharply from August to January. There are two egg sacs in $\underline{A}$. cinctus with a mean annual number of 
155.

FIG. 12 - Seasonal breeding pattern of paradactylopodia brevicornis on the alga Corallina officinalis. Open circles represent data from less than ten individuals, while broken lines indicate zero presence in the population. 


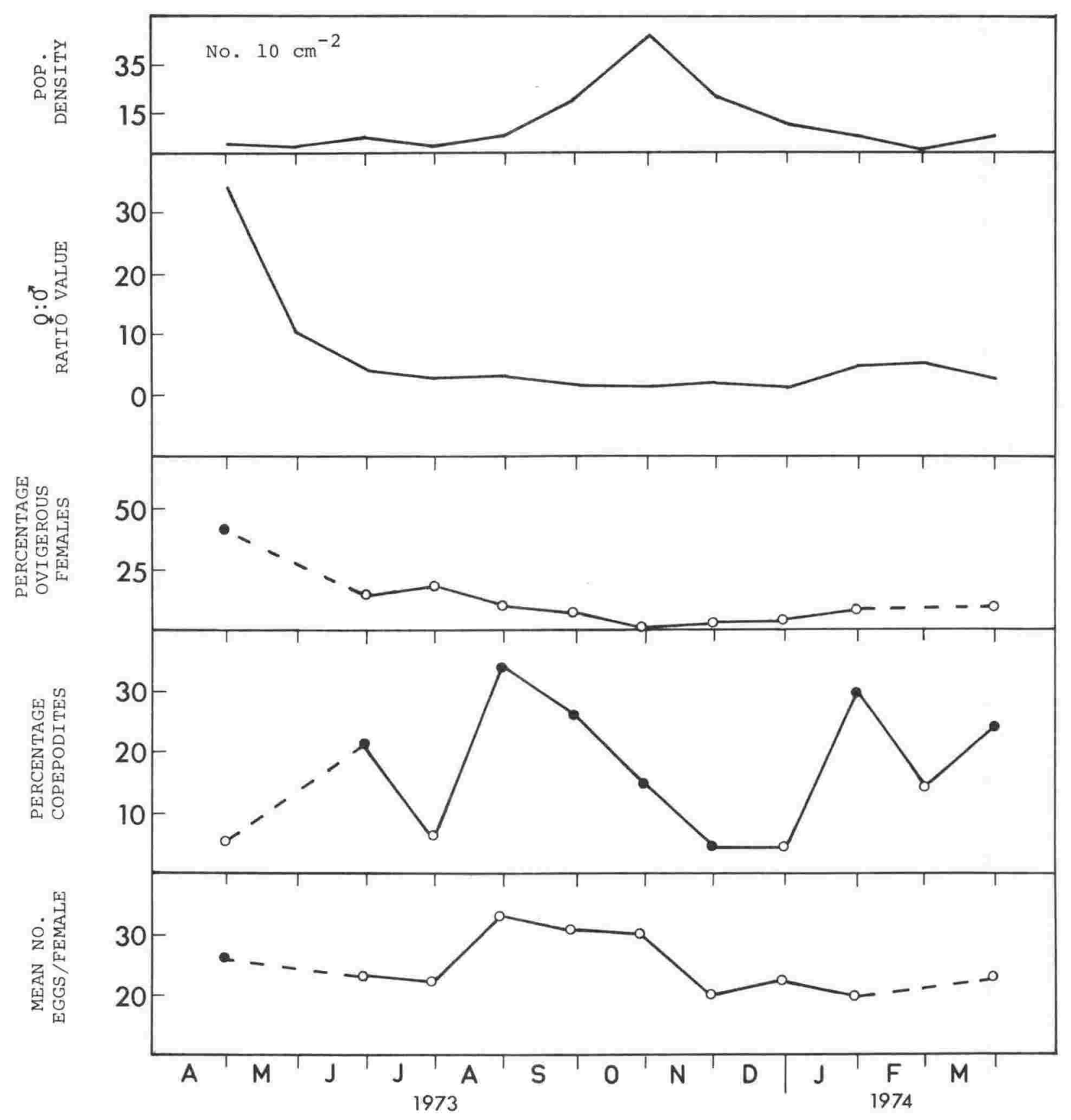


156.

FIG. 13 - Seasonal breeding pattern of Amphiascopsis cinctus on the alga Corallina officinalis. open circles represent data from less than ten individuals, while broken Iine indicates zero presence in the population. 


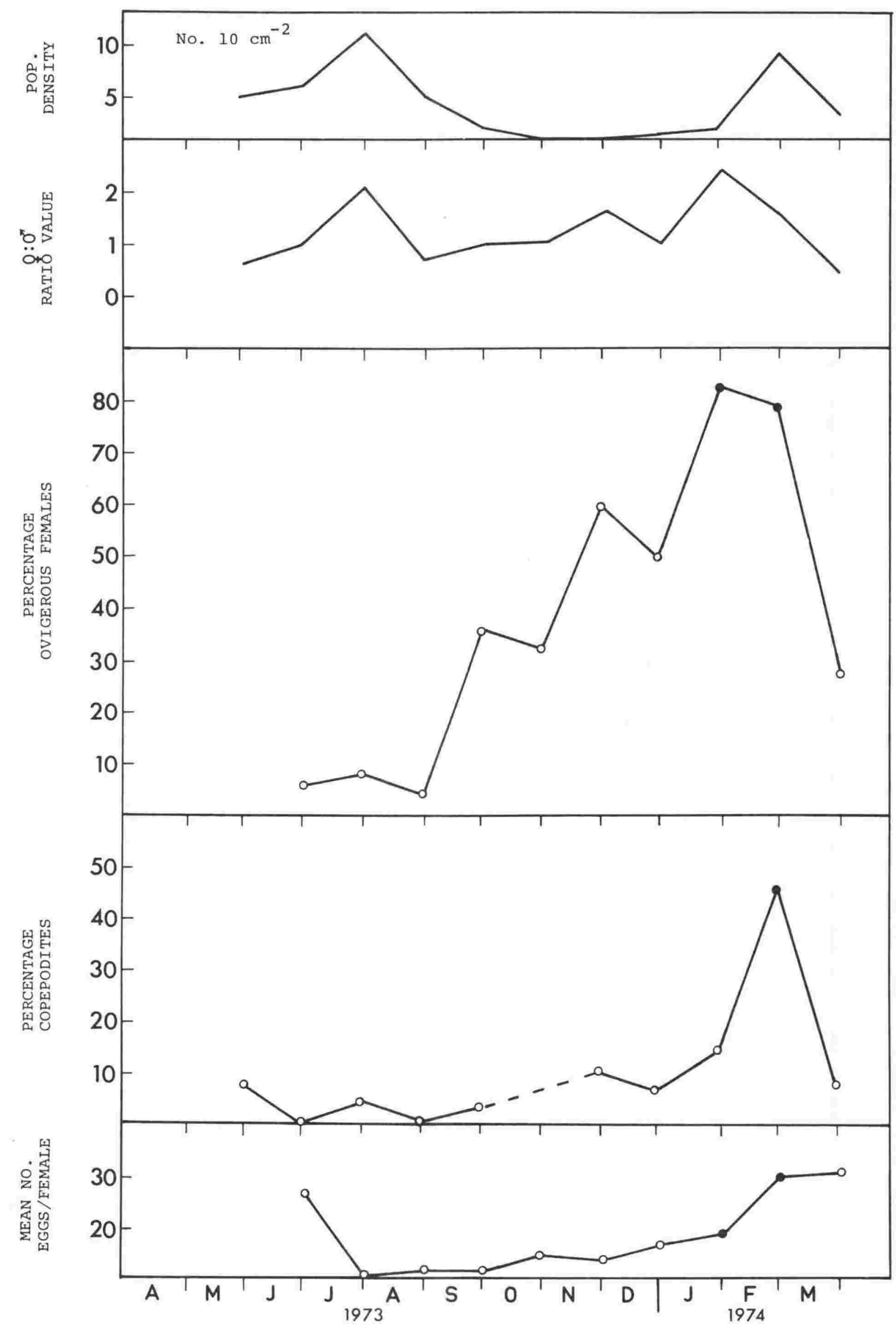


$18.91(n=45)$. Numbers were too small to lay any significance on the apparent seasonal trend in egg numbers. The highest percentage of copepodites ( $46.59 \%$ ) was recorded in February. The male population declines progressively following its maximum percentage in March (64\%) (Fig. 7). The mean annual sex ratio while favouring the females (1.17:1), was frequently reversed. Males predominated in March, May and August and a 1:I relationship existed in June, September, October and December. Amonardia perturbata Lang (Fig. 14).

This species had a distinct winter maximum in its breeding cycle. The maximum percentage of ovigerous females occurred in July through August when an average of $59.17 \%$ of the female population carried egg sacs and began to decline in september (56.85\%). There was a rapid decline from this percentage from September to December. The two egg sacs in A. perturbata contained a mean annual $45.35(n=140)$ eggs per female, which was the second highest among the species studied (Table 1). In the winter when the percentage of ovigerous females was large, the mean number of eggs per female increased aramatically to reach a september maximum of $72.65(n=53)$, then declined to the annual minimum of $35.28(\mathrm{n}=30)$ in November. The highest percentage of copepodites was recorded in september $(36.36 \%, \mathrm{n}=1006)$.

The mean annual sex ratio favoured males with a female:male ratio of $0.84: 1$, but for six months of the year (April-August, January) the females predominate. Reversals in sex ratio occur prior to or during periods of high population levels, as in other species. 
158.

FIG. 14 - Seasonal breeding pattern of Amonardia perturbata on the alga Corallina officinalis. Open circles represent data from less than ten individuals, while broken line indicates zero presence in the population. 


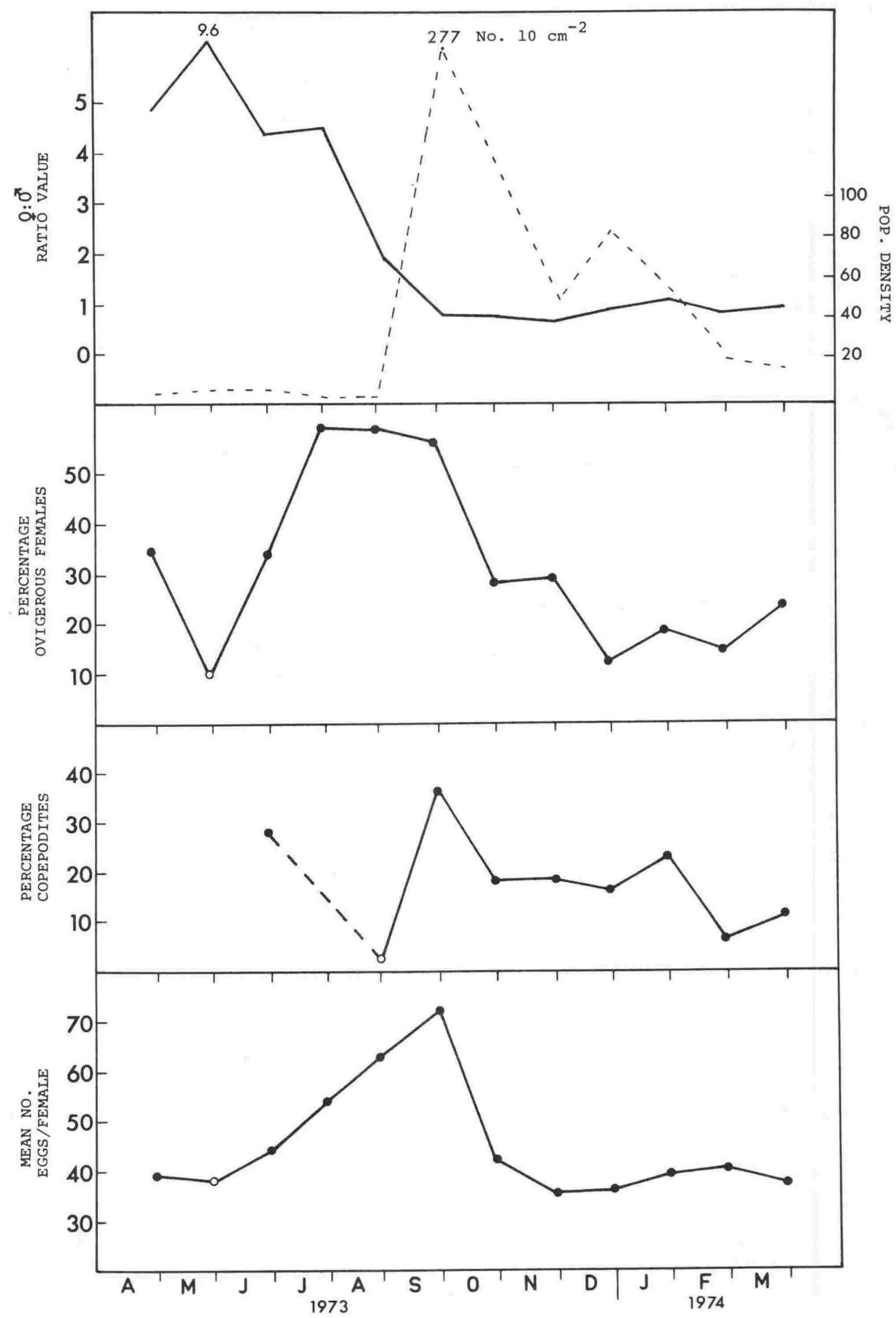


Robertsonia propinqua (T. Scott) (Fig. 15).

R. propinqua showed a marked difference from other species, not only in terms of total population density (Hicks in press b), but also in the timing of egg production. Ovigerous females were absent during the winter months and made their first appearance in October. Unfortunately the sample for November was lost, but the peak percentage of females with egg sacs appeared to occur in December (61.90\%). A drastic decline in ovigerous females followed, culminating in their complete disappeareance in April; the total breeding season lasting only 6 months. In each female the mean number of eggs in the twin egg sacs was $16.62(n=63)$, and was highest in October when the species is first recorded in the habitat. Copepodites similarly appeared first in october and rose to their greatest. proportion in February $(58.20 \%)$. The decline in copepodites must be equally as drastic as in the adults, since no young occur in April samples. As a percentage of the total mean annual population, copepodites represent $40.81 \%(n=906)$, which is the highest of any of the species studied.

Males dominated the adult population, with an annual ratio of females to males of $0.63: 1$.

Mesochra flava Lang (Fig. 16).

Maximum reproductive activity occurred in December (68.42\%) with a subsequent decline. No ovigerous females were observad in May. The mean annual percentage of ovigerous females was $32.63 \%(n=195)$. A seasonal trend in the number of eggs per female was indicated, with significantly low numbers $(\bar{x}=7.08$, $\mathrm{n}=12)$ in October rising to a mean of $12.81(\mathrm{n}=43)$ in January. This increase in the numbers of eggs per egg sac in 
FIG. 15 - Seasonal breeding pattern of Robertsonia propinqua on the alga Enteromorpha intestinalis. Open circles represent data from less than ten individuals. The November sample is not represented. 


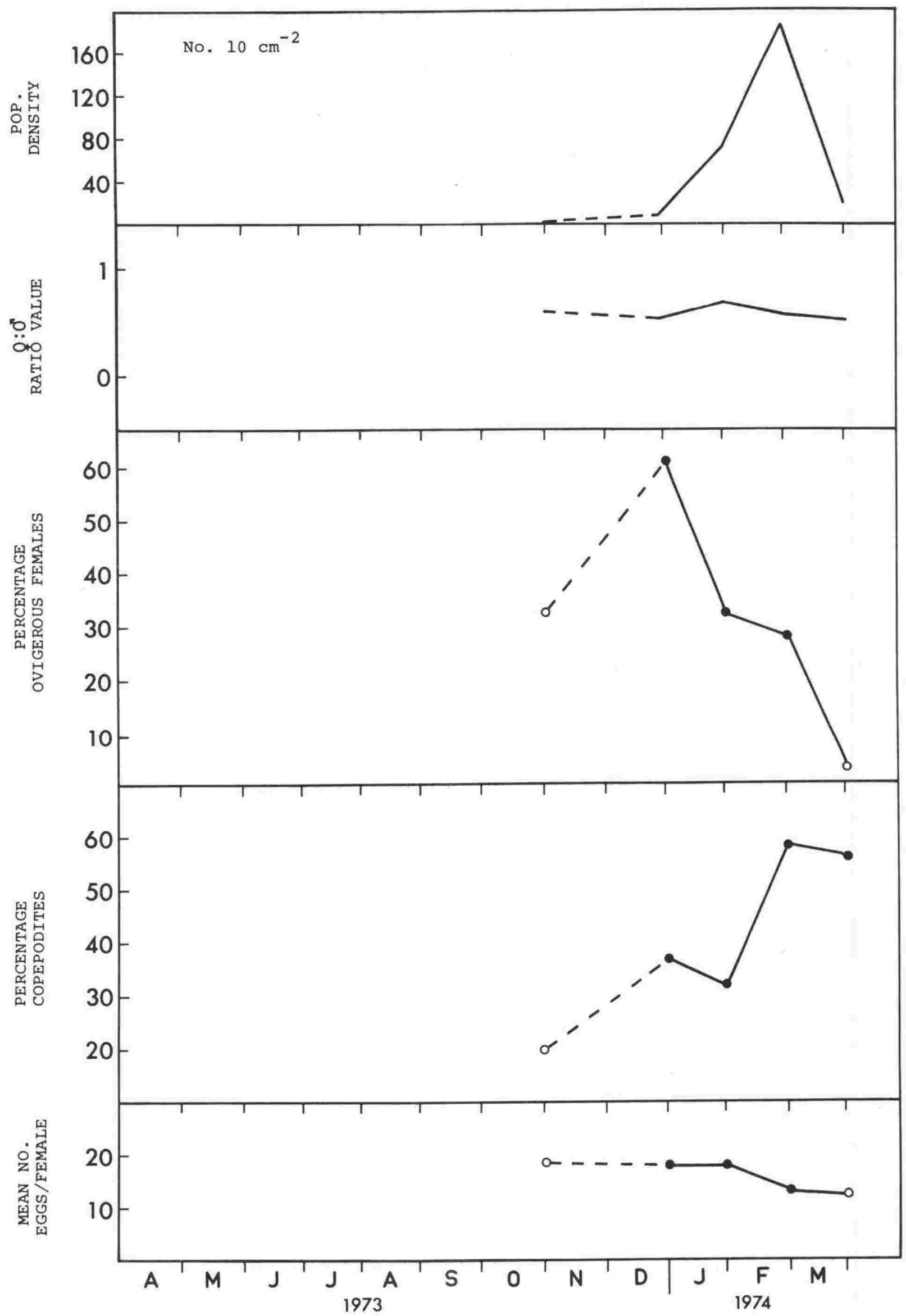


FIG. 16 - Seasonal breeding pattern of Mesochra flava on the alga Enteromorpha intestinalis. Open circles represent data from less than ten individuals, while broken lines indicate zero presence in the population. The November sample is not represented. 


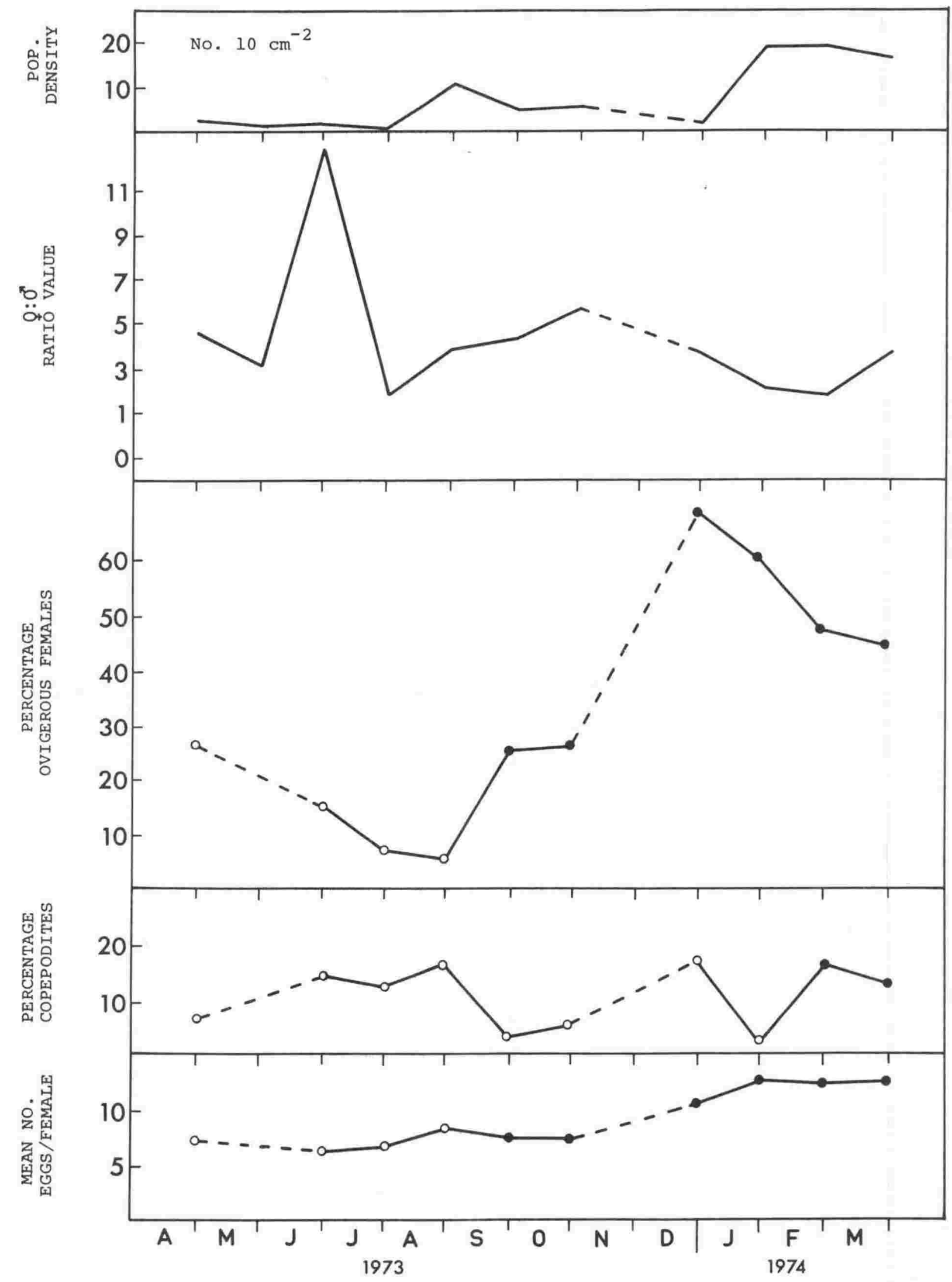


the summer accords with the pattern in some other species, e.g. Porcellidium dilatatum, Neopeltopsis pectinipes. The percentage of copepodites at no time rose above $18 \%$, wi.th an annual mean of $10.80 \%(n=64)$. Juveniles are present in all months except May and do not appear to attain significant maxima.

At no time does the male population exceed $32 \%$ which gives a mean adult female to adult male ratio of $3.17: 1$.

Orthopsyllus linearis (Claus) (Fig. 17) •

Ovigerous females were present in all months with the minimum proportion ( $9.09 \%$ ) in June. Two periods of maximum breeding activity occurred, one in autumn (46.97\%) and the other in early spring (36.67\%). The mean annual number of eggs in the single egg sac was $22.15(\mathrm{n}=187)$, and shows a significant seasonal variability. The maximum $(\bar{x}=30.00$, $\mathrm{n}=29$ ) occurred in october and decreased to a mean of 17.00 $(n=11)$ in February. The range in the number of eggs per ovisac was between 10 and 45 . The highest percentage of copepodites in the population was in October (44.76\%) while the mean annual figure was $31.41 \%(\mathrm{n}=1682)$.

Femaies were subordinate with an annual sex ratio of 0.65:1 with no seasonal reversal evident.

Laophonte cornuta Philippi (Fig. 18).

A detailed account of the breeding pattern of $\underline{L}$. cornuta is not possible owing to the low annual population density. The maximum percentage of females with eggs apparently occurred in November $(60.00 \%)$ with a further peak (42.86\%) in March. Mean annual numbers of eggs in the single egg sac was 15.45 $(n=14)$ and little importance can be placed on the apparent seasonal trend noted in Fig. 18. Copepodites reached their 
163.

FIG. 17 - Seasonal breeding pattern of Orthopsyllus linearis on the alga Corallina officinalis. open circles represent data from less than ten individuals. 


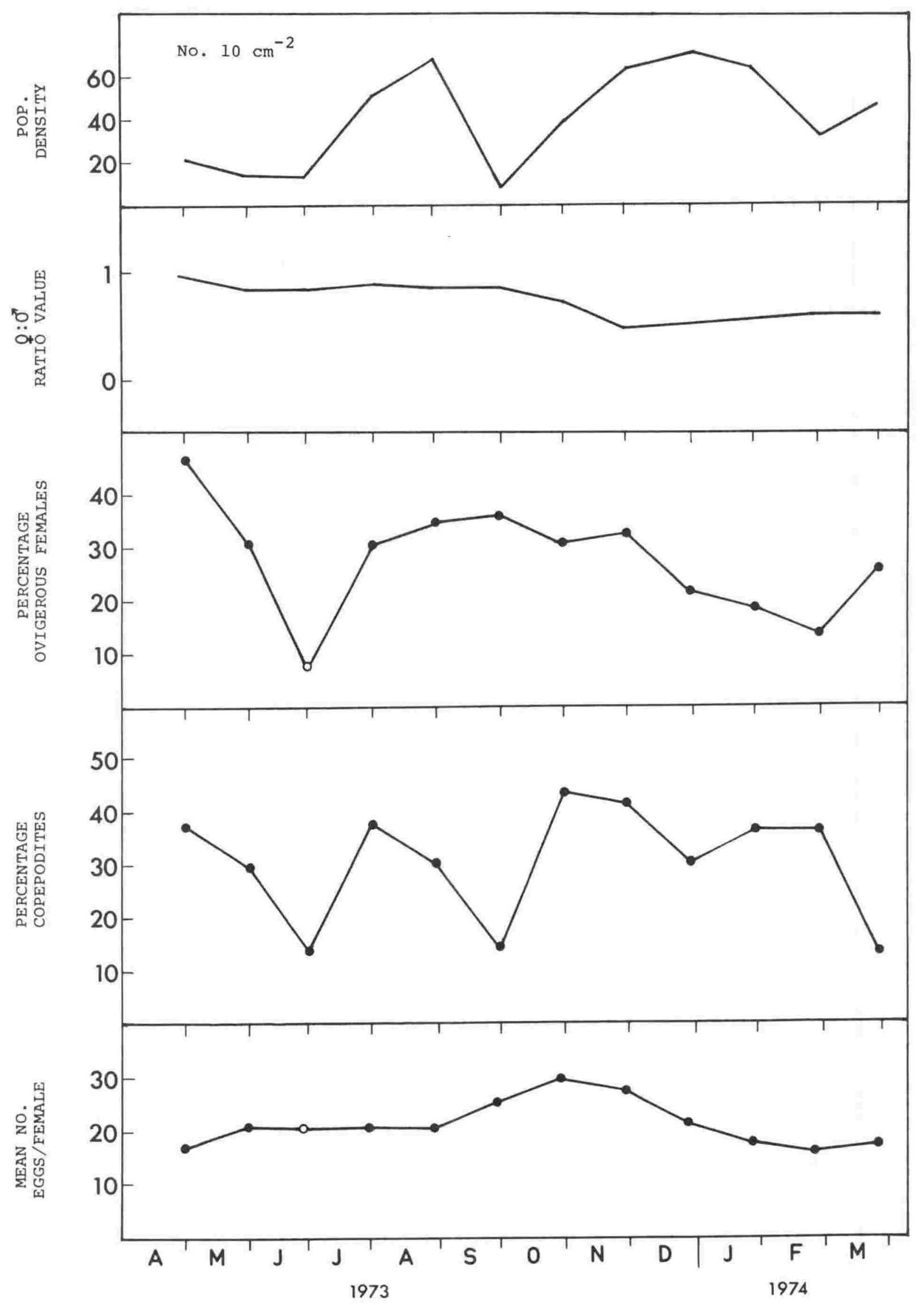


FIG. 18 - Seasonal breeding pattern of Laophonte cornuta on the alga Zonaria turneriana. Open circles represent data from less than ten individuals, while broken lines indicate zero presence in the population. 


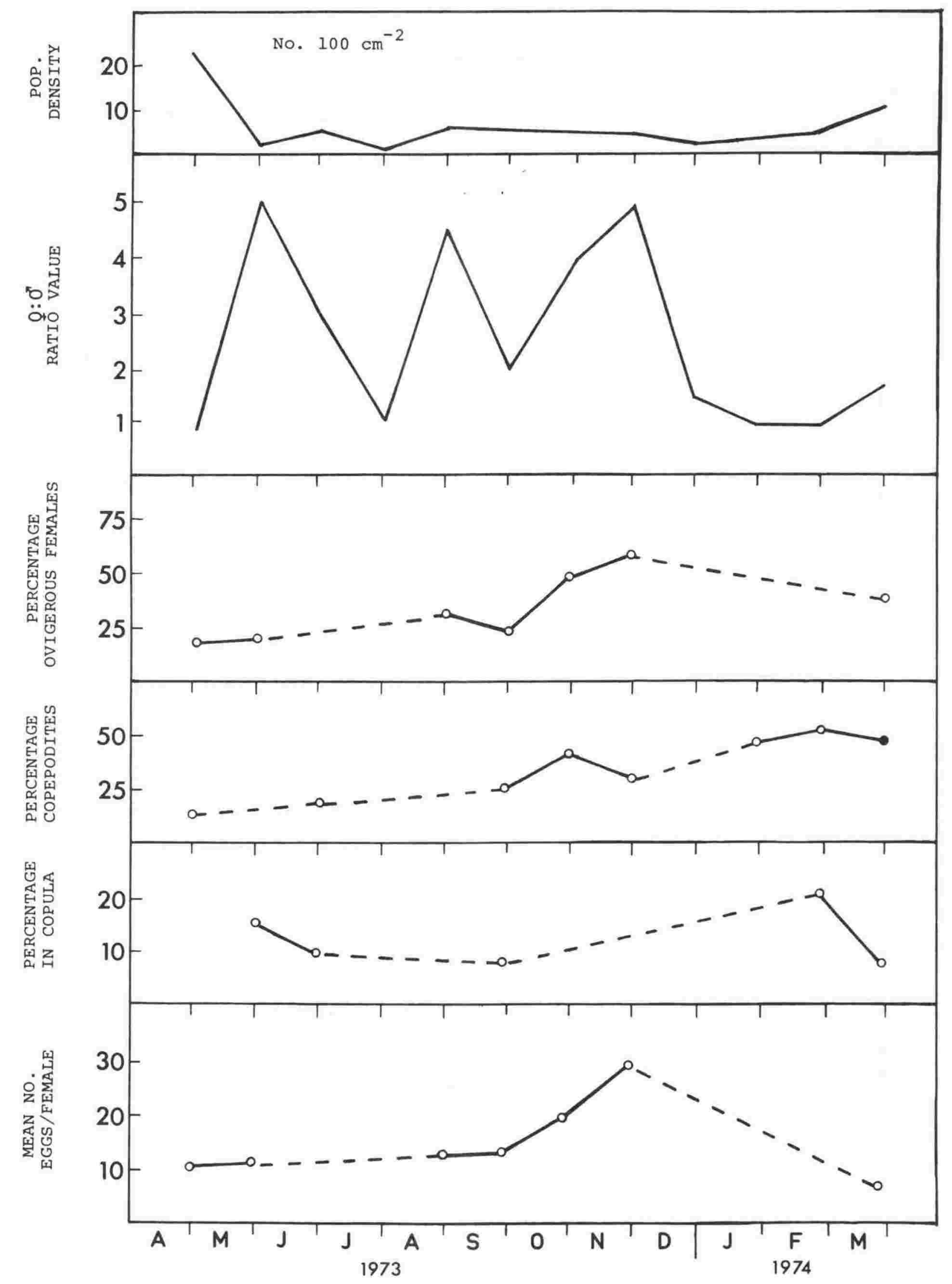


166.

FIG. 19 - Seasonal breeding pattern of Laophonte cornuta var. nigrocincta on the alga Corallina officinalis. Open circles represent data from less than ten individuals, while broken lines indicate zero presence in the population. 


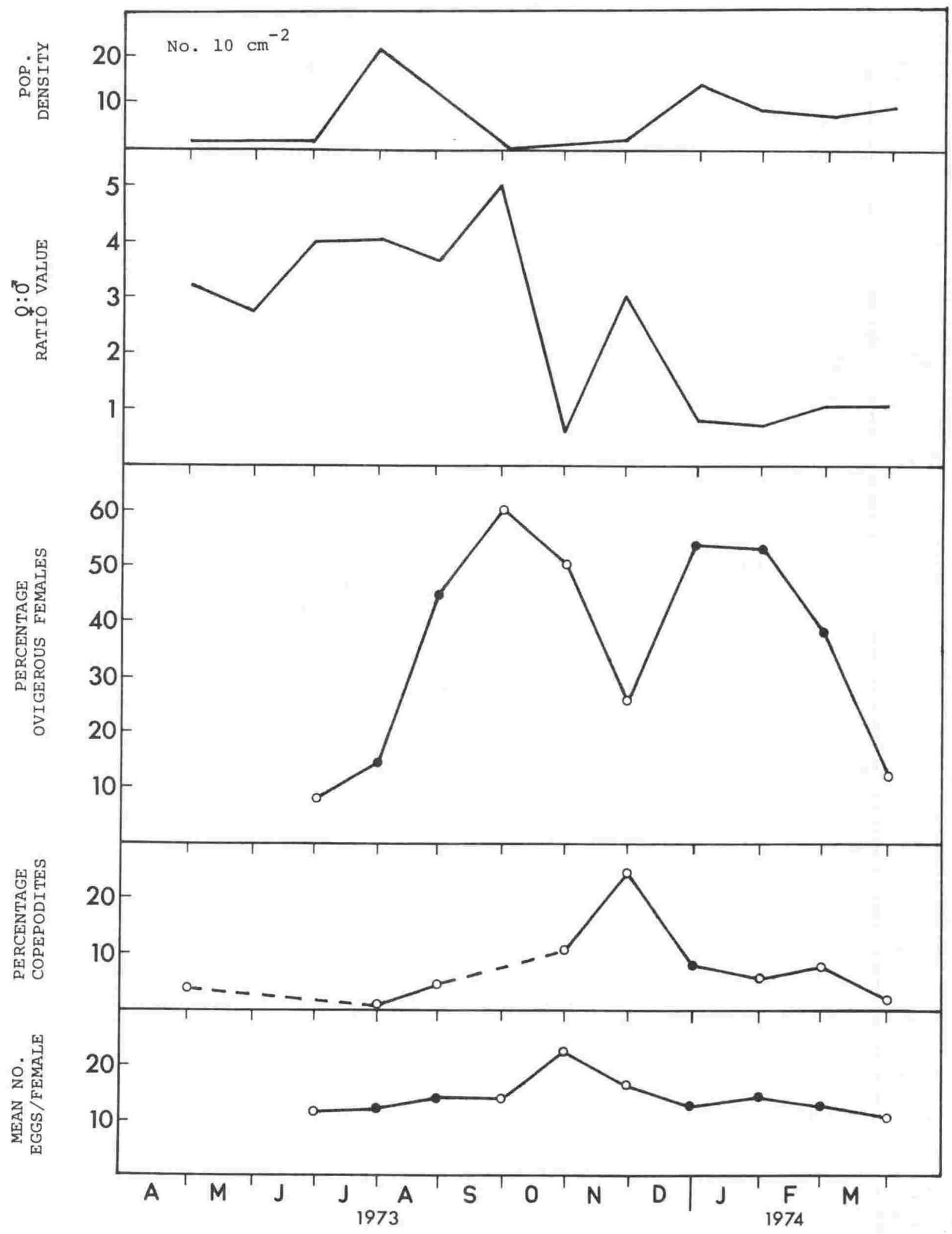


FIG. 20 - Seasonal breeding pattern of paralaophonte meinerti on the alga Corallina officinalis. Open circles represent data from less than ten indjviduals. 


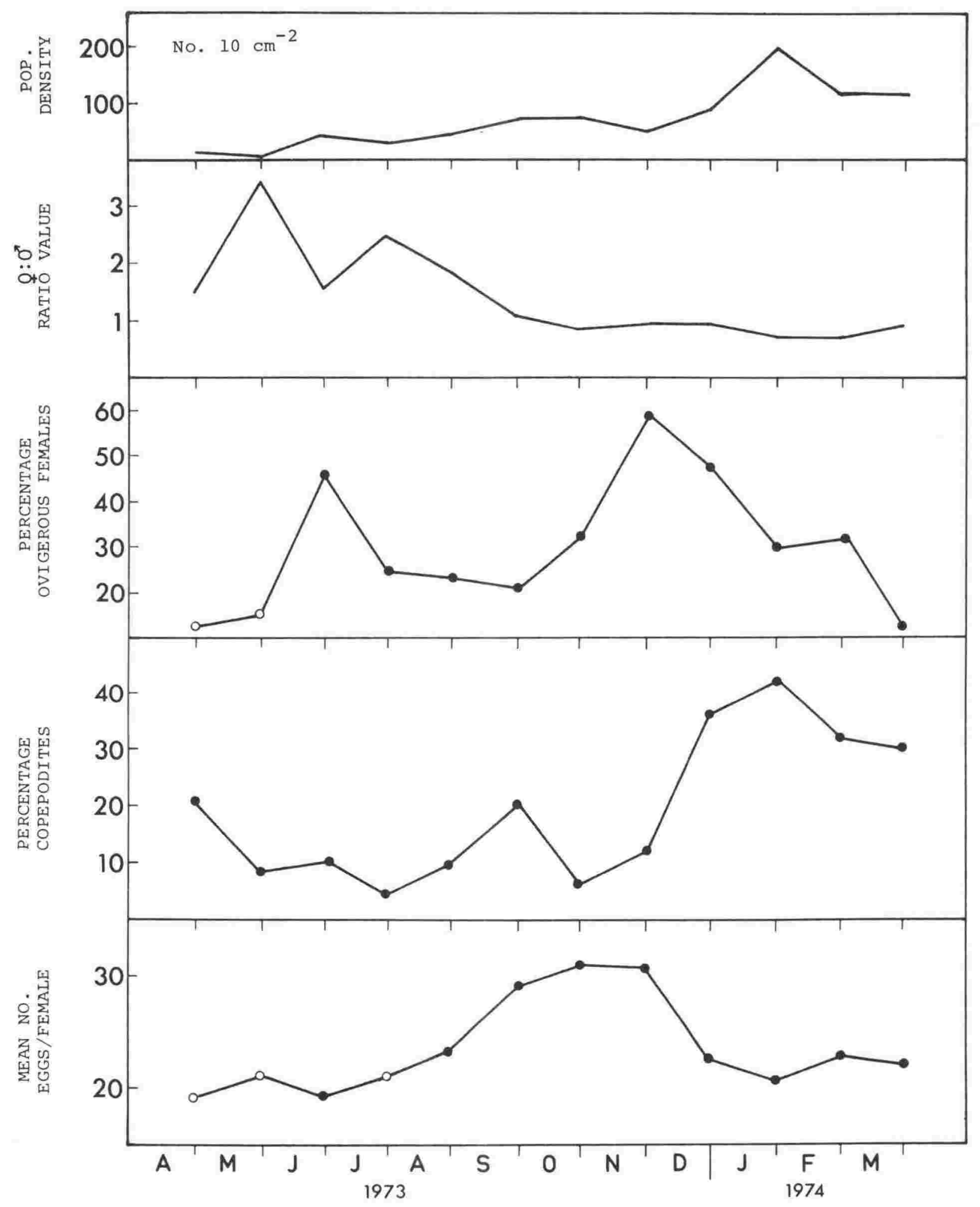


$(31.00, \mathrm{n}=30)$. During the summer, autumn and winter the number of eggs per female remained below the annual mean. The percentage of copepodites increased to the seasonal maximum of $42.02 \%$ in January.

Throughout the year the adult female population declined progressively as the population density increased; Males predominated from October to March and the mean annual sex ratio was 1.42:1 in favour of females.

Lourinia armata (Claus) (Fig. 21).

Ovigerous females were first observed in July; were absent again in october; reached their annual maximum percentage in December (68.75\%); and were absent again by April. Low numbers of ovigerous females prevented accurate assessment of any seasonal trend in eggs per female. The mean annual number of eggs per sac was $15.58(n=35)$ (Table 1$)$. Copepodite percentages reached their apparent maximum in February. Although this is a circumtropicai (Wells 1967, Hicks in press a) eurythermic species, it is at or near its southern distribution limit in New Zealand and this may explain the absence of breeding activity in early winter.

Adult females predominated with an annual sex ratio of $1.33: 1$, but males were in greater relative numbers in July.

EGG NUMBER - LENGTH RELATIONSHIP

A relationship has been shown between mean length of females and mean number of eggs carried. Measurements of three abundant species have been made at a time when the minimum number of eggs per female was recorded, and compared with measurements taken over the period of maxirnum egg production. 
FIG. 21 - Seasonal breeding pattern of Lourinia armata on the alga Corallina officinalis. Open circles represent data from less than ten individuals, while broken lines indicate zero presence in the population. 


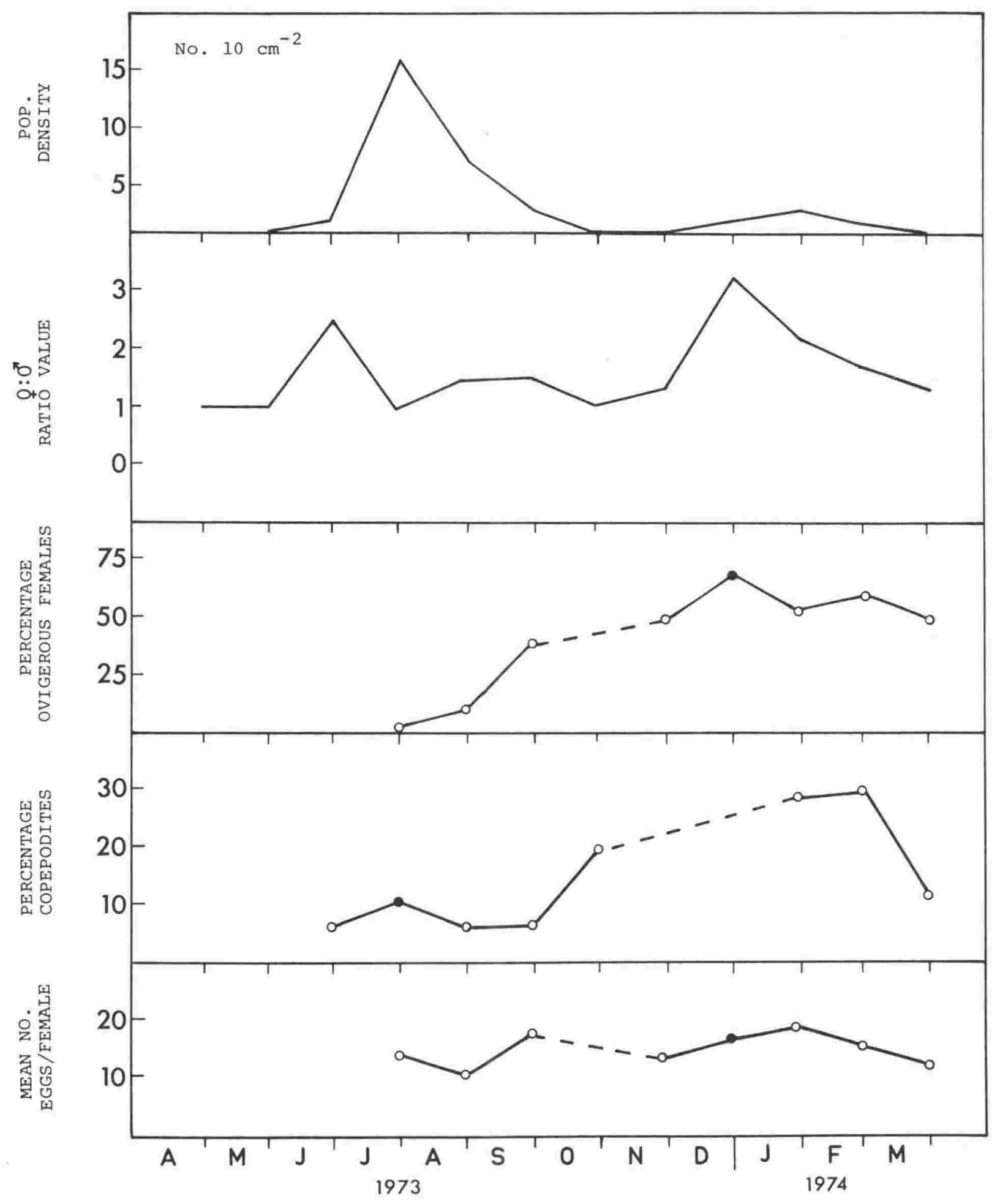


In Porcellidium dilatatum the mean length of females in July was $1.151 \mathrm{~mm}(\mathrm{n}=46)$ while in December the mean length was $1.212 \mathrm{~mm}(\mathrm{n}=66)$, an increase of $0.061 \mathrm{~mm}$. Orthopsyllus linearis measured $1.302 \mathrm{~mm}(\mathrm{n}=38)$ in February and $1.352 \mathrm{~mm}$ $(n=42)$ in October, a difference of $0.050 \mathrm{~mm}$. Amonardia perturbata, which showed the most noticeable seasonal fluctuation in numbers of eggs per female increased from a November minimum of $0.992 \mathrm{~mm}(n=58)$ to a maximum in september of $1.089 \mathrm{~mm}$ ( $\mathrm{n}=51$ ), an almost $10 \%$ increase in length. In other species where seasonal variability in egg number is observed a similar relationship to size of female probably exists. Such a relationship between size of females and egg number is well known in other cxustaceans.

In order to quantify reproductive activity and total fecundity of a given species, however, it has been necessary to disregard this relationship so that a true comparison between species can be obtained.

\section{DISCUSSION}

GENERALIZED PATTERN OF BREEDING ACTIVI'TY

Little similarity is seen with regard to the reproductive activity of species included in this study. No two species are alike in their breeding pattern and all indices of breeding activity viz. percentage ovigerous females, percentage copepodites, percentage in copula, mean number of eggs per female and the total population density show almost as many variations as there are species (Fig. 22).

Nevertheless certain generalizations may be made. The majority of the seaweed-dwelling forms included here demonstrate varying degrees of prolonged or continuous repxoductive activity 
FIG. 22 - Calendar of reproductive activity and the relationship with population density of twenty algal-dwelling copepod species. Solid bars represent the percentage ovigerous females; closed circles represent the mean number of eggs per female; open circles represent the percentage copepodites; triangles represent maxima of population density for each species. Data are based on figures above the mean annual percentage. 


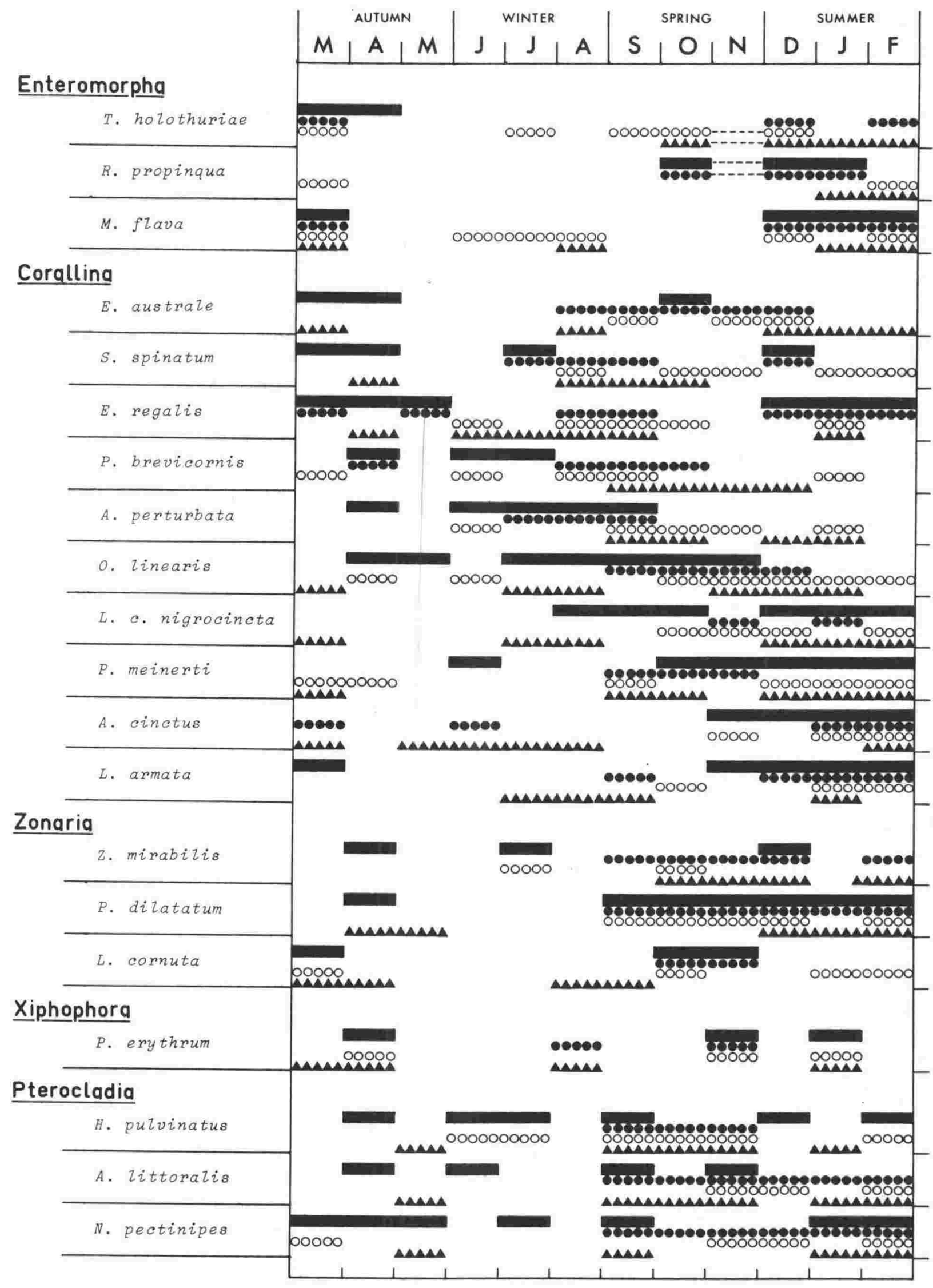


which contrasts with the restricted breeding periods of many sediment-dwelling harpacticoids (see Barnett, 1970, Lasker et al. 1970, Harris 1972, Coull \& Vernberg 1975). Continuous or protracted breeding seasons in temperate marine or brackish water benthic harpacticoids has been reported by Barnett (1970), Bodin (1972a, b, c), Harris (1972), Heip (1973), McIntyre \& Murison (1973) and Coull \& Vernberg (1975) and also in the tropics by Govindankutty \& Nair (1972). Although most species mentioned by these authors sustain their breeding they did show distinct peaks of breeding activity at some time during the year.

The index used by previous authors to signify maximum periods of reproductive activity (\% ovigerous females) when applied here shows that a large number of species (40\%) reach maximum breeding activity during the autumn months. Such an autumnal peak is similar to platychelipus littoralis from Southampton Water, England (Barnett 1970), the French populations of Pseudobradya minor (Bodin 1972a) and Microarthridion fallax (Bodin 1972b, c), and Halectinosona sp. (Coull \& Vernberg 1975) from South Carolina. These differ from most other recorded benthic copepods which tend to exhibit spring and summer breeding maxima. Because of the predominance of ovigerous females in autumn in a large number of overwintering species, the levels of copepodites in the population and the peak in the number of eggs per female usually increase to a maximum in late winter, spring or summer (Fig. 22). Such increases lead, in general, to the observed maxima in total population density in the habitat (Hicks in press b) and it is perhaps these criteria rather than the percentage ovigerous females which are of more importance when assessing the effects reproductive activity has on the overall population structure. 
Among species studied, there tends to be a relationship between the number of eggs per female and the percentage ovigerous females in the population. That is, species with a low mean number of eggs per female had a high mean percentage of ovigerous females and vice versa, except for Neopeltopsis pectinipes. The species also fall into five main groups (Fig. 23) unified by coincident times of peak copepodites and egg numbers:

1). Those with a high mean percentage of egg bearing females in the population but with a low mean number of eggs per female. These are primarily spring and summer breeders (in terms of peaks in egg number and copepodites - Fig. 22) and it is notable that all of these species belong to either the porcellidiidae or Peltidiidae.

2). N. pectinipes is in some ways a special case with an extremely high reproductive capacity, indicated by a high mean percentage of ovigerous females and a high mean number of eggs (Table 1). It is possible that this capacity has evolved to compensate for a very low overall percentage occurrence of females in the population (23.48\%). N. pectinipes apparently does not produce pelagi.c young, as large numbers of early juveniles are invariably found on the algal substrate. 3). Those with a moderate mean percentage of ovigerous females in the population but a large number of eggs per female. These species breed mainly in winter and spring (in terms of eggs/ female, : copepodites - Fig. 22). A good example is 'A. perturbata which produces its greatest number of young in September following the winter increase in ovigerous females and the dramatic rise in the number of eggs per female. 
FIG. 23 - Relationship of mean egg number per female to the mean percentage of ovigerous females of each species. Grouping boundaries are arbitrary and serve for visual assessment only.
A.1 = A. littoralis
P.m $=$ P. meinerti
E.r $=$ E. regalis
$0.1=\underline{0}$. linearis
P.e $=$ P. erythrum
$\mathrm{H} \cdot \mathrm{P}=\underline{\mathrm{H}} \cdot \underline{\text { pulvinatus }}$
P.d $=\underline{\text { P. }}$ dilatatum
$z \cdot m=\underline{z}$. mirabilis
L. $a=$ L. armata
$E \cdot a=E$. australe
$A \cdot c=$ A. cinctus
$T \cdot h=T$. holothuriae
M. $f=$ M. flava
P.b $=$ P. brevicornis
$L \cdot n=L$. cornuta nigrocincta
$\mathrm{S} . \mathrm{s}=\mathrm{s}$. spinatum
L. C $=$ L. cornuta
$A \cdot p=$ A. perturbata
$\mathrm{R} \cdot \mathrm{p}=\mathrm{R}$. propinqua
$N \cdot p=N$. pectinipes 


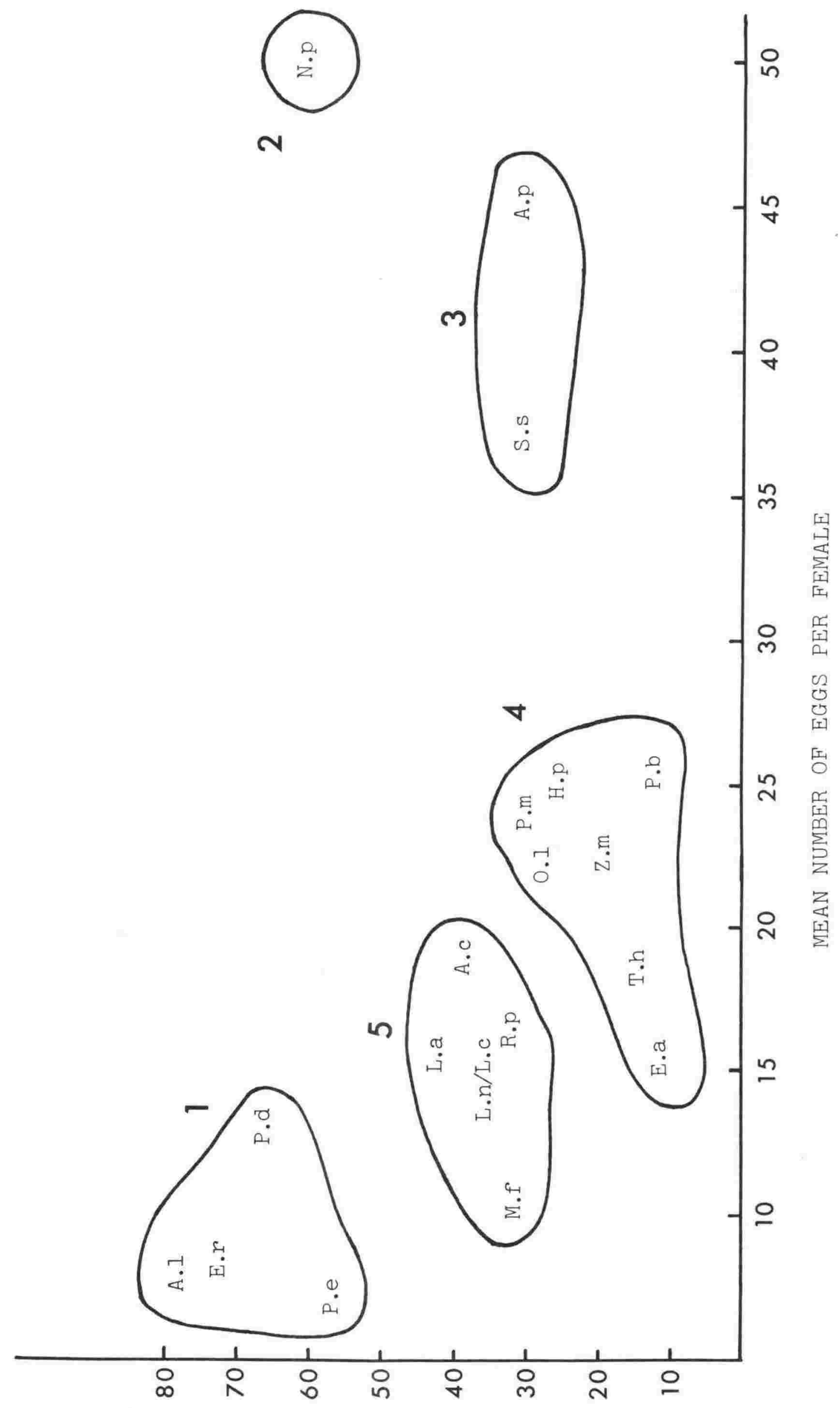

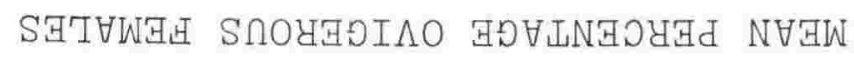


S. spinatum, however, produces its maximum level of copepodites in mid-summer.

4). Those with a low mean percentage of ovigerous females but a moderate number of eggs per female. This group contains mainly late winter and spring breeders (in terms of eggs/female, \% copepodites - Fig. 22) with T. holothuriae producing most eggs per female in autumn and $\underline{E}$. australe and $\underline{P}$. meinerti most copepodites in early summer.

5). Those species with an intermediate level of ovigerous females and number of eggs per female. These are mainly summer and autumn breeders (in terms of eggs/female, \% copepodites)

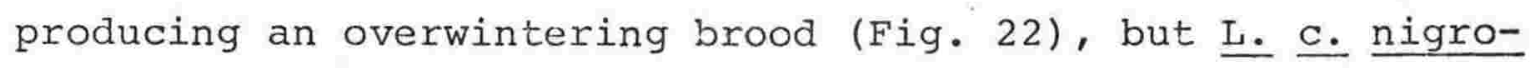
cincta reaches its maxima in late spring.

From this information it is apparent that most species must have a certain minimum reproductive capacity in order to survive. Whether a species has a larger number of eggs per female or a larger percentage of ovigerous females in the population to achieve this reproductive capacity may have some bearing on the time at which the main period of breeding activity takes place. For example, the level of ovigerous females in groups 3 and 5 (Fig. 23) are about the same but since group 3 breeds mainly in winter, the production of a higher number of eggs would probably counteract greater juvenile mortality at this time. The production of a brood of eggs before the coldest part of the winter as in group 5 is advantageous to these species in that extra food energy may be converted into eggs during a time of food abundance and warmer temperatures between spring and autumn, thus permitting an earlier recruitment in the following spring. A broad concave abdomen characteristic of the females in group 1 serves to 
protect the egg sacs, but in so doing may anatomically limit the females to small brood sizes. Compensation for a low number of eggs per female in all these species is evident in a continuously high percentage of ovigerous females in the population. In A. littoralis and E. regalis for instance the percentage of females with eggs does not fall below $50 \%$.

In the absence of conspicuous factors initiating and governing the breeding characteristics of all species, only the more recognized parameters are considered here. In this way it is hoped the relative importance of individual or combined features may be assessed.

\section{EXTRINSIC DETERMINANTS}

\section{Effect of Temperature}

Temperature is thought to be the crucial environmental factor affecting sediment-öwelling copepod reproduction (Muus 1967, Barnett 1970, Harris 1972, Heip 1973) with distinct periods of increasing reproductive activity (i.e. $\%$ females with eggs) correlated with rising seawater temperatures. There is little apparent correlation with temperature in the present study, except perhaps in the timing and initiation of breeding in R. propinqua, A. cinctus, M. flava and L. armata where reproductive activity increases with a rise in water temperature. Conversely, A. perturbata and $\underline{P}$. brevicornis show the opposite relationship with increasing temperature, having their peaks of reproductive activity in autumn and winter. The fact that most species show little correlation of breeding activity with temperature could be due to the small difference between mean summer and mean winter temperatures at Island Bay. In Harris' (1972) study this differential was $11-12^{\circ} \mathrm{C}$ (and even greater in Barnett's (1970)) while the range at Island Bay is only $6-7^{\circ} \mathrm{C}$. 
The narrow continental shelf in the study area and strong winds experienced in Cook Strait (Brodie 1960:250) give these waters a more oceanic character. Summer warming of coastal waters in this area is therefore limited. Continuous breeding, similar to that found in the harpacticoids, has been observed previously in a number of other central New Zealand taxa e.g. Mytilidae (Flaws 1975), Sphaeromatidae (Jansen 1971, Fincham 1974), with peaks of breeding activity occurring at different times. Harpacticoids from other localitiës around New Zealand where greater summer-winter temperature ranges prevail, may very well exhibit more distinct periods of reproductive activity. Furthermore, Bodin (1972b) recorded continuous breeding of Asellopsis intermedia from the semiestuarine biotope of Fouras Nord (La Rochelle, France) which was unlike the distinct seasonality of the species in Scotland (Lasker et al. 1970), although the breeding maximum occurred at the same time. Bodin's samples, however, were bimonthly and of only nine months duration. The difference in physical factors including temperature is likely to be responsible for such variability.

\section{Influence of Food Supply}

Food supply can play an important role in the control of reproduction of copepods. Feeding greatly affects the rate of maturation and also the rate of egg production (Marshall \& orr 1955, Smyly 1970) and, furthermore, the onset of egg-laying and naupliar development may be delayed in some species by inadequate food supply (Smyly 1973, Coull \& Dudley 1976). 
Phytal-dwelling copepods exhibit peak breeding activity at different times of the year (Fig. 22). With no noticeable perennality observed in the macrophytic substrates (Hicks in press a) algal-dwelling food organisms, by occurring in welllit shallow waters and also perhaps gaining considerable mineral and energy requirements from the seaweed itself, may not show large seasonal fluctuations in abundance such as primary food items occurring in the local pelagic environment (see Bradford 1972). Although a spring and summer maximum in food material may occur, it is suspected that food (diatoms, bacteria, fungi, algal mucilage etc) for shallow water algaldwelling copepods is not seasonally limiting. Thus different physiological responses to available food by separate species must be operating. This regulates their reproductive activity to the extent of allowing, in most species, continuous breeding. Very little comparative evidence of physiological differences between species is available, although Harris (1973) shows that differing proportions of food assimilated are used in. growth, metabolism, moulting and egg production respectively in three copepod species.

\section{Salinity: the Special Case of Robertsonia propinqua}

In an environment such as supralittoral rockpools where physicochemical extremes are experienced, no other species appear to be influenced by salinity to the extent of Robertsonia propinqua. Salinity appears to have a synergistic effect with temperature in the onset of reproduction in this species. R. propinqua is circumtropical and euryhaline and is well documented as occurring on thick growths of filamentous 
algae in saline tide pools and Australian saline lakes (Bayly \& Williams 1966, Bayly 1970, Hamond 1973a, b). This type of habitat is similar to the supralittoral pools from which the species is collected in Wellington. Bayly \& Williams and Bayly record $\mathrm{R}$. propinqua during March, September and December only, and established a salinity range for the species of $23.4-61.9 \%$. Hamond (1973b:426) notes, "... ovigerous females were found only at $10 B$ (Bayly's station in December 1969), but for such a scarce species the negative data probably reflect paucity of observation rather than seasonality of reproduction". Their observations, however, conform to the seasonal pattern of reproduction found for R. propinqua in N.Z. (Fig. 15), with the maximum percentage of females with eggs occurring in December.

The appearance of $\mathrm{R}$. propinqua in the october samples occurs at a time of rising temperatures and salinities (Hicks in press a). Unfortunately no data are available for November when the monthly mean salinity drops to $16.2 \%$, but breeding intensity increases to its apparent peak in December, with the rising salinity. The peak of copepodites and total population density occurs during the annual maximum of supralittoral temperature and salinity in February. Thus it seems that the combined temperature/salinity regime of about $30-35 \%$ oo at 13-14 ${ }^{\circ} \mathrm{C}$ determines the reappearance of $\underline{R}$. propinqua into the population and the consequent onset of reproduction. The possibility of overwintering resistant eggs in this species should not be dismissed (see Bayly 1970), as recent evidence for the neritic Calanoida (Zillioux \& Gonzales 1972, Grice \& Gibson 1975) suggests that such quiescent eggs are rather more prevalent in copepods than previously recognized. 
Factors such as the ratio of females to males in the population, population density, competition etc. also appear to be important features which could govern the pattern of breeding within each species.

\section{INTRINSIC DETERMINANTS}

Sex Ratio \& Population Density

Sex ratios vary markedly amongst copepods and experiments have shown that sex may be influenced by a. range of environmental and genetic factors such as temperature, inbreeding etc. (see Volkmann-Rocco 1972). Furthermore, biotic determinants such as predation intensity, population density and food availability have been suggested as influencing sex ratio (Heinle 1970, Moraitou-Apostolopoulou 1972). In the study area, sex ratios fluctuate widely from season to season (see figures) and as population levels of most species are not directly related to temperature which would influence sexual differentiation, it is more likely to be related to the intrinsic effects of population density. In some species (E. australe, $\underline{\mathrm{P}}$. dilatatum, T. holothuriae, M. flava, P. brevicornis, N. pectinipes, I. armata,

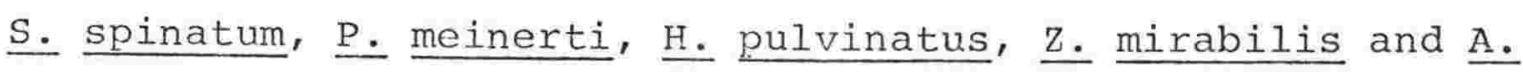
perturbata) the sex ratio varies relative to the density of the total population with females occurring in larger numbers when the population is near its lowest levels. Paradoxically, in others (A. cinctus, L. C. nigrocincta and A. 1ittoralis) females are more numerous when the population level is at its highest. No obvious relationship exists for p. erythrum, E. regalis,

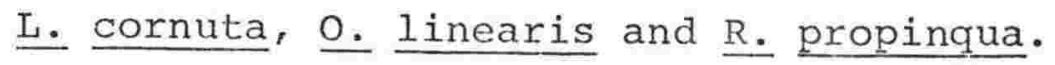


In the majority of species the observed variations in sex ratio over the year appear to be a homeostatic mechanism for maintaining the population at a viable level throughout the year (Heinle 1970). Females predominate during periods of low population density which would ensure a sufficiently large number of females in reproductive condition and would be an adaptation for survival at low population densities. An alternation to a predominance of males takes place during periods of high total population density (which is usually related to the periods of copepodite maxima). The mechanism involved in such alternation of sex ratio is unknown but may be by way of a hormonal pathway in response to the level of physical contact.

The scarcity of females in $\mathrm{O}$. linearis, $N$. pectinipes and T. holothuriae during this study could result from a greater mortality during the subadult and maternal moults or alternatively the high incidence of "maleness" in the latter may be due to an increased homozygosity within the population. This species is very sensitive to inbreeding and since they are commonly found in supralittoral tidepools may represent isolated populations which have little gene exchange with each other (Dr B. Volkmann pers. comm.). This may also be the case for $\mathrm{R}$. propinqua which is a strictly seasonal inhabitant of the same tidepools.

\section{Interspecific Competition}

Interspecific competition may provide an additional control to breeding patterns. Within the densely populated Corallina assemblage a succession in reproductive activity is evident (Fig. 22). The upsurge in winter breeding of $\underline{A}$. perturbata is followed by increases in O. linearis, L. C. nigrocincta, P. $\underline{\text { meinerti }}$ and the summer breeding of $\underline{A}$. cinctus and $\underline{L}$. armata, all 
182 .

of which inhabit the surface of the holdfast sediments of Corallina. This reproductive separation might ensure a reduction in competition between coexisting species. Greater niche availability caused by the decline of other species in winter has been utilized by $A$. perturbata which has selected for a high reproductive rate in this season (Table 1). Similar cases of reproductive partitioning have been noted by Heip (1973) and Coull \& Vernberg (1975) in brackishwater and estuarine copepods.

\section{LIFE CYCLE OF Porcellidium dilatatum}

The number of generations produced per year by all of the seaweed-dwelling species and the length of life of each species is unknown and only detailed studies on growth from field data will resolve this question. Harpacticoid longevity and brood number varies greatly in laboratory populations (see Rosenfield \& Coull 1974 for review), but in natural populations the evidence points to only one to two generations per year (Barnett, 1970, Lasker et al. 1970, Dinet 1972). However, based on an analysis of the time between peaks in mating couples and maxima of

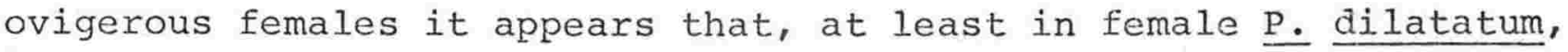
3 generations are produced annually (Fig. 6). From the time of sperm deposition by the males to the liberation of the young, the period of egg maturation within the female of this species is about 3-4 months. The development period from hatching of the juvenile to copulation as an adult would be 4-5 months. A total life cycle of female $\underline{P}$. dilatatum is thus about 8 months, but estimates of life span are complicated by egg-laying and development occurring throughout the year. These estimated times compare favourably with the findings of Barnett (1970) who recorded an egg maturation period of 4 months for $\underline{P}$. littoralis 
and 8-10 months for P. laophontoides. Lasker et al. (1970) indicated an egg maturation period of 9 months and a 12 month life span in A. intermedia. Total longevity of the former species was 6 (12?) months for P. littoralis and 13 months for P. laophontoides. In all these species the males show a much shorter life span than the females. In $\underline{P}$. dilatatum, as with

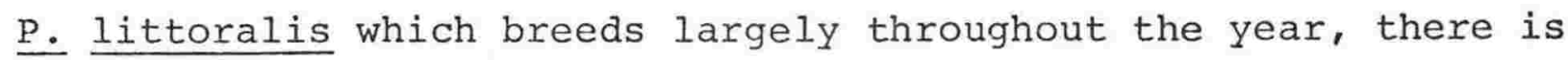
a tendency for a reduced life cycle and more than one generation annually.

\section{CONCLUDING REMARKS}

It has been reported that pronounced seasonal changes in population density occurs in the algal-dwelling harpacticoid copepods at Island Bay, Wellington (Hicks in press b). Such temporal variability is largely the result of periodic fluctuations in the reproductive activity of the harpacticoid species. The initiation and regulation of breeding patterns is a multifactorial process with temperature, salinity, nutritional requirements, competition and possibly population density appearing to variably affect different species. This is in contrast to the overriding effect of temperature seen in the studies on sediment-dwelling species. Total reproductive capacity is higher in algal-dwelling harpacticoids than in the more extensively researched interstitial species (cf. Harris 1972). Egg number is in general similar to other epibenthic forms (see Lasker et al. 1970) but total reproductive capacity is probably higher in algal-dwellers owing to the longer overall duration of reproductive periods. High numbers of eggs per female and mean percentage of ovigerous females in algal-dwelling species could be a response to a less stable environment and/or to higher levels of predation and competition. 


\section{ACKNOWLEDGEMENTS}

My sincere thanks go to Dr Robert G. Wear (Zoology Department, Victoria University of Wellington), who supervised the study; Dr Janet M. Bradford (N.Z. Oceanographic Institute), Dr Anthony A. Fincham (British Museum of Natural History) and Professor John B.J. Wells (Zoology Dept. V.U.W.) for their helpful discussion and constructive criticism of the manuscript. This paper formed part of a $\mathrm{Ph}$.D. thesis presented at Victoria University of Wellington; the first year of the study was conducted during tenure of a N.z. Postgraduate Research Scholarship from the University Grants Committee.

\section{LITERATURE CITED}

BARNETT, P.R.O. 1966: The comparative development of two species of Platychelipus Brady (Harpacticoida). In "Some Contemporary Studies in Marine Science," $\overline{B A} R N E S, H$. (ed.). G. Allen \& Unwin Lta, London: 113-127.

1970: The life cycles of two species of Platychelipus Brady (Harpacticoida) on an intertidal mudflat. Internationale Revue der gesamten Hydrobiologie und Hydrographie 55: 169-195.

BATMAGLIA, B. \& VOLKMANN-ROCCO, B. 1973: Geographic and reproductive isolation in the marine harpacticoid copepod Tisbe. Marine Biology 19: 156-160.

BAYLY, I.A.E. 1970: Further studies on some saline lakes of south-east Australia. Australian Journal of Marine and Freshwater Research 21: 117-130.

BAYLY, I.A.E. \& WILLIAMS, W.D. 1966: Chemical and biological studies on some saline lakes in south-east Australia. Australian Journal of Marine and Freshwater Research 17: $177-228$.

BETOUHIM-EL, T. \& KAHAN, D. 1972: Tisbe pori n.sp. (Copepoda: Harpacticoida) from the Mediterranean coast of Israel and its cultivation in the laboratory. Marine Biology 16: 201-209.

BODIN, P. 1972a: Copépodes Harpacticoides marins des environs de La Rochelle. 2. Espèces de la zone intertidale d'Yves. T'ethys 3: 411-433. 
1972b: Copépodes Harpacticoides marins des environs de La Rochelle. 3. Espèces de la zone intertidale de Fouras-Nord. Tethys 3: 841-863.

1972c: Copépodes Harpacticoides marins des environs de Ia Rochelle. 4. Espèces de la zone intertidale des Nauteries. Tethys 4: 651-682.

BOZIC, B. 1960: Le genre Tigriopus Norman (Copepodes Harpacticoides) et ses formes européenes. Recherches morphologiques et experimentales. Archives de Zoologie Expérimentale et Générale 98: 167-269.

BRADFORD, J.M. 1972: Systematics and ecology of New Zealand Central East Coast plankton sampled at Kaikoura. New Zealand Oceanographic Institute Memoir No. 54: $89 \mathrm{pp}$.

BRESCIANI, J. 1960: Some features of the larval development of Stenhelia (Delavalia) palustris Brady, 1868 (Copepoda Harpacticoida). Dansk naturhistorisk forening Videnskabelige meddelelser 123: 237-247.

BRODIE, J.W. 1960: Coastal surface currents around New Zealand. N.Z. Journal of Geology and Geophysics 3: 235-252.

COULI, B.C. \& VERNBERG, W.B. 1975: Reproductive periodicity of meiobenthic copepods: Seasonal or continuous? Marine Biology 32: 289-293.

COULI, B.C. \& DUDLEY, B.W. 1976: Delayed naupliar development of meiobenthic copepods. Biological Bulletin, Woods Hole 150: 38-46.

DINET, A. 1972: Reproduction, développement et croissance de Bulbamphiascus imus (Brady) et Halectinosoma herdmani (T. \& A. Scott) Copepoda, Harpacticoida. Tethys 4: 437-444.

FINCHAM, A.A. 1974: Rhythmic swimming of the isopod Exosphaeroma obtusum (Dana). N.Z. Journal of Marine and Freshwater Research 8: $655-6 \overline{62}$.

FLAWS, D.E. 1975: Aspects of the Biology of Mussels in the Cook Strait Area. Unpublished Ph.D. thesis, Zoology Department, Victoria University of Wellington, New Zealand: $219 \mathrm{pp}$.

FRAZER, J.H. 1936: The occurrence, ecology and life history of Tigriopus fulvus (Fischer). Journal of the Marine Biological Association of the United Kingdom 20: $523-530$.

GOVINDANKUTTY, A.G. \& NAIR, N.B. 1972: Observations on the breeding periods of certain interstitial nematodes, gastrotrichs and copepods of the south-west coast of India. Journal of the Marine Biological Association of India 14: 402-406. 
GRICE, G.D. \& GIBSON, V.R. 1975: Occurrence, viability and significance of resting eggs of the calanoid copepod Labidocera aestiva. Marine Biology 31: 335-337.

HAMOND, R. 1973a: The harpacticoid copepods (Crustacea) of the saline lakes in south-east Australia, with special reference to the Laophontidae. Records of the Australian Museum 28: 393-420.

1973b: The Australian species of Robertsonia (Crustacea, Harpacticoida), with a revised key to the genus. Records of the Australian Museum 28: 421-435.

HARRIS, R.P. 1972: Reproductive activity of the interstitial copepods of a sandy beach. Journal of the Marine Biological Association of the United Kingdom 52: 507-524.

1973: Feeding, growth, reproduction and nitrogen utilization by the harpacticoid copepod, Tigriopus brevicornis. Journal of the Marine Biological Association of the United Kingdom 53: 785-800.

HEINLE, D.R. 1970: Population dynamics of exploited cultures of calanoid copepods. Helgoländer wissenschaftliche Meeresuntersuchungen $20: 360-372$.

HEIP, C. 1972: The reproductive potential of copepods in brackish water. Marine Biology 12: 219-221.

1973: Partitioning of a brackish water habitat by copepod species. Hydrobiologia 41: 189-198.

HICKS, G.R.F. (in press a): Ecological studies on marine algaldwelling Copepoda (Harpacticoida). 1. Species composition and zoogeography; contribution to total seaweed meiofauna. N.Z. Journal of Marine and Freshwater Research.

(in press b): Ecological studies on marine algaldwelling Copepoda (Harpacticoida). 2. Seasonal changes in population density; species occurrence and associations. N.Z. Journal of Marine and Freshwater Research.

HUIZINGA, H.W. 1971: Cultivation, life history and salinity tolerance of the tidepool copepod, Tigriopus californicus Baker 1912, in artificial seawater. Transactions of the Illinois Academy of Sciences 64: $230-236$.

Irô, T. 1970: The biology of a harpacticoid copepod, Tigriopus japonicus Mori. Journal of the Faculty of Science, Hokkaido University, Series VI, Zoology 17: 474-500.

1971: The biology of a harpacticoid copepod, Haxpacticus uniremis Kröyer. Journal of the Faculty of Science, Hokkaido University, Series VI, Zoology 18: 235-255. 
JANSEN, K.P. 1971: Ecological studies on intertidal New Zealand Sphaeromatidae (Isopoda: Flabellifera). Marine Biology 11: 262-285.

JOHNSON, M.W. \& OLSON, J.B. 1948: The life history and biology of a marine harpacticoid copepod, Tisbe furcata (Baird). Biological Bulletin, Woods Hole 95: $320-\overline{332}$.

LASKER, R. , WELLS, J.B.J. \& MCINTYRE, A.D. 1970: Growth, reproduction, respiration and carbon utilization of the sand-dwelling harpacticoid copepod, Asellopsis intermedia. Journal of the Marine Biological Association of the United Kingdom 50: 147-160.

MARSHALL, S.M. \& ORR, A.P. 1955: "Biology of a Marine Copepod." Oliver \& Boyd, London: 188pp.

MCINTYRE, A.D. \& MURISON, D.J. 1973: The meiofauna of a flatfish nursery ground. Journal of the Marine Biological Association of the United Kingdom 53: 93-118.

MORAITOU-APOSTOLOPOULOU, M. 1972: Sex ratio in the pelagic copepods Temora stylifera Dana and Centropages typicus Kröyer. Journal of Experimental Marine Biology and Ecology 8: 83-87.

MUUS, B.J. 1967: The fauna of Danish estuaries and lagoons: Distribution and ecology of dominating species in the shallow reaches of the mesohaline zone. Meddelelser fra Darmarks Fiskeri-Og Havundersogelser 5: 1-316.

NICHOLLS, A.G. 1935: The larval stages of Longipedia coronata Claus, L. scotti G.O. Sars, and L. minor T. \& A. Scott, with a description of the male of L. scotti. Journal of the Marine Biological Association of the United Kingdom 20: 29-45.

ROSENFIELD, D.C. \& COULL, B.C. 1974: Adult morphology and larval development of Paramphiascella fulvofasciata n.sp. (Copepoda, Harpacticoida). Cahiers de Biologie Marine 15: 295-317.

SMOL, N. \& HEIP, C. 1974: The culturing of some harpacticoid copepods from brackish water. Biologisch Jaarboek Dodonaea 42: 159-169.

SMYLY, W.J.P. 1970: Observations on rate of development, longevity and fecundity of Acanthocyclops viridis (Jurine) (Copepoda, Cyclopoida) in relation to type of prey. Crustaceana 18: $21-36$.

1973: Clutch-size in the freshwater cyclopoid copepod Cyclops strenuus abyssorum Sars in relation to thoracic volume and food. Journal of Natural History 7. $545-549$.

TAKANO, H. 197la: Breeding experiments of a marine littoral copepod Tigriopus japonicus Mori. Bulletin of the Tokai Regional Fisheries Research Laboratory, No. 64: $71-80$. 
1971b: Notes on the raising of an estuarine copepod Gladioferens imparipes Thomson. Bulletin of the Tokai Regional Fisheries Research Laboratory, No. 64: 81-88.

UHLIG, G., THIEL, H. \& GRAY, J.S. 1973: The quantitative separation of meiofauna: A comparison of methods. Helgölander wissenschaftliche Meeresuntersuchungen 25: 173-195.

VILELA, M.H. 1969: The lifecycle of Tisbe sp. (Copepoda Harpacticoida) under laboratory conditions. Lisbon. Instituto de biologia maritima. Notas e estudos 36: I-16.

VOLKMANN-ROCCO, B. 1972: The effect of delayed fertilization in some species of the genus Tisbe (Copepoda, Harpacticoida). Biological Bulletin, Woods Hole 142: 520-529.

VOLKMANN-ROCCO, B. \& FAVA, G. 1969: Two sibling species of Tisbe (Copepoda, Harpacticoida) = Tisbe reluctans and T. persimilis n.sp. Research on their morphology and population dynamics. Marine Biology 3: 159-164.

VOLKMANN-ROCCO, B. \& BATTAGLIA, B. 1972: A new case of sibling species in the genus Tisbe (Copepoda, Harpacticoida). Proceedings of the 5 th European Marine Biology Symposium, Piccin, Padova 19: 67-80.

WELLS, J.B.J. 1967: The littoral Copepoda (Crustacea) of Inhaca Island, Mozambique. Transactions of the Royal Society of Edinburgh 67: 189-358.

WIBORG, K.F. 1961: Estimations of number in the laboratory. Symposium on zooplankton production: Copenhagen, 1961, CORLETT, J.H.F. \& J. (eds.). International Council for the Exploration of the sea. Rapport 153: 74-77.

ZILLIOUX, E.J. \& GONZALEZ, J.G. 1972: Egg dormancy in a neritic calanoid copepod and its implications to overwintering in boreal waters. Proceedings of the 5 th European Marine Bjology Symposium, Piccin, Padova 19: 217-230. 


\section{PAPER 4}

SUBSTRATE PREFERENCE OF MARINE ALGAL-DWELLING COPEPODA (Harpacticoida).

pages : $189-209$ 
Substrate Preference of Marine Algal-Dwelling Copepoda (Harpacticoida).

Geoffrey R.F. Hicks

Zoology Department, Victoria University of Wellington, Private Bag, Wellington, New Zealand.

Abstract

Field observations show that some marine macro-algae harbour large numbers of harpacticoid copepods while on other species occupying similar zones of the shore the occurrence of these animals is minimal. The possibility of active substrate selection of specific algae was investigated in two species of harpacticoids (Porcellidium dilatatum Porcellidiidae; Scutellidium armatum Tisbidae) by providing them with a choice of visual and chemical stimuli. Both were strongly photopositive but neither was attracted visually to the tested algae. S. armatum was not significantly attracted chemically to a specific seaweed, which is consistent with its eurytopy in the field, whereas $\underline{P}$. dilatatum was significantly attracted to Zonaria turneriana the alga it is commonly associated with in nature. The attractive property of the seaweed was reduced and destroyed by physico-chemical treatments. The nature of the attraction is presumed to lie in the interaction between the macrophytic substrate and the surface microbial film. Attraction or repulsion by these properties determines the composition of the grazing copepod population and is a dynamic factor in the preference of one seaweed over another. 
Introduction

Substrate preferences to a range of sediment types and different microhabitats within the same sediment have been shown for a number of meiobenthic animals (see McIntyre 1969, Pollock 1971 for reviews). While some experimental work in relation to substrate selection has been conducted on sediment-dwelling harpacticoid copepods (e.g. Gray 1968, Jansson 1968), such preferences have not yet been conclusively demonstrated for seaweed-dwelling harpacticoids. Cursory observations, however, have been made by various authors on the apparent specificity of certain algal-dwelling invertebrates (e.g. Colman 1940, Wieser 1952, Sarma and Ganapati 1972).

During field studies on the ecology of seaweed inhabiting harpacticoid copepods (Hicks in press a, b, c) it was observed that a number of species of this important meiofaunal group exhibit a preference for certain seaweeds. Species renowned for their occurrence on sedimentary substrates elsewhere e.g. Amonardia perturbata Lang (Diosaccidae), Orthopsyllus linearis (Claus) (Canthocamptidae), Paralaophonte meinerti (Brady) (Laophontidae) clearly showed a localised distribution on Corallina officinalis where the habitat is characterised by high levels of deposited sediments. Other strictly phytal species showed analogous preferences for a number of algae devoid of these sediments e.g. Harpacticus pulvinatus Brady (Harpacticidae), Porcellidium dilatatum Hicks, P. erythrum Hicks (Porcellidiidae), while some species including Scutellidium armatum (Wiborg) (Tisbidae) did not exhibit any noticeable substrate selection in the field (Hicks in press, b). In some cases the preference for particular algal substrates appeared to dictate the animals' occurrence which was closely related to the zonal occurrence of the seaweeds on the shore. 
191.

The aim of the present experiments was to elucidate the type of behaviour responsible for the establishment and maintenance of any association between seaweeds and copepods. Experiments were conducted firstly to determine whether or not particular copepod species will actively select certain seaweeds, and secondly to attempt to explain the nature of the attraction mechanism. Animals were experimentally subjected to visual and chemical stimuli after removal from the algae on which they were found. The experiments were performed in daylight, so it was necessary to determine the animals' reaction to light in order to assess the influence of reduced illumination afforded by algal cover as an independent attractant for copepods.

Materials and Methods

Reaction to Light

The phototactic reaction was tested using specimens of Porcellidium dilatatum and Scutellidium armatum in a light/dark tube. The tube (Fig. 1) consisted of a $30 \mathrm{~cm}$ length of polypropylene "Novapipe", half of which had the upper section removed. The covered section was blackened internally whilst the exposed section was painted white. The tube was rotated through $180^{\circ}$ after each of 5 consecutive tests, thus obviating the possibility of directional learning.

The tube was filled with fresh seawater before each test and placed on a bench beneath two $40 \mathrm{~W}$ fluorescent lamps giving uniform illumination. Each test animal was removed from freshly obtained seaweed with a Pasteur pipette and placed at the junction of the light and dark ends of the tube (position 'a - Fig. 1). From this point the number of animals moving toward 
192.

Fig. 1. Iight/dark tube for testing phototactic reaction. a point of entry of experimental animals. 


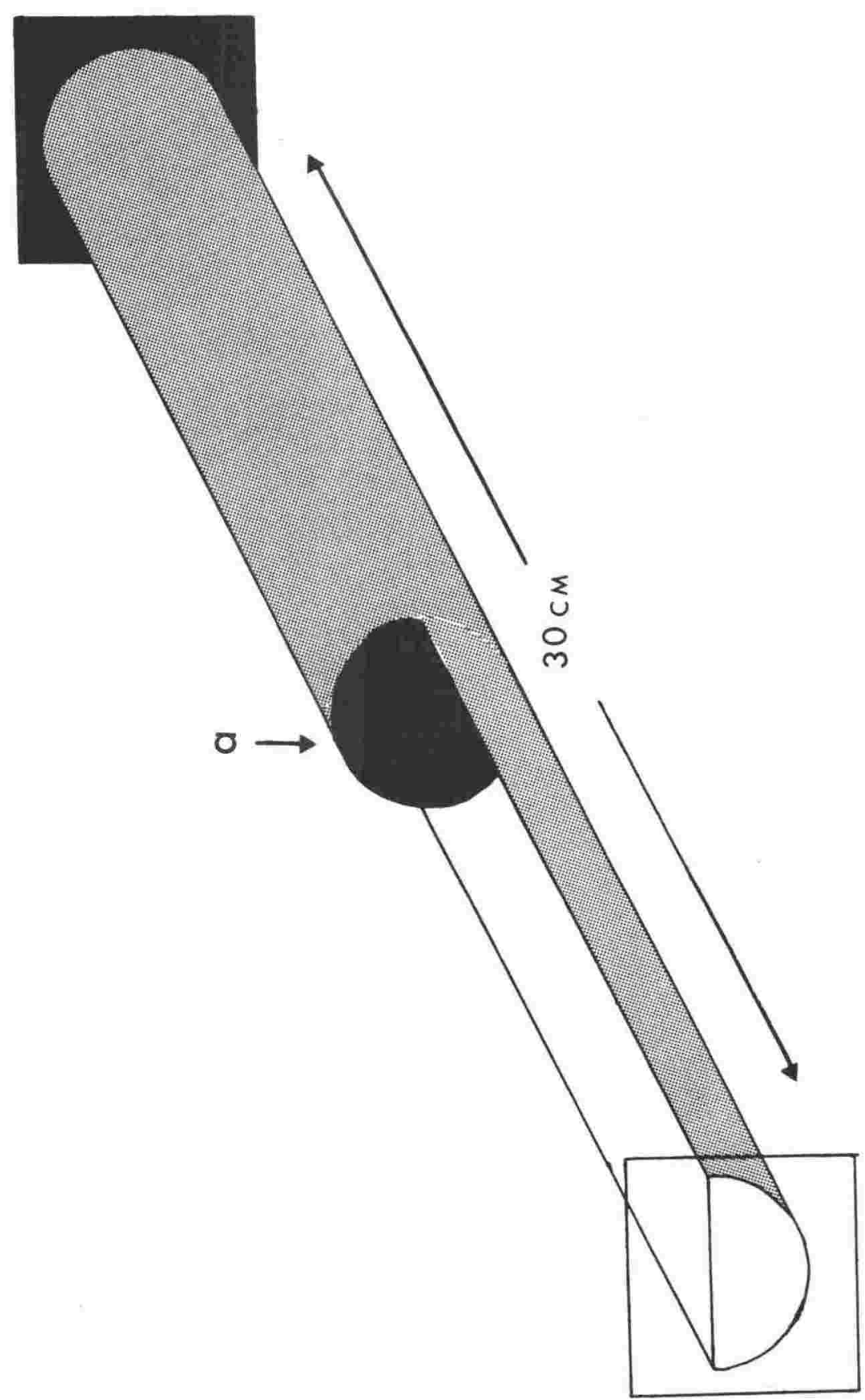


each end was recorded. A positive entry was noted when the animal moved over a distance of $4 \mathrm{cms}$ into either section. Both species, especially P. dilatatum, had a tendency to attach themselves to the walls of the apparatus and remain motionless for periods of 5-10 minutes. In such instances the animal was proded and guided back to the light/dark junction and its direction again noted.

In all experiments the probability of obtaining the observed distribution was tested for its deviation from a theoretical distribution of 50/50. Accordingly a Chi-square test was performed to find if this observed choice pattern differed significantly from that expected to occur by chance.

Reaction to Visual Stimulation

An aquariurn $(18 \times 12 \times 5 \mathrm{~cm}$ ) was blackened to reduce any extraneous influence. Six watertight transparent 'Plexiglass' partitions (three at each end - Fig. 2) were inserted and glued to ensure chemical isolation of all compartments, thus creating a static system. The floor of the 'experimental arena' (Fig. 2) was marked off in a grid of nine squares for convenient recording. Pieces of different species of seaweed were placed in each compartment. The seaweeds used in these experiments were:

$$
\begin{aligned}
& \text { Supralittoral pools - Enteromorpha intestinalis (L.) } \\
& \text { Midlittoral pools - Corallina officinalis L. } \\
& \text { Sublittoral zone - Zonaria turneriana J. Ag. } \\
& \text { - Xiphophora chondrophylla (R. Br.) Harv. } \\
& \text { var. maxima (J. Ag.) Heine } \\
& \text { - pterocladia lucida (Turn.) J. Ag. } \\
& \text { - Ecklonia radiata (C. Ag.) J. Ag. }
\end{aligned}
$$


194.

Fig. 2. Aquarium for testing the visual reaction of copepods to seaweeds. $\underline{A-F}$ sealed, watertight, transparent compartments containing different seaweeds. $1-9$ grid on floor of experimental arena. a overflow drain. 


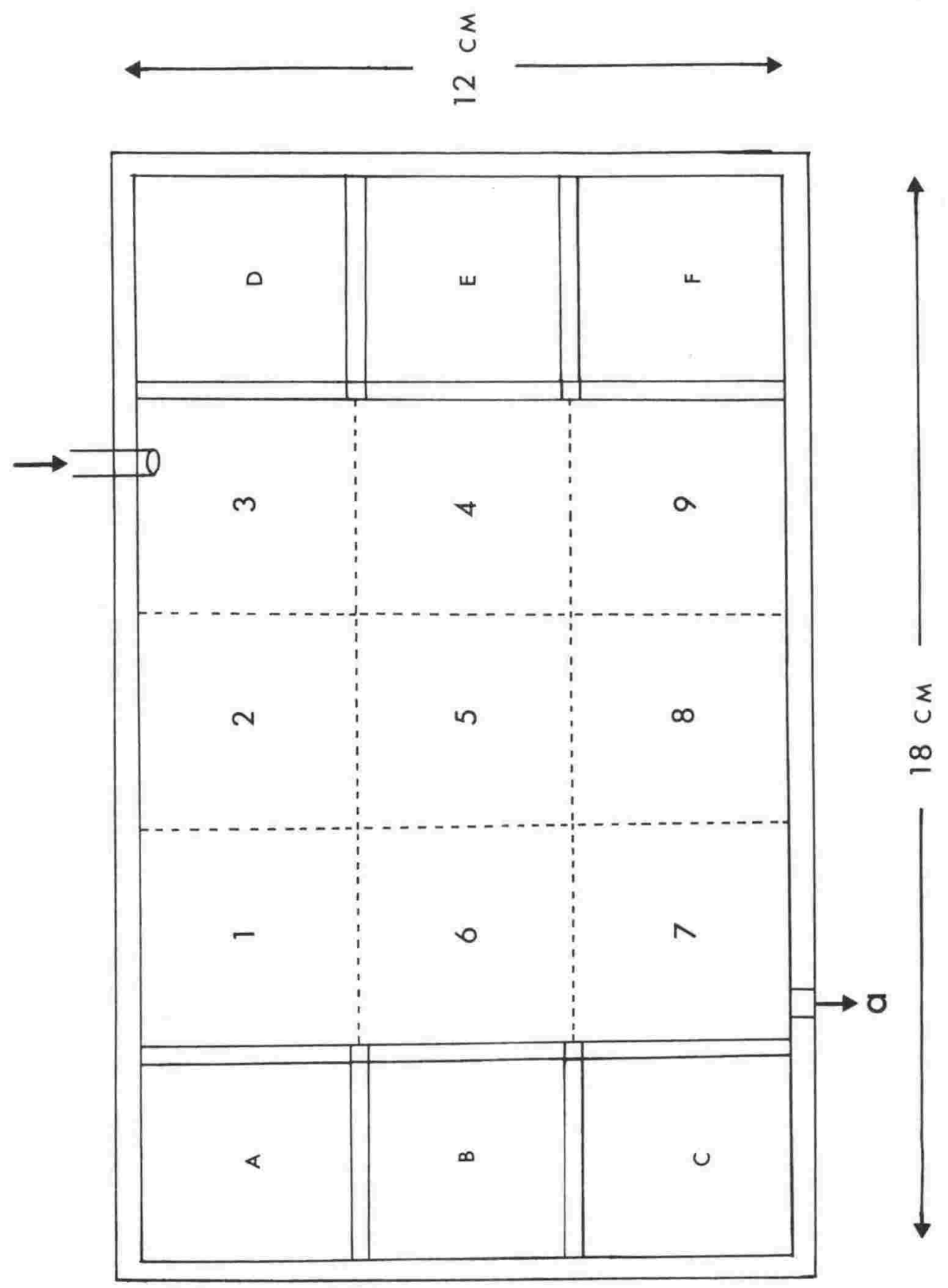


The seaweeds were freshly picked from the shore just prior to the experiments and placed in their respective compartments after removal of the experimental harpacticoid species.

The entire experimental arena was flooded with fresh seawater from a header tank which overflowed constantly through a drain 'a' (Fig. 2). After each test run the compartments and experimental arena were emptied. Replacement of seaweeds in compartments was randomised so as to limit any possible directional bias.

Ten animals each of porcellidium dilatatum and Scutellidium armatum were pipetted into choice area ' $\underline{5}^{\prime}$ (Fig. 2) at the beginning of each test which lasted one hour, the position of the copepods being recorded at 30 second intervals. A control experiment was run concurrently under the same conditions but without the seaweeds.

\section{Reaction to Chemical stimulation}

Samples of Zonaria, Xiphophora and Ecklonia were tested for a chemotactic reaction from the copepods. Seaweeds were collected from the shore and the harpacticoids sorted from the weeds as quickly as possible.

Initial tests showed that strong chemical responses towards particular algae were only observed when freshly picked weed was used for experimentation. Seaweed which had been removed from the natural environment for only a matter of hours appeared to act against any positive response (see also Frings and Frings 1965). Therefore fresh seaweed only was used in these experiments. 
Harpacticoids suspected of showing a chemotactic response to seaweeds were tested in a Y-maze, $37 \mathrm{~cm}$ long (Fig. 3). The Y-maze was linked to two water reservoirs by polypropylene tubes. One reservoir acted as a control without seaweed. The other, or experimental reservoir, held the seaweed to be tested. The outlet of each reservoir was covered with $50 \mu \mathrm{m}$ plankton gauze to prevent any larger animals from flowing down the linkage tubes and blocking them at the flow control screw (' $\underline{b}$ '). A 22 litre seawater header tank fed each reservoir. Both arms of the Y-maze received an equal flow of water from their respective reservoirs at a rate of $14 \mathrm{ml} / \mathrm{min}$. $(7 \mathrm{ml} / \mathrm{min}$. from each channel). Water flow was calibrated by introducing dye into the respective reservoir and timing its passage along the length of the Y-maze (see Blake 1960) and adjusting this flow by a screw-cock located on each delivery tube ('b-'). Flow rate was checked by collecting water from each delivery tube in a measuring cylinder.

Ten specimens of Porcellidium dilatatum or Scutellidium armatum selected at random from the collected seaweed and introduced to the choice situation at point 'a ' were offered 'untreated' seawater from the control arm and chemically 'treated' water from the experimental arm.

A new group of 10 copepods was selected at random for each experimental series. After each test the entire apparatus was washed with fresh seawater and the control and experimental arms were exchanged. The temperature of the water in the header tank and hence the reservoirs and $\mathrm{Y}$-maze was kept at approximately $20-21^{\circ} \mathrm{C}$. 
Fig. 3. Y-maze for testing chemical attraction of copepods for seaweeds. a point of entry of test animals; $\underline{b}$ flow control screw; $\underline{c}$ polypropylene connecting tubes; $\underline{d}$ plankton gauze partition; $\underline{\mathrm{H}}$ seawater header tank (22 1. capacity); $\underline{r}$ experimental and control reservoirs. Arrows indicate direction of water flow. 


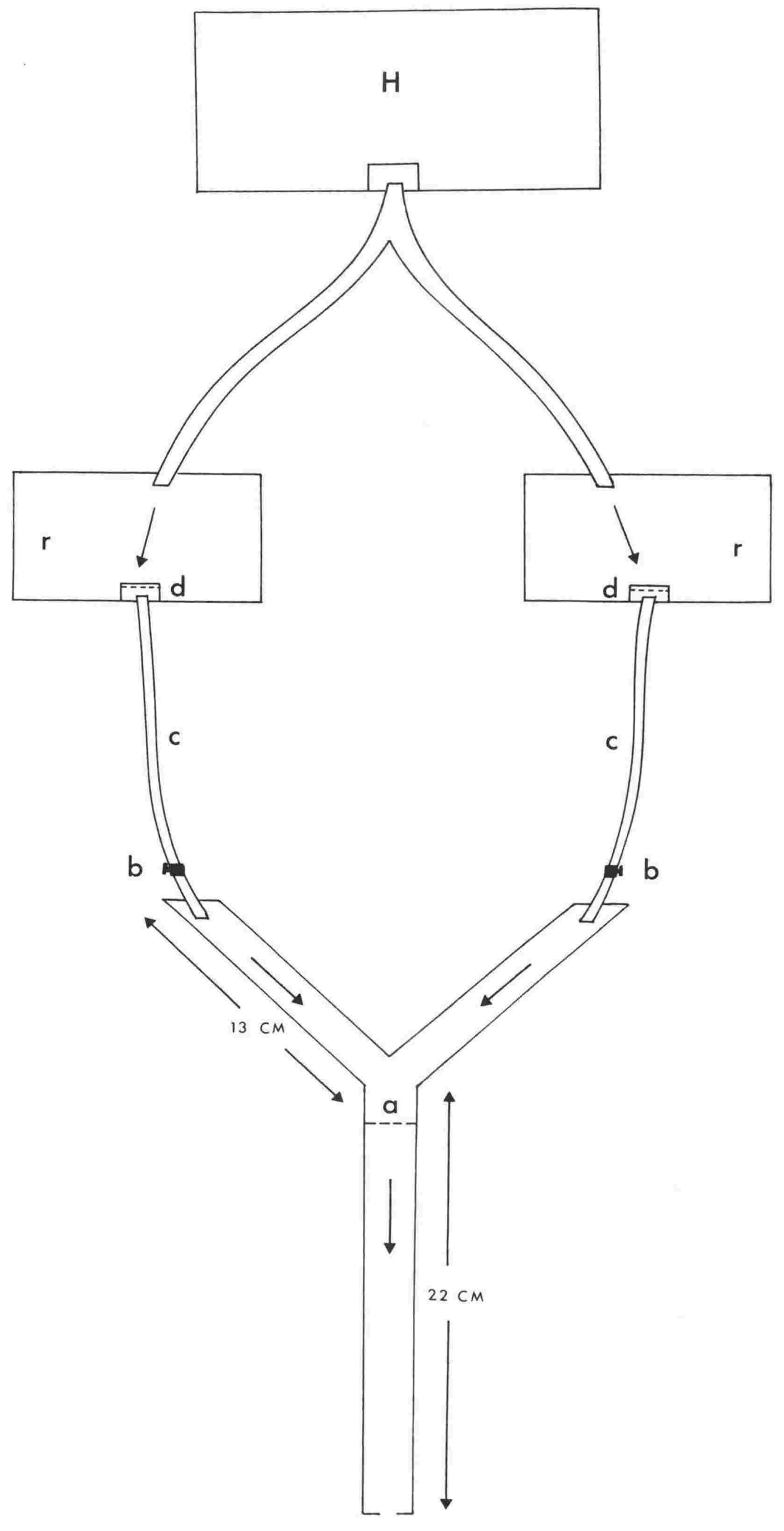


Each experiment was run for 1 hour, the position of individual animals being recorded every 30 seconds. Positions were scored positive if the copepods moved over a third the length $(5 \mathrm{~cm})$ into the experimental arm through which seaweed 'treated' water flowed and negative if into the other. If a particular individual refused to move it was lightly prodded until some form of positive or negative result was recorded. Comparison between number of copepods entering control and experimental arms was made by $\chi^{2}$ test.

The nature of any attractive substance emanating from the algae was investigated by subjecting the seaweed and its associated microflora to three treatments: boiling, soaking in distilled water and rinsing in formalin. P. dilatatum was introduced into a Y-maze with a third choice arm; one arm supplied water from a reservoir which held physically or chemically 'treated' seaweed e.g. by rinsing in formalin, the middle arm held freshly picked 'untreated' seaweed while the third arm contained no weed and acted as a control.

\section{Results}

Reaction to Light

It can be seen from Table 1 that both $\underline{P}$. dilatatum and $\underline{S}$. armatum exhibit a strong photopositive reaction $(\mathrm{P}>0.005)$, clearly prefering the uncovered end of the tube. Further laboratory observations indicate that both these species demonstrate photopositive behaviour whenever they are removed from seaweed or in the presence of stale seaweed which has been in the laboratory for some hours. 

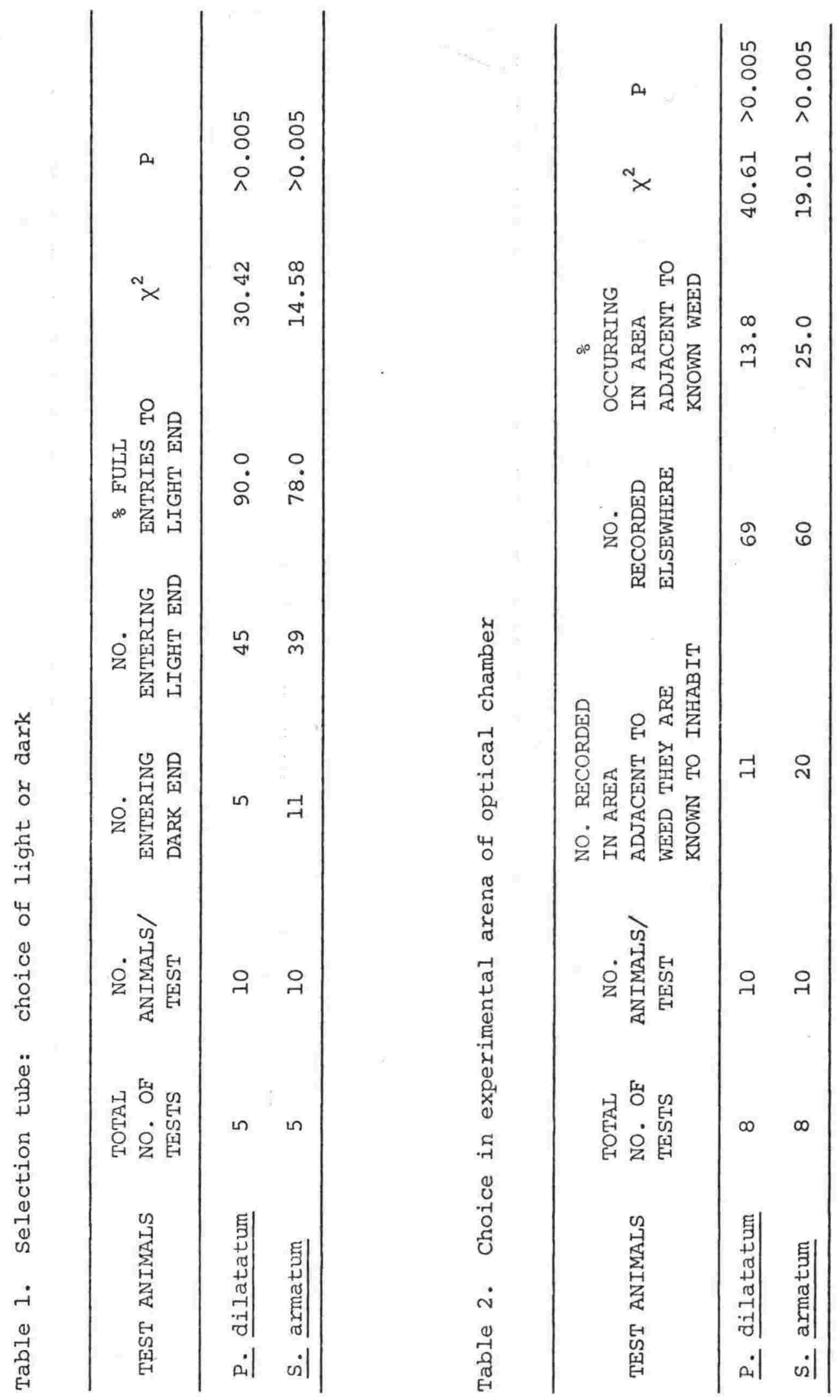
Reaction to Visual stimulation

In all the tests the distribution of copepods within the experimental arena was random, as shown for $\underline{P}$. dilatatum in Fig. 4. Scutellidium armatum spent only $25 \%$ of the experimental period adjacent to the weed it is more comnonly found associated with on the shore. The harpacticoids tested were clearly not attracted optically $(P>0.005)$ to the seaweeds they are known to commonly occur on in their natural habitat (Table 2).

Reaction to Chemical Stimulation

Table 3 gives an analysis of the responses of $\underline{S}$. armatum and $\underline{\mathrm{P}}$. dilatatum to three tested seaweeds in the Y-maze. Fewer individuals of $\mathrm{P}$. dilatatum entered the control arm than the experimental arm of the apparatus. Clearly, $\underline{P}$. dilatatum has the ability to choose between 'treated' and 'untreated' seawater $\left(x^{2}=6.61 ; \quad P \simeq 0.01\right)$, which indicates a chemical attraction of this species to zonaria. The results for Xiphophora and Ecklonia were not statistically significant, as the animals showed random selection of the arms of the apparatus indicating the lack of a similar attractive substance emanating from these algae.

S. armatum was not significantly attracted to any of the algae tested.

Effects of Seaweed Treatment

The cumulative results in Table 4 show that the chemoattractive properties of Zonaria to $\underline{\mathrm{P}}$. dilatatum demonstrated in Table 3, can be destroyed or reduced in a way similar to the settlement reducing effect on spirorbias by physico-chemical treatment of the fucoid substrate (see Knight-Jones et al. 1971). 
201 .

Fig. 4. Distribution of Porcellidium dilatatum in experimental arena of visual apparatus as shown in Fig. 2. Histograms represent the mean of 5 tests. (a) experimental distribution; (b) control distribution. 

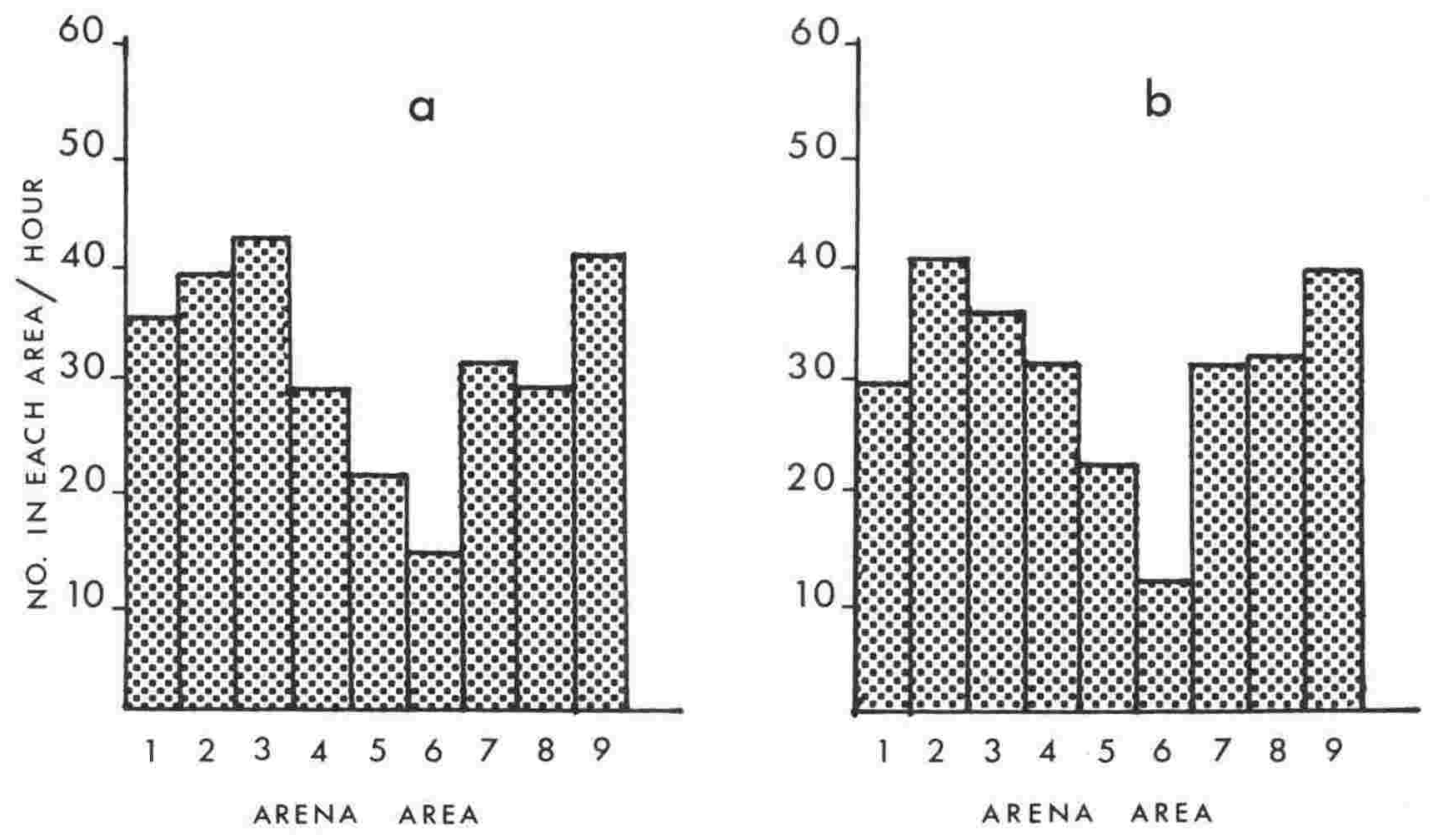


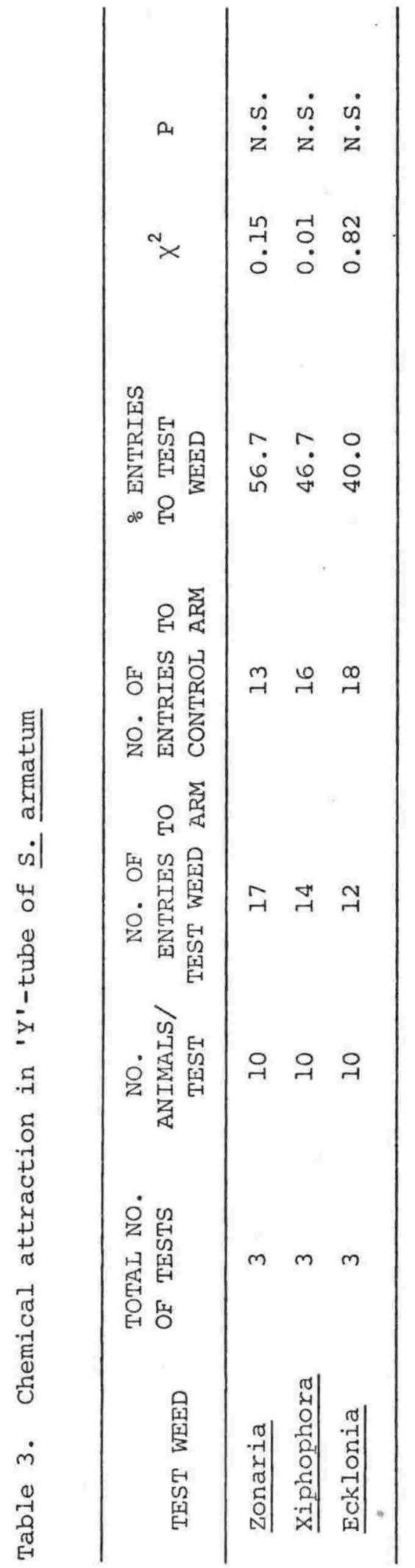

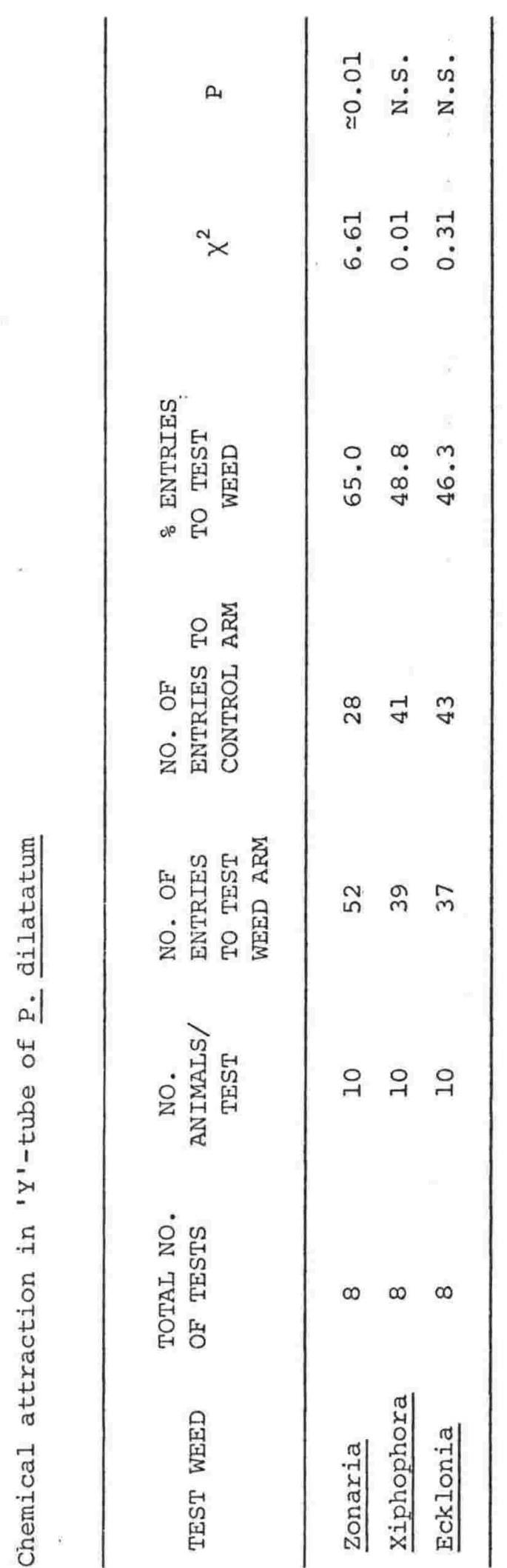


$203^{\prime}$.

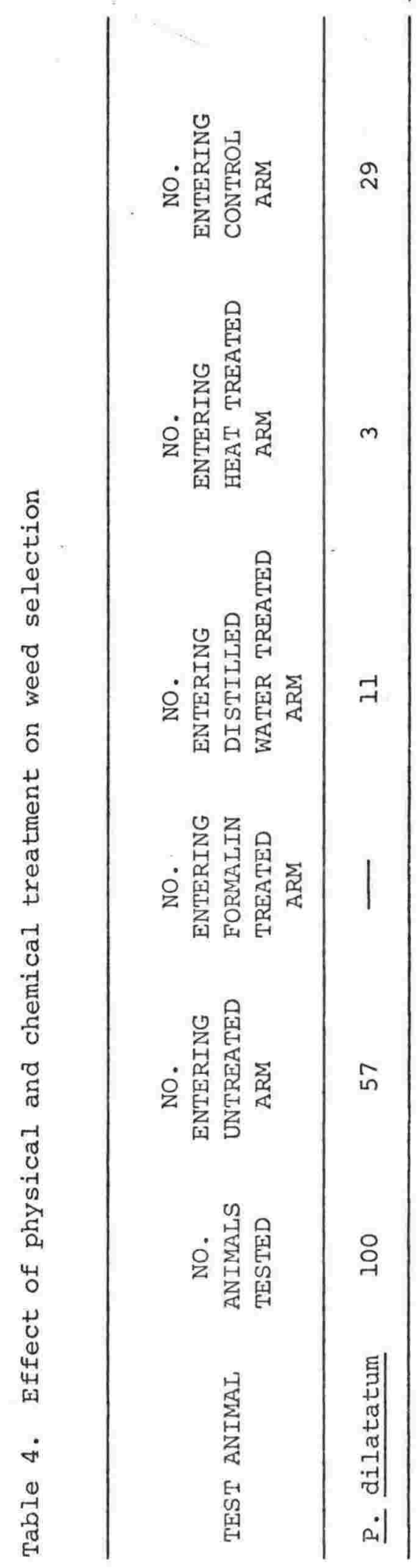


In this present experiment only $14 \%$ of the animals tested showed positive entries into the experimental arm of the apparatus offering water from algae which had been detrimentally treated. Submission of algae to any unnatural conditions, therefore, results in the alteration of a surface normaliy attractive to sessile and mobile fauna.

\section{Discussion}

The present experimental data appear to indicate the existence of a mainly chemical mechanism which is responsible for the establishment and maintenance of the association between some algal-dwelling harpacticoids and their seaweed substrate. The strong positive reaction to light (Table 1) indicates that these animals are not attracted to the reduced illumination amongst seaweeds; rather that they are broadly attracted to the brighter light conditions of shallow waters. Since no visual reaction to seaweeds is demonstrated (Table 2), the most logical stimulation remaining is chemical. In the case of $\underline{P}$. dilatatum a moderate chemoattractive response is elicited to Zonaria for which it showed a clear statistically significant preference compared with Xiphophora and Ecklonia. On the other hand Scutellidium armatum, the only other seaweeddwelling harpacticoid dealt with in the $\mathrm{Y}$-maze does not show a statistically significant attraction for any algae used in the experiments. This species is without a clear preference for a particular seaweed in the natural habitat (Hicks in press b). 


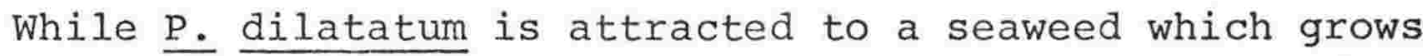
mainly on near-surface rock faces (1-2m depth), (Hicks in press a), it is conceivable that the positive light response demonstrated by this copepod could be of benefit to a dislodged or actively swimming animal (see Hauspie and Polk 1973). Isolated clumps of Zonaria can also be found in deeper water (8-10m, Hicks in press a) harbouring the same faunal composition. This suggests that the chemoattractive property of this weed is more important than any response involving light or vision. Also, detached 'benthic drift' Zonaria recovered from $25 \mathrm{~m}$ depth supports an 'atypical' faunal composition with very low numbers of $\underline{p}$. dilatatum compared with that found on attached healthy plants from shallow water. Presumably slow decay and autolysis of the drift weed biochemically alters the seaweed surface rendering it unattractive to its normal surface flora and fauna. An increased number of nematodes and larger carnivores e.g. polychaetes, caprellid amphipods, than normally exists on attached Zonaria, indicates that the ecostructure of the seaweed association has altered. The breakdown of attraction, therefore, can occur naturally by the removal of the alga from its optimal growing location or may be artificially induced e.g. heating, soaking in preservative (Table 4). This observation confirms my earlier statement that only fresh Zonaria has the attractive property. The longer the seaweed is out of its natural zone the greater the reduction in attraction to the copepods.

The origin of the actual attractant to particular copepods lies either in the properties of the alga itself or in its 'microbial film' (Meadows 1964, Gray and Johnson 1970). The presence of particular secondary algal substances in various taxonomic groups of algae (e.g. phaeophyte tannins, terpenoid 
fractions etc) have been shown to affect detrimentally the activity of surface-dwelling algal bacteria (Sieburth 1968, Bland and Brock 1973) which in turn may result in the repulsion or inhibition of settlement of many invertebrates (Conover and Sieburth 1966, Ryland 1974, Langlois 1975). Further, since algal-dwelling harpacticoids are known to feed on surface diatoms (Lang 1948, Jansson 1975) and coupled with the recently recognized importance of bacteria as a food source for many benthic harpacticoids (e.g. Gray 1968, Jansson 1968, McIntyre et al. 1970), it is conceivable that the attracting factor demonstrated in the present experiments may be in the bacteria/diatom surface film which is in turn related to the surface properties of the seaweed substrate. In support of this, Gray (1968) has reported a significant attraction of a psammic harpacticoid to a substrate containing trophically important bacteria, some of which (viz. the pseudomonads) also occur in large densities on seaweeds (Laycock 1974).

The site of detection of soluble substances could be the aesthetascs on the antennules (Lang 1948, Fahrenbach 1962) or integumental sensillae (Dudley 1972, Fleminger 1973). The stimulation of such structures will lead to the ultimate attraction of the animal to a specific substrate.

\section{ACKNOWLEDGEMENTS}

My special thanks are due to Mr George H. Grainger of the Victoria University Marine Laboratory, Island Bay, for the construction of the various apparatus. 
I am indebted to Dr Janet M. Bradford (N.Z. Oceanographic Institute), Dr Anthony A. Fincham (British Museum of Natural History), Dr Robert G. Wear and Professor John B.J. Wells (Zoology Department, Victoria University of Wellington) for valuable advice about experimental procedures and for their assistance in the preparation of the manuscript. This paper formed part of a Ph.D. thesis presented at Victoria University of Wellington; the first year of the study was conducted during tenure of a N.Z. Postgraduate Research Scholarship from the University Grants Committee.

\section{Literature Cited}

Blake, J.W.: Oxygen consumption of bivalve prey and their attractiveness to the gastropod Urosalpinx cinerea. Limnol. Oceanogr. 5 , 273-280 (1960).

Bland, J.A. and T.D. Brock: The marine bacterium Leucothrix mucor as an algal epiphyte. Mar. Biol. $\underline{23}, 283-292$

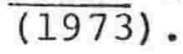

Colman, J.S.: On the faunas inhabiting intertidal seaweeds. J. mar. biol. Ass. U.K. 24, 129-183 (1940).

Conover, J.T. and J.M. Sieburth: Effect of tannins excreted from Phaeophyta on plankton and animal survival in tidepools. In: Proceedings of the First International Seaweed Symposium, pp 99-100. Ed. by E.G. Young and J.L. McLachian. New York: Pergamon Press 1966.

Dudley, P.L.: The fine structure of a cephalic sensory receptor in the copepod Doropygus seclusus Illg (Crustacea: Copepoda: Notodelphyidae). J. Morph. 138, 407-432 (1972).

Fahrenbach, W.H.: The biology of a harpacticoid copepod. La Cellule $\underline{62}$, 303-376 (1962).

Fleminger, A.: Pattern, number, variability, and taxonomic significance of integumental organs (sensilla and glandular pores) in the genus Eucalanus (Copepoda, Calanoida). Fishery Bull. Fish Wildl. Serv. U.S. 71, 965-1010 (1973).

Frings, H. and C. Frings: Chemosensory bases of food-finding and feeding in Aplysia juliana (Mollusca, Opisthobranchia). Biol. Bull. mar. biol. Lab, Woods Hole 128, 211-217 (1965). 
Gray, J.S.: An experimental approach to the ecology of the harpacticid Leptastacus constrictus Lang. J. exp. mar. Biol. Ecol. $\underline{2}, 278-292(\overline{1968)}$.

Gray, J.S. and R.M. Johnson: Bacteria of a sandy beach as an ecological factor affecting the interstitial gastrotrich Turbanella hyalina Schultze. J. exp. mar.

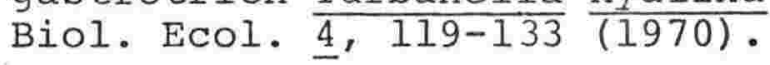

Hauspie, R. and $\mathrm{Ph}$. Polk: Swimming behaviour patterns in certain benthic harpacticoids (Copepoda). Crustaceana 25, 95-103 (1973).

Hicks, G.R.F. a: Ecological studies on marine algal-dwelling Copepoda (Harpacticoida). 1. Species composition and zoogeography; contribution to total seaweed meiofauna. N.Z. Jl mar. Freshwat. Res. (in press).

b: Ecological studies on marine algal-dwelling Copepoda (Harpacticoida). 2. Seasonal changes in population density; species occurrence and associations. N.Z. Jl mar. Freshwat. Res. (in press).

\section{c: Ecological studies on marine algal-dwelling}

Copepoda (Harpacticoida). 3. Breeding activity. N.z. Jl mar. Freshwat. Res. (in press).

Jansson, A-M.: Systems analysis and simulation of the green algal belt (Cladophora) in the Baltic. Merentutkimuslait. Julk./Havsforskningsinst. Skr. No. 239, 240-247 (1975).

Jansson, B-O.: Quantitative and experimental studies of the interstitial fauna in four Swedish sandy beaches. Ophelia $\underline{5}, 1-71$ (1968).

Knight-Jones, E.W., J.H. Bailey and M.J. Isaac: Choice of algae by larvae of Spirorbis, particularly of Spirorbis spirorbis. proc. 4th Europ. mar. biol. Symp. pp 89-104 (1971).

Lang, K.: "Monographie der Harpacticiden". Lund, Hakan Ohlsson. $1683 \mathrm{pp}$ (1948).

Langlois, G.A.: Effect of algal exudates on substratum selection by motile telotrochs of the marine peritrich ciliate Vorticella marina. J. Protozool. 22, 115-123 (1975).

Laycock, R.A.: The detrital food chain based on seaweeds. 1. Bacteria associated with the surface of Laminaria fronds. Mar. Biol. 25, 223-231 (1974).

McIntyre, A.D.: Ecology of marine meiobenthos. Biol. Rev. 44, 245-290 (1969).

McIntyre, A.D., A.L.S. Munro and J.H. Steele: Energy flow in a sand ecosystem. In: Marine Food Chains, pp 19-31. Ed. by J.H. Steele. Edinburgh: Oliver and Boyd 1970. 
Meadows, P.S.: Experiments on substrate selection by Corophium species: films and bacteria on sand particles. J. exp. Biol. 41, 499-511 (1964).

Pollock, L.W.: Ecology of intertidal meiobenthos. In: Proceedings of the First International Conference on Meiofauna, pp 141-148. Ed. by N.C. Hulings. Smithson. Contr. Zool. No. 761971.

Ryland, J.S.: Observations on some epibionts of Gulf-weed, Sargassum natans (L.) Meyen. J. exp. mar. Biol. Ecol. 14, 17-25 (1974).

Sarma, A.L.N. and P.N. Ganapati: Faunal associations of algae in the intertidal region of Visakhapatnam. Proc. Nat. Sci. Acad. India, Part B 38, 380-396 (1972).

Sieburth, J.M.: The influence of algal antibiosis on the ecology of marine microorganisms. Adv. Microbiol. Sea 1 , 63-94 (1968).

Wieser, W.: Investigations on the microfauna inhabiting seaweeds on rocky coasts. IV. Studies on the vertical distribution of the fauna inhabiting seaweeds below the Plymouth Laboratory. J. mar. biol. Ass. U.K. 31, 145-174 (1952): 
APPENDIX

REPRINT

"Neopeltopsis pectinipes, a new genus and species of seaweed-dwelling copepod (Harpacticoida: Peltidiidae) from Wellington, New Zealand." N.Z. Journal of Marine and Freshwater Research 10: 363-370 (1976).

This paper was completed to provide a valid taxonomic name for use in this thesis and in the subsequent papers. It is herewith included in support of the thesis. 
N.Z. Journal of Marine and Freshwater Research 10 (2) : 363-70. June 1976

\title{
NEOPELTOPSIS PECTINIPES, A NEW GENUS AND SPECIES OF SEAWEED-DWELLING COPEPOD (HARPACTICOIDA: PELTIDIIDAE) FROM WELLINGTON, NEW ZEALAND
}

\author{
GEOFFREY R. F. HICKS \\ Zoology Department, Victoria University of Wellington, \\ Private Bag, Wellington, New Zealand
}

\section{ABSTRACT}

Neopeltopsis pectinipes gen. et sp. nov. is described and figured from sublittoral marine algae at Wellington, New Zealand; the genus is an addition to the Peltidiidae Sars. The genus is compared with the other genera of the family, and a revised key is given to the genera of the Peltidiidae.

\section{INTRODUCTION}

During a sampling programme to study the population structure and ecology of the seaweed-dwelling Copepoda (Harpacticoida) at Island Bay, Wellington, New Zealand, a large number of new species were encountered. Among them was a commonly occurring form belonging to the Peltidiidae which I was not able to place within any of the existing genera.

The family Peltidiidae Sars contains seven genera (Lang 1948; Bodin 1967, 1971), members of which are common inhabitants of marine sediments and algae.

\section{SYSTEMATICS}

Family Peltididdae Sars, 1904

Neopeltopsis gen. nov.

DiAGNOSIS: Body flattened with a simple skeletal pattern, not as well developed as in Peltidium Philippi or Parapeltidium A. Scott; rostrum broad, prominent; antennule 8-segmented in the female, 9 in the male; antennal exopod rudimentary, 1-segmented and bearing 2 setae; Pl endopod 2-segmented, exopod segment 3 bearing 4 large flattened comb-shaped setae; endopods and exopods of P2-P4 3-segmented, P5 2-segmented, exopod smaller than bascoendopod, in the form of a triangle with slightly curved sides; urosome broadly ovate, slightly expanded laterally but extending posteriorly so as to almost surround the caudal rami; caudal rami rectangular, posteriorly truncated, length to width ratio of nearly $3: 1$ in the female, but only about $3: 2$ in the male; urosome-caudal rami complex analogous to that of the genus Porcellidium (Porcellidiidae Sars).

Received 17 December 1975. 
The above defintition coincides with that of its only known and type species, and must, therefore, be considered tentative.

Neopeltopsis pectinipes sp. nov.

(Figs 1-3)

FEMALE (Fig. 1A) : Total length $1.04 \mathrm{~mm}$; length to width ratio is $1.8: 1.0$; body flattened, simple pattern of chitinous thickening, not as well developed as in Peltidium Philippi or Parapeltidium A. Scott.

Rostrum (Fig. 1A) broad, prominent.

Urosome (Fig. 1c) broadly ovate, slightly expanded laterally,' with 3 lateral clefts on each side marking the fusion of the abdominal somites; postero-lateral wings of urosome extensive and closely surrounding caudal rami.

Caudal rami (Fig. 2G) rectangular with parallel sides, posteriorly truncated and not extending beyond posterior border of urosome, length to width ratio of $2.9: 1.0$, each ramus bearing 4 dorsal setae, 3 terminal setae, and distal surface spinules. The urosome-caudal rami complex rather like Porcellidium.

Antennule (Fig. 3A) 8-segmented with aesthetascs on segments 4 and 8; first and second segments with groups. of spinules.

Anenna (Fig. 2^) coxa small, bare; basis rectangular and bearing exopod. Endopod segment 1 longer than basis, bearing a single naked marginal seta. Endopod segment 2 with 4 subterminal geniculate setae, 2 large spines and 2 expanded saw-like terminal setae. Exopod rudimentary, 1-segmented and bearing 2 setae.

Mandibular praccoxa (Fig. 2B) elongate and narrow, cutting edge small; coxa-basis narrow and bears a single seta; endopod has 1 proximal and 3 terminal setae; exopod with 3 terminal setae; all setae smooth.

Maxiliule (Fig. 2c) arthrite of praecoxa with 10 setae distally; coxa small with 3 apical setae; basis with 4 terminal setae, one of which is large and spiniform, and 2 subterminal setae; endopod represented by 3 setae, one of which is reduced; exopod bearing 3 terminal setae.

Maxilla (Fig. 2D) syncoxa bearing 3 endites; proximal endite with 4, other endites with 2 and 3 terminal setae respectively; basis bearing one spiniform and 2 naked setae; endopod represented by 2 small setae.

Maxilliped (Fig. 2E) subchelate; coxa larger than basis; basis bears a small plumose seta; endopod expanded, ovoid, bearing a strong curved spine and a shorter stout seta with a cushion of tiny spinules; a group of spines occurs proximally on the outer margin of the endopod palm.

PI (Fig. 3c) coxa longer and wider than basis; basis bears 2 setae, one of which is placed at the base of the endopod; exopod segments 1 and 2 each with a single naked outer seta, segment 2 also with an inner distal spinulated seta: exopod segment 3 small and indistinctly separated from segment 2 , bearing 4 broadly flattened comb-shaped setae; endopod 2-segmented and bearing 8 setae on the distal segment.

P2, P3, and P4 all with 3-segmented exopods and endopods; seta and spine formulae are as follows:

$$
\begin{array}{lllll} 
& & & \text { Endopod } & \text { Exopod } \\
\text { P2 (Fig. 3D) } & \ldots & \ldots . . . & 0.1 .120 & 0.1 .222 \\
\text { P3 (Fig. 3E) } & \ldots & \ldots . . & 1.1 .220 & 0.1 .322 \\
\text { P4 (Fig. 3F) } & \ldots & \ldots . . & 1.1 .220 & 0.1 .322
\end{array}
$$

PS (Fig. 2F) baseoendopod over twice the length of exopod, bearing 4 setae on the inner edge, the most distal of which is strongly spiniform, and one small terminal seta on the distal outer corner; exopod slightly curved, in the form of a triangle, with 6 setae on the outer margin, the most distal of which is spiniform. 

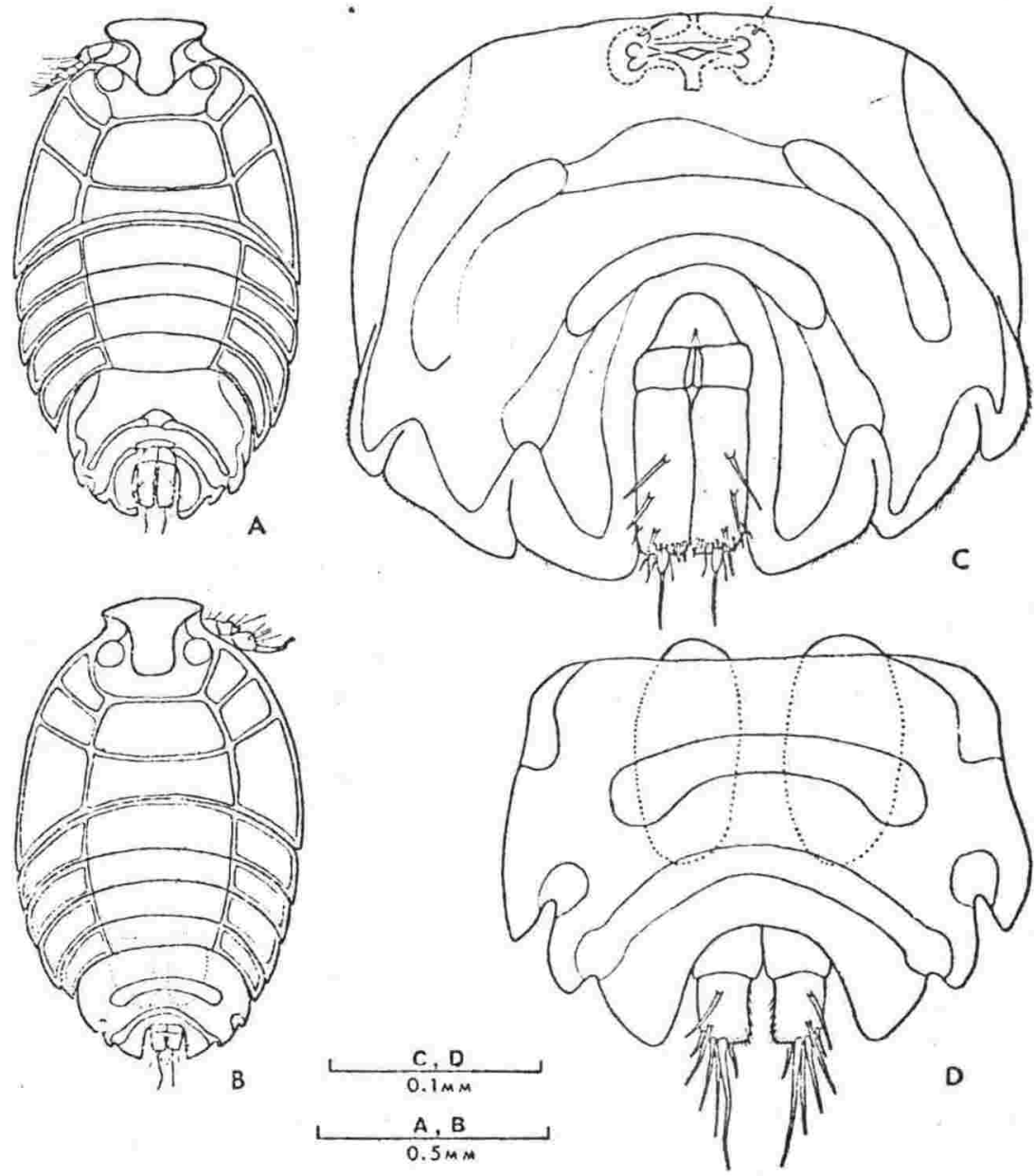

FIG. 1-Neopeltopsis pectinipes gen. et sp. nov.: (A) $q$ dorsal view; (B) of dorsal vieiv; (C) f urosome dorsal view; (D) ô urosome dorsal view.

Colour in the live animal is variably grey-gold, some with the thoracic epimera tinged with violet-blue.

MALE (Fig. 1B): Total length $0.98 \mathrm{~mm}$; body generally shaped like female.

Rostrum (Fig. 1B) as in female.

Urosome (Fig. 1D) broadly ovate, with 2 distinct lateral notches marking the fusion of the abdominal somites.

Caudal rami (Fig. 21) rectangular and not extending past the posterior border of the urosome; length to greatest width ratio of $1.5: 1.0$, each ramus bears 4 dorsal setae and 3 terminal setae, the middle of which is longest; spinules are present on the medial and posterior borders. 
366 N.Z. Journal of Marine \& Freshwater Research [June

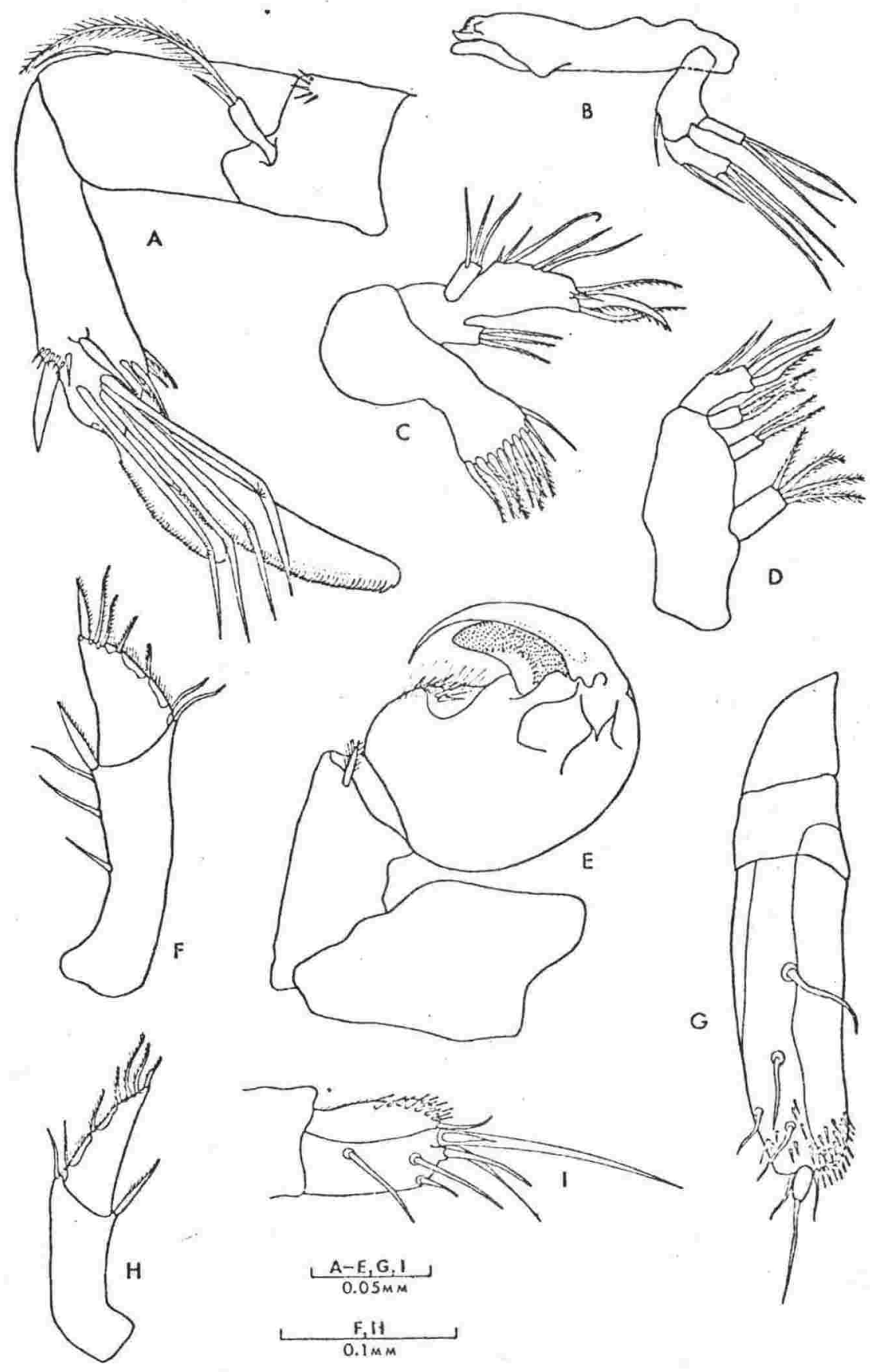

FIG. 2-Ncopeltopsis pectinipes gen. et sp. nov., $\%$ : (A) antenna; (B) mandible; (C) maxillule; (D) maxilla; (E) maxilliped; (F) P5; (C) caudal ramus; ô : (Bi) P5; (I) caudal ramus. 


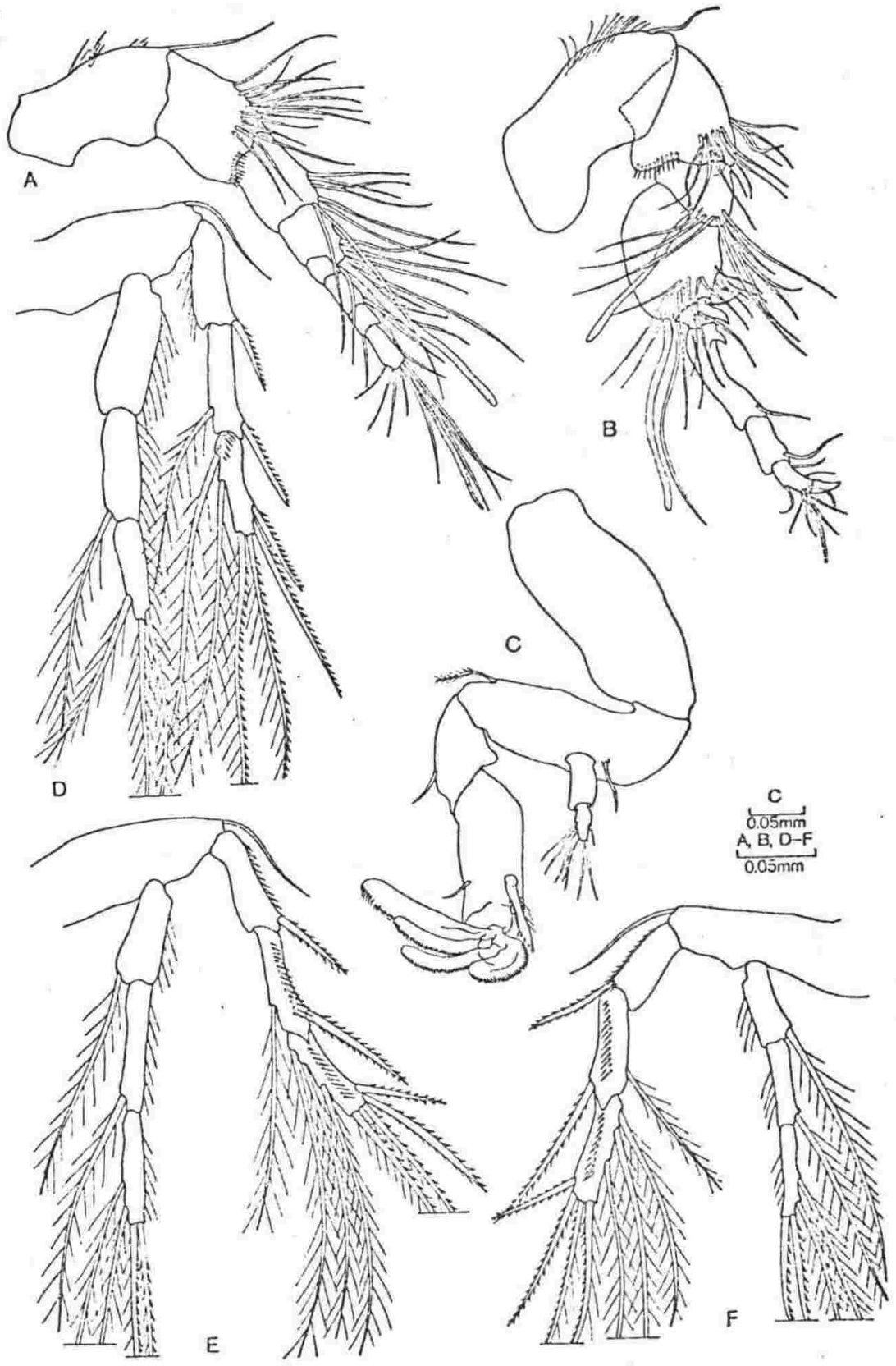

FIG. 3-Neopeltopsis pectinipes gen. et sp. nov.: (A) $\$$ antennule; (B) $\delta$ antennule; (C) \& P1; (D) \& P2; (E) \& $\mathrm{P} 3$; (F) $\&$ P4. 


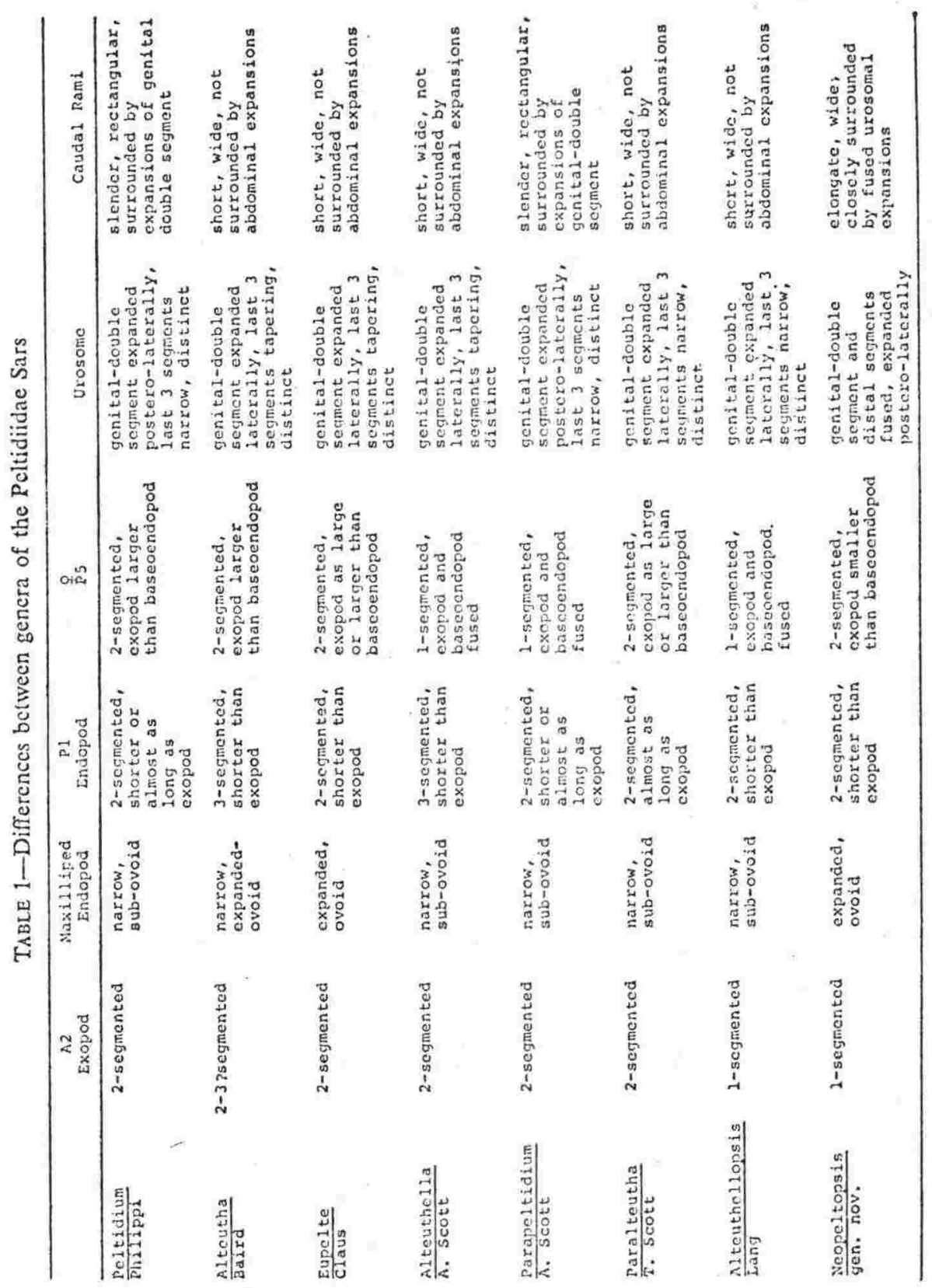


Antennule (Fig. 3B) is 9-segmented; segment 3 small, with aesthetasc; segment 4 expanded, ovate and bearing an aesthetasc; segment 5 small and bearing a distinct tooth on its margin; segment 6 elongate, narrow, and also bearing a proximal tooth; segment 8 with small aesthetasc; distal segment small, recurved.

P5 (Fig. $2 \mathrm{H}$ ) narrower than in the female; bascoendopod only slightly longer than exopod and lacking the 3 inner naked sctae present in the female; exopod as in female but more elongate and narrow; outer distal seta of the exopod not as spiniform as in the female.

Colour as in the female.

VARIABILITY: Ten specimens have been dissected. They were identical except for one female which had a setal and spine formula on the P2 endopod of 0.1 .110 on one limb; another female had 0.2 .120 on one limb of the same appendage.

HoLOTYPE: The undissected holotype female is deposited in the National Museum, Wellington, New Zealand (Nat. Mus. Z. Cr. 1998).

Paratypes: One dissected and six undissected females, one dissected male, and one undissected male, have been deposited with the National Museum, Vellington, New Zealand (Nat. Mus. Z. Cr. 1999-2001); one female and one male dissected specimens are also deposited in the British Museum (Nat. Hist.) (BM(NH) 1975.1269 and 1975.1268 respectively).

TYPE LOCALITY: Type material was collected from the red gelidiacean alga Pterocladia lucida at a depth of $6 \mathrm{~m}$ opposite the Victoria University Marine Laboratory at Island Bay, Wellington, on 30 September 1973. The species can be collected throughout the year and is sometimes also found at a similar depth on $P$. pinnata and the green 'sea rimu' Caulerpa brownii.

ETYMology: The generic name is derived from the Greek neos = new, pelta $=$ small shield, and -opsis $=$ appearance, and refers to a new genus within the Peltidiidae. The gender is masculine. The specific name is derived from the Latin pecten $=$ comb, and pes $=$ foot, and relates to the flattened comb-shaped setae on the distal exopod segment of P1.

REMARKS: Neopeltopsis is remarkable in that the majority of its characters are sufficient to place it within the Peltidiidae, but its urosomecaudal rami complex is very like that found in the Porcellidiidae Sars.

Neopeltopsis shares a number of important features with o:her peltidiid genera (Table 1), notably the 2-segmented endopod of P1, found in Peltidium, Eupelte Claus, Purapeltidium and Paralteuha T. Scott, and the combination of this feature with the unsegmented exopod of the antenna seen in Alteuthellopsis Lang. However, it is distinct in having a 2-segmented P5 with an exopod which is smaller than the baseoendopod, but more importantly the structure of the urosome and its relationship with the caudal rami resembles that found in the monotypic Porcellidiidae. The fused lateral expansions of the abdominal somites extend posteriorly to almost surround the caudal rami, as seen in a number of species of Porcellidium (see Humes \& Gelerman 1962, Hicks 1971). This feature along with a number of others (Table 1) distinguishes Neopeltopsis from Alteuthellopsis, which has a similar expanded genitaldouble segment but a small narrow abdomen bearing terminal caudal rami.

Because Neopeltopsis appears to have affinities with two well. established families, the possible discovery of further species may result in the erection of a new family. 
Key to the Peltididdae Sars

\section{Both SEXES}

Revised from Nicholls (194I) and Lang (1948)

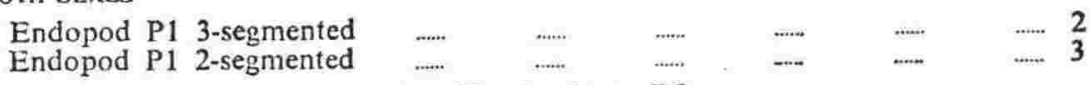

2 Distal segment exopod P1 with 1 claw; P5

1-segmented
Distal segment exopod P1 with 2 or more claws; P5 2-segmented

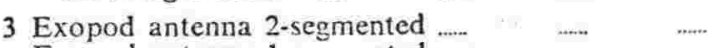

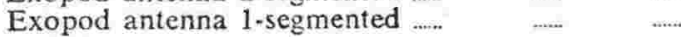

4 PS 1-segmented; abdominal segments narrow, disinct; caudal rami exposed ......

P5 2-segmented; abdominal segments expanded, fused, surrounding caudal rami

5 Caudal rami slender, rectangular

Caudal rami wide, plate-like ..... ....... …...

6 Exopod segment 1 P1 short, exopod about twice as long as endopod Exopod segment 1 P1 elongate, exopod and endo-
pod almost equal in length....

7 P5 2-segmented

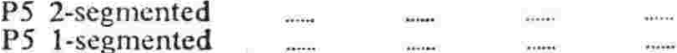

..... Alteuthella A. Scott

..... Altcutba Baird

$\begin{array}{lll}\cdots . . . & \ldots . . & 5 \\ \cdots . . . & \ldots . . & 4\end{array}$

Alteuthellopsis Lang

Neopeltopsis gen. nov.

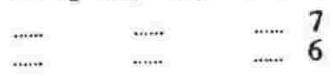

Eupelte Claus

Paralteutha T. Scott

Peltidium Philippi

Parapeltidium A. Scott

\section{ACKNOWLEDGMENTS}

I am most grateful to Dr J. M. Bradford (N.Z. Oceanographic Institute, DSIR) and Dr R. Hamond (c/o Zoology Dept., Melbourne University, Australia) for critically reading the manuscript.

\section{Literature Cited}

Bodin, P. 1967: Catalogue des nouveaux copépodes harpacticoides marins. Mémoirs du Muséum National d'Histoire Naturelle (sér. A) 50: 1-76.

1971: Catalogue des nouveaux copépodes harpacticoides marins. Additif No. 1. Tethy's 2: 881-907.

Hicks, G. R. F. 1971: Some littoral harpacticoid copepods, including five new species, from Wellington, New Zealand. N.Z. Journal of Marine and Freshwater Research 5: 86-119.

Humes, A. G. \& Gelerman, P. H. 1962: A new species of Porcellidium (Copepoda, Harpacticoida) from a sea urchin in Madagascar. Crustaceana 4: 311-19.

LANG, K. 1948: "Monographie der Harpacticiden”. Hakan Ohlsson, Lund. 1683 pp.

Nicholis, A. G. 1941: Littoral Copepoda from South Australia (1) Harpacticoida. Records of the South Australian Museum 6: 381-427. 


\section{THESIS ACKNOWLEDGEMENTS}

The task of acknowledging those individuals who have assisted morally and/or materially in the design, undertaking and final compilation of a piece of work of this magnitude is inevitably a difficult one. Firstly, I must thank the Zoology Department, Victoria University of Wellington for the provision of research facilities at the Island Bay Marine Laboratory where this study was carried out.

Dr Bob Wear has been of incalculable assistance in the planning of sampling procedures and as a source of energy and support throughout the course of this investigation. His untiring efforts in supervising my programme, coupled with his enthusiastic interest in the work made the burden of completion much lighter.

My 7 years of professional association with Dr Janet Bradford (N.Z.Oceanographic Institute) have largely been responsible for providing the inspiration and direction in my research. To her must go the initial stimulus for working on marine harpacticoids and also much of the credit in the way this thesis is organised and presented. I have much to be thankful for in her patience, eye for detail and in her charming and helpful manner.

For constructive criticism and advice on many of my taxonomic conclusions Dr Dick Hamond (zoology Dept., Melbourne University) has been of unsurpassed assistance. I look forward to continued liaison with him over systematic problems of our mutual interest. Dr Tony Fincham (formerly Post-Doctoral Fellow at Island Bay) brought insight into the difficulties of ecological field studies and spent many hours discussing the often considerable shortcomings in my logic. 
I must praise the efforts of both of my thesis overseers Professors Jack Garrick and Bob Averi11. Without their support in times of necessity I am quite sure this thesis would not have come to fruition. Colleagues and friends at the Laboratory and at the University, namely Mike Bull, Geoff Read, Lin Roberts and Graham Hardy have contributed immensely to seeing this work evolve into completion. Mr Bill Armstrong (Mathematics Dept., V.U.W.) provided much advice on sampling and analytical statistics for which I am extremely grateful; Miss Nancy Adams (National Museum, wellington) kindly corroborated my identifications of the Island Bay algae; and Mr George Grainger (resident technician at the Island Bay Marine Lab.) helped in many ways, particularly in his masterly construction of various articles of equipment used in this study. I appreciate the time and effort put in by my typist olga Vincent and by the University Multilith Dept. for reproducing the figures.

Finally, I have benefited greatly over the closing stages of this work from the illuminating discussions with our recently arrived Professor John Wells. His wealth of experience and knowledge on harpacticoid systematics and meiobenthic ecology has assisted me immeasurably, especially in his comments on the manuscripts. The feeling of frustration at being unable to continue working with John is difficult to convey.

Should I be fortunate enough to continue with marine biological research my only hope is that my workmates will be of the quality and integrity of those around me at this time. To everyone ........... Thanks!

The first year of this study was carried out under the tenure of a New Zealand University Grants Committee Postgraduate Scholarship. 